${ }_{P_{P} O_{B}}$ 


\section{PROBLEMY MONITORINGU EKSPLOATACJI SPRZĘTU I WYPOSAŻENIA W STRAŻY POŻARNEJ}

Publikacja opracowana w ramach projektu nr DOBR-BIO4/051/13087/2013 finansowanego przez Narodowe Centrum Badań i Rozwoju pod tytułem: „Opracowanie metodologii stałego nadzoru eksploatacji wybranych obszarów wyposażenia straży pożarnej w zakresie niezawodności i skuteczności działania”

Projekt realizowany przez konsorcjum w składzie:

Centrum Naukowo-Badawcze Ochrony Przeciwpożarowej im. Józefa Tuliszkowskiego - Państwowy Instytut Badawczy; CMGI Sp. z o.o; Szkoła Główna Służby Pożarniczej; MLabs Sp. z o.o.; TELDAT Sp. z o.o. Sp. k

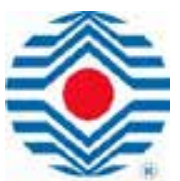

CNBOP-PIH

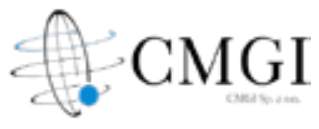

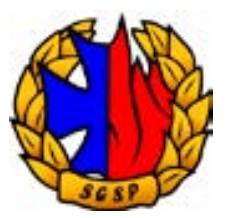

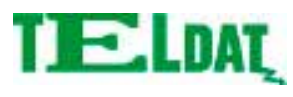

Mlatos

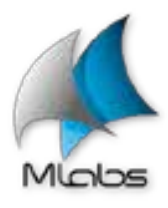




\title{
Redakcja opracowania:
}

dr inż. Jacek Roguski

\section{Recenzja:}

prof. dr hab. inż. Jan Posobiec

dr hab. inż. Marek Kubiński

dr inż. Adam Majka

\section{Korekta:}

Julia Pinkiewicz, Elżbieta Muszyńska

\section{Projekt okładki:}

Julia Pinkiewicz

Grafika na okładce:

made by Freepik.com

\section{ISBN 978-83-61520-22-1}

DOI 10.17381/2015.2

(C) Copyright by Wydawnictwo CNBOP-PIB, Józefów 2015

\author{
Skład i druk: \\ BEL Studio Sp. z o.o. \\ 01-355 Warszawa \\ ul. Powstańców Śl. 67 B \\ tel./fax (+48 22) 6659222 \\ e-mail: studio@bel.com.pl \\ księgarnia: http://www.iknt.edu.pl
}

\section{Wydawca:}

Centrum Naukowo-Badawcze Ochrony Przeciwpożarowej im. Józefa Tuliszkowskiego - Państwowy Instytut Badawczy 05-420 Józefów k/Otwocka ul. Nadwiślańska 213 www.cnbop.pl 


\section{Spis treści}

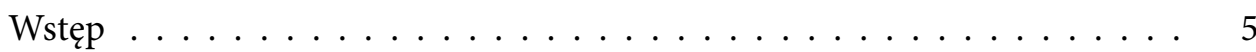

\section{Część I}

Nadzór nad eksploatacją wybranych obszarów wyposażenia straży pożarnej w zakresie niezawodności i skuteczności działania

Metodyka i kryteria wyboru obiektów do badań

Dariusz Czerwienko, Leszek Jurecki, Jacek Roguski . . . . . . . . . . . . . . .

Wymagania funkcjonalne dla systemu monitorowania i analiza niezawodności eksploatacji wybranych środków wyposażenia Państwowej Straży Pożarnej Janusz Kręcikij, Dawid Rzemek . . . . . . . . . . . . . . . . . . . . . .

Bezpieczeństwo transmisji danych w systemach monitorowania wyposażenia straży pożarnej

Łukasz Apiecionek, Rafat Motylewski, Pawet Stosik . . . . . . . . . . . . . .

Sieć sensorowa systemu pomiaru i diagnozowania pomp stosowanych w jednostkach ratowniczo-gaśniczych

Mikołaj Sobczak, Michat Pasieka, Bartosz Kukawka . . . . . . . . . . . . . .

Badanie wpływu wybranych uszkodzeń na parametry pracy motopompy pożarniczej -wyznaczenie wartości parametrów dla stanu zdatności Włodzimierz Kupicz, Pawet Ogrodnik . . . . . . . . . . . . . . . . .

Eksploatacja rękawów przeciwpowodziowych

Dorota Riegert, Zuzanna Ślosorz, Adam Majka . . . . . . . . . . . . . . . .

\section{Część II}

Nowoczesne rozwiązania ochron osobistych dla służb ratowniczych KSRG w oparciu o potrzeby użytkowników końcowych

Problemy związane z oceną ochron osobistych poddanych obciążeniu cieplnemu Tomasz Wiśniewski, Piotr Furmański, Piotr Łapka . . . . . . . . . . . . . . .

Badania ergonomiczne odzieży ochronnej z zastosowaniem manekina typu Newton

Izabella Krucińska, Ewa Skrzetuska

Badania eksploatacyjne w polu operacyjnym

Łukasz Pastuszka, Karolina Dwórska, Łukasz Rowicki, Maciej Gloger . . . . . . . . 
Wpływ konstrukcji ubrań specjalnych na parametry wydolnościowe ratownika Tomasz Węsierski, Przemystaw Kowalczyk . . . . . . . . . . . . . . . . . . . . . . 141

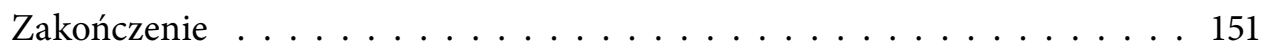

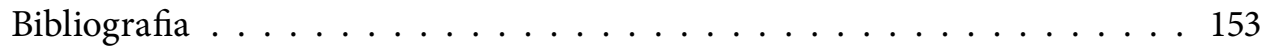

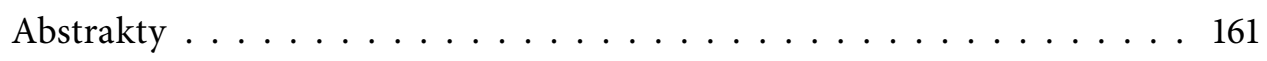

Notki biograficzne .......................... 171 


\section{WSTĘP}

Publikacja Problemy eksploatacji sprzętu i wyposażenia w straży pożarnej ma na celu zapoznanie potencjalnych użytkowników z możliwościami tworzonych rozwiązań systemowych oraz efektywnego wykorzystania wyników projektów badawczych, w których realizacji uczestniczy Centrum Naukowo-Badawcze Ochrony Przeciwpożarowej im. Józefa Tuliszkowskiego Państwowy Instytut Badawczy. $\mathrm{W}$ publikacji przedstawione zostały wyniki prac związanych $\mathrm{z}$ realizacją następujących projektów:

- DOBR BIO4/051/13087/2013 „Opracowanie metodologii stałego nadzoru eksploatacji wybranych obszarów wyposażenia straży pożarnej w zakresie niezawodności i skuteczności działania",

- 0014/R/ID1/2011/01 „Nowoczesne ochrony osobiste służb ratowniczych KSRG w oparciu o potrzeby użytkowników końcowych",

- 0013/R/ID2/2011/01 „Optymalizacja procedur, dyslokacji baz i doskonalenie rozwiązań technicznych sprzętu stosowanego przez polskie służby ratownicze w zakresie przeciwdziałania zagrożeniom naturalnym ze szczególnym uwzględnieniem powodzi (rękawy przeciwpowodziowe)",

- ROB/0011/03/001 „Opracowanie innowacyjnego systemu stanowisk do badań ochron osobistych".

$\mathrm{W}$ ujęciu definicyjnym ${ }^{1}$ eksploatacja jest zjawiskiem techniczno-ekonomicznym, które obejmuje działania związane z wyprodukowaniem, dystrybucją oraz użytkowaniem produktu do czasu wycofania z eksploatacji. Przyjmuje się, że najważniejszym wskaźnikiem jakości eksploatacji jest ekonomia eksploatacji, która wynika z poziomu wykorzystywania potencjału eksploatacyjnego zawartego $\mathrm{w}$ obiekcie. Ważne są tu więc działania organizacyjne, techniczne, ekonomiczne i społeczne. Mogą one być podejmowane intuicyjnie i wtedy zależą od przypadkowej wiedzy eksploatatora, oraz profesjonalne, zgodne z nauką o eksploatacji.

Zjawiska eksploatacyjne są elementem każdego działania, a każde działanie jest elementem eksploatacji środowiska. Sprawna eksploatacja urządzeń wymaga od użytkowników przestrzegania pewnych zasad. Kompetencje eksploatacyjne są szczególnie ważne w procesie tworzenia założeń / koncepcji wstępnej i konstruowania obiektów, gdy tworzy się ich własności eksploatacyjne na całe życie, które tylko częściowo można poprawić w procesach innowacyjnych.

Podsumowując, w procesie eksploatacji wyodrębnia się cztery podstawowe rodzaje działań:

- użytkowanie,

- obsługiwanie,

- zasilanie,

1 St. Legutko, Podstawy eksploatacji maszyn i urzqdzeń, WSiP, Warszawa 2004. 
- zarządzanie (można je również określić jako eksploatację systemów zarządzania).

System kierowania eksploatacją w straży pożarnej oparty jest na Zarządzeniu Nr 8 Komendanta Głównego Państwowej Straży Pożarnej z dnia 10 kwietnia 2008 r. w sprawie gospodarki transportowej w jednostkach organizacyjnych Państwowej Straży Pożarnej oraz na Zarządzeniu nr 13 Komendanta Głównego Państwowej Straży Pożarnej z dnia 27 grudnia 2012 r. w sprawie gospodarki transportowej w jednostkach organizacyjnych Państwowej Straży Pożarnej. Jednocześnie obowiązuje Rozporządzenie MSWiA z dnia 08 marca 2004 r. w sprawie badań oraz przeglądów technicznych sprzętu oraz wyposażenia ratowniczo-gaśniczego oraz obiektów PSP (Dz. U. 51 poz. 510). Zgodnie z katalogiem zadań zawodowych osobą posiadającą wymagane kwalifikacje do zarządzania procesem eksploatacji jest inżynier pożarnictwa (kod zawodu 214910)2 i dla niego między innymi dedykowane jest to opracowanie.

Zapoznanie $z$ aparatem badawczym, metodami pozyskiwania danych oraz sposobem wykorzystania rezultatów przybliży tematykę realizowanych projektów badawczych. Potwierdzona zostanie zasada realizacji projektów badawczych ściśle związanych z oczekiwaniami gestora reprezentującego środowisko zawodowe. Dodatkowo, celem szerszego podejścia do zagadnień eksploatacji, zaprezentowano wybrane problemy związane z wdrażaniem do użytkowania innych grup wyposażenia i sprzętu wykorzystywanego w straży pożarnej oraz zarządzania procesem eksploatacji.

Część I poświęcona została problemowi metodologii nadzoru eksploatacji wybranych obszarów wyposażenia straży pożarnej w zakresie niezawodności i skuteczności działania. W skład konsorcjum realizującego projekt wchodzą Centrum Naukowo-Badawcze Ochrony Przeciwpożarowej Państwowy Instytut Badawczy (CNBOP-PIB), Szkoła Główna Służby Pożarniczej (SGSP), CMGI Sp. z o. o., MLABS Sp. z o.o., TELDAT Spółka Jawna Kruszyński Cichocki. Przedstawiony materiał jest wynikiem prac konsorcjum, którego głównym celem jest stworzenie systemu teleinformatycznego zbierającego i przetwarzającego dane oraz wspierającego zadania logistyczne w zakresie serwisowania oraz zakupów sprzętu ratowniczego, a także zawierającego bazę świadectw dopuszczenia wydawanych przez CNBOP-PIB. Na tym etapie realizacji projektu można założyć, iż technologiami determinującymi powodzenie prac będą technologie teleinformatyczne, a w szczególności ich optymalny dobór w stosunku do wypracowanych w ramach projektu wymagań szczegółowych użytkownika. W projekcie kluczowymi elementami determinującymi powodzenie przedsięwzięcia są:

- identyfikacja bieżącego stanu rzeczy w zakresie stosowanego sprzętu w ochronie przeciwpożarowej oraz dobór parametrów do monitorowania - wybrane parametry powinny pozwolić na ocenę niezawodności monitorowanego sprzętu, jak również pozostałego czasu jego bezawaryjnej pracy,

- ustalenie odpowiednich parametrów i procedury badawczej służącej do zbierania odpowiednich danych za pomocą sensorów/czujników,

2 http://www.diagnozowaniekompetencji.pl/?mod=ankieta\&id=151\&flag=on 
- identyfikacja dostępnych technologii w zakresie opracowania demonstratora oprogramowania wspomagającego monitoring eksploatacji wybranych środków wyposażenia straży pożarnej w zakresie niezawodności i skuteczności działania - kluczowym aspektem jest opracowanie modeli wnioskowania bazujących na wynikach badań laboratoryjnych, na podstawie których będzie możliwe szacowanie bezawaryjnej pracy urządzeń.

$\mathrm{Na}$ podstawie wyspecyfikowanych parametrów oraz dzięki wynikom analizy powyższego zadania będzie można określić, które dostępne technologie pozwolą na monitorowanie parametrów newralgicznych. Biorąc pod uwagę fakt, że dane te będą wynikały z etapu prac badawczych i będą wymagały ścisłej współpracy pomiędzy partnerami, w harmonogramie zaplanowano zadanie pt. „Weryfikacja założeń dla systemu monitorowania i analizy”, w którym SGSP dokona weryfikacji przyjętych założeń dotyczących parametrów, przy jednoczesnym porozumieniu z CMGI i Mlabs w kwestii możliwych do zastosowania technologii monitorujących .

W ramach realizacji etapu I konsorcjanci z SGSP oraz CNBOP-PIB opisali najczęściej występujące typy niebezpiecznych zdarzeń zagrażających życiu i zdrowiu ludzi oraz zwierząt, a także mieniu i środowisku, podczas których działania ratowniczo-gaśnicze prowadzą zastępy ratownicze i gaśnicze. Wykonano analizę najczęściej występujących działań ratowniczo-gaśniczych. Określone zostały newralgiczne pod kątem oceny zagrożeń najczęściej występujące uszkodzenia pojazdów i sprzętu pożarniczego powodujące konieczność przerwania akcji ratowniczej. Została wykonana analiza niezawodności wybranych pojazdów i sprzętu pożarniczego. Na podstawie wykonanych analiz wytypowane zostały kluczowe dla powodzenia akcji ratowniczej pojazdy i sprzęt pożarniczy, dla którego wykonany zostanie system monitorowania i oceny stanu technicznego. Efektem tego zadania ma być materiał wejściowy do stworzenia scenariuszy akcji ratowniczych. Zostały wyspecyfikowane rodzaje prowadzonych działań ratowniczo-gaśniczych (przy uwzględnieniu zagadnienia eksploatacji wybranych pojazdów pożarniczych i elementów sprzętu pożarniczego) charakterystyka tych działań, użycie oraz zużycie sprzętu pożarniczego. W scenariuszach akcji ratowniczych szczególna uwaga zostanie skupiona na działaniach ratowniczo-gaśniczych prowadzonych przez zastępy ratownicze PSP oraz na niezbędnym do ich prowadzenia sprzęcie i wyposażeniu.

Jako uzupełnienie prezentowanego materiału dotyczącego sprzętu i wyposażenia przedstawiono problematykę eksploatacji rękawów przeciwpowodziowych. W skład konsorcjum realizującego projekt „Optymalizacja procedur, dyslokacji baz i doskonalenie rozwiązań technicznych sprzętu stosowanego przez polskie służby ratownicze w zakresie przeciwdziałania zagrożeniom naturalnym ze szczególnym uwzględnieniem powodzi (rękawy przeciwpowodziowe)" wchodzą: Instytut Technologii Bezpieczeństwa „MORATEX”, CNBOP-PIB, Delta Rescue, Zakład Pracy Chronionej - Przedsiębiorstwo PHU. „LESTER”, Wyższa Szkoła Zarządzania i Prawa im. Heleny Chodkowskiej, AMZ-KUTNO Sp. z o.o., Szkoła Główna Służby 
Pożarniczej. Autorzy przedstawiają zagadnienie eksploatacji jako zbiór obejmujący użytkowanie, dekontaminację oraz recykling. Wszystkie te etapy nastręczają wiele problemów, a każdy z nich jest jednakowo ważny.

Rozdział II poświęcony został kwestii monitoringu eksploatacji nowych produktów będących wynikiem realizacji projektu pn. „Nowoczesne rozwiązania ochron osobistych dla służb ratowniczych KSRG w oparciu o potrzeby użytkowników końcowych". Przedstawiony materiał stanowi zbiór prac wykonanych przez konsorcjantów związanych z tworzeniem produktów projektu oraz prowadzonymi pracami badawczymi. Projekt FIREGUARD 2015 realizują: Szkoła Główna Służby Pożarniczej, Centrum Naukowo-Badawcze Ochrony Przeciwpożarowej - Państwowy Instytut Badawczy (CNBOP-PIB), Instytut Technologii Bezpieczeństwa „MORATEX”, Politechnika Łódzka, Uniwersytet Medyczny w Łodzi, Centralny Instytut Ochrony Pracy - PIB, Związek Ochotniczych Straży Pożarnych Rzeczypospolitej Polskiej, Wytwórnia Umundurowania Strażackiego, ARLEN S.A., TEXA s.c. Jakub i Kazimierz Targalski, Kaliskie Zakłady Przemysłu Terenowego w Kaliszu Sp. z o.o.

Założeniem projektu rozwojowego FIREGUARD 2015 jest zastosowanie najnowszych osiągnięć technologii tekstylnych umożliwiających spełnienie rosnących wymagań stawianych kompleksowym ochronom osobistym. W założeniach projektu główny akcent postawiono na wymagania odnośnie odporności i optymalizowanej skuteczności ochrony przed zagrożeniami ze strony czynników środowiska podczas działań ratowniczo-gaśniczych przy zachowaniu pełnego komfortu pracy ratownika. W ramach projektu wypracowano strukturę produktów obejmującą istotne we współczesnych uwarunkowaniach elementy takie jak:

- procedury wykorzystania kompleksowego systemu ochron osobistych;

- prototyp innowacyjnego hełmu strażackiego;

- prototypy ubrań specjalnych:

- ubrania strażackiego o maksymalnie ograniczonej masie;

- ubrania strażackiego do działań ratowniczo-gaśniczych na przestrzeniach otwartych;

- systemy monitorowania funkcji życiowych ratownika podczas czynności ratowniczych;

- ćwiczebny system zintegrowany;

- ćwiczebny system niezależny;

- badania ergonomiczne i eksploatacyjne środków ochrony indywidualnej w warunkach poligonowych i rzeczywistych.

$\mathrm{W}$ projekcie stworzono narzędzie umożliwiające weryfikację w warunkach rzeczywistych ergonomiczności odzieży strażackiej oraz badań psychomotorycznych ratowników oparte na elektronicznym systemie złożonym $\mathrm{z}$ jednostki centralnej, przekaźników radiowych oraz tzw. ubrania inteligentnego (typu „smart”) wyposażonego $\mathrm{w}$ urządzenia elektroniczne umożliwiające zdalne pomiary parametrów środowiskowych oraz fizjologicznych. 
Ćwiczebny system zintegrowany opracowany został do realizacji funkcji automatycznej: oceny poziomu zmęczenia strażaka (wykrywanie stanu zagrożenia dla zdrowia i życia), analizy wydolności organizmu (test wysiłkowy), lokalizacji strażaka na poligonie i w komorze testowej, analizy parametrów odzieży, oceny komfortu odzieży ochronnej.

System ćwiczebny niezależny posiada analogiczne funkcje monitorowania parametrów ratowników do systemu zintegrowanego. Różnica polega na umieszczeniu układów pomiarowych w specjalnie zaprojektowanym podkoszulku zamiast w kurtce. Dzięki temu system umożliwia prowadzenie pomiarów parametrów fizjologicznych ratowników wykorzystujących podczas ćwiczeń różne ubrania wierzchnie. Rozwiązanie to pozwala na porównywanie komfortu zapewnianego przez ubrania strażackie różnych konstrukcji. System niezależny może być stosowany wraz z dowolnym ubraniem wierzchnim, do którego od zewnątrz dołączony zostanie moduł osobisty.

W publikacji znalazły się opracowania dotyczące procesu badawczego ubrań specjalnych - omówiona w nich została nowatorska technika badawcza do oceny własności użytkowych. Przedstawiono również wyniki badań po przeprowadzonej modernizacji rozwiązań konstrukcyjnych.

Jako uzupełnienie prezentowanego materiału przedstawiono jeden z elementów realizowanego projektu pn. „Opracowanie innowacyjnego systemu stanowisk do badań ochron osobistych" dotyczącego doskonalenia metod oceny ochron osobistych, w którym uczestniczą: SGSP, CNBOP-PIB, Politechnika Warszawska (MEiL), Szkoła Aspirantów PSP w Krakowie, Thermolab spółka cywilna w Warszawie. W opracowaniu dokonano przeglądu polskich i wybranych zagranicznych norm dotyczących metod badania odzieży ochronnej strażaków poddanej oddziaływaniu ciepła. Scharakteryzowano metody pomiarowe i wskaźniki użyte do oceny odzieży pod względem ochrony przed poparzeniem. Omówiono model matematyczny zastosowany do modelowania numerycznego transportu ciepła i wilgoci w ochronach osobistych strażaków. Podano przykładowe dane dotyczące odzieży i skóry człowieka, niezbędne do przeprowadzenia obliczeń. Przedstawiono wnioski odnoszące się do sposobu oceny ochron osobistych strażaków. Zaproponowano modyfikację metod pomiarowych, wskazano na konieczność badań zawilgoconych próbek odzieży ochronnej oraz jej pojemności cieplnej. Zaprezentowano możliwość wykorzystania symulacji numerycznych do oceny skuteczności ochron osobistych przy znajomości właściwości radiacyjnych poszczególnych warstw odzieży.

Jesteśmy przekonani, że przedstawione rezultaty prac realizowanych w ramach różnych projektów badawczych przez konsorcja, w skład których wchodzi CNBOP-PIB, finansowanych przez Narodowe Centrum Badań i Rozwoju, pozwolą na przybliżenie problemów związanych z eksploatacją oraz nadzorowaniem zachodzących w czasie użytkowania procesów, które są uwzględniane już na etapie projektowania oraz badań zarówno prototypów, jak i egzemplarzy produkcyjnych. 



\title{
CzĘść I
}

\author{
NADZÓR NAD EKSPLOATACJĄ \\ WYBRANYCH OBSZARÓW WYPOSAŻENIA \\ STRAŻY POŻARNEJ W ZAKRESIE NIEZAWODNOŚCI \\ I SKUTECZNOŚCI DZIAŁANIA
}





\title{
METODYKA I KRYTERIA WYBORU OBIEKTÓW DO BADAŃ
}

\author{
Dariusz Czerwienko \\ Leszek Jurecki \\ Jacek Roguski
}

\section{Założenia projektowe}

Program realizacji projektu nr DOBR-BIO4/051/13087/2013 pt. „Opracowanie metodologii stałego nadzoru eksploatacji wybranych obszarów wyposażenia straży pożarnej w zakresie niezawodności i skuteczności działania” zakłada osiągnięcie efektu końcowego, którym będzie system informatyczny (ryc. 1) pozwalający określić istotne z punktu widzenia eksploatacji parametry wyposażenia, opracować metody doskonalenia tych parametrów w celu poprawy bezpieczeństwa ratownika i skuteczności prowadzonych działań oraz monitorować bieżące zużycie sprzętu. Zapewnią to funkcje operacyjne systemu tworzonego w ramach projektu takie jak:

- stały monitoring eksploatacji wybranego sprzętu wyposażenia straży pożarnej w zakresie niezawodności i skuteczności działania;

- efektywne zarządzanie i prezentacja zgromadzonych informacji;

- wspomaganie działań logistycznych dzięki danym otrzymanym z systemu diagnostyki. Zbierane dane statystyczne, takie jak np. średni czas działania pomiędzy awariami, posłużą do prognozowania zużycia sprzętu w jednostkach ratowniczo-gaśniczych, które nie zostaną objęte systemem monitoringu;

- możliwość ręcznego wprowadzania do systemu ewidencji nowych jednostek straży pożarnej wraz z listą posiadanego sprzętu oraz stanu jego zużycia oraz aktualizacji bazy sprzętu po akcjach ratowniczych lub serwisach technicznych;

- możliwość objęcia wsparciem logistycznym sprzętu, który nie podlega bezpośredniemu monitoringowi przez system diagnostyki technicznej. System na podstawie danych $\mathrm{z}$ bieżącej ewidencji będzie mógł dokonywać prognoz eksploatacyjnych, wyznaczać listy elementów wyposażenia, które ulegną uszkodzeniu $\mathrm{w}$ najbliższym czasie oraz dostarczyć dane do podejmowania działań logistycznych. 


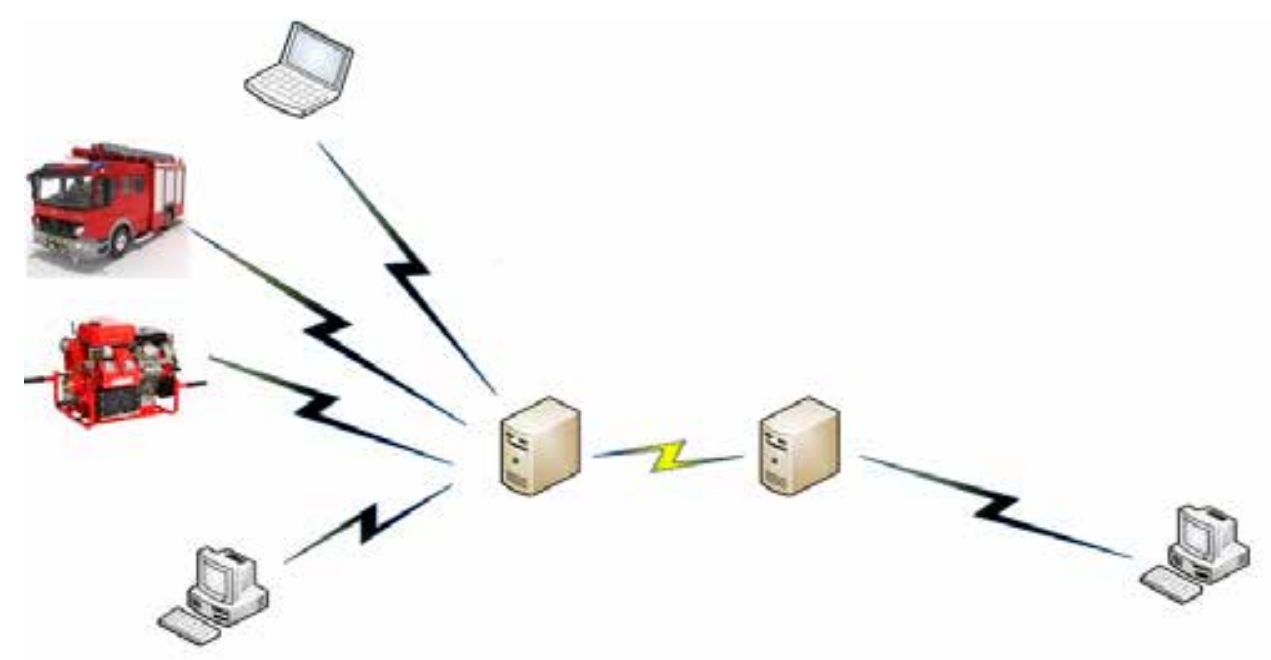

Ryc. 1. Schemat systemu monitoringu

Źródło: Opracowanie własne na podstawie J. Roguski, D. Wróblewski i inni, Opracowanie metodologii stałego nadzoru eksploatacji wybranych obszarów wyposażenia straży pożarnej w zakresie niezawodności i skuteczności działania, [w:] Aktualne problemy bezpieczeństwa pożarowego, VNIIPO, Moskwa 2014, 501-504.

$\mathrm{W}$ ramach prowadzonych zadań badawczych przeanalizowano istniejące rozwiązania konstrukcyjne oraz zidentyfikowano sprzęt stosowany przez PSP podczas akcji ratowniczo-gaśniczych. Istotą prowadzonych działań było rozpoznanie rozwiązań technicznych stosowanych w zakresie sprzętu wykorzystywanego w ochronie przeciwpożarowej na podstawie informacji zgromadzonych w bazach danych Komendy Głównej PSP, komend wojewódzkich PSP, komend miejskich PSP oraz wybranych jednostek OSP ze szczególnym uwzględnieniem pojazdów, motopomp, autopomp i narzędzi hydraulicznych, czyli sprzętu najczęściej stosowanego podczas akcji ratowniczo-gaśniczych. Opracowana identyfikacja działań oraz przeprowadzone ustalenia umożliwiły dokonanie wyboru niezbędnego wyposażenia pomiarowego oraz przygotowanie dokumentacji stanowisk pomiarowych. Na podstawie opracowanej identyfikacji działań przeprowadzono ustalenia dotyczące ${ }^{1}$ :

1. najbardziej zawodnego sprzętu,

2. występujących rodzajów uszkodzeń,

3. średniego czasu pomiędzy uszkodzeniami,

4. intensywności użytkowania wybranego sprzętu,

5. współczynnika gotowości wytypowanego sprzętu.

Powyższe dane oraz analiza parametrów pracy jest podstawą do wytypowania istotnych parametrów diagnostycznych wybranego sprzętu pożarniczego. Ze względu na sposób realizacji prac projektowych zaproponowano budowę Lokalnego

1 Wniosek DOBR-BIO4/051/13087/2013. 
Środowiska Badawczego. Aparatura naukowo-badawcza zostanie wykorzystana do stworzenia odpowiednich warunków laboratoryjnych, które umożliwią pozyskanie danych do dalszych analiz.

Powstałe środowisko badawcze umożliwi badania przyśpieszonego starzenia, a dzięki odpowiedniemu oprogramowaniu pozwoli zbierać, a także przetwarzać dane, które będą przekazywane do systemu. Przeprowadzenie badań według opracowanych procedur i programów na stanowiskach wykonanych zgodnie z wytworzoną dokumentacją pozwoli na:

- określenie wzorcowych parametrów diagnostycznych sprawnego sprzętu pożarniczego,

- określenie wartości parametrów diagnostycznych w funkcji zużycia/starzenia sprzętu pożarniczego,

- określenie wartości parametrów diagnostycznych odpowiadających wytypowanym najczęstszym uszkodzeniom sprzętu pożarniczego,

- opracowanie algorytmów diagnozowania, prognozowania i generowania (oceny) stanu technicznego wybranego sprzętu pożarniczego. Efektem badań będą rekomendacje do nowelizacji wymagań techniczno-użytkowych wyposażenia straży pożarnej oraz wytycznych dla producentów w zakresie poprawy funkcjonalności i niezawodności wybranych grup sprzętowych.

W ramach prowadzonych analiz teoretycznych do badań wytypowane zostały następujące grupy sprzętu i wyposażenia:

- autopompa A 16/8 ze stopniem wysokiego ciśnienia (WC),

- autopompa A 24/8 ze stopniem WC,

- motopompa pożarnicza,

- motopompa pływająca,

- motopompa do wody zanieczyszczonej,

- zestaw hydraulicznych narzędzi ratowniczych składający się z nożyc, rozpieracza ramieniowego, cylindra rozpierającego oraz agregatu zasilającego.

Projekt ma przede wszystkim na celu:

- ustalenie granic trwałości, racjonalnych ze względów technicznych i ekonomicznych,

- określenie zależności między trwałością a okresem użytkowania,

- określenie stopnia wykorzystania,

- badanie warunków eksploatacji,

- opracowanie metod badań eksploatacji urządzeń,

- opracowywanie sposobów rozpoznawania przyczyn uszkodzeń,

- opracowywanie metod badań w zakresie trwałości maszyn, opracowywanie obiektywnych wskaźników trwałości produkowanych urządzeń. 
W przypadku sprzętu pożarniczego, jak również innych wyrobów ogólnie stosowanych w życiu codziennym daje się zauważyć pewną prawidłowość, którą obrazuje tzw. Krzywa zużycia Lorenza (ryc. 2). Ww. sprzęt najbardziej zużywa się, uszkadza i tym samym najwięcej awarii jest na początku jego użytkowania (okres I) oraz na końcu (okres III). Pomiędzy jest długi okres stabilnej pracy, który następuje po „dotarciu się" nowego wyrobu.

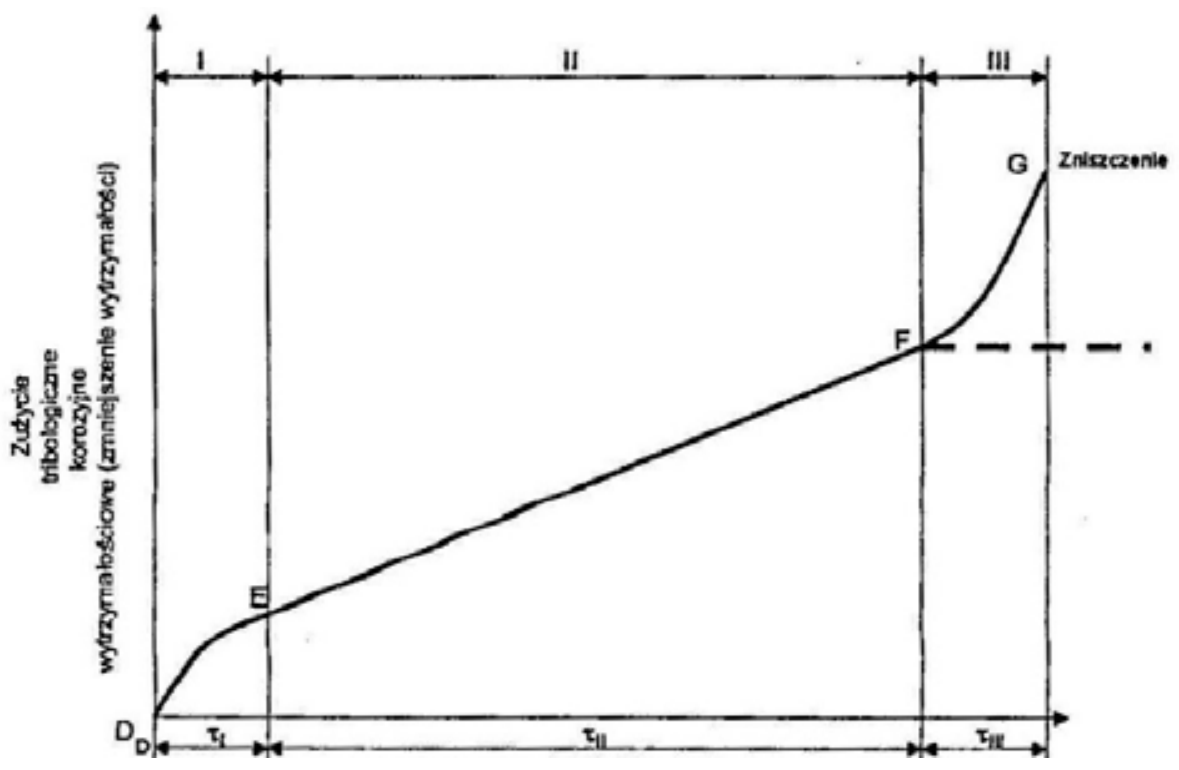

Ryc. 2. Krzywa Lorenza I - okres zużycia nieustalonego, II - okres zużycia ustalonego, III - okres zużycia przyśpieszonego

Źródło: Opracowanie na podstawie S. Niziński, J. Żurek, Logistyka ogólna, Warszawa 2011.

Potwierdzeniem powyższej reguły są między innymi dane zawarte w tabeli 1 . Do badań w CNBOP-PIB przyjmowane są wyroby nowe. Często na etapie badań występuje wiele niezgodności w stosunku do wymagań, a nawet dochodzi do uszkodzenia nw. wyrobów. W przypadku pojazdów ratowniczo-gaśniczych najczęściej dochodzi do:

- uszkodzenia (rozszczelnienia lub zatarcia) przystawki dodatkowego odbioru mocy,

- uszkodzenia urządzenia zasysającego,

- nieszczelności autopompy i elementów układu wodno-pianowego po stronie ssawnej i tłocznej,

- dozownik środka pianotwórczego nie uzyskuje odpowiednich stężeń w całym zakresie wydajności autopompy,

- nieprawidłowej pracy elementów pulpitu sterowniczego,

- pęknięcia wałów napędowych. 
Procentowy udział niezgodności w badaniach prowadzonych przez Zespót Laboratoriów Technicznego Wyposażenia Straży Pożarnej i Technicznych Zabezpieczeń Przeciwpożarowych (BS)

\begin{tabular}{|c|c|c|}
\hline Lp. & Grupa wyrobów & $\begin{array}{c}\text { \% procesów badań ze stwierdzonymi } \\
\text { nieprawidłowościami }\end{array}$ \\
\hline 1. & $\begin{array}{c}\text { Pompy pożarnicze (autopompy, } \\
\text { motopompy pożarnicze, motopompy } \\
\text { pływające, do wody zanieczyszczonej) }\end{array}$ & $90 \%$ \\
\hline 2. & Pojazdy pożarnicze & $98 \%$ \\
\hline 3. & Narzędzia ratownicze & $47 \%$ \\
\hline
\end{tabular}

Źródło: Opracowanie własne BS.

\section{Analiza wykorzystania samochodów pożarniczych w straży pożarnej (SP)}

Aby ograniczyć nakłady na prowadzone badania sprzętu, wprowadzono pewne uproszczenia, opierając się na wynikach wcześniejszych badań użytkowych realizowanych w CNBOP-PIB. Na tej podstawie przyjęto model samochodu ratowniczogaśniczego, w którym wydzielono bloki funkcjonalne decydujące o prawidłowości zadziałania dla wykonania określonych zadań funkcjonalnych ${ }^{2}$.

Z punktu widzenia niezawodności sprzętu wykorzystywanego w ochronie przeciwpożarowej, a w szczególności pojazdów pożarniczych, najistotniejszymi elementami są:

- autopompa,

- dozownik,

- linia szybkiego natarcia,

- działko wodno-pianowe,

- elementy sterujące i kontrolujące

- przystawka dodatkowego odbioru mocy,

- wały napędowe.

2 Materiały projektu DOBR-BIO4/051/13087/2013 „Opracowanie metodologii stałego nadzoru eksploatacji wybranych obszarów wyposażenia straży pożarnej w zakresie niezawodności i skuteczności działania” finansowanego przez Narodowe Centrum Badań i Rozwoju. 

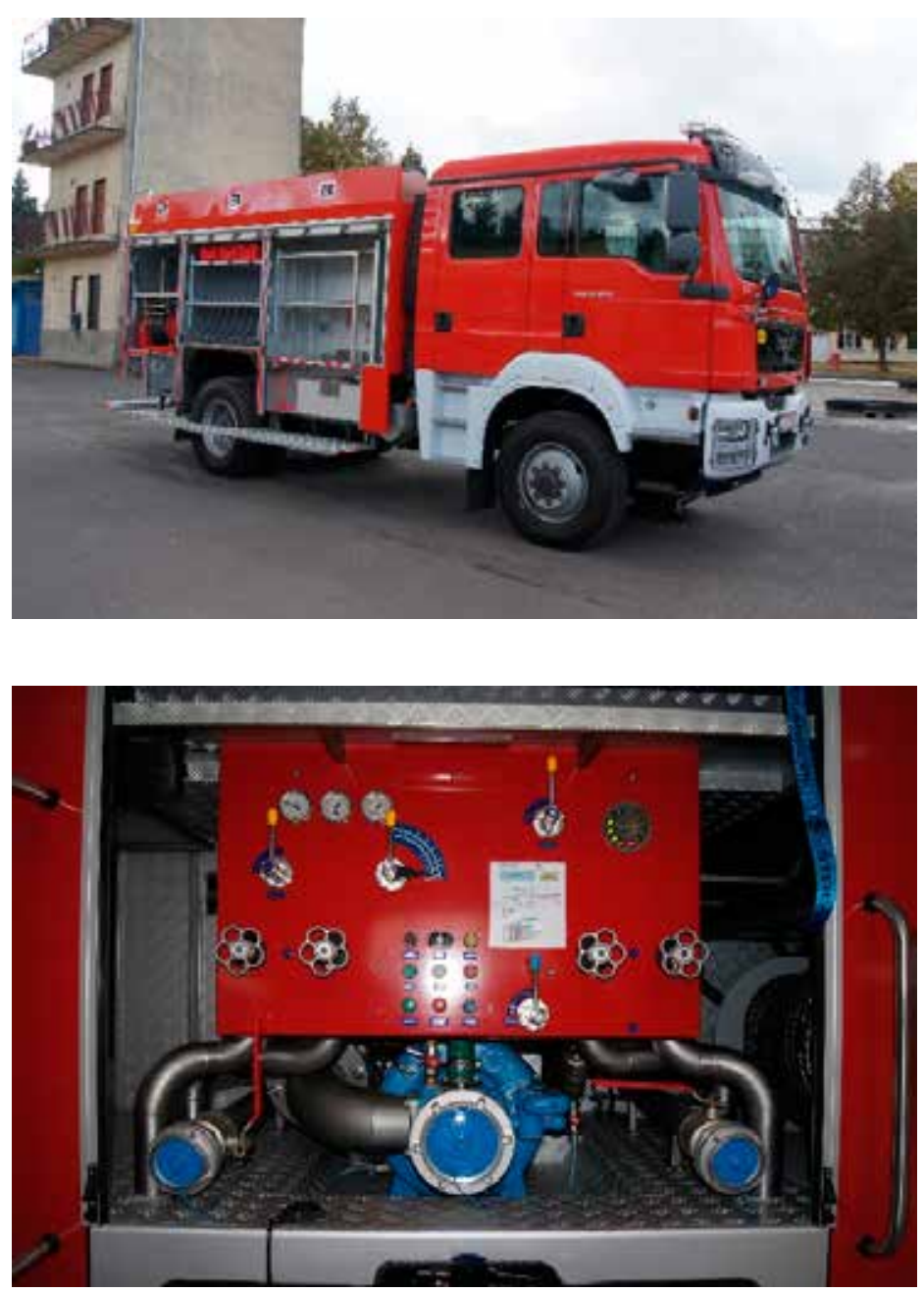

Ryc. 3. Samochód ratowniczo-gaśniczy

Źródło: Archiwum CNBOP-PIB.

Dla przyjętego modelu przeprowadzono analizę najczęściej wykorzystywanego sprzętu w jednostkach straży pożarnej. Badaniami objęte zostały wszystkie grupy samochodów pożarniczych wodno-pianowych wykorzystywanych w jednostkach należących do krajowego systemu ratowniczo-gaśniczego (KSRG), jak również użytkowanych w działaniach ratowniczo-gaśniczych poza systemem. Na podstawie uzyskanych danych stwierdzono, że najczęściej wykorzystywanym sprzętem są samochody ratowniczo-gaśnicze typu średniego i typu ciężkiego (tabela 2) ${ }^{3}$.

3 J. Roguski, D. Wróblewski, A. Majka, Разработка современных учебных стендов для повышения эффективности работ выполняемых работниками Национальной Системы Спасания и Тушения (KSRG), referat na XXIV międzynarodowej konferencji Moskwa, 03-04.07.2012 r. (niepublikowany). 


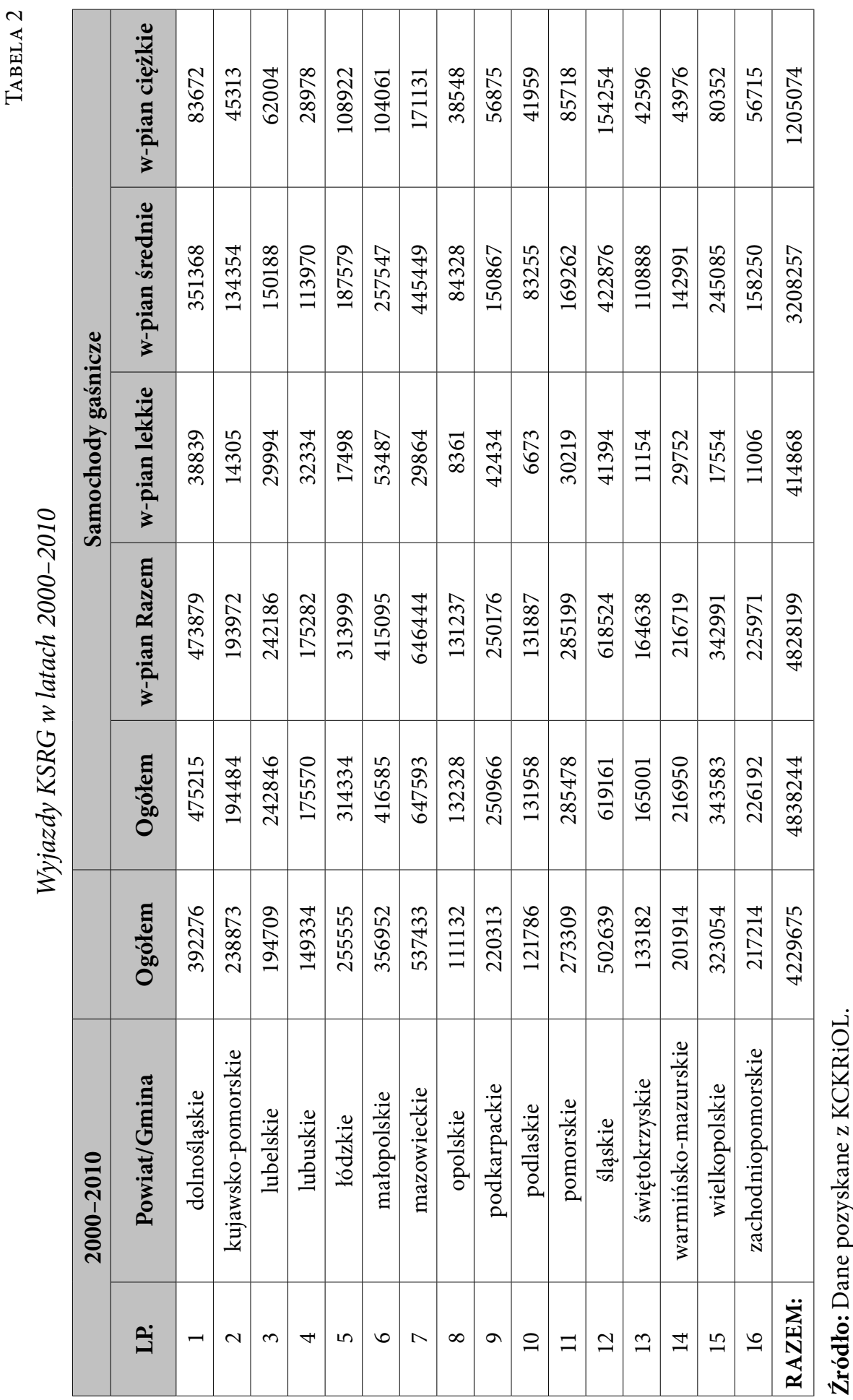




\section{Analiza częstotliwości wyjazdów samochodów ratowniczo-gaśniczych oraz innych samochodów pożarniczych}

Przykładowo w 2010 roku pojazdy takie wyjeżdżały do akcji ponad 378 tys. razy. Następną grupą pojazdów są ciężkie samochody ratowniczo-gaśnicze (wodno-pianowe), które wyjeżdżały do akcji ponad 110 tys. razy.

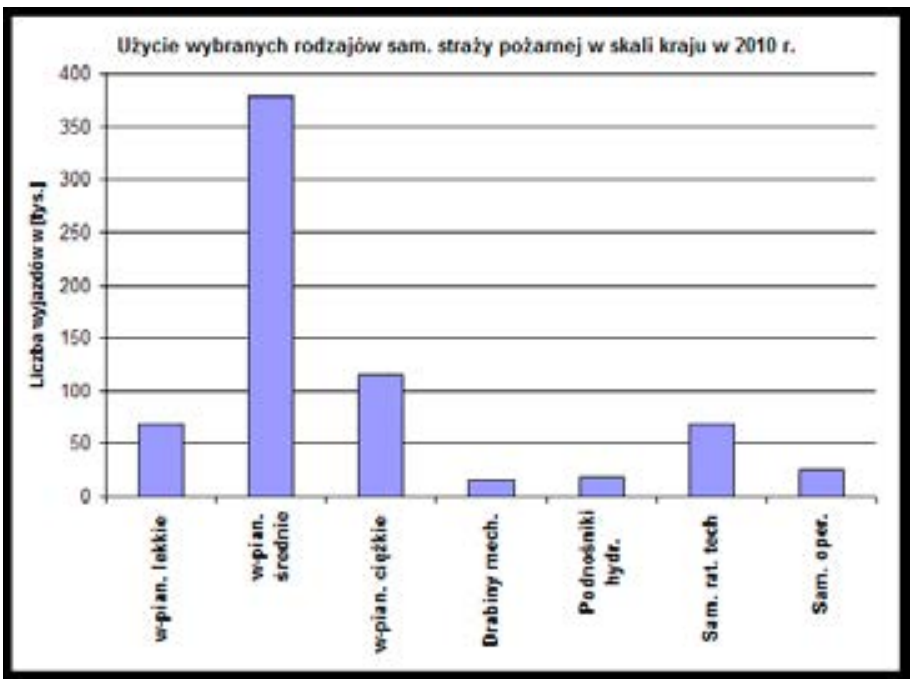

Ryc. 4. Użycie wybranych rodzajów samochodów straży pożarnej w skali kraju w 2010 r. Źródło: Opracowanie własne na podstawie danych KCKRiOL.

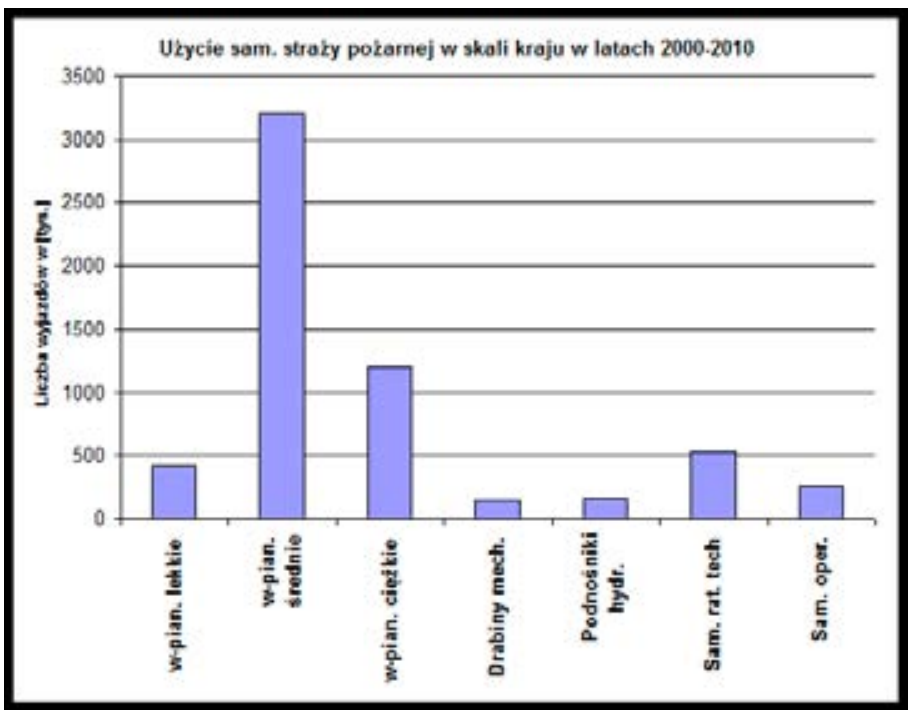

Ryc. 5. Użycie samochodów straży pożarnej w skali kraju w latach 2000-2010 Źródło: Opracowanie własne na podstawie danych KCKRiOL. 
Wyniki analizy danych statystycznych za lata 2000-2010 potwierdzają prawidłowość, że najczęściej wykorzystywane w działaniach ratowniczo-gaśniczych są średnie i ciężkie samochody ratowniczo-gaśnicze.

\section{Analiza wykorzystania motopomp w działaniach ratowniczo-gaśniczych}

W celu określenia intensywności użytkowania motopomp w działaniach ratowniczo-gaśniczych posłużono się danymi zawartymi lub otrzymanymi z:

- EKSPON,

- KCKRiOL,

- SWD-ST KSIS.

Motopompy pożarnicze w chwili obecnej rzadko używane są w Państwowej Straży Pożarnej do bezpośrednich akcji związanych z gaszeniem pożarów. Służą głównie do przetłaczania wody na większe odległości. Przewożone są głównie na lekkich samochodach ratowniczo-gaśniczych lub na przyczepach.

Motopompy pożarnicze są wykorzystywane podczas akcji ratowniczo-gaśniczych głównie przez Ochotnicze Straże Pożarne.

Według danych na koniec 2013 roku Państwowa Straż Pożarna dysponowała:

- 1015 lekkimi samochodami ratowniczo-gaśniczymi,

- 865 motopompami klasy M 8/8,

- 243 motopompami klasy M 16/8 i większymi.

Rozporządzenie Ministra Spraw Wewnętrznych i Administracji z dnia 27 kwietnia 2010 r. zmieniające rozporządzenie w sprawie wykazu wyrobów służących zapewnieniu bezpieczeństwa publicznego lub ochronie zdrowia i życia oraz mienia, a także zasad wydawania dopuszczenia tych wyrobów do użytkowania (Dz. U. z $2010 \mathrm{Nr} 85$, poz. 553) 4 oraz inne przepisy, w tym standardy KG PSP, nie określają precyzyjnie, w jakich typach pojazdów należy stosować motopompę pożarniczą.

Niestety dane statystyczne uzyskane z KG PSP nie przedstawiają informacji na temat użycia motopomp pożarniczych ze względu na klasę pojazdu, w którym jest przewożona. Ponadto brakuje informacji o producencie motopompy, która byłaby istotną wskazówką odnośnie konstrukcji motopompy.

Jeśli chodzi o zużycie i awaryjność tego rodzaju sprzętu najczęściej występującymi objawami nieprawidłowej pracy są nieszczelności i utrata parametrów nominalnych. W chwili obecnej coraz częściej wykorzystuje się elektroniczne systemy pracy i kontroli, co przy nieprawidłowym użytkowaniu powoduje uszkodzenia.

Duża liczba użytkowanych motopomp to stare konstrukcje, w przypadku których częstą przyczyną uszkodzeń jest starzenie się materiałów. Ważnym czynnikiem

4 Materiały projektu DOBR-BIO4/051/13087/2013 „Opracowanie metodologii stałego nadzoru eksploatacji wybranych obszarów wyposażenia straży pożarnej w zakresie niezawodności i skuteczności działania” finansowanego przez Narodowe Centrum Badań i Rozwoju. 
mającym wpływ na niezawodność motopomp jest częstotliwość ich użytkowania. Najczęściej występujące przyczyny uszkodzeń motopomp przedstawiono na ryc. 6 .

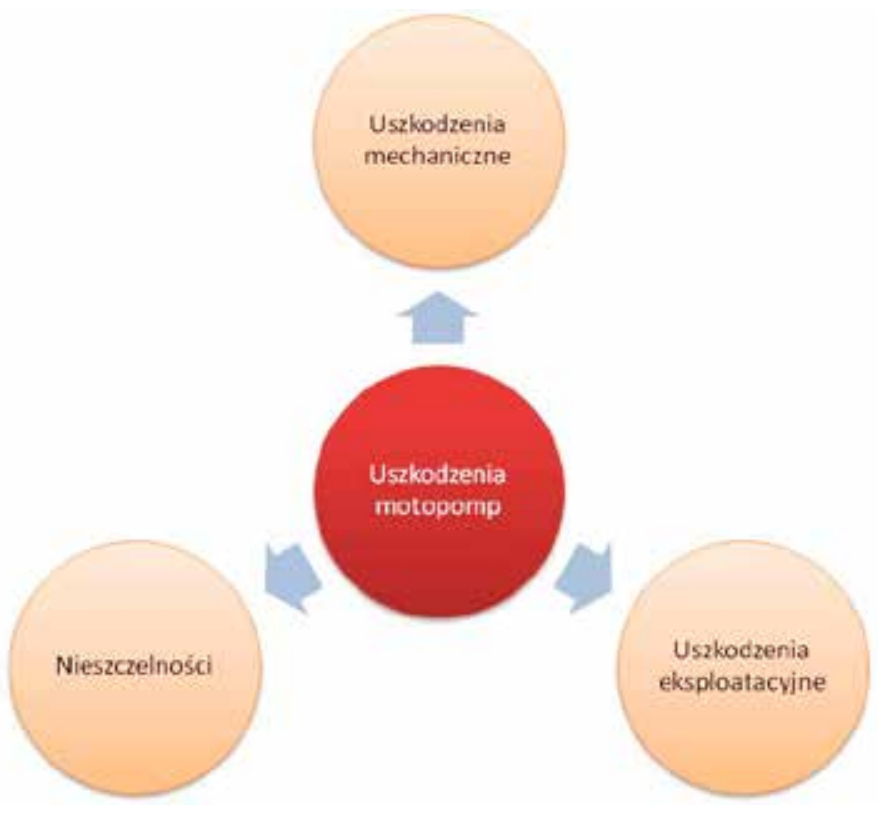

Ryc. 6. Podział uszkodzeń motopomp

Źródło: Opracowanie własne na podstawie http://motofocus.pl/technika/10389/pompy-wody -w-napedach-rozrzadu-problemy-czesc- 1 .

Na ryc. 6 przedstawiono typowe uszkodzenia motopomp wynikające $\mathrm{z}$ awarii mechanicznych, które mogą być spowodowane nieprawidłowym sposobem przechowywania lub wypadkami losowymi. Do tej grupy uszkodzeń zaliczamy również uszkodzenia spowodowane przez wady fabryczne motopompy, tj. niewłaściwe złożenie motopompy w czasie produkcji. Następnym rodzajem uszkodzeń są uszkodzenia eksploatacyjne spowodowane użytkowaniem motopompy, w wyniku normalnego zużycia zgodnie z założeniem producenta, a także w przypadkach, gdy nie są przestrzegane zalecenia producenta np. dotyczące wymiany płynów eksploatacyjnych, świec, czy też zaprzestanie czynności serwisowych takich jak regulacja luzów zaworów. Natomiast do ostatniej grupy uszkodzeń dla motopomp zaliczamy wszelkie nieszczelności spowodowane zastosowaniem niewłaściwych płynów reagujących z materiałami, z których została wykonana motopompa.

\section{Rodzaje uszkodzeń motopomp oraz średni czas pomiędzy uszkodzeniami}

Motopompa, podobnie jak wszystkie inne urządzenia, wcześniej czy później ulega uszkodzeniu. Jedną z przyczyn może być jej niewłaściwa obsługa. W tym 
przypadku często dochodzi do ograniczenia bądź całkowitego zablokowania przepływu z powodu osadzania się zanieczyszczeń na sicie wlotu ssawnego lub zatkania wylotów tłocznych. Nieszczelne bądź źle działające urządzenie samozasysające nie ma możliwości zassania wody z większych głębokości ssania.

W przypadku, gdy do układu dostaną się zanieczyszczenia, wzrastają drgania i hałas podczas pracy, co w znacznym stopniu przyczynia się do szybszego zużywania się sprzętu. Często w warunkach zimowych zamarznięta woda pozostająca w układzie powoduje pęknięcia nasad i rozszczelnienie układu, w sytuacjach skrajnych może spowodować pęknięcie korpusu. Główną przyczyną w tym przypadku jest złe odwodnienie układu wodnego.

Pozostałe przyczyny uszkodzeń związane ze złą jakością dostarczonej motopompy to przegrzanie się spowodowane złym smarowaniem, uszkodzenie membran urządzenia zasysającego.

Żadne dane statystyczne nie podają ww. informacji, dlatego bardzo ciężko jest określić czasy pomiędzy tymi uszkodzeniami.

Według danych producentów najczęstszą przyczyną uszkodzeń jest niewłaściwa obsługa motopomp.

\section{Intensywność użytkowania autopomp w działaniach ratowniczo-gaśniczych}

Do analizy posłużono się danymi za rok 2013. Na dzień 31.12.2013 r. w dyspozycji Państwowej Straży Pożarnej znajdowało się:

- 754 średnich samochodów ratowniczo-gaśniczych,

- 661 ciężkich samochodów ratowniczo-gaśniczych.

W średnich pojazdach ratowniczo-gaśniczych, zgodnie z załącznikiem do Rozporządzenia Ministra Spraw Wewnętrznych i Administracji z dnia 27 kwietnia 2010 r. zmieniającym rozporządzenie w sprawie wykazu wyrobów służących zapewnieniu bezpieczeństwa publicznego lub ochronie zdrowia i życia oraz mienia, a także zasad wydawania dopuszczenia tych wyrobów do użytkowania (Dz. U. z $2010 \mathrm{Nr}$ 85 , poz. 553) ${ }^{5}$, stosuje się autopompę klasy A16/8. W pojazdach ciężkich stosuje się autopompy klasy A24/8 i większe.

W związku z tym, że dane statystyczne prezentowane przez KG PSP nie przedstawiają podziału użycia sprzętu ze względu na klasę, rodzaj zastosowanego samochodu ratowniczo-gaśniczego w połączeniu z parametrami i możliwościami wyposażenia gaśniczego, w dalszych rozważaniach przyjmiemy powyższe dane.

Zgodnie ze statystykami KG PSP (tabela 3) w 2013 roku mieliśmy do czynienia ze 126426 pożarami oraz 249559 miejscowymi zagrożeniami.

5 J. Roguski, D. Wróblewski, A. Majka, dz. cyt. 
Zestawienie liczby pożarów i zagrożeń miejscowych w 2013 roku

\begin{tabular}{|c|c|r|r|}
\hline Lp. & Podział administracyjny & Pożar & Miejscowe zagrożenie \\
\hline & Polska & 126426 & 249559 \\
\hline 1. & Dolnośląskie & 12994 & 25511 \\
\hline 2. & Kujawsko-Pomorskie & 6124 & 14427 \\
\hline 3. & Lubelskie & 5922 & 11377 \\
\hline 4. & Lubuskie & 4759 & 8325 \\
\hline 5. & Lódzkie & 7207 & 20501 \\
\hline 6. & Małopolskie & 8690 & 25618 \\
\hline 7. & Mazowieckie & 16557 & 31347 \\
\hline 8. & Oppolskie & 3268 & 4833 \\
\hline 9. & Podkarpackie & 6056 & 12226 \\
\hline 10. & Podlaskie & 3065 & 6701 \\
\hline 11. & Pomorskie & 7881 & 16317 \\
\hline 12. & Śląskie & 16716 & 26762 \\
\hline 13. & Świętokrzyskie & 5027 & 5190 \\
\hline 14. & Warmińsko-Mazurskie & 6485 & 10777 \\
\hline 15. & Wielkopolskie & 7517 & 20963 \\
\hline 16. & Zachodniopomorskie & 8158 & 8684 \\
\hline
\end{tabular}

Źródło: Dane statystyczne KG PSP [www.kgpsp.gov.pl].

Czas działań ratowniczych dla poszczególnych rodzajów zdarzeń przedstawia tabela 4 .

Tabela 4

Czas działań ratowniczych dla poszczególnych rodzajów zdarzeń

\begin{tabular}{|l|c|c|c|c|c|c|c|}
\hline \multicolumn{1}{|c|}{ Rodzaj zdarzenia } & \multicolumn{7}{|c|}{ Czas działań ratowniczych } \\
\hline & $\begin{array}{c}\text { do 30 } \\
\text { min }\end{array}$ & $\begin{array}{c}\mathbf{3 1 - 6 0} \\
\text { min }\end{array}$ & $\begin{array}{c}\mathbf{6 1 - 1 2 0} \\
\text { min }\end{array}$ & $\begin{array}{c}\mathbf{1 2 1 - 2 4 0} \\
\text { min }\end{array}$ & $\begin{array}{c}\mathbf{2 4 1 - 7 2 0} \\
\text { min }\end{array}$ & $\begin{array}{c}\text { Do 1 } \\
\text { dnia }\end{array}$ & powyżej \\
\hline Pożar & 55432 & 40820 & 21339 & 6666 & 1913 & 190 & 62 \\
\hline $\begin{array}{l}\text { Czas działań razem } \\
\text { (godz.) }\end{array}$ & 27716 & 40820 & 42678 & 26664 & 22956 & 4560 & \\
\hline Miejscowe zagrożenie & 74974 & 85629 & 53679 & 24953 & 9447 & 605 & 257 \\
\hline $\begin{array}{l}\text { Czas działań razem } \\
\text { (godz.) }\end{array}$ & 37487 & 85629 & 107358 & 99812 & 113364 & 14520 & \\
\hline
\end{tabular}

Przyjęto maksymalne czasy działań ratowniczych.

Źródło: Dane statystyczne KG PSP [www.kgpsp.gov.pl].

W tabeli 5. zawarto dane dot. wykorzystania samochodów ratowniczo-gaśniczych, (w sumie 498198), z czego: 
Wykorzystanie samochodów ratowniczo-gaśniczych

\begin{tabular}{|c|c|c|c|c|}
\hline $\begin{array}{c}\text { Liczba } \\
\text { pojazdów } \\
\text { gaśniczych } \\
\text { lekkich }\end{array}$ & $\begin{array}{c}\text { Liczba } \\
\text { pojazdów } \\
\text { gaśniczych } \\
\text { średnich }\end{array}$ & $\begin{array}{c}\text { Liczba } \\
\text { pojazdów } \\
\text { gaśniczych } \\
\text { ciężkich }\end{array}$ & $\begin{array}{c}\text { Liczba } \\
\text { pojazdów } \\
\text { gaśniczych } \\
\text { proszkowych }\end{array}$ & $\begin{array}{c}\text { Liczba } \\
\text { pojazdów } \\
\text { gaśniczych } \\
\text { innych }\end{array}$ \\
\hline 46319 & 333402 & 113422 & 4932 & 123 \\
\hline
\end{tabular}

Źródło: Dane statystyczne KG PSP [www.kgpsp.gov.pl].

Pojazdy średnie i ciężkie stanowią prawie 90\% wszystkich pojazdów użytych w akcjach ratowniczo-gaśniczych.

Tabela 6. zawiera dane dot. użycia autopomp w trakcie działań ratowniczogaśniczych.

TABELA 6

Użycie autopomp $w$ trakcie działań ratowniczo-gaśniczych

\begin{tabular}{|l|c|c|c|}
\hline \multicolumn{1}{|c|}{ Rodzaj zdarzenia } & $\begin{array}{c}\text { Użycie } \\
\text { autopompy }\end{array}$ & $\begin{array}{c}\text { Zużycie wody } \\
\mathbf{w ~ m}^{\mathbf{3}}\end{array}$ & $\begin{array}{c}\text { Zużycie środka } \\
\text { pianotwórczego w } \mathbf{~ m}^{\mathbf{3}}\end{array}$ \\
\hline Pożar & 72598 & 422496,8 & 309 \\
\hline Miejscowe zagrożenie & 14398 & 21717,6 & 16 \\
\hline
\end{tabular}

Źródło: Dane statystyczne KG PSP [www.kgpsp.gov.pl].

Z powyższych statystyk wynika, że w 2013 roku na terenie Polski zostało zarejestrowanych 375985 zagrożeń, z czego 126426 to pożary, a 249559 to miejscowe zagrożenia. W trakcie zagrożeń użyto 333402 średnich pojazdów ratowniczo-gaśniczych oraz 113422 ciężkich pojazdów ratowniczo-gaśniczych. Przeliczając to na liczbę posiadanych pojazdów, średnio w trakcie 2013 roku każdy ze średnich samochodów ratowniczo-gaśniczych użyty został 442 razy, a ciężki samochód ratowniczo-gaśniczy 171 razy.

W 126426 pożarach w 2013 roku autopompę użyto 72598 razy (57,4\%), zużywając $422496,8 \mathrm{~m}^{3}$ wody oraz $309 \mathrm{~m}^{3}$ środka pianotwórczego (średnio $5,8 \mathrm{~m}^{3}$ przy każdym użyciu). W 249559 miejscowych zagrożeniach w 2013 roku autopompę użyto 14398 razy, zużywając $21717,6 \mathrm{~m}^{3}$ wody oraz $16 \mathrm{~m}^{3}$ środka pianotwórczego (średnio $1,5 \mathrm{~m}^{3}$ przy każdym użyciu). Średnia dzienna liczba zagrożeń w 2013 roku wyniosła 1030, z użyciem autopompy 238. Średnia dzienna liczba użycia średnich i ciężkich pojazdów ratowniczo-gaśniczych wyniosła 1224 .

Przeliczając to na liczbę posiadanych pojazdów, średnio w trakcie 2013 roku w każdym ze średnich i ciężkich samochodów ratowniczo-gaśniczych autopompa użyta została 61 razy. Każda z pomp przepompowała średnio $314 \mathrm{~m}^{3}$ środków gaśniczych (nie licząc napełniania zbiorników). 
Łączny czas działań ratowniczych w pożarach w 2013 roku wyniósł 165394 godziny, a w trakcie miejscowych zagrożeń 458170 godzin. Daje to w sumie 623564 godzin działań ratowniczo-gaśniczych. Średnio każda z autopomp zamontowana w średnim i ciężkim samochodzie ratowniczo-gaśniczym przepracowała w tym czasie ponad 440 roboczogodzin.

Powyższe dane niezaprzeczalnie wskazują na fakt, że sprzęt wykorzystywany w działaniach ratowniczo-gaśniczych jest dość intensywnie użytkowany. Część sprzętu jest oczywiście użytkowana bardziej intensywnie, niż na to wskazują powyższe statystyki. Nie bez znaczenia dla trwałości autopomp jest brak cykliczności pracy, stopnia i czasu obciążenia. Zagrożeń nie da się przewidzieć. Dlatego też niezawodność pracy autopomp w codziennych działaniach ratowniczo-gaśniczych jest tak ważnym czynnikiem.

\section{Rodzaje uszkodzeń autopomp oraz średni czas pomiędzy uszkodzeniami}

Uszkodzenia mogą zostać ogólnie podzielone na dwie grupy:

- spowodowane niewłaściwą obsługą i/lub konserwacją,

- spowodowane złą lub nieodpowiednią jakością wyrobu.

Do awarii spowodowanych niewłaściwą obsługą możemy zaliczyć między innymi:

- brak przepływu cieczy spowodowany zanieczyszczeniem kolektorów ssawnego i/lub tłocznego, źle działającym urządzeniem zasysającym,

- niską wydajność autopompy w wyniku pracy w stanie kawitacji,

- wysokie drgania lub hałas spowodowane zanieczyszczeniem kolektorów ssawnego i/lub tłocznego

- pęknięcie zaworów, rozszczelnienie kolektorów ssawnych i/lub tłocznych, korpusu pompy spowodowane zamarznięciem nieodwodnionego układu w sezonie zimowym,

- wszelkiego rodzaju zatarcia w korpusie pompy lub urządzenia zasysającego spowodowane zbyt długą pracą na sucho, ciałami obcymi (np. kamienie, gruz),

Do awarii spowodowanych złą lub nieodpowiednią jakością wyrobu możemy zaliczyć między innymi:

- niską wydajność autopompy w wyniku nadmiernych oporów w kolektorze ssawnym i/lub tłocznym, uszkodzenia uszczelnienia pompy,

- wysokie drgania lub hałas spowodowane uszkodzeniem połączenia pompy $\mathrm{z}$ silnikiem napędowym, pracą $\mathrm{w}$ stanie kawitacji, uszkodzeniem lub zużyciem łożysk,

- przegrzewanie autopompy spowodowane wyciekiem smaru, nadmiernym zużyciem elementów współpracujących, uszkodzeniem łożysk wirnika, 
- brak możliwości zassania wody spowodowany uszkodzeniem membran urządzenia zasysającego.

Dostępne dane statystyczne nie zawierają informacji na temat rodzajów uszkodzeń oraz częstości ich występowania. Niemożliwe jest określenie czasów pomiędzy tymi uszkodzeniami. Pozyskane informacje pochodzą od producentów autopomp lub producentów wykorzystujących autopompy w swoich konstrukcjach (np. samochodach ratowniczo-gaśniczych). Uszkodzenia spowodowane niewłaściwą obsługą lub konserwacją są najczęstszą przyczyną uszkodzeń autopomp pożarniczych. Uszkodzenia takie jak niska wydajność czy przegrzewanie pompy są ciężkie do zdiagnozowania przez użytkownika z uwagi na brak specjalistycznego wyposażenia oraz krótkotrwałą pracę. Uszkodzenia spowodowane pracą w stanie kawitacji, która jest niekorzystnym i niepożądanym zjawiskiem, mogą doprowadzić do poważnych uszkodzeń (np. rozerwania wirnika). Zjawisko jest zauważalne w czasie badań laboratoryjnych. Jednakże zarówno w czasie działań ratowniczo-gaśniczych, jak i badań laboratoryjnych zjawisko trwa zbyt krótko (przeciwdziała się temu, np. zmniejszając obroty silnika), aby doprowadzić do szybkiego zużycia lub uszkodzenia.

Przegrzewanie i związane z nim uszkodzenia mogą być zauważalne głównie w czasie badań laboratoryjnych i próby wielogodzinnej pracy z wodą w układzie zamkniętym.

\section{Analiza wykorzystania narzędzi hydraulicznych w straży pożarnej}

Komenda Główna Państwowej Straży Pożarnej co roku przygotowuje zestawienie stanu wyposażenia w jednostkach PSP w poszczególnych województwach. Zawiera ono również dane dotyczące narzędzi hydraulicznych wykorzystywanych w Państwowej Straży Pożarnej w kraju z podziałem na poszczególne województwa. Na potrzeby niniejszego opracowania za kryterium podziału przyjęto wartość siły cięcia i rozpierania wyrażoną $\mathrm{w} \mathrm{kN}$.

TABELA 7

Zestawienie ilościowe stanu sprzętu w straży pożarnej w latach 2012-2013

\begin{tabular}{|l|c|c|}
\hline \multirow{2}{*}{ Nazwa wyrobu } & \multicolumn{2}{|c|}{ Liczba sztuk w poszczególnych w latach } \\
\cline { 2 - 3 } & $\mathbf{2 0 1 2}$ & $\mathbf{2 0 1 3}$ \\
\hline $\begin{array}{l}\text { Rozpieracz szczękowy o minimalnej sile } \\
\text { rozpierania mniejszej lub równej 50 kN }\end{array}$ & 343 & 372 \\
\hline $\begin{array}{l}\text { Rozpieracz szczękowy o minimalnej sile } \\
\text { rozpierania powyżej 50 kN }\end{array}$ & 804 & 743 \\
\hline $\begin{array}{l}\text { Nożyce hydrauliczne o maksymalnej sile cięcia } \\
\text { poniżej 300 kN }\end{array}$ & 456 & 470 \\
\hline
\end{tabular}




\begin{tabular}{|l|c|c|}
\hline \multirow{2}{*}{ Nazwa wyrobu } & \multicolumn{2}{c|}{ Liczba sztuk w poszczególnych w latach } \\
\cline { 2 - 3 } & $\mathbf{2 0 1 2}$ & $\mathbf{2 0 1 3}$ \\
\hline $\begin{array}{l}\text { Nożyce hydrauliczne o maksymalnej sile cięcia } \\
\text { równej lub większej 300 kN }\end{array}$ & 920 & 823 \\
\hline $\begin{array}{l}\text { Cylinder rozpierający jednostopniowy o sile } \\
\text { rozpierającej poniżej 120 kN }\end{array}$ & 307 & 336 \\
\hline $\begin{array}{l}\text { Cylinder rozpierający jednostopniowy o sile } \\
\text { rozpierającej równej lub większej 120 kN }\end{array}$ & 1000 & 921 \\
\hline
\end{tabular}

Źródło: Opracowanie własne na podstawie bazy danych KG PSP, www.kgpsp.gov.pl.

W tabeli 7. przedstawiono liczbę i rodzaj sprzętu wykorzystywanego przez PSP. Dane przedstawiono również graficznie na ryc. 7 . Z przedstawionych danych wynika, iż liczba rozpieraczy szczękowych o minimalnej sile rozpierania mniejszej lub równej $50 \mathrm{kN}$ wzrosła z 343 do 372 sztuk, zaś liczba nożyc hydraulicznych o maksymalnej sile cięcia poniżej $300 \mathrm{KN}$ wzrosła z 456 do 470 sztuk. Z kolei liczba cylindrów rozpierających jednostopniowych o sile rozpierającej równej lub większej $300 \mathrm{kN}$ wzrosła z 307 do 336 sztuk. Natomiast liczba rozpieraczy szczękowych o minimalnej sile rozpierania mniejszej lub równej $50 \mathrm{kN}$ zmalała z 804 do 743 sztuk, liczba nożyc hydraulicznych o maksymalnej sile cięcia równej lub powyżej $300 \mathrm{kN}$ zmalała z 920 do 823 sztuk. W przypadku cylindrów rozpierających jednostopniowych o sile rozpierającej równej lub powyżej $120 \mathrm{~N}$ ich liczba zmalała z 1000 do 921 sztuk. Z przedstawionych danych wynika, że Państwowa Straż Pożarna w działaniach ratowniczych wykorzystuje sprzęt o niższych parametrach technicznych, ale o znacznie lepszych parametrach ergonomicznych i funkcjonalnych.

Hydrauliczny sprzęt ratowniczy (nożyce hydrauliczne, rozpieracze hydrauliczne szczękowe, rozpieracze kolumnowe, uniwersalne narzędzia hydrauliczne combi) użytkowane są przez Państwową Straż Pożarną w trudnych i niekiedy ekstremalnych warunkach. Ze względu na charakter prowadzonych działań dla ww. sprzętu stawiane są rygorystyczne wymagania. Należy zauważyć, iż charakter prowadzonych działań wpływa negatywnie na ich maksymalny okres przydatności do użytkowania. Również stosowanie nowych technologii i rozwiązań konstrukcyjnych, np. w pojazdach, wymaga wprowadzania do użytkowania coraz bardziej funkcjonalnych narzędzi hydraulicznych. Z przedstawionych danych wynika, iż PSP posiada coraz więcej sprzętu ratowniczego, jednak w rozbiciu na poszczególne województwa okazuje się, iż w niektórych z nich sprzętu przybyło, a w innych ubyło. Doskonale widać to na przykładzie województw: mazowieckiego, gdzie liczba sprzętu hydraulicznego zmalała, i dolnośląskiego, w którym liczba ta znacząco wzrosła. 


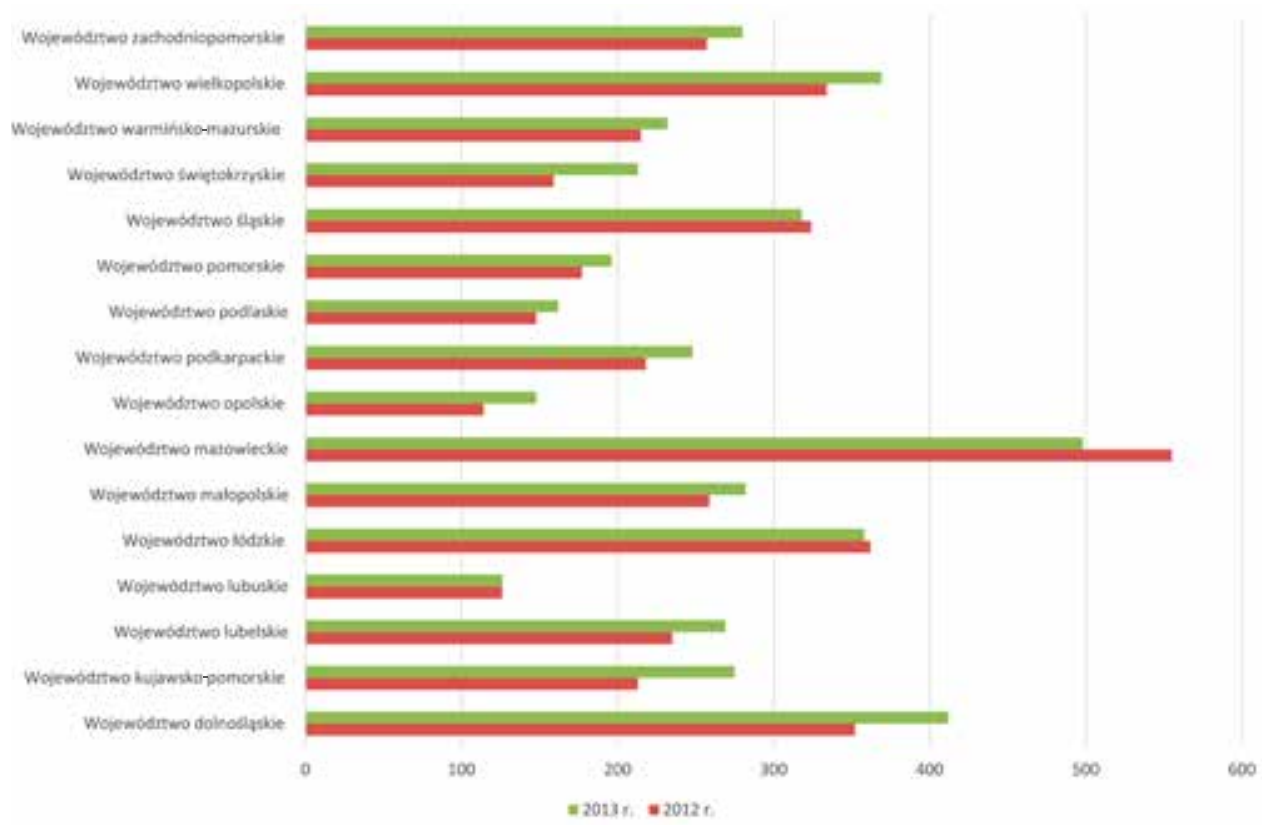

Ryc. 7. Porównanie ilościowego stanu sprzętu w straży pożarnej w latach 2012-2013 z podziałem na jednostki PSP

Źródło: Opracowanie własne na podstawie bazy danych KG PSP [www.kgpsp.gov.pl].

\section{Podsumowanie}

Wyniki projektu są adresowane do jednostek Państwowej Straży Pożarnej. Dzięki jego wdrożeniu możliwe będzie wygenerowanie oszczędności na poziomie poszczególnych jednostek, co powinno przełożyć się na oszczędności w całej służbie, a więc i całej branży. Oprócz tego oczekuje się, że za pomocą monitorowania sprzętu ratowniczego i ratowniczo-gaśniczego możliwe będzie wytypowanie newralgicznych punktów związanych z niezawodnością i jakością tego sprzętu. Powinno to wpłynąć na zwiększenie świadomości użytkowników i producentów, którzy będą starali się doskonalić swoje produkty. Ponadto zainteresowanie pozostałych potencjalnych odbiorców może być wynikiem rosnącej świadomości, w jakich obszarach i w jaki sposób można wykorzystać i skomercjalizować rezultaty niniejszego projektu. Jeśli wyniki projektu okażą się sukcesem, będzie można zaproponować przyjęte w nim rozwiązania systemowe jednostkom straży pożarnej w Unii Europejskiej, a być może także na świecie. 



\title{
WYMAGANIA FUNKCJONALNE \\ DLA SYSTEMU MONITOROWANIA \\ I ANALIZA NIEZAWODNOŚCI EKSPLOATACJI \\ WYBRANYCH ŚRODKÓW WYPOSAŻENIA \\ PAŃSTWOWEJ STRAŻY POŻARNEJ
}

\author{
Janusz Kręcikij \\ Dawid Rzemek
}

\section{Wprowadzenie}

Państwowa Straż Pożarna (PSP) stanowi jedną z wiodących służb mających wpływ na poprawne funkcjonowanie niezwykle istotnego dla bezpieczeństwa publicznego państwa Systemu Zarządzania Kryzysowego. Wbrew nazwie jej działalność nie sprowadza się jedynie do reagowania na zdarzenia nagłe i miejscowe, lecz stanowi trzon zarówno operacyjny, jak i logistyczny krajowego systemu ratowniczo-gaśniczego. Odpowiednio wyszkolony personel, właściwe rozwiązania strukturalno-organizacyjne i specjalistyczne jednostki sprzętowe (JS) mają znaczący wpływ na skuteczność działań Państwowej Straży Pożarnej. Nie bez znaczenia są również rozwiązania informatyczne kontrolujące stan techniczny sprzętu, które dla tak ważnej organizacji w strukturze państwa powinny być wyspecjalizowane i indywidualnie skonstruowane. Zapewnienie ciągłości monitorowania i analizy parametrów JS umożliwi wykorzystanie całkowitego potencjału sprzętowego, którym dysponuje PSP. Nieustająca aktualizacja danych ilościowych i jakościowych będzie miała udział w poszerzaniu świadomości sytuacyjnej dowódców akcji, osób operacyjnych $(\mathrm{OO})$ i osób logistycznych $(\mathrm{OL})$ na poszczególnych szczeblach organizacyjnych PSP.

\section{Metody}

Do osiągnięcia celu, którym jest określenie wymagań funkcjonalnych dla systemu monitorowania i analizy niezawodności eksploatacji wybranych środków wyposażenia PSP, zastosowano techniki badawcze należące do grupy metod teoretycznych. Przeanalizowano dokumenty formalne (regulaminy, instrukcje, rozporządzenia, decyzje) oraz prace naukowo-badawcze traktujące o monitorowaniu stanu ilościowego i technicznego sprzętu. W wydobywaniu podobieństw i różnic w specyfice 
potrzeb $\mathrm{w}$ aspektach operacyjnym i logistycznym pomocne było wykorzystanie porównania. Poszukiwanie podobieństw badanych potrzeb ułatwione zostało poprzez zastosowanie wnioskowania. Specyfika wstępnie rozpoznanego materiału badawczego wskazała na konieczność stosowania schematu wnioskowania, w którym prawdziwość przesłanek nie przesądza o prawdziwości wniosku. Uogólnienie zostało wykorzystane do ujawnienia cech i zjawisk powtarzalnych, szczególnie w zakresie rodzajów informacji z punktu widzenia operacyjnego i logistycznego, prowadząc do wygenerowania wymagań funkcjonalnych dotyczących monitoringu eksploatacji sprzętu. Działania te umożliwiły zidentyfikowanie potrzeb wynikających ze specyfiki funkcjonowania PSP i zaprojektowanie koncepcji Systemu Monitorowania Stanu Technicznego (SMST).

\section{Wyniki}

System monitorowania stanu technicznego wybranych typów sprzętu PSP (SMST) wykorzystywany będzie na następujących poziomach funkcjonowania straży pożarnej (ryc. 1):

- poziom krajowy (Komenda Główna PSP),

- poziom wojewódzki (komendy wojewódzkie PSP),

- poziom powiatowy (komendy powiatowe i miejskie PSP),

- jednostki ratowniczo-gaśnicze PSP (w tym JRG ośrodków szkoleniowych),

- dowódcy akcji ratowniczych w miejscu prowadzenia działań ratowniczych.

Na poziomie krajowym, wojewódzkim i powiatowym beneficjentami systemu będą:

- komendanci - w celu zapewnienia świadomości sytuacyjnej w zakresie rzeczywistego wykorzystywania potencjału PSP,

- osoby funkcyjne odpowiedzialne za prowadzenie działań operacyjnych PSP (OO),

- osoby funkcyjne odpowiedzialne za zabezpieczenie logistyczne funkcjonowania PSP (OL).

W przypadku prowadzenia akcji ratowniczej najważniejszą osobą wykorzystującą system będzie dowódca akcji. W oparciu o informacje w czasie rzeczywistym dowódca będzie mógł poddawać analizie następujące kwestie:

- rozmieszczenie jednostek sprzętowych w konkretnych lokalizacjach,

- sprawność lub niesprawność (awaria, uszkodzenie) konkretnych jednostek sprzętowych. 


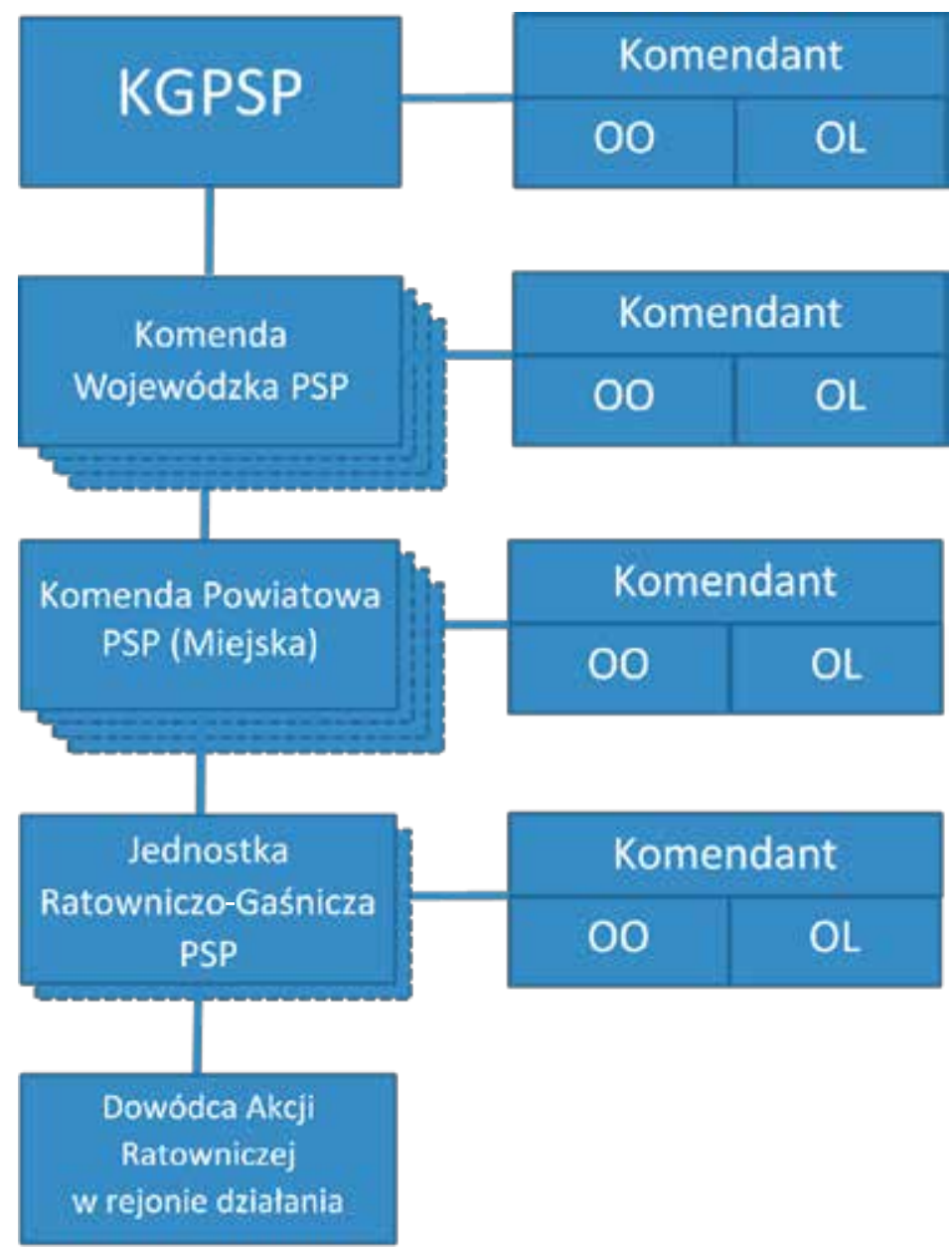

Ryc. 1. Użytkownicy systemu monitorowania stanu technicznego wybranego sprzętu PSP Źródło: Opracowanie własne.

\section{Dowódca akcji ratowniczej}

Głównym założeniem na tym poziomie jest nieobciążanie dowódcy akcji zbędną informacją, to znaczy taką, która nie ma znaczenia w chwili prowadzenia działań w terenie. Dlatego dowódca akcji powinien posiadać urządzenie przenośne, na którym na tle mapy terenu (lub planu miasta) widoczne będą aktualne informacje o monitorowanych jednostkach sprzętowych prezentowane w postaci właściwych znaków operacyjnych PSP. Miejsce znaku na mapie (planie) odpowiadać ma jego rzeczywistej lokalizacji. Sensory zainstalowane na urządzeniu (niezależnie od gromadzenia założonych informacji o wybranych parametrach pracy) powinny gwarantować 
przekazanie dowódcy prostej informacji: dana jednostka sprzętowa „sprawna” lub "niesprawna”, co na urządzeniu przenośnym widoczne będzie w postaci zielonego (sprawna) lub czerwonego (niesprawna) wypełnienia znaku operacyjnego (ryc. 2). Dodatkowo po dotknięciu znaku powinna rozwijać się informacja wskazująca dokładne współrzędne geograficzne jednostki sprzętowej oraz jej oznaczenie katalogowe (inwentarzowe) zgodnie z zasadami opisów sprzętu obowiązującymi w PSP.

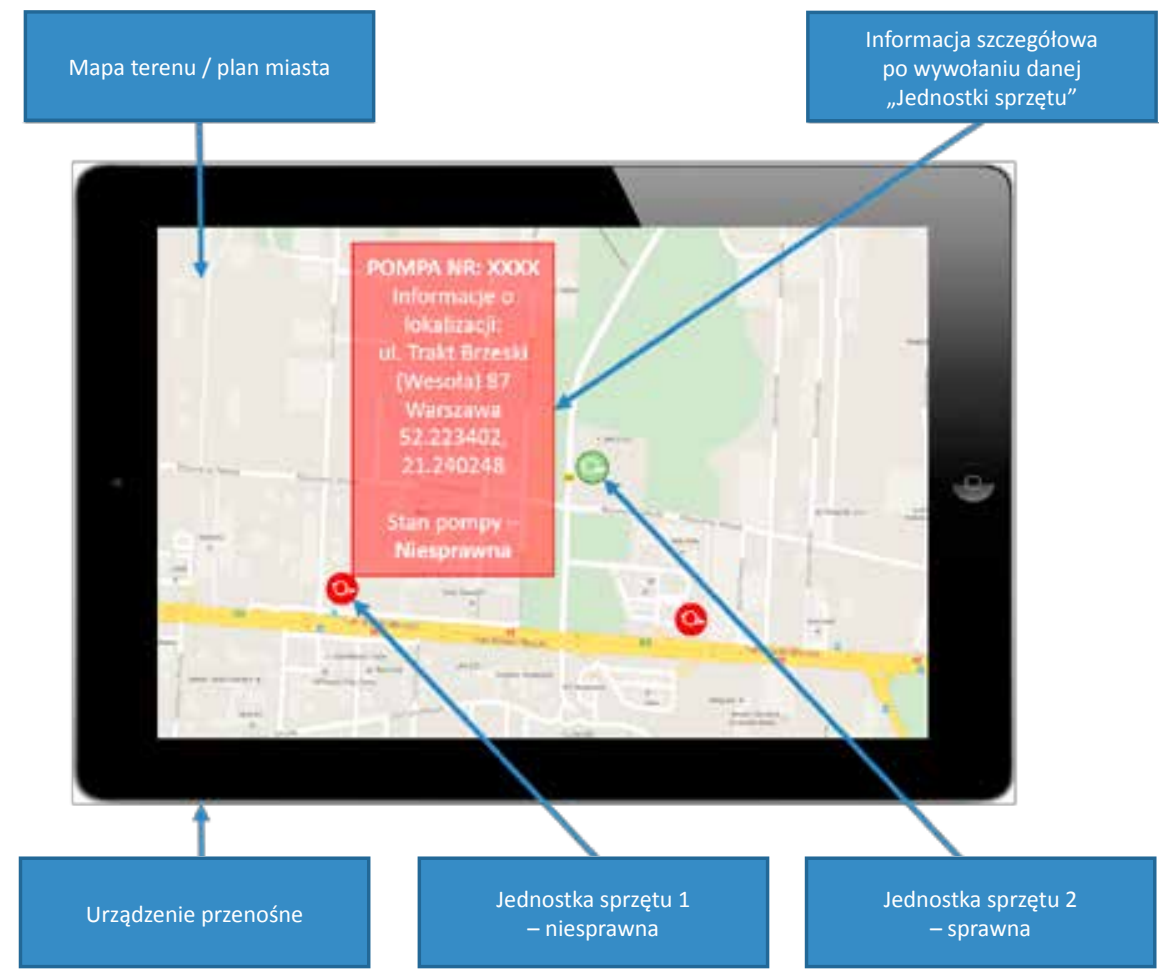

Ryc. 2. Idea sposobu przekazywania informacji ważnych dla dowódcy akcji ratowniczej Źródło: Opracowanie własne.

\section{Jednostki ratowniczo-gaśnicze i komendy PSP szczebla powiatowego (miejskiego), wojewódzkiego oraz krajowego}

System stworzony na potrzeby jednostek ratowniczo-gaśniczych i komend PSP powinien zapewniać dostęp, w sposób prosty i intuicyjny, uprawnionych osób funkcyjnych do zarchiwizowanych informacji zgromadzonych na podstawie danych z sensorów. Informacje mają być dostępne za pośrednictwem aplikacji wykorzystującej i interpretującej dane z bazy danych niezależnego systemu monitorowania stanu technicznego. System ma być wykorzystywany do tworzenia raportów i prezentacji graficznej informacji z jednostek sprzętowych. 
Ze względu na brak możliwości ingerencji w wykorzystywany w PSP system wspomagania dowodzenia (SWD-ST) konieczne jest posiadanie przez system autonomicznego podsystemu baz danych, dzięki któremu na każdym poziomie dowodzenia Państwowej Straży Pożarnej możliwy będzie wgląd w dotychczasową historię pracy i rzeczywisty stan techniczny każdego monitorowanego przez system urządzenia stosownie do potrzeb operacyjnych i logistycznych.

Tego rodzaju podsystem baz danych SMST powinien zapewniać gromadzenie i możliwość dostępu uprawnionych osób funkcyjnych do zarchiwizowanych informacji, przy czym dane z poziomu podrzędnego powinny być automatycznie sumowane w centralnej bazie danych SMST. Informacje należałoby zagregować w dwóch grupach problemowych (modułach): operacyjnym i logistycznym (ryc. 3).

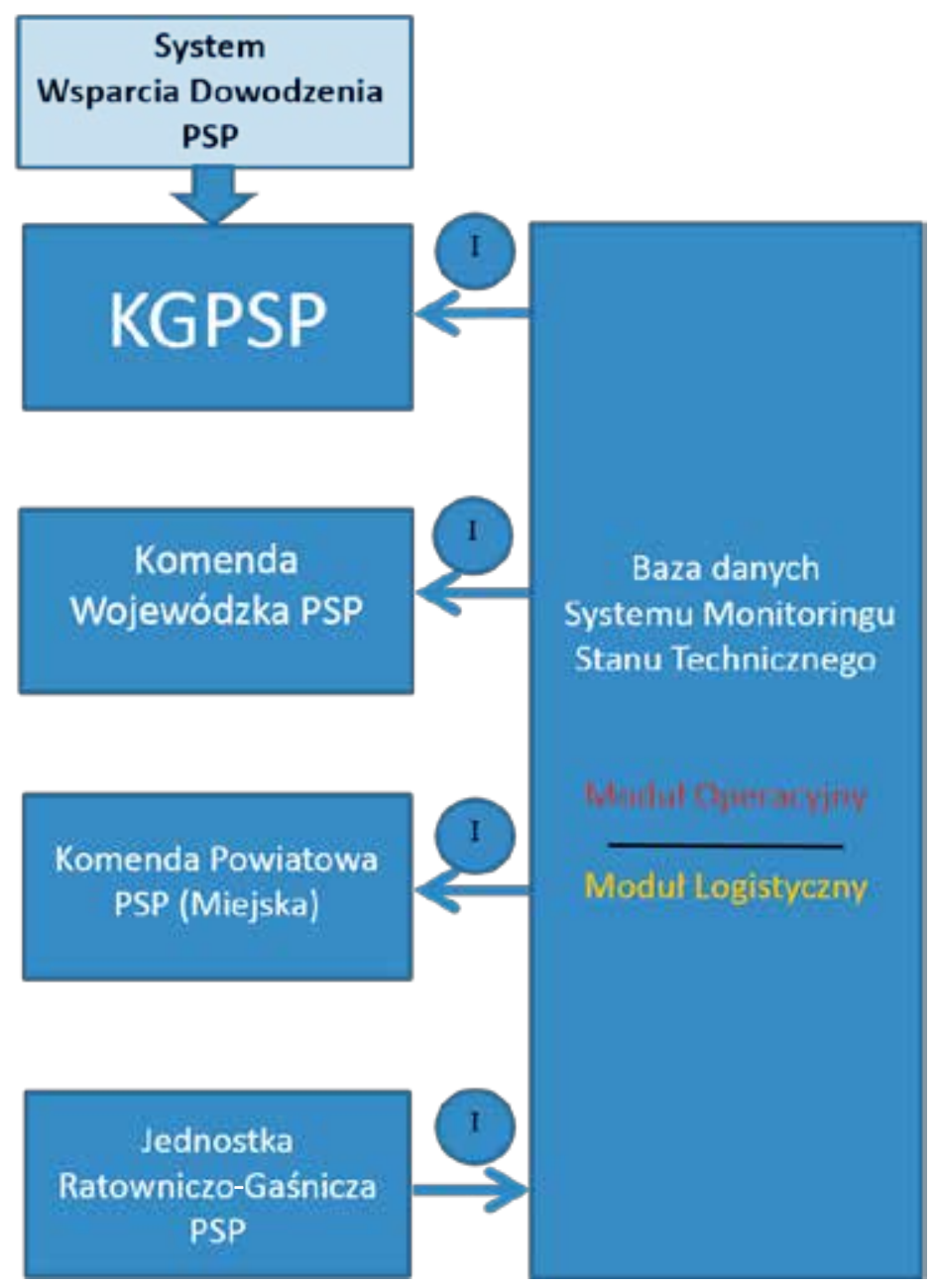

Ryc. 3. Idea wykorzystania baz danych systemu na wszystkich poziomach dowodzenia Źródło: Opracowanie własne. 
Operacyjna grupa danych powinna obejmować informacje dotyczące każdej monitorowanej jednostki sprzętowej:

- miejsca wykorzystania monitorowanego sprzętu (ostatnie i poprzednie), z możliwością prezentacji opisowej (współrzędne geograficzne) i graficznej - z wykorzystaniem mapy i znaków operacyjnych PSP,

- czasu wykorzystania sprzętu,

- sprawności sprzętu (w kategoriach sprawny, niesprawny) w konkretnej akcji ratowniczej,

- sprawności grupy sprzętu (w \%) w konkretnej akcji ratowniczej i sumarycznie dla danej grupy sprzętu oraz struktury PSP.

Usługa ta pozwoli uprawnionym osobom funkcyjnym:

- pod względem operacyjnym na pogłębienie świadomości operacyjnej o rzeczywistym wykorzystaniu poszczególnych jednostek sprzętowych,

- na poszerzenie wiedzy o rzeczywistym wykorzystaniu konkretnego sprzętu w działaniach ratowniczych, w rodzajach działań i miejscach akcji,

- na dokonywanie analiz i uogólnień co do potrzeb i stopnia wykorzystywania poszczególnych jednostek sprzętowych w czasie i przestrzeni.

Logistyczna grupa danych powinna obejmować informacje dotyczące każdej monitorowanej jednostki sprzętowej, podobnie jak dla potrzeb operacyjnych, poszerzone jednak o:

- czas wykorzystania monitorowanej jednostki sprzętowej (MJS) w poszczególnych akcjach ratunkowych,

- całkowity czas wykorzystania MJS,

- czas pozostały do remontu MJS (zgodnie z zaleceniami eksploatacyjnymi),

- przewidywany czas wycofania z użytku MJS (zgodnie z zaleceniami eksploatacyjnymi),

- liczbę dotychczasowych awarii MJS,

- rodzaje dotychczasowych awarii MJS,

- możliwość grupowania powyższych informacji wg:

- typów sprzętu (np. pompa typu XYZ),

- struktury organizacyjnej PSP (w JRG, w skali powiatu, w skali województwa, w skali kraju, w konkretnej komendzie powiatowej i wojewódzkiej),

- czasu.

Usługa ta pozwoli uprawnionym osobom funkcyjnym pod względem logistycznym na podniesienie poziomu świadomości sytuacyjnej w zakresie:

- szczegółowej wiedzy o stopniu zużycia sprzętu,

- szczegółowej wiedzy o stopniu sprawności sprzętu, w tym konkretnych jego rodzajów,

- zapewni możliwość racjonalnego planowania remontów dzięki kompleksowej wiedzy w tym zakresie,

- stworzy możliwości racjonalnego planowania zakupów. 
Istotę funkcjonowania SMST przedstawia ryc. 4.

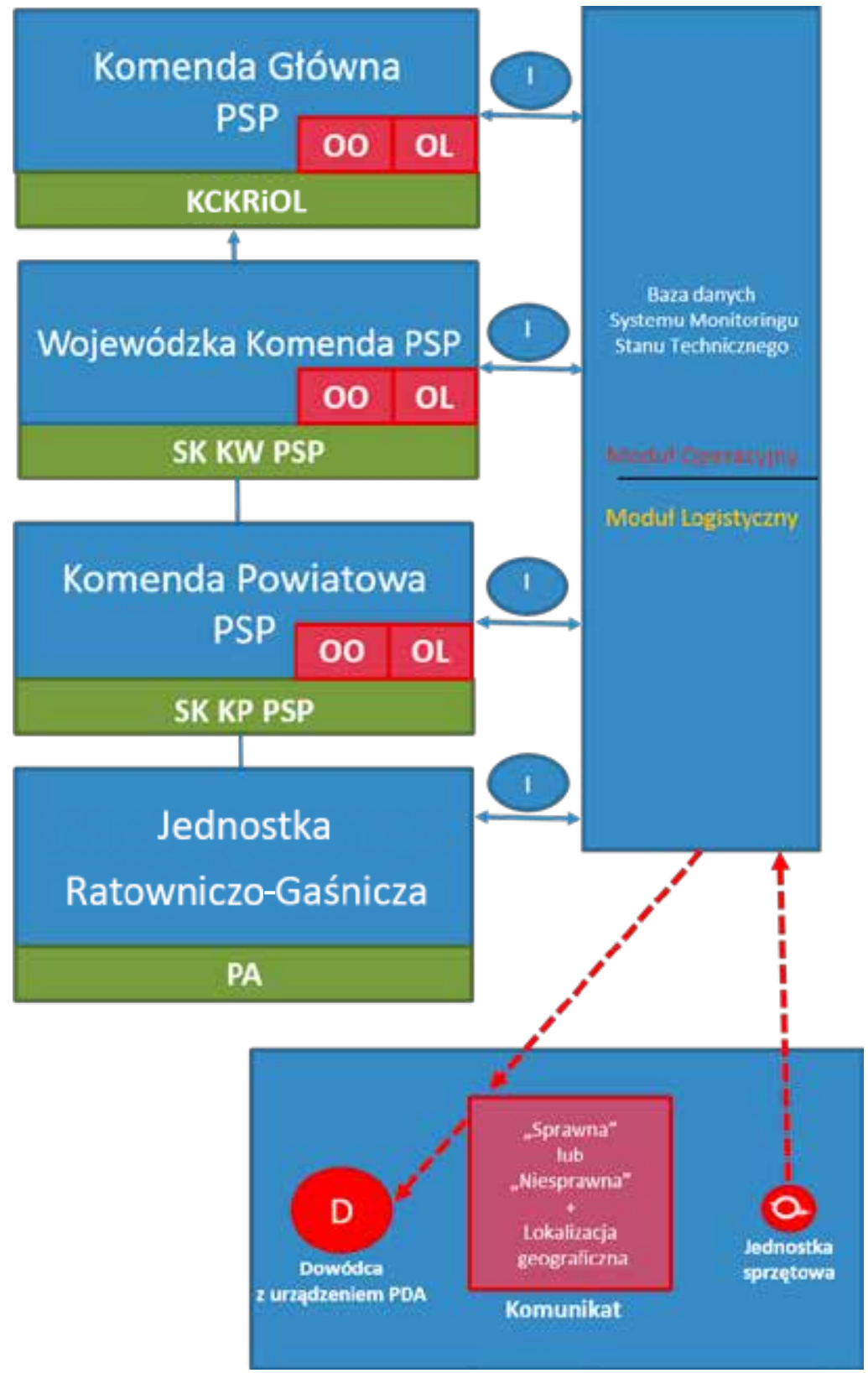

Ryc. 4. Istota wykorzystania SMST na poszczególnych poziomach dowodzenia PSP Źródło: Opracowanie własne.

Istotę graficznego zobrazowania idei zastosowania komponentów systemu przedstawia ryc. 5. 


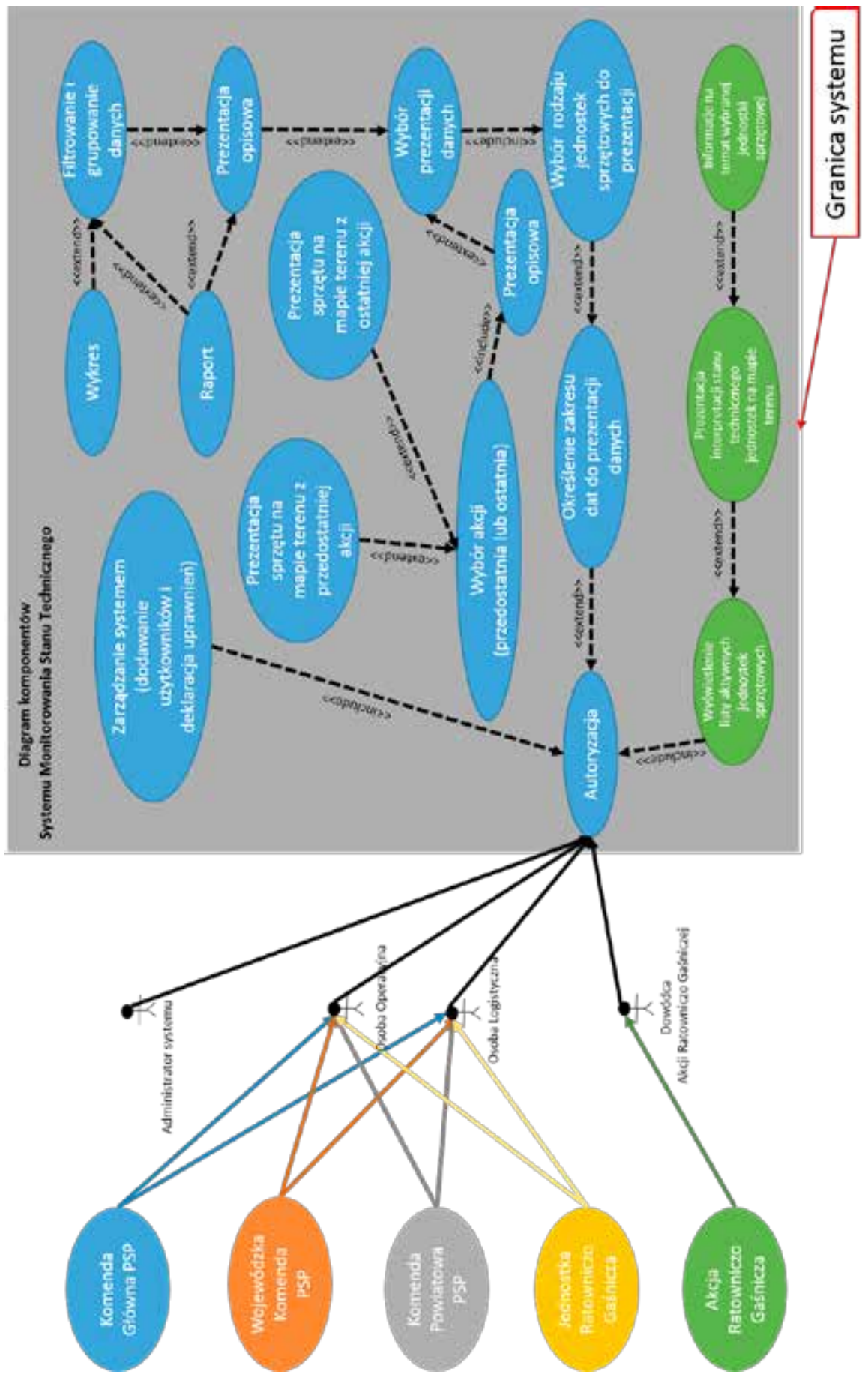

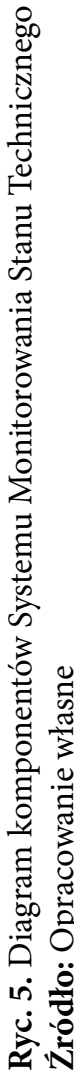




\section{Podsumowanie i wnioski}

W wyniku ciągłego dążenia do zapewnienia wysokiej jakości bezpieczeństwa obywatelskiego Państwowa Straż Pożarna zobowiązana jest do nieustannego udoskonalania dotychczas używanych rozwiązań operacyjnych i logistycznych. Poprawne zdefiniowanie założeń dotyczących strategii funkcjonowania jednostek operacyjno-logistycznych wpłynie na usprawnienie procesu decyzyjnego na poziomie OO i OL oraz zwiększenie świadomości operacyjnej dowódców akcji. Wiedza dostarczana na podstawie automatycznie generowanych raportów do poszczególnych szczebli PSP pozwala na racjonalne zarządzanie JS oraz zapleczem finansowym. Umożliwia to zaplanowanie ogółu czynności związanych z eksploatacją, serwisowaniem, kreowaniem wymagań funkcjonalnych, by w efekcie pomóc przy podejmowaniu decyzji o nabyciu nowego sprzętu.

Innowacyjna koncepcja SMST jest niezwykle cenna dla całokształtu funkcjonowania PSP - pozwala ona na wykorzystanie całego potencjału każdej z JRG. Przewagą systemu SMST nad dotychczasowymi rozwiązaniami systemowymi jest brak konieczności angażowania pracowników do ręcznego analizowania danych na temat parametrów wykorzystywanego sprzętu. Informacje te są automatycznie eksportowane przez sensory i importowane do bazy danych systemu monitoringu. Tym sposobem w czasie rzeczywistym dowódca akcji jest w stanie podjąć racjonalną i opartą na wiarygodnych danych decyzję o konieczności wezwania wsparcia sprzętowego, przy jednoczesnym braku konieczności informowania przełożonych o postępach akcji, ponieważ mają oni równoległy dostęp do tych samych zinterpretowanych przez system materiałów. 



\title{
BEZPIECZEŃSTWO TRANSMISJI DANYCH W SYSTEMACH MONITOROWANIA WYPOSAŻENIA STRAŻY POŻARNEJ
}

\author{
Łukasz Apiecionek \\ Rafał Motylewski \\ Paweł Stosik
}

\section{Wprowadzenie}

W ramach czwartego konkursu NCBR na rzecz Obronności i Bezpieczeństwa Państwa realizowany jest projekt rozwojowy numer DOBR-BIO4/051/13087/2013 pn. „Opracowanie metodologii stałego nadzoru eksploatacji wybranych obszarów wyposażenia straży pożarnej w zakresie niezawodności i skuteczności działania”. Celem projektu jest stworzenie zaawansowanych technologii informatycznych, wspomagających zarządzanie kryzysowe i ratownictwo, stworzenie demonstratora technologii - systemu teleinformatycznego zbierającego i przetwarzającego dane oraz wspierającego zadania logistyczne w zakresie serwisowania oraz zakupów sprzętu ratowniczego, a także zawierającego bazę świadectw dopuszczenia wydawanych przez Centrum Naukowo-Badawcze Ochrony Przeciwpożarowej Państwowy Instytut Badawczy. Zgodnie z wytycznymi dla projektu opracowany demonstrator technologii systemu zostanie zainstalowany i sprawdzony w warunkach operacyjnych.

W skład przedmiotowego systemu wejdą:

- serwer aplikacji, stanowiący jego punkt centralny;

- modularna aplikacja kliencka pozwalająca na dostęp do systemu oraz interfejs WWW umożliwiający dostęp do systemu przy pomocy przeglądarki internetowej;

- konsole operatorskie: cztery stacjonarne znajdujące się w centrum dowodzenia oraz dwie zdalne umożliwiające bieżący monitoring floty podczas akcji.

Planowana architektura omawianego systemu została przedstawiona na ryc. 1. 


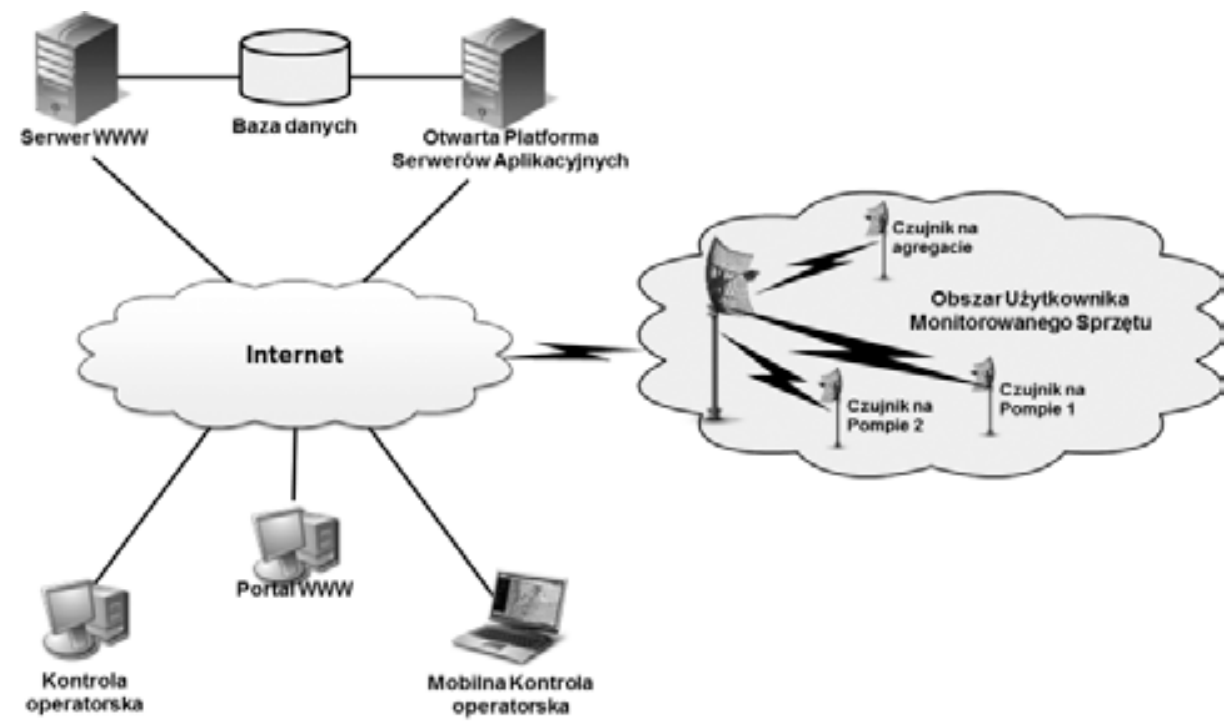

Ryc. 1. Architektura systemu

Źródło: Wniosek nr 13087 „Monitoring”.

Końcowym produktem niniejszego projektu będzie demonstrator systemu diagnostyki technicznej wyposażenia straży pożarnej. Na elementy demonstratora będą się składały:

- system sensorów monitorujący stan wybranych urządzeń;

- system łączności pozwalający na:

- przesyłanie na bieżąco w warunkach operacyjnych danych pozyskanych z sensorów do systemu informatycznego,

- zdalny dostęp do stworzonego systemu;

- system informatyczny zbierający i przetwarzający dane oraz wspierający zadania logistyczne w zakresie serwisowania oraz zakupu sprzętu ratowniczego.

Przedstawione rozwiązanie zostanie poddane analizie pod kątem bezpieczeństwa całego projektu i jego użyteczności.

\section{Identyfikacja i wybór środków łączności}

Budowany demonstrator technologii musi spełniać warunki docelowej pracy systemu, mianowicie ${ }^{1}$ :

- posiadać system łączności pozwalający na przesyłanie na bieżąco w warunkach operacyjnych danych pozyskanych z sensorów do systemu informatycznego oraz umożliwiający zdalny dostęp do stworzonego systemu;

- zapewniać mobilność monitorowanych stacji;

- umożliwić przesył danych z wysoką jakością transmisji i niską stopą błędów;

1 Wniosek nr 13087 „Monitoring”. 
- dostarczyć możliwości dostępu zdalnego do poszczególnych urządzeń budowanego systemu, celem zbierania danych, rekonfiguracji i monitorowania działania;

- gwarantować niezawodność połączeń - m.in. stabilność łączy i pewność działania;

- zapewniać odpowiednią prędkość transmisji z uwzględnieniem wielkości danych koniecznych do przesyłania;

- gwarantować niezbędne zasięgi komunikacji pomiędzy jednostkami;

- transmisję danych z wykorzystaniem protokołu IP.

Wybrane środki łączności muszą gwarantować osiągnięcie wymaganych parametrów do pracy systemu. Dlatego ich identyfikacja przebiegała pod kątem spełniania odpowiednich wymogów. W ramach prac zbadano i wybrano możliwe do zastosowania środki łączności. Uwzględniając wszystkie czynniki, na podstawie wcześniej dokonanych analiz i badań parametrów wybranych środków łączności, wykonano macierz, która pozwala określić przydatność technologii transmisji do zastosowania w realizowanym projekcie.

Tabela 1

Podsumowanie charakterystyki wybranych środków łączności

\begin{tabular}{|c|c|c|c|c|c|c|}
\hline Lp. & Środek łączności & $\begin{array}{c}\text { Koszt } \\
\text { zakupu }\end{array}$ & $\begin{array}{c}\text { Koszt } \\
\text { eksploatacji }\end{array}$ & $\begin{array}{c}\text { Zasięg } \\
\text { transmisji }\end{array}$ & $\begin{array}{c}\text { Prędkość } \\
\text { transmisji }\end{array}$ & Inne \\
\hline 1. & $\begin{array}{l}\text { Radiostacje } \\
\text { SpearNet }\end{array}$ & Wysoki & Niski & Średni & Średnia & $\begin{array}{l}\text { Wymagają } \\
\text { częstotliwo- } \\
\text { ści do pracy }\end{array}$ \\
\hline 2. & $\begin{array}{l}\text { Moduły WLAN } \\
\text {-łączność } 802.11\end{array}$ & Niski & Niski & Mały & Duża & - \\
\hline 3. & $\begin{array}{c}\text { Radiostacje F@ } \\
\text { stNet } 9311\end{array}$ & Wysoki & Niski & Duży & Mała & $\begin{array}{l}\text { Wymagają } \\
\text { częstotliwo- } \\
\text { ści do pracy }\end{array}$ \\
\hline 4. & $\begin{array}{c}\text { Terminal sateli- } \\
\text { tarny EXPLORER }\end{array}$ & Średni & Wysoki & Bez ograniczeń & Duża & - \\
\hline 5. & $\begin{array}{c}\text { Radiostacje UKF } \\
\text { PR4G }\end{array}$ & Wysoki & Niski & Duży & Mała & $\begin{array}{l}\text { Wymagają } \\
\text { częstotliwo- } \\
\text { ści do pracy }\end{array}$ \\
\hline 6. & $\begin{array}{c}\text { Radiostacje RKS } \\
8000\end{array}$ & Wysoki & Niski & Bardzo duży & Mała & $\begin{array}{l}\text { Wymagają } \\
\text { częstotliwo- } \\
\text { ści do pracy }\end{array}$ \\
\hline 7. & $\begin{array}{l}\text { Radiostacje RRC } \\
9210 \text { i 9310AP }\end{array}$ & Wysoki & Niski & Duży & Mała & $\begin{array}{l}\text { Wymagają } \\
\text { częstotliwo- } \\
\text { ści do pracy }\end{array}$ \\
\hline 8. & $\begin{array}{c}\text { Radiostacje } \\
\text { HCDR }\end{array}$ & Wysoki & Niski & Duży & Średnia & $\begin{array}{l}\text { Wymagają } \\
\text { częstotliwo- } \\
\text { ści do pracy }\end{array}$ \\
\hline 9. & CDMA/3G/LTE & Niski & Średni & Prawie cały kraj & Duża & - \\
\hline
\end{tabular}

Źródło: Sprawozdanie częściowe z zadania badawczego 15011210 projektu „Monitoring” - Identyfikacja i rozpoznanie możliwych do wykorzystania środków transmisyjnych. 
Jak wynika z powyższej tabeli, w celu umożliwienia pracy systemu z małym kosztem budowy i eksploatacji, przy jednoczesnej pracy na terenie kraju, najlepszym rozwiązaniem jest zapewnienie łączności CDMA/3G/LTE pomiędzy jednostkami mobilnymi a centrum dowodzenia, przy równoczesnej transmisji Wi-Fi w obrębie monitorowanej jednostki.

\section{Analiza protokołów transmisji danych}

Podczas analiz wybranych potencjalnych środków łączności zidentyfikowano i przedstawiono następujące protokoły transmisji danych możliwe do zastosowania w projekcie2:

- IP (ang. Internet Protocol);

- UDP (ang. User Datagram Protocol);

- TCP (ang. Transmission Control Protocol).

Wybrane protokoły transmisji danych wraz z odpowiednimi środkami łączności muszą gwarantować osiągnięcie wymaganych parametrów do pracy systemu. Protokół $\mathrm{UDP}^{3}$ jest zazwyczaj wykorzystywany przez programy, które służą do jednorazowego przesyłania małych ilości danych lub mają wymagania dotyczące czasu rzeczywistego, np. rozmowy telefoniczne w telefonii Voice over Internet Protocol. W takich przypadkach niskie wymagania protokołu UDP są bardziej przydatne niż funkcje protokołu TCP4.

$\mathrm{W}$ poniższej tabeli przedstawiono porównanie połączeń IP w zależności od tego, czy do transportowania danych jest używany protokół UDP, czy protokół TCP.

TABELA 2

Porównanie protokołów UDP i TCP

\begin{tabular}{|c|c|}
\hline UDP & TCP \\
\hline bezpołączeniowy & połączeniowy \\
\hline $\begin{array}{c}\text { nie gwarantuje dostarczenia, potwierdzania } \\
\text { i szeregowania danych }\end{array}$ & $\begin{array}{c}\text { gwarantuje dostarczenie, potwierdzanie } \\
\text { i szeregowanie danych }\end{array}$ \\
\hline Szybki, mały narzut danych & Wolny, duży narzut danych \\
\hline Transmisja do wielu użytkowników & Transmisja jeden do jeden \\
\hline
\end{tabular}

Źródło: Sprawozdanie częściowe z zadania badawczego 15011210 projektu „Monitoring” - Analiza protokołów wymiany danych na łączach radiowych.

2 Sprawozdanie częściowe z zadania badawczego 15011210 projektu „Monitoring” - Identyfikacja i rozpoznanie możliwych do wykorzystania środków transmisyjnych; http://swiatlan.pl/protokoly/ protokol-ip.html, [Dostęp: 23.07.2014]; http://technet.microsoft.com/pl-pl/library/cc785220(v=ws.10). aspx, [Dostęp: 23.07.2014].

3 W.R. Stevens, UNIX: programowanie usług sieciowych, WNT, Warszawa 2002; D. Comer, Sieci komputerowe: intersieci, WNT, Warszawa 2000; B. Hallberg, Sieci komputerowe, kurs podstawowy, Edition2000, Kraków 2001.

4 D.E. Comer, Sieci komputerowe TCP/IP. Zasady, protokoly i architektura, WNT, Warszawa 1997; C. Hunt, TCP/IP - administracja sieci, Oficyna Wydawnicza Read Me, Warszawa 1996; K. Nowicki, J. Woźniak, Sieci LAN, MAN, WAN - protokoły komunikacyjne, Wydawnictwo Postępu Technicznego, Kraków 1998; Sprawozdanie częściowe z zadania badawczego 15011210 projektu „Monitoring” - Eksperymenty badawcze nowych technologii. 
W przedstawianym projekcie logiczny i zasadny wydaje się wybór protokołów:

- IP - ze względu na konieczność integracji z siecią stacjonarną;

- UDP lub TCP - do transmisji danych w zależności od: wybranego środka łączności, mocy obliczeniowej i pamięci RAM zespołu czujników danych do monitorowania urządzeń straży pożarnej, liczby danych do przesłania i dostępnego pasma oraz konieczności kontroli przesyłanych danych na poziomie protokołu lub aplikacji.

Ze względu na zebrane cechy protokołów wymiany danych, korzystne wydaje się być wybranie w tym zakresie protokołu UDP i zapewnienie gwarancji dostarczenia danych do odbiorcy na poziomie aplikacji.

\section{Bezpieczeństwo systemu}

Ze względu na charakter pracy omawianego systemu - mianowicie wykorzystanie sieci publicznej Internet jako medium transmisyjnego, system staje przed poważnym problemem zapewnienia bezpieczeństwa. Architektura systemu musi zostać poddana dalszej analizie pod kątem jego zabezpieczenia odnośnie wymiany danych na styku sieci ${ }^{5}$ oraz zabezpieczenia przed potencjalnymi atakami z sieci publicznej, które mogą zablokować jej działanie ${ }^{6}$. W tym celu dokonano przeglądu architektur bezpiecznych sieci teleinformatycznych pod kątem wykorzystania dobrych praktyk w budowanym systemie ${ }^{7}$.

Obecnie najczęściej planowanym rozwiązaniem służącym do kontroli są bramy bezpiecznej wymiany informacji IEG (and. Information Exchange Gateway). Ponieważ $\mathrm{w}$ budowanym systemie kwestia rodzaju udostępnianych danych dla różnego poziomu klauzuli sieci nie musi być rozważana, tego typu bramy nie muszą być zastosowane. Być może w przyszłości pojawi się konieczność połączenia systemu monitorowania $z$ innym systemem i kontroli przepływu danych, jednakże w chwili obecnej taka konieczność nie występuje. W związku z tym należy wziąć pod uwagę pozostałe dobre rozwiązania w tym zakresie:

- utworzenie strefy zdemilitaryzowanej DMZ (ang. Demilitarizied Zone);

- zastosowania ściany ogniowej;

5 Ł. Apiecionek, M. Romantowski, J. Śliwa, B. Jasiul, R. Goniacz, Safe Exchange of Information for Civil-Military Operations, MCC 2011: Military Communications and Information Systems Conference, Amsterdam, 17-18.10.2011, w: Military Communications and Information Technology: A Comprehensive Approach Enabler, M. Amanowicz (red.), Redakcja Wydawnictw Wojskowej Akademii Technicznej, Warszawa 2011, s. 39-50 (MK-312); Ł. Apiecionek, M. Romantowski, Secure IP Network Model, "Computational Method in Science and Technology" 4 (2013), s. 209-213.

6 Ł. Apiecionek, J. Czerniak, H. Zarzycki, Protection Tool for Distributed Denial of Services Attack, Beyond Databases, Architectures, and Structures Communications, "Computer and Information Science" Volume 424, 2014, 405-414.

7 Ł. Apiecionek, M. Romantowski, Security solution for Cloud Computing, "Journal of Information, Control and Management Systems" 2 (2013), 51-61. 
- zaimplementowanie mechanizmów wykrywania włamań i intruzów IDS/IPS (ang. Intrusion Detection System/Intrusion Prevention System).

W strefie zdemilitaryzowanej powinny pracować wszystkie serwery, które mają być dostępne z zewnątrz systemu, z sieci publicznej. Pozostałe elementy sieci powinny pracować $\mathrm{w}$ innej strefie, niedostępnej z sieci publicznej. Ponieważ w przygotowywanym demonstratorze w sieci wewnętrznej będzie pracowało tylko kilka konsol operatorskich, nie ma na tym etapie potrzeby budowy takiej strefy. Natomiast zastosowanie ściany ogniowej jest już obecnie konieczne. Ściana ogniowa powinna być tak skonfigurowana, aby z sieci publicznej możliwy był dostęp tylko do określonego adresu IP i tylko na określone porty wybranego protokołu, na których będzie nasłuchiwał serwer. $\mathrm{W}$ takim rozwiązaniu chronione są również konsole operatorskie w sieci wewnętrznej, gdyż dostęp do nich jest zablokowany przez odpowiednią konfigurację ściany ogniowej. Dobrą praktyką w tym przedmiocie jest obecnie stosowanie rozwiązań typu IDS/IPS, aby w dozwolonym ruchu sieciowym wykrywać próby włamań, czy działanie złośliwego oprogramowania. Rozwiązanie to musi jednak współpracować ściśle ze ścianą ogniową i w przypadku wykrycia niepożądanego działania, dany ruch powinien być zablokowany.

Ponadto połączenie środków łączności do serwera powinno wymagać ich uwierzytelniania. Jedną z możliwości jest budowa Infrastruktury Klucza Publicznego (ang. Public Key Infrastructure - PKI). W tym rozwiązaniu urządzenia otrzymują swój certyfikat, który jest potwierdzany przez Centrum Autoryzacji i za jego pomocą mogą przedstawiać się w momencie połączenia do serwera. Budowa PKI wymaga jednak nakładów i definicji polityk bezpieczeństwa. Na etapie demonstratora wydaje się być wystarczające zastosowanie mechanizmów do uwierzytelniania za pomocą hasła współdzielonego. Natomiast konstrukcja oprogramowania powinna przewidywać rozbudowę mechanizmu uwierzytelniania.

Dostęp użytkowników do systemu powinien być możliwy do rozliczenia, co oznacza, że system powinien posiadać mechanizm logowania za pomocą unikalnego loginu i hasła. Ponadto informacje o zalogowaniu i wylogowaniu użytkownika powinny być przechowywane $\mathrm{w}$ dzienniku zdarzeń systemu. W zależności od zastosowanych systemów operacyjnych mogą one dostarczać takowe mechanizmy bez konieczności dodatkowego nakładu prac.

\section{Podsumowanie}

W niniejszym opracowaniu przedstawiono opis projektu pod kryptonimem „Monitoring” w zakresie systemu łączności. W ramach tego systemu przedstawiono zestawienie możliwych do wykorzystania protokołów transmisji dla: IP, UDP i TCP. Ponadto zaprezentowano wyniki analiz środków łączności, z których najbardziej obiecujące dotyczą transmisji bezprzewodowej: Wi-Fi oraz CDMA/3G/ LTE. Analiza architektury omawianego systemu wykazała również konieczność 
wprowadzenia środków bezpieczeństwa: mechanizmów sprzętowych - ściany ogniowej, czy IDS/IPS. Ponadto zdefiniowano konieczność zastosowania mechanizmów uwierzytelniania użytkowników w systemie, w celu ich późniejszej identyfikacji w zakresie wykonanych prac.

\section{Wnioski}

Przygotowywany demonstrator systemu monitorowania nie musi być w pełni zabezpieczonym systemem, ponieważ nie jest rozwiązaniem docelowym. Wprowadzenie na tym etapie możliwie wysokiego poziomu bezpieczeństwa wymagałoby zwiększenia nakładu pracy oraz zastosowania dodatkowych urządzeń, co powoduje istotny wzrost kosztów. Oczywiste jest, że finalnie system musi mieć zaimplementowane niezbędne mechanizmy bezpieczeństwa. Oznacza to, że jego architektura winna przewidywać ich wprowadzenie.

\section{WYKAZ SKRÓTÓW}

CDMA - Code Division Multiple Access

CNBOP-PIB - Centrum Naukowo-Badawcze Ochrony Przeciwpożarowej Państwowy Instytut Badawczy

IDS/IPS - Intrusion Detection System/Intrusion Prevention System

IEG - Information Exchange Gateway

IP - Internet Protocol

LTE - Long Term Evolution

NCBR - Narodowe Centrum Badań i Rozwoju

PKI - Public Key Infrastructure

RAM - Random Access Memory

TCP - Transmission Control Protocol

UDP - User Datagram Protocol

WWW - World Wide Web 



\title{
SIEĆ SENSOROWA SYSTEMU POMIARU I DIAGNOZOWANIA POMP STOSOWANYCH W JEDNOSTKACH RATOWNICZO-GAŚNICZYCH
}

\author{
Mikołaj Sobczak \\ Michał Pasieka \\ Bartosz Kukawka
}

\section{Wprowadzenie}

Celem opracowania jest prezentacja części tworzonego projektu demonstratora systemu umożliwiającego stały nadzór eksploatacyjny wybranego wyposażenia straży pożarnej w zakresie niezawodności i skuteczności działania.

Opracowanie metodologii stałego nadzoru eksploatacji wybranych obszarów wyposażenia straży pożarnej w zakresie niezawodności i skuteczności działania jest realizowane w ramach projektu rozwojowego $\mathrm{nr}$ DOBR-BIO4/051/13087/2013. Na podstawie wymagań dotyczących metodologii diagnostyki wybranego sprzętu straży pożarnej, wykonanej w ramach projektu przez konsorcjum, został opracowany system spełniający wymagane parametry i funkcje. Wszystkie rozwiązania zostały zaprojektowane i wybrane przez specjalistów praktyków, tak aby uzyskać nowoczesny i trwały system umożliwiający dalszy rozwój.

Technologią, która została opracowana, jest modułowy bezprzewodowy system monitoringu sprzętu straży pożarnej dedykowany dla autopomp, motopomp, pomp sprzętu hydraulicznego. W opracowaniu przedstawiono dotychczasowe prace nad projektem. Opisane zostały elementy składowe systemu i oprogramowania, a w szczególności projektowane elementy stanowiące część sprzętową. Określona została architektura systemu oraz konkretne rozwiązania sprzętowe, realizujące wymagane zadania takie jak: dokonywanie pomiarów z czujników zainstalowanych na pompie, akwizycja i interpretacja zebranych danych, sygnalizacja stanu pracy, przekazywanie informacji o pracy urządzenia do pozostałych elementów systemu oraz dostarczanie i zrządzanie energią dla poszczególnych modułów systemu.

Awarie sprzętu pożarniczego podczas pracy mogą spowodować dezorganizację akcji lub jej niepowodzenie. Łatwo wyobrazić sobie skutki unieruchomienia pompy podczas akcji gaśniczej. Cenną informacją $\mathrm{w}$ takim wypadku byłaby wiadomość z systemu diagnostycznego o nadchodzącej awarii lub nieprawidłowej pracy, która może doprowadzić do awarii. Jednym z przykładów może być nieprawidłowa praca z powodu przytkania smoka węża ssawnego. Projektowany system monitoringu pomp będzie mógł poinformować dowódcę akcji o problemie, aby mógł podjąć 
stosowne kroki. Również analiza okresowa badanych parametrów i ich charakterystyk pozwoli uzyskać informowację o nieprawidłowej pracy i potrzebie wcześniejszego wycofania sprzętu ze służby i przekazania go na serwis.

Architektura systemu została przedstawiona na ryc. 1. Składa się ona z następujących elementów:

- czujników pomiarowych - są to narzędzia służące do przetwarzania sygnału pomiarowego, tj. sygnału zawierającego informacje o wartościach wielkości fizycznych (np. temperatura, przepływ, drgania itp.), na inne wielkości fizyczne, w szczególności na napięcie lub natężenie prądu, w przypadku czujników analogowych, lub na sygnał cyfrowy w przypadku czujników cyfrowych,

- modułu pomiarowego - odpowiadającego za zbieranie danych z przetworników, ich obróbkę i przesyłanie do jednostki akwizycji danych,

- modułu komunikacyjnego - zapewniającego łączność pomiędzy wszystkimi elementami systemu,

- jednostki akwizycji danych - odpowiadającej za zbieranie danych z modułów pomiarowych, ich obróbkę i przesyłanie do kolejnych węzłów systemu,

- serwera lokalnego - odpowiadającego za zbieranie danych z wielu jednostek akwizycji danych i ich przesyłanie do serwera głównego. Umożliwia też monitorowanie urządzeń znajdujących się w zasięgu z poziomu konsoli mobilnej,

- serwera głównego - platformy serwerowej, odpowiedzialnej za przetwarzanie, archiwizowanie, analizę i udostępnianie danych gromadzonych przez system,

- konsoli mobilnej - pozwalającej na monitorowanie urządzeń bezpośrednio biorących udział w akcji,

- konsoli operatora - pozwalającej na uzyskanie dostępu do wszystkich danych gromadzonych w systemie.

\section{Projekt elementów składowych węzła monitorującego}

Węzeł monitorujący to zestaw elementów i urządzeń zainstalowanych na pompie umożliwiający podłączenie jej do systemu i zdalny nadzór jej pracy.

W celu identyfikacji i zdiagnozowania nieprawidłowej pracy monitorowanego urządzenia wymagana jest instalacja czujników umożliwiających pomiary odpowiednich wielkości fizycznych. Podstawowymi wartościami fizycznymi, które będą mierzone, jest temperatura oraz ciśnienie w różnych zakresach oraz punktach pomiarowych.

Projektowany system jest przeznaczony dla różnego rodzaju pomp, przez co wymagana jest elastyczność i modułowość węzła monitorującego. Będzie się on składać z kilku elementów:

- czujników,

- modułu pomiarowego,

- jednostki akwizycji danych,

- modułu komunikacyjnego. 


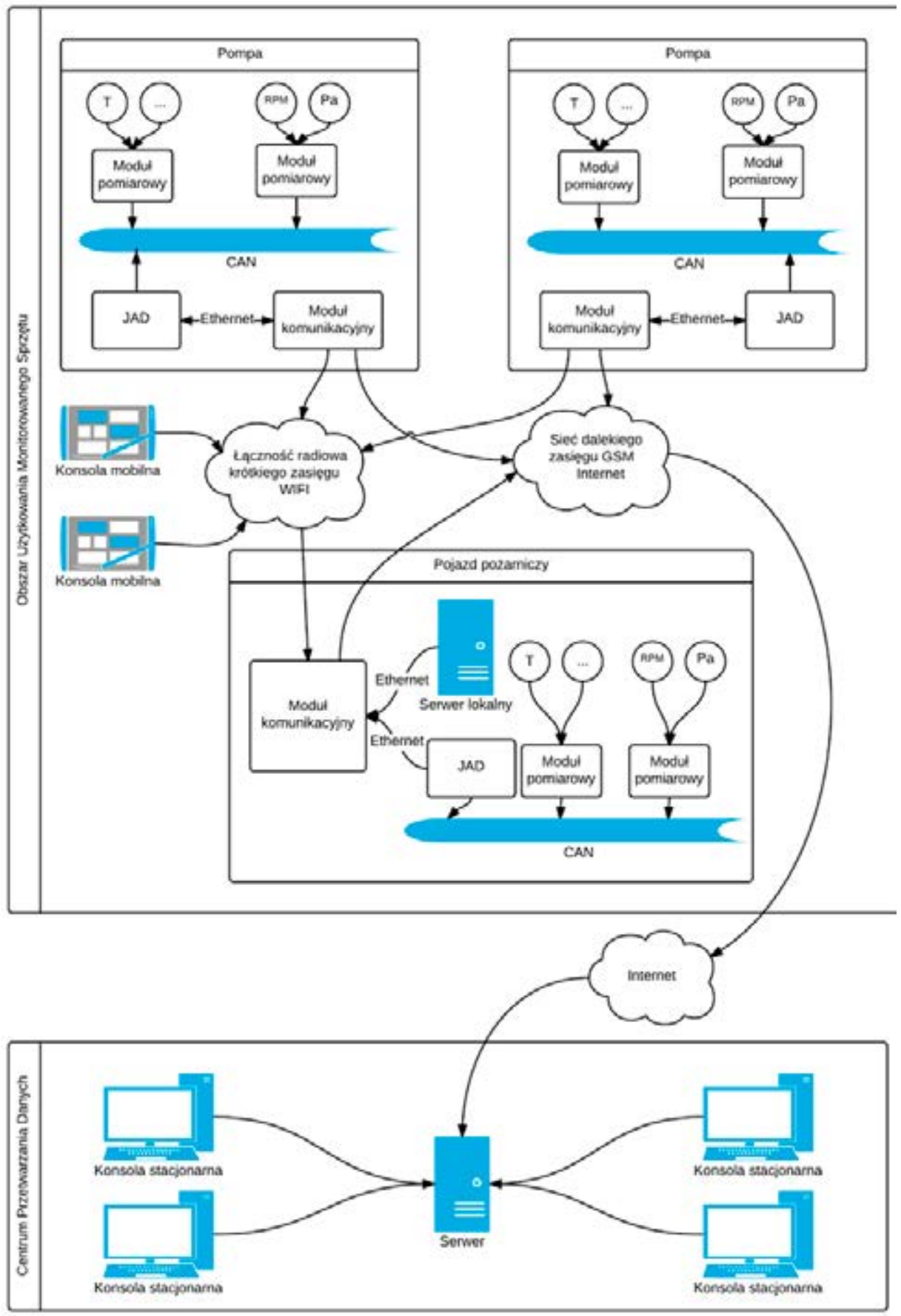

Ryc. 1. Architektura systemu

Źródło: Opracowanie własne. 


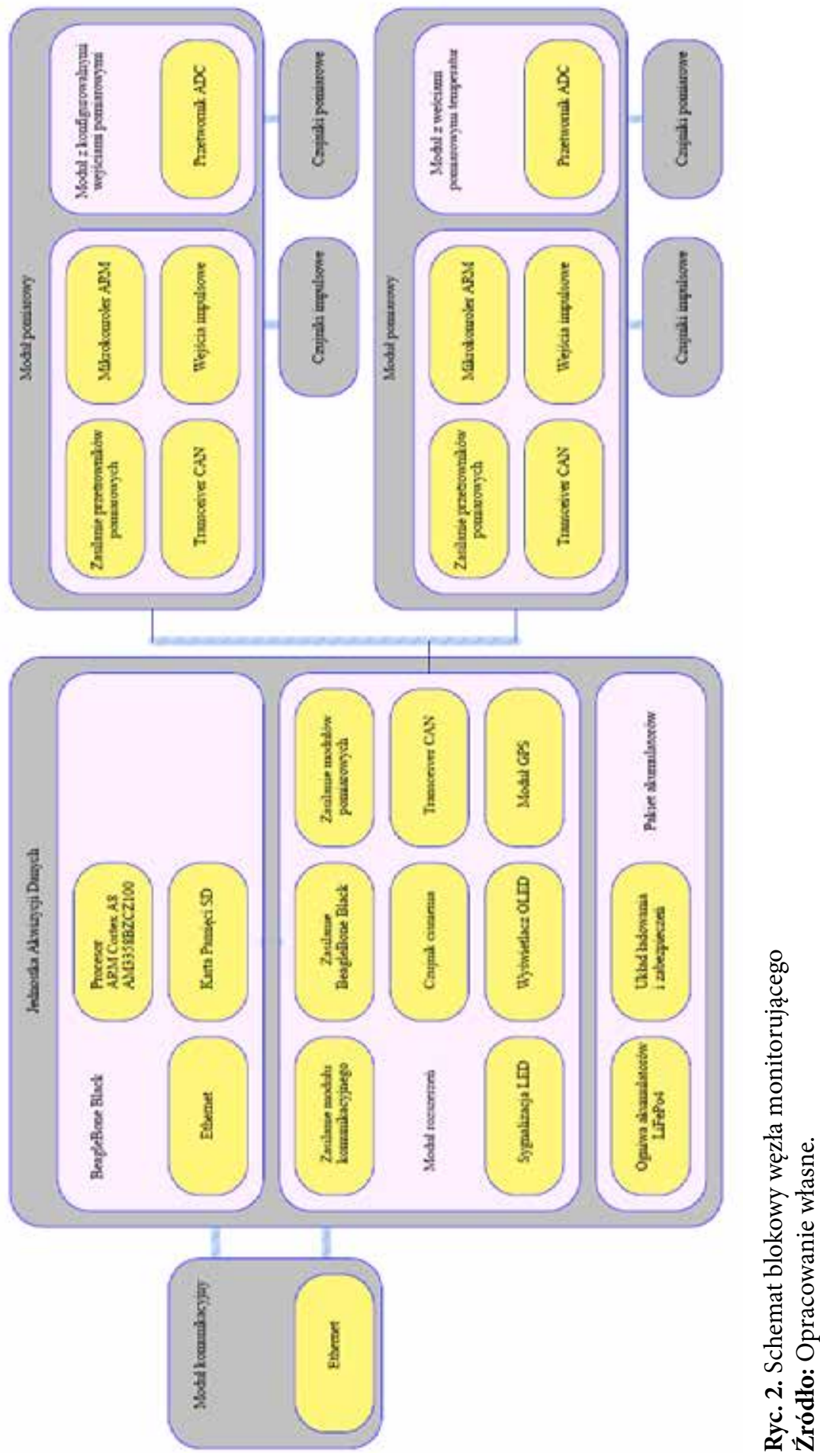


Niezbędnymi elementami węzła monitorującego są jednostka akwizycji danych i moduł komunikacyjny. W zależności od typu i liczby zamontowanych czujników pomiarowych na pompie możliwa będzie konfiguracja odpowiedniej liczby modułów pomiarowych. W celu uzyskania wysokiej niezawodności wykorzystane będą czujniki przemysłowe posiadające ustandaryzowane interfejsy wyjściowe. Powstaną dwa typy modułów pomiarowych, dedykowany do pomiaru temperatur oraz drugi z konfigurowalnymi interfejsami przemysłowymi. Poprzez sieć CAN moduły pomiarowe będą przesyłać dane do jednostki akwizycji danych. Po przetworzeniu wyników pomiarów informacja o statusie urządzenia będzie przekazana poprzez sieć Ethernet do modułu komunikacyjnego. Jednostka akwizycji danych będzie zasilać wszystkie moduły węzła monitorującego $\mathrm{z}$ wewnętrznych akumulatorów.

\section{Jednostka akwizycji danych}

Jako jednostka obliczeniowa zapewniająca wymagane parametry został wybrany mikroprocesor ARM Cortex A8 AM3358BZCZ100 firmy Texas Instruments. Układ ten jest zamontowany w płytce rozwojowej BeagleBone Black będącej projektem z otwartą i ogólnie dostępną dokumentacją techniczną rozwijaną przez fundację Beaglebone.org.

W tabeli 1 wymienione zostały główne parametry modułu.

TABela 1

Parametry BeagleBone Black rev. C

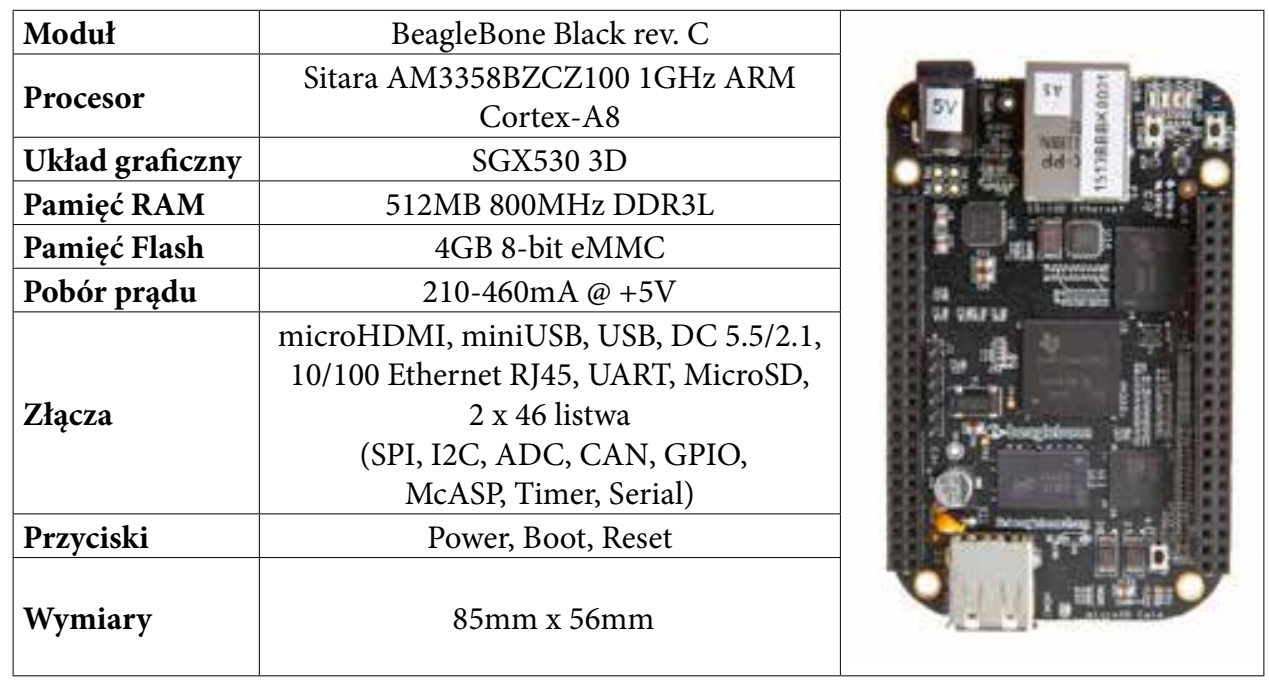

Źródło: BeagleBoard.org Foundation, Beagleboard: BeagleBoneBlack, http://elinux.org/ Beagleboard:BeagleBoneBlack [Dostęp: 16.02.2015.]. 
Do złącz listwowych zostanie przyłączony moduł rozszerzeń z niezbędnymi peryferiami. Będą na nim umieszczone przetwornice zasilające DC/DC dla: modułów pomiarowych, modułu komunikacyjnego oraz samego modułu BeagleBone. Ponadto wyposażona będzie ona $\mathrm{w}$ transceiver CAN do komunikacji z modułami pomiarowymi oraz złącze $\mathrm{z}$ interfejsem MBus, przez które odczytywany będzie stan pakietu akumulatorów. Podstawowa wizualizacja stanu pracy przedstawiana będzie za pomocą diod LED, natomiast bardziej szczegółowe informacje zostaną wyświetlone na wyświetlaczu graficznym OLED. Na module rozszerzeń znajdzie się również moduł GPS wraz ze złączem na antenę. Dzięki temu możliwa będzie precyzyjna lokalizacja danej pompy na mapie.

Zasilanie dostarczane będzie z pakietu akumulatorów typu LiFePo4. Przykładowy wynik testu akumulatora przedstawia ryc. 3. Jest to aktualna procentowa pojemność w stosunku do wykonanych cykli ładowania. Po 20000 pełnych cykli ładowania i rozładowania akumulatora mają one nadal $65 \%$ początkowej pojemności. Ilość tę można porównać do 55 lat eksploatacji przy ładowaniu raz dziennie. Są to ogniwa stabilne chemicznie, przez to bardziej bezpieczne w porównaniu z litowo-polimerowymi. Dzięki większej żywotności są tańsze w późniejszym etapie eksploatacji systemu.

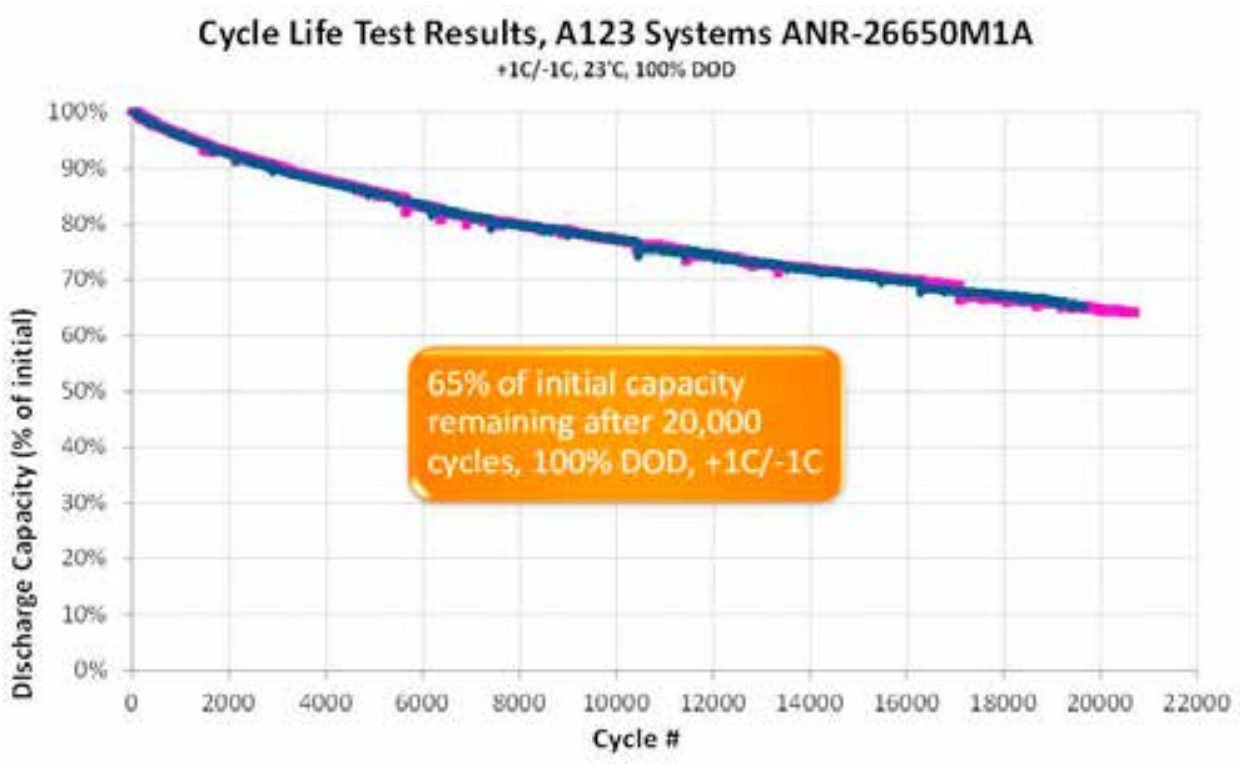

Ryc. 3. Wynik testu żywotności ogniwa firmy A123 systems

Źródło: Analog Devices. CN0287: Isolated 4-Channel, Thermocouple/RTD Temperature Measurement System with $0.5^{\circ} \mathrm{C}$ Accuracy, http://www.analog.com/en/design-center/ reference-designs/hardware-reference-design/circuits-from-the-lab/CN0287.html. [Dostęp: 16.02.2015]. 
Na ryc. 4. przedstawiono schemat blokowy pakietu akumulatorów. Ogniwa akumulatorów będą zintegrowane z modułem elektronicznym zapewniającym wszystkie podstawowe zabezpieczenia i funkcje takie jak: nadzorowanie procesu ładowania, balansowanie napięcia poszczególnych ogniw, pomiar zgromadzonej i zużytej energii w pakiecie, dzięki czemu znana będzie dokładna wartość poziomu naładowania. Wbudowana sygnalizacja LED umożliwi sprawdzenie stanu naładowania zdemontowanych zapasowych pakietów. Podstawowymi zabezpieczeniami są: zabezpieczenie przed zbyt niskim lub wysokim napięciem ogniw, przeciążeniem lub przegrzaniem pakietu przy ładowaniu lub rozładowywaniu, zabezpieczenie przed zwarciem. Ponadto układ będzie posiadać szereg dodatkowych zabezpieczeń mogących całkowicie rozłączyć pakiet w przypadku nieodwracalnych uszkodzeń.

Do wejścia zasilania pakietu podłączony będzie alternator pompy, jeśli będzie ona w niego wyposażona, lub zewnętrzne źródło zasilania do ładowania pakietu takie jak instalacja $\mathrm{w}$ wozie przewożącym pompę lub zasilacz $\mathrm{w}$ jednostce straży pożarnej. Wyjście pakietu zasilać będzie moduł rozszerzeń jednostki akwizycji danych dystrybuujący dalej energię do pozostałych modułów.

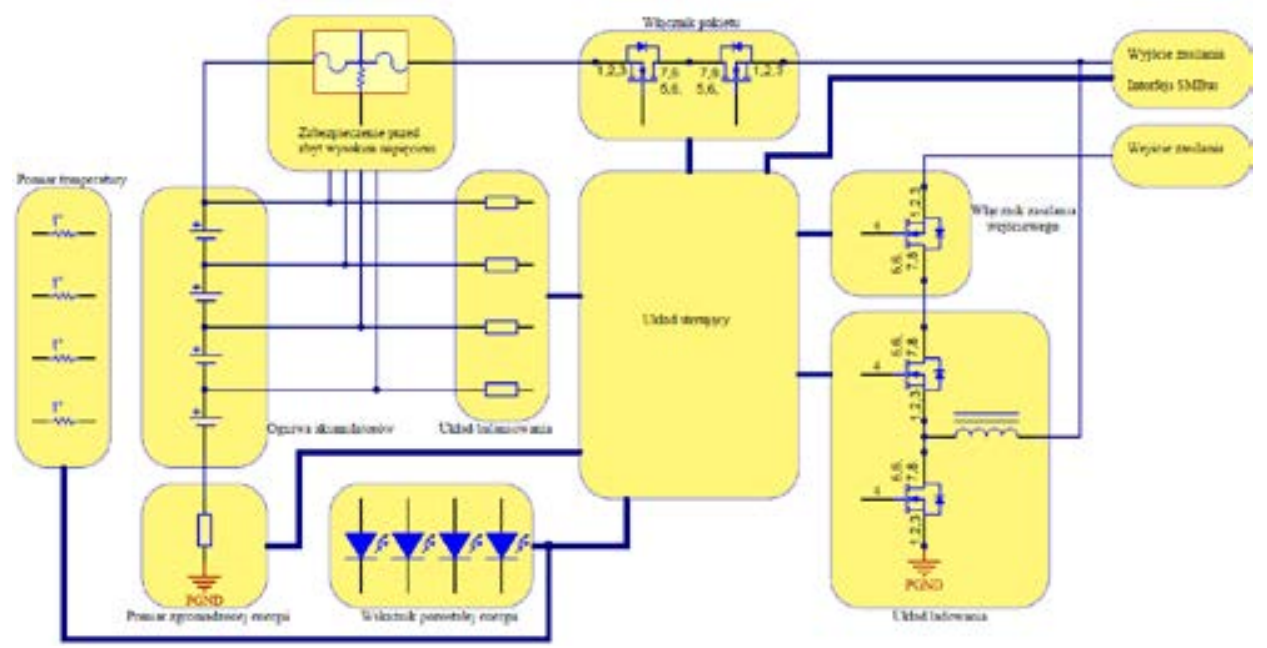

Ryc. 4. Schemat blokowy pakietu akumulatorów

Źródło: Opracowanie własne.

\section{Moduł pomiarowy}

Moduł pomiarowy będzie odczytywał dane z czujników i wysyłał wynik poprzez sieć CAN. Będzie się on składać z dwóch układów, pierwszy zawierać będzie: wejścia impulsowe umożliwiające podłączenie przepływomierzy impulsowych, układ zasilający, mikrokontroler ARM oraz transceiver CAN zapewniający łączność. Drugi układ 
będzie dostępny w dwóch wariantach: do pomiaru temperatur oraz uniwersalnym do pomiaru sygnałów z czujników przemysłowych. W obu wypadkach do pomiaru wartości analogowych zostanie wykorzystany przetwornik 24-bitowy typu sigma delta dokonujący maksymalnie 4800 pomiarów na sekundę.

Moduł wejściowy do pomiaru temperatur posiadać będzie porty wejściowe umożliwiające podłączenie czterech czujników temperatury takich jak termopary wymagające kompensacji zimnego złącza lub termometr rezystancyjny (RTD) z połączeniem dwu-, trzy- lub czteroprzewodowym. Programowa regulacja źródła prądowego zasilającego czujniki RTD umożliwi odpowiednie dostosowanie szumu w stosunku do liniowości pomiaru. Zgodnie z dokumentacją techniczną producenta $\mathrm{CN} 0287^{1}$ dokładność pomiaru temperatury za pomocą termopary wynosić będzie maksymalnie $0,8^{\circ} \mathrm{C}$, co jest uzależnione od dokładności pomiaru temperatury zimnego złącza. Dla pomiaru z wykorzystaniem czujnika RTD PT100 dokładność wynosi $0,1^{\circ} \mathrm{C}$.

Uniwersalny moduł wejściowy oparty na dokumentacji producenta $\mathrm{CN} 0209^{2}$ posiadać będzie dwa wejścia do pomiaru prądu w zakresie $4 \mathrm{~mA}$ do $20 \mathrm{~mA}$ oraz dwa wejścia konfigurowalne umożliwiające pomiary: napięcia w zakresie $\pm 10 \mathrm{~V}$, pomiar temperatury z wykorzystaniem termopary lub termometru rezystancyjnego RTD dwu-, trzy- lub czteroprzewodowego. W tabeli 2 przedstawione zostały wyniki pomiarów efektywnej rozdzielczości i szumu w zależności od zastosowanej konfiguracji przetwornika analogowo-cyfrowego. Wyniki opierają się na próbie 1000 pomiarów.

TABELA 2

Możliwości pomiarowe modułu wejściowego CN0209

\begin{tabular}{|c|c|c|c|}
\hline Wejście & Konfiguracja AD7193 & Szum RMS [nV] & $\begin{array}{c}\text { Efektywna } \\
\text { rozdzielczość } \\
\text { [bity] }\end{array}$ \\
\hline $\begin{array}{c}\text { Napięcie } \\
\pm 10 \mathrm{~V}\end{array}$ & $\begin{array}{c}\text { Wzmocnienie 1, filtr } 50 \mathrm{~Hz}, \\
\text { Dane wyjściowe } 50 \mathrm{~Hz}\end{array}$ & 7940 & 19.15 \\
\hline $\begin{array}{c}\text { Prąd } 4 \mathrm{~mA} \text { do } \\
20 \mathrm{~mA}\end{array}$ & $\begin{array}{c}\text { Wzmocnienie 1, filtr } 50 \mathrm{~Hz}, \\
\text { Dane wyjściowe } 2.63 \mathrm{~Hz}\end{array}$ & 931 & 22.24 \\
\hline RTD & $\begin{array}{c}\text { Wzmocnienie 16, filtr } 50 \mathrm{~Hz}, \\
\text { Dane wyjściowe } 2.63 \mathrm{~Hz}\end{array}$ & 243 & 20.29 \\
\hline Termopara & $\begin{array}{c}\text { Wzmocnienie } 128, \text { filtr } 50 \mathrm{~Hz}, \\
\text { Dane wyjściowe } 2.63 \mathrm{~Hz}\end{array}$ & 220 & 19.23 \\
\hline
\end{tabular}

Źródło: CN0209: Fully Programmable Universal Analog Front End for Process Control Applications, http://www.analog.com/en/design-center/reference-designs/hardware-reference-design/circuits-from-the-lab/CN0209.htm [Dostęp: 16.02.2015].

1 Analog Devices. CN0287: Isolated 4-Channel, Thermocouple/RTD Temperature Measurement System with $0.5^{\circ} \mathrm{C}$ Accuracy, http://www.analog.com/en/design-center/reference-designs/hardware-reference-design/circuits-from-the-lab/CN0287.html. [Dostęp: 16.02.2015].

2 CN0209: Fully Programmable Universal Analog Front End for Process Control Applications, http://www.analog.com/en/design-center/reference-designs/hardware-reference-design/circuits-fromthe-lab/CN0209.htm. [Dostęp: 16.02.2015.]. 


\section{Moduł komunikacyjny}

Moduł komunikacyjny umożliwi przekazywanie informacji do serwera i konsol operatorskich. Przewidywana jest łączność bliskiego zasięgu za pomocą sieci Wi-Fi oraz dalekiego zasięgu przy wykorzystaniu infrastruktury sieci GSM. Szczegółowy projekt modułu komunikacyjnego zostanie opracowany przez partnera projektu. Najważniejsze informacje o statusie pracy danej pompy będą przekazywane na bieżąco poprzez sieć GSM do serwera, a następnie do wszystkich zainteresowanych daną akcją. Szczegółowe informacje na temat pracy urządzenia będą logowane w jednostce akwizycji danych. Dostęp do nich możliwy będzie poprzez sieć Wi-Fi. Zapis pracy danego urządzenia będzie automatycznie przesyłany do serwera, poprzez sieć Wi-Fi, po powrocie do jednostki ratowniczo-gaśniczej. Jednostka akwizycji danych będzie zasilać moduł komunikacyjny oraz przesyłać dane za pośrednictwem interfejsu Ethernet.

\section{Wnioski}

Powyższe opracowanie przedstawia podstawowe informacje dotyczące działania i budowy węzła monitorującego. Dzięki modułowej architekturze wykorzystującej magistralę danych CAN możliwa będzie rozbudowa o kolejne moduły pomiarowe obsługujące dodatkowe czujniki. Zastosowanie innego rodzaju czujników z nietypowymi interfejsami wymagać będzie zaprojektowania nowych obwodów wejściowych modułu pomiarowego wraz z oprogramowaniem bez konieczności ingerencji $\mathrm{w}$ pozostałe moduły systemu pomiarowego. 



\title{
BADANIE WPEYWU WYBRANYCH USZKODZEŃ NA PARAMETRY PRACY MOTOPOMPY POŻARNICZEJ -WYZNACZENIE WARTOŚCI PARAMETRÓW DLA STANU ZDATNOŚCI
}

\author{
Włodzimierz Kupicz \\ Paweł Ogrodnik
}

\section{Wstęp}

Silniki spalinowe napędzające motopompy i inny sprzęt pożarniczy pracują zazwyczaj przy stałych prędkościach obrotowych. Do ich diagnozowania mogą zostać użyte następujące parametry diagnostyczne:

- moment obrotowy,

- godzinowe zużycie paliwa,

- temperatura spalin.

Odśrodkowa pompa pożarnicza pracuje w stałych lub wolnozmiennych warunkach. Parametrami diagnostycznymi mogą być tutaj:

- ciśnienie tłoczenia,

- podciśnienie ssania,

- intensywność przepływu wody,

- temperatura wody w kolektorze ssącym i tłocznym,

- parametry akustyczne takie jak widmo natężenia dźwięku.

Podstawą budowy metody diagnostycznej jest wybór parametrów diagnostycznych, ustalenie granicznych wartości parametrów dla stanu zdatnego oraz dla poszczególnych uszkodzeń, opracowanie algorytmów diagnozowania ${ }^{1}$. Liczbę stanów silnika spalinowego i wirowej odśrodkowej pompy ustalono, przyjmując następujące założenia:

1) dwuwartościowa ocena stanów. Zbiór stanów motopompy określony jest przez wyrażenie:

$$
W=\left\{w^{1}, w^{0}\right\}
$$

1 W. Kupicz, P. Ogrodnik, Moment obrotowy, godzinowe zużcie paliwa, oraz temperatura spalin jako parametry diagnostyczne silnika spalinowego o zapłonie samoczynnym pracujacego w warunkach stacjonarnych, „Zeszyty naukowe SGSP”, 44 (2012), 55-66; W. Kupicz, P. Ogrodnik, Problemy eksploatacji pojazdów i sprzętu ratowniczo-gaśniczego w Państwowej Straży Pożarnej, „Logistyka”, 6 (2014). 
gdzie:

$w^{1}-$ klasa stanów zdatności;

$w^{0}$ - klasa stanów niezdatności.

2) szeregowa struktura niezawodnościowa obiektu badań;

3) w silniku o p elementach występuje pojedyncze uszkodzenie, zatem mamy:

- jeden stan zdatności w ${ }^{1}$,

- $w^{0}=\mathrm{p}-$ stanów niezdatności.

4) stan zdatności zdefiniowano następująco:

$$
\bigwedge_{y_{n} \in Y_{n z}}\left(y_{n \max }<y_{n}<y_{n \min }\right) \Rightarrow w_{i} \in w^{1}
$$

gdzie:

$\mathrm{y}_{\mathrm{n}}$ - wartości parametru diagnostycznego;

$\mathrm{y}_{\mathrm{nmin}}, \mathrm{y}_{\mathrm{nmax}}$ - wartości graniczne parametru diagnostycznego;

$\mathrm{Y}_{\mathrm{nz}}$ - zbiór niezależnych i zupełnych parametrów diagnostycznych.

5) stan niezdatności zdefiniowano następująco:

$$
\underset{\substack{y_{n} \in Y_{n z} \\ n=1, N}}{\vee}\left(y_{n}>y_{n \max } \cup y_{n}<y_{n \min }\right) \Rightarrow w_{i} \in w^{0}
$$

Podstawą metodyki badań było ustalenie wzorcowych wartości parametrów diagnostycznych dla stanu zdatności silnika oraz wirowej pompy odśrodkowej. Wykonane zostały kompleksowe badania charakterystyk sygnałów diagnostycznych w funkcji wielu zmiennych. Zasymulowane zostały wybrane uszkodzenia i przeprowadzono badania wpływu uszkodzeń na wartości parametrów diagnostycznych. Analiza wyników badań pozwoli na opracowanie algorytmów diagnozowania do zastosowania w systemie monitorowania wybranego sprzętu ratowniczo-gaśniczego. W efekcie opracowane zostaną wytyczne do doboru czujników przemysłowych pracujących w sposób ciągły w systemie monitorowania wybranego sprzętu ratowniczo-gaśniczego.

\section{Stanowisko oraz obiekt przeprowadzonych badań}

\section{Stanowisko do wykonania badań}

Stanowisko pomiarowe do badania i diagnozowania motopompy pożarniczej zostało zbudowane specjalnie w celu przeprowadzenia badań doświadczalnych. Ogólnie w skład stanowiska wchodzi część pomiarowa oraz instalacja wodna umożliwiająca badanie motopompy pracującej w obiegu zamkniętym. Zbiornik zapasu wody o pojemności $\mathrm{V}=4,5 \mathrm{~m}^{3}$ i średnicy $2300 \mathrm{~mm}$ został zaprojektowany i wykonany z blach stalowych ocynkowanych, ze stali S350GD. Dodatkowo wykonano podest dla motopompy $1000 \times 1200 \mathrm{~mm}$, umożliwiający pracę pompy ze 
ssaniem z geometrycznej wysokości 1,5 m. Układ rejestracji sygnałów został wyposażony w dwa rejestratory sygnałów wolno- i szybkozmiennych. Specjalnie do celów projektowych zostało opracowane oprogramowanie pomiarowo-rejestrujące Motopompa.exe pozwalające na monitoring mierzonych parametrów. Integralną częścią stanowiska badawczego jest miernik poziomu dźwięku SVAN 979 firmy SVANTEK. Urządzenie to należy do grupy cyfrowych mierników dźwięku i drgań, klasy 1 (SLM i VLM) oraz analizator 1/1, 1/3, 1/6 lub 1/12 oktawy pracujący w czasie rzeczywistym. Przyrząd zaprojektowano dla ogólnych pomiarów dźwięku i drgań, monitorowania środowiska. Schemat stanowiska został przedstawiony na ryc. 1 .

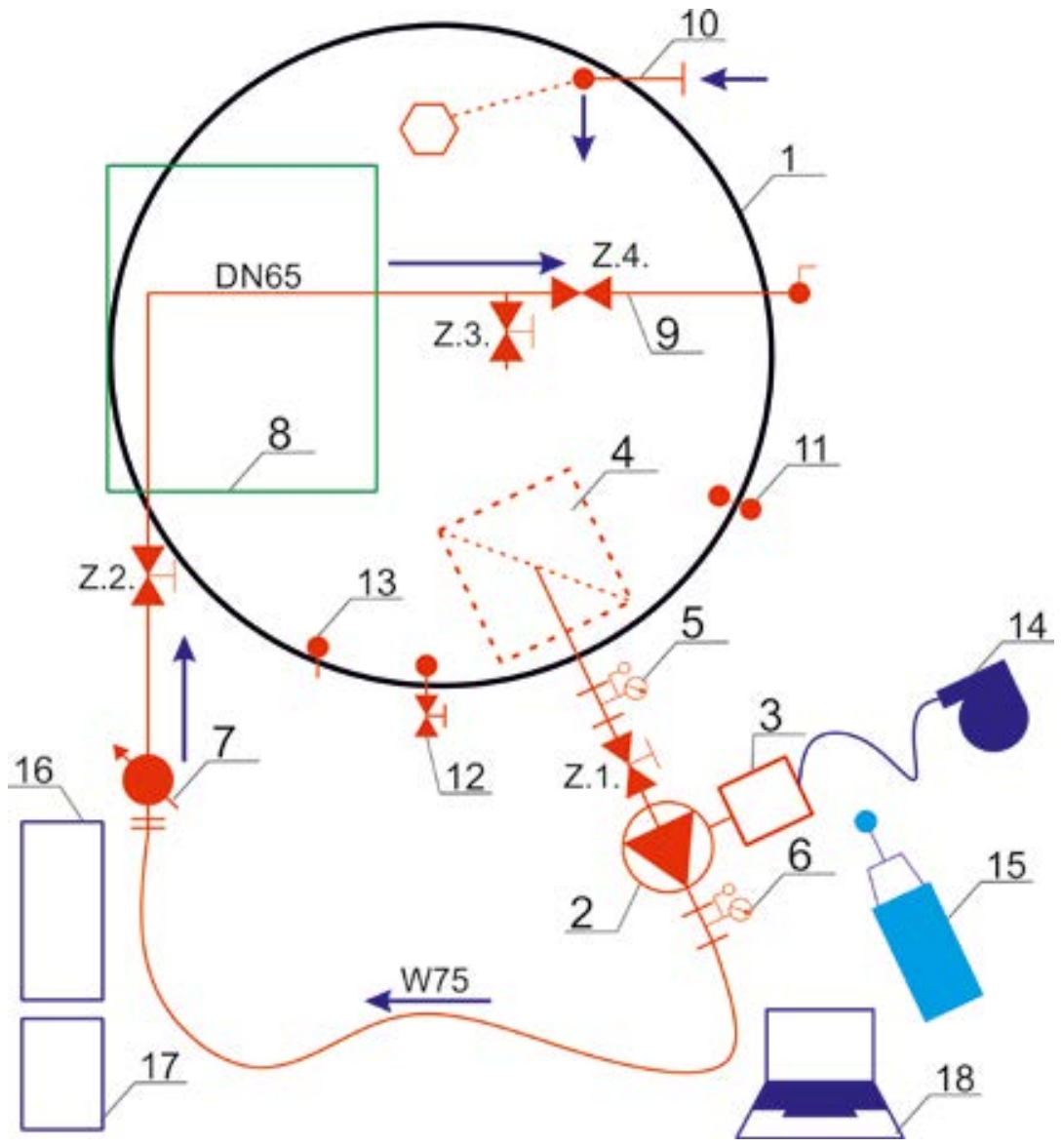

Ryc. 1. Schemat stanowiska do wykonania badań

Źródło: Opracowanie własne.

gdzie:

1. Zbiornik wody o pojemności $4,5 \mathrm{~m}^{3}$,

2. Motopompa Otter 6/5,

3. Silnik motopompy, 
4. Rurociąg ssawny z płytą antywirową,

5. Układ pomiaru podciśnienia na ssaniu pompy (manowakuometr i przetwornik ciśnienia),

6. Układ pomiaru ciśnienia na tłoczeniu pompy (manometr i przetwornik ciśnienia),

7. Przepływomierz elektromagnetyczny FLOWNET DN65,

8. Podest roboczy z wciągarką przewidziany do pracy pompy ze ssaniem $1,5 \mathrm{~m}$,

9. Rurociąg testowy DN 65,

10. Zawór pływakowy do samoczynnego napełniania zbiornika,

11. Przelew,

12. Zawór odwadniający zbiornik,

13. Czujnik temperatury wody w zbiorniku,

14. Wyciąg spalin,

15. Miernik poziomu dźwięku SVAN 979 firmy SVANTEK,

16. Szafka pomiarowa SzP-1,

17. Czujnik ciśnienia atmosferycznego i temperatury otoczenia,

18. Rejestrator komputer pomiarowy PC z oprogramowaniem Motopompa.exe.

\section{Obiekt badań}

Obiektem badań jest motopompa pożarnicza OTTER 6/5 będąca na wyposażeniu Pracowni Sprzętu Ratowniczo-Gaśniczego SGSP. Pompa została wyposażona w silnik spalinowy chłodzony powietrzem, dwucylindrowy, czterosuwowy silnik Briggs\&Stratton o mocy 18 KM. Całkowita masa suchej motopompy wynosi $58 \mathrm{~kg}$, natomiast maksymalna wysokość ssania 7,5 $\mathrm{m}$. Wydajność pompy przy wysokości ssania $3 \mathrm{~m}$ :

- $5001 /$ min przy 6 bar,

- $800 \mathrm{l} / \mathrm{min}$ przy 5 bar,

- $1000 \mathrm{l} / \mathrm{min}$ przy 4 bar.

Zasada działania wirowej pompy odśrodkowej polega na ruchu wirnika obracającego się w pompie wypełnionej cieczą. Siła odśrodkowa wywołuje przepływ cieczy przez kanały wirnika od środka ku obwodowi. Na wewnętrznym obwodzie koła wirnika powstaje podciśnienie. Ciśnienie atmosferyczne działające na zwierciadło wody w zbiorniku wprawia $\mathrm{w}$ ruch ciecz znajdującą się w przewodzie ssawnym, która następnie wpływa do wirnika z określoną prędkością i ciśnieniem ${ }^{2}$. Na ryc. 2 przedstawiony został obiekt badań.

2 S. Łazarkiewicz., A.T. Troskolański, Pompy wirowe, PWT, Warszawa 1959. 


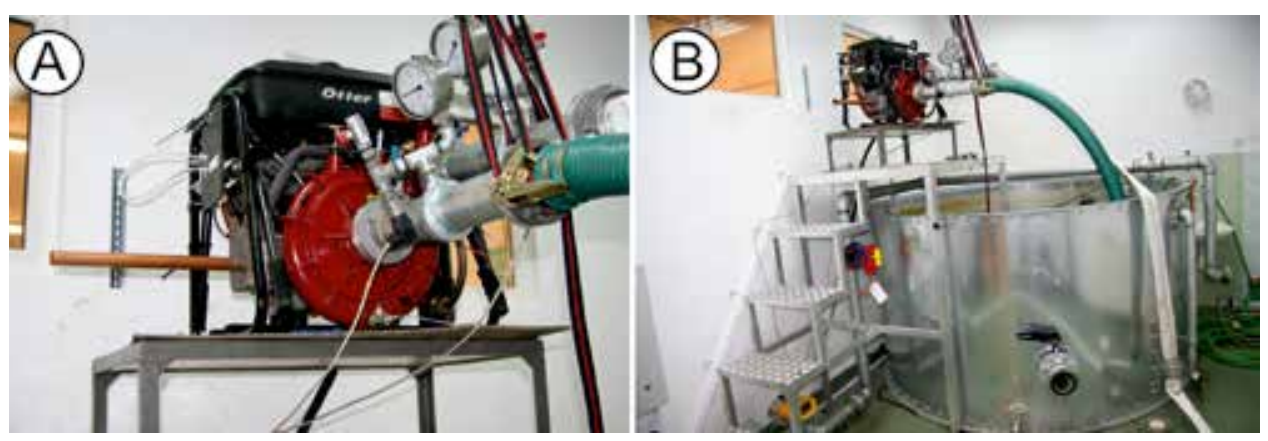

Ryc. 2. Obiekt badań - motopompa pożarnicza OTTER 6/5

Źródło: Opracowanie własne.

\section{Metodyka wykonania badań}

Badania zostały podzielone na dwie części: badania wstępne oraz badania zasadnicze. Celem badań wstępnych było:

- określenie własności wytypowanych sygnałów pomiarowych - powtarzalności, stacjonarności;

- wytypowanie i weryfikacja parametrów diagnostycznych na podstawie zmierzonych wielkości fizycznych;

- określenie wpływu warunków środowiskowych na mierzone wartości parametrów diagnostycznych takich jak: temperatura otoczenia, ciśnienie atmosferyczne, stan cieplny silnika spalinowego oraz temperatura pompowanej wody;

- określenie wzorcowych wartości parametrów diagnostycznych odpowiadających stanowi zdatności motopompy pożarniczej;

- określenie wielowymiarowych równań regresji uwzględniających wpływ warunków środowiskowych na wartości parametrów diagnostycznych - równań korekcyjnych;

- oszacowanie całkowitej niepewności wyznaczenia poszczególnych parametrów diagnostycznych uwzględniających rozrzut wyników badań, dokładność aparatury pomiarowej oraz wpływ innych czynników.

Celem badań zasadniczych jest:

- wyznaczenie macierzy parametrów diagnostycznych dla stanu zdatnego;

- zasymulowanie uszkodzeń i nieprawidłowości pracy silnika spalinowego oraz wirowej odśrodkowej pompy;

- wykonanie serii pomiarów w niezbędnej liczbie przy określonych stanach niezdatności; 
- określenie wpływu poszczególnych niezdatności na wartości wytypowanych parametrów diagnostycznych;

- określenie algorytmów diagnozowania - identyfikacji stanu oraz lokalizacji uszkodzeń;

- na podstawie uzyskanych wyników weryfikacja przydatności poszczególnych parametrów i redukcja macierzy - usunięcie parametrów, których nośność informacyjna o stanie obiektu jest niezadowalająca.

\section{Wyniki badań}

W pierwszym etapie badań wyznaczono charakterystyki parametrów diagnostycznych pompy dla stanu zdatnego i w warunkach atmosferycznych zbliżonych do normalnych. W czasie badań temperatura otoczenia i wody w zbiorniku wynosiła około $20^{\circ} \mathrm{C}$, a ciśnienie atmosferyczne około $1000 \mathrm{hPa}$. Badania prowadzono $\mathrm{w}$ różnych warunkach pracy. W pierwszym etapie dla wyznaczenia powtarzalności sygnałów przeprowadzono 85 pomiarów w 8 seriach, przy parametrach odpowiadających nominalnym warunkom pracy pompy (6 bar, 500 l/min). Ze względu na ograniczenia stanowiska badawczego wysokość ssania wynosiła 1,5 m.

W tabeli 1 przedstawiono wyniki badań w postaci średnich wartości parametru diagnostycznego oraz odchylenia standardowego wartości średniej, które przyjęto za miarę rozrzutu wyników.

TABELA 1

Statystyki opisowe wyników badań diagnostycznych

\begin{tabular}{|l|r|r|r|r|r|r|r|r|r|r|}
\hline & & & & &
\end{tabular}

Źródło: Opracowanie własne. 
Warunki atmosferyczne podczas prowadzenie badań powtarzalności w punkcie nominalnym pompy przedstawiono w tabeli 2 .

TABELA 2

Warunki atmosferyczne podczas prowadzenia badań

\begin{tabular}{|l|c|c|}
\hline & Temperatura otoczenia & Ciśnienie atmosferyczne \\
\hline$[-]$ & {$\left[{ }^{\circ} \mathrm{C}\right]$} & {$[\mathrm{hPa}]$} \\
\hline Średnia & 19,3 & 1003,9 \\
\hline Odchylenie standardowe & 0,7 & 0,7 \\
\hline Wartość max. & 20,3 & 1004,9 \\
\hline Wartość min. & 18,5 & 1003,0 \\
\hline
\end{tabular}

Źródło: Opracowanie własne.

Na podstawie kilkuset zarejestrowanych pomiarów wytypowano warunki, w których powinny odbywać się pomiary służące jako podstawa do diagnozowania motopompy.

1. Ze względu na wzajemne oddziaływania silnika i pompy oraz sposób pracy w rzeczywistych warunkach eksploatacji badania prowadzono na charakterystyce zewnętrznej, tzn. max. otwarcie przepustnicy i regulacja za pomocą dławienia przepływu.

2. Głębokość zasysania może być zmienna i najczęściej (w rzeczywistych warunkach operacyjnych) jest niewielka - pompa stoi na brzegu zbiornika wodnego, z którego zasysa wodę.

W związku z tym badania diagnostyczne prowadzono przy maksymalnym otwarciu przepustnicy. Na ryc. 3 przedstawiono charakterystyki parametrów diagnostycznych na charakterystyce zewnętrznej silnika, przy regulacji zaworu klapowego w linii tłocznej motopompy. Badania wykonywano, poczynając od maksymalnej wydajności zbudowanej linii tłocznej, stopniowo przymykając zawór klapowy, tak aby wymusić ciśnienia tłoczenia odpowiednio 1, 2, 3, 4, 5, 6, 7, 8 bar. Dla każdego punktu regulacji wykonano serię 10 pomiarów. Wyniki przedstawiono w formie wartości średnich poszczególnych parametrów.

W kolejnym etapie pomiarów badano wpływ wysokości ssania na wartości parametrów diagnostycznych. Badania wykonano dla trzech wysokości ssania: $0,95 \mathrm{~m}, 1,5 \mathrm{~m}$ oraz $1,77 \mathrm{~m}$, co ze względu na ograniczenia stanowiska badawczego było maksymalną głębokością ssania. Uzyskane wyniki przedstawiono na ryc. 4 oraz 5 . 


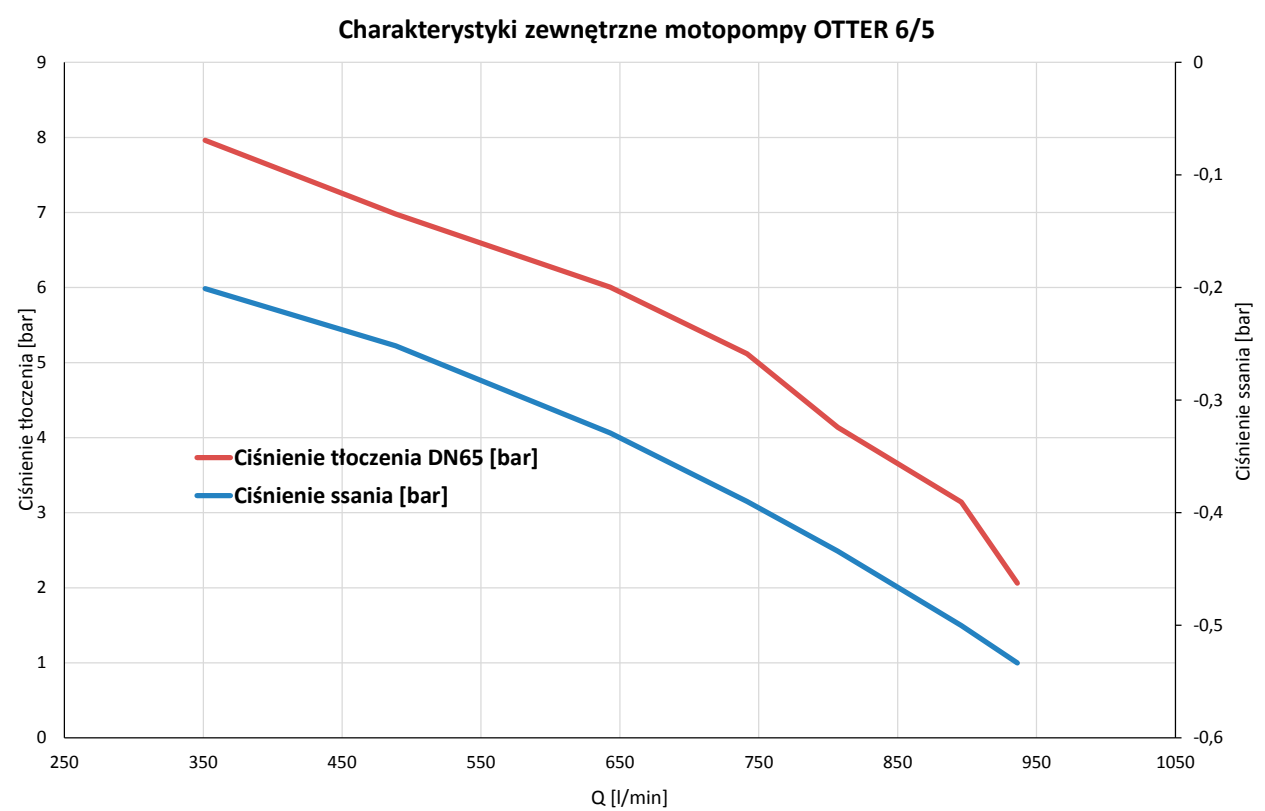

Ryc. 3. Charakterystyka ciśnienia tłoczenia i ssania w funkcji intensywności przepływu zdatnej Motopompy OTTER 6/5

Źródło: Opracowanie własne.

\section{Charakterystyka ciśnienia motopompy OTTER 6/5}

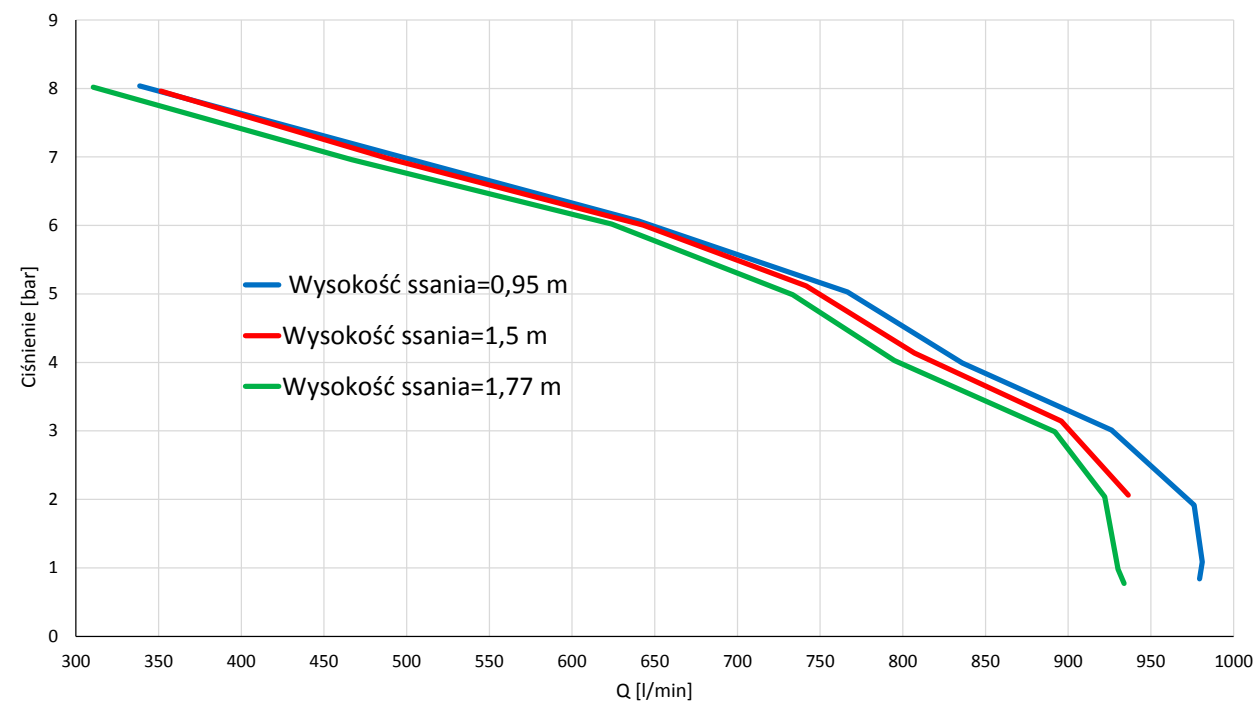

Ryc. 4. Charakterystyka ciśnienia tłoczenia w funkcji intensywności przepływu dla różnych głębokości ssania

Źródło: Opracowanie własne. 


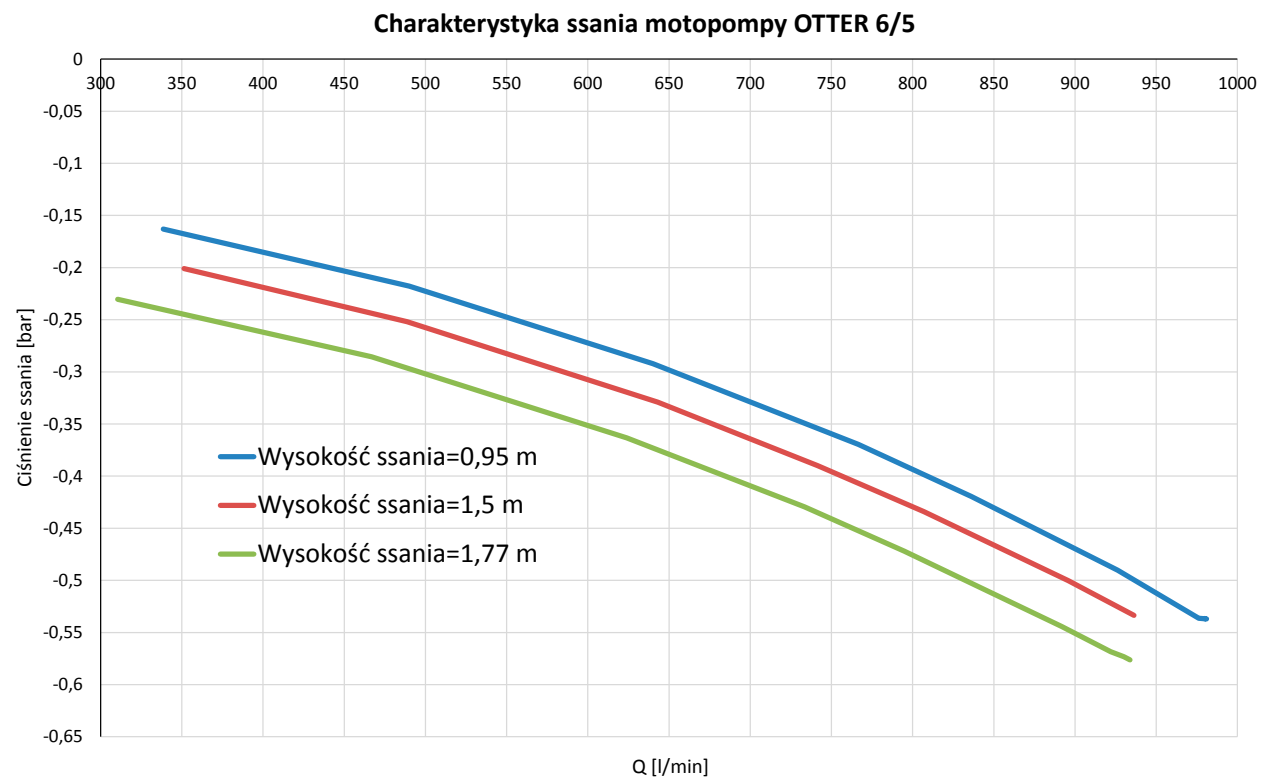

Ryc. 5. Charakterystyka ciśnienia ssania w funkcji intensywności przepływu dla różnych głębokości ssania

Źródło: Opracowanie własne.

\section{Podsumowanie}

W ramach badań wykonywanych w projekcie nr DOBR-BIO4/051/13087/2013 pn. „Opracowanie metodologii stałego nadzoru eksploatacji wybranych obszarów wyposażenia straży pożarnej w zakresie niezawodności i skuteczności działania":

- wyznaczono wzorcowe parametry diagnostyczne zdatnej motopompy OTTER 6/5 w punkcie nominalnym: $\mathrm{p}=6$ bar $\mathrm{Q}=500 \mathrm{l} / \mathrm{min}$;

- wyznaczono powtarzalności wzorcowych parametrów diagnostycznych zdatnej motopompy OTTER $6 / 5 \mathrm{w}$ punkcie nominalnym: $\mathrm{p}=6$ bar $\mathrm{Q}=500 \mathrm{l} / \mathrm{min}$. Należy stwierdzić, że rozrzut wyników określony odchyleniem standardowym wartości średniej jest na niskim poziomie, co zapewnia, że zmiany parametrów diagnostycznych na skutek uszkodzenia będą łatwo identyfikowalne;

- w trakcie przeprowadzania badań stwierdzono, że na potrzeby procesu diagnozowania sprawdzenia należy wykonywać przy charakterystyce zewnętrznej silnika motopompy;

- wyznaczono wzorcowe parametry diagnostyczne zdatnej motopompy OTTER 6/5 pracującej na zewnętrznej charakterystyce silnika; 
- wyznaczono wzorcowe parametry diagnostyczne zdatnej motopompy OTTER 6/5 pracującej na zewnętrznej charakterystyce silnika dla różnych głębokości ssania.

Zaproponowane parametry diagnostyczne w stałych warunkach badań charakteryzują się dużą powtarzalnością. Na podstawie zarejestrowanych pomiarów wytypowano warunki, w których powinny odbywać się pomiary służące jako podstawa do diagnozowania motopompy. 


\title{
EKSPLOATACJA RĘKAWÓW PRZECIWPOWODZIOWYCH
}

\author{
Dorota Riegert \\ Zuzanna Ślosorz \\ Adam Majka
}

\section{Wprowadzenie}

Eksploatacja to ogół operacji, których celem jest użytkowanie urządzeń w zakresie dedykowanego im zastosowania ${ }^{1}$.

Mianem powodzi określa się przejściowe zjawisko hydrologiczne w postaci gwałtownego przyboru wody, wynikiem którego są zalania, podtopienia lub zatopienia. Biorąc pod uwagę zasięg wystąpienia tego zjawiska, wyróżnia się powodzie opadowe, roztopowe, zatorowe lub sztormowe ${ }^{2}$.

Każde z państw narażonych na powódź ze względów klimatycznych oraz topograficznych stosuje odpowiednie środki mające na celu zapobieganie lub zminimalizowanie jej skutków. Przeciwdziałanie powodzi polega na stosowaniu różnego rodzaju systemów ochrony ${ }^{3}$. Optymalne prowadzenie gospodarki wodnej uzyskiwane jest $\mathrm{w}$ oparciu o stosowanie różnych metod związanych m.in. $\mathrm{z}$ ochroną przeciwpowodziową, ekonomiczną eksploatacją zasobów wodnych, produkcją energii oraz transportem. Przykładem tego typu rozwiązań jest racjonalne zagospodarowanie obszarów narażonych na podtopienia, zalania, powodzie, ubezpieczaniem zagrożonego mienia, organizowaniem sprawnego systemu ostrzeżeń oraz ewakuacji, oszczędzanie zasobów wód 4 .

Bezpośredni wpływ na efektywność realizowanych zadań dotyczących ochrony powodziowej mają zapisy zawarte $\mathrm{w}$ ustawach i rozporządzeniach odnoszących się do ochrony przeciwpożarowej w Polsce. Na ich podstawie zostały przydzielone kompetencje i obowiązki poszczególnych instytucji i służb w wyżej wymienionym zakresie. W Polsce system ochrony przeciwpowodziowej funkcjonuje na zasadzie korelacji instytucjonalno-prawnej poszczególnych jednostek

1 Zob. W. Kopaliński, Słownik wyrazów obcych i zwrotów obcojęzycznych, Oficyna Wydawnicza Rytm, Warszawa 2014.

2 Zob. D. Riegert, Doraźne metody ochrony przed powodzią, BiTP Vol. 35 Issue 3, 2014, pp. 139-147, DOI:10.12845/bitp.35.3.2014.13.

3 Zob. tamże.

4 Zob. R. Wawręty, J. Żelaziński, Zapory a powodzie, Wydawnictwo Towarzystwo na rzecz Ziemi, Polska Zielona Sieć, Oświęcim-Kraków 2006. 
administracyjnych. Schemat systemu ochrony przeciwpowodziowej został przedstawiony na ryc. $1^{5}$.

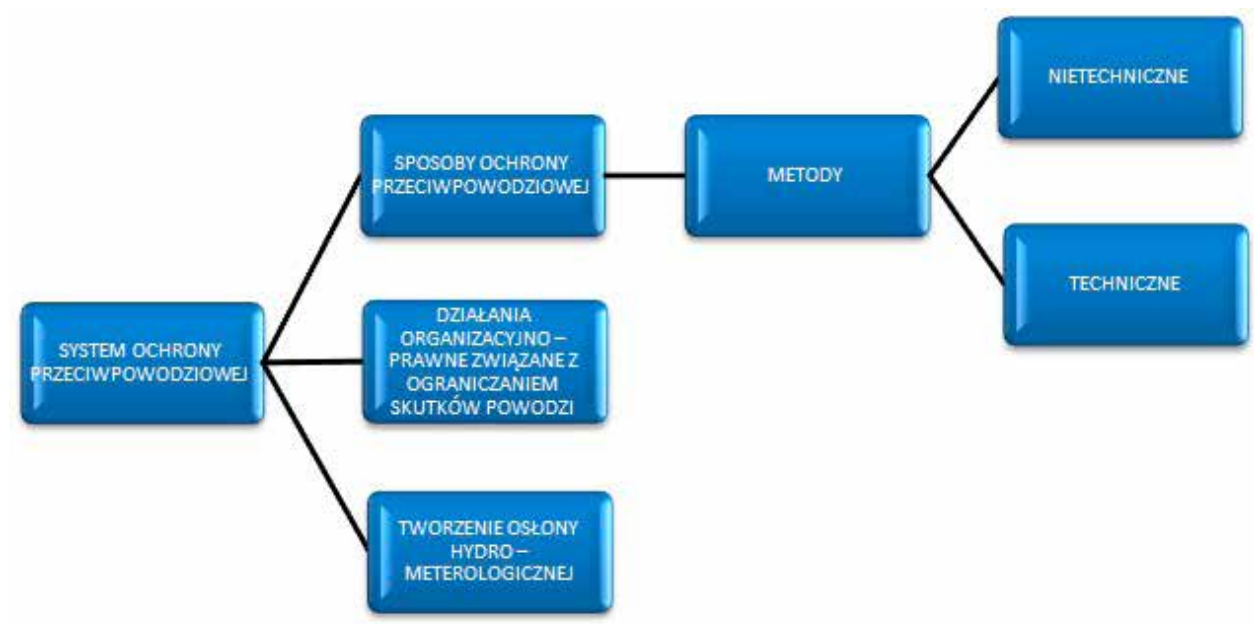

Ryc. 1. Koncepcja systemu ochrony przeciwpowodziowej

Źródło: R. Wawręty, J. Żelaziński, Zapory a powodzie, dz. cyt.

Środki ochrony przeciwpowodziowej można podzielić na środki stałe oraz doraźne ${ }^{6}$. Wśród stałych środków ochrony przeciwpowodziowej wyróżnić można:

- wały przeciwpowodziowe;

- poldery;

- zbiorniki retencyjne;

- kanały ulgi.

Natomiast do środków doraźnej ochrony przeciwpowodziowej zalicza się:

- worki z piaskiem;

- rękawy przeciwpowodziowe;

- bariery przeciwpowodziowe.

Wszystkie działania prowadzone w trakcie trwania lub bezpośrednio przed akcją przeciwpowodziową określa się mianem doraźnego zabezpieczenia przed powodzią. Zalicza się do nich między innymi wykorzystanie worków z piaskiem oraz rękawów przeciwpowodziowych ${ }^{7}$.

5 Zob. Z. Kowalewski, Powodzie w Polsce - rodzaje, występowanie oraz system ochrony przed ich skutkami, Woda-Środowisko-Obszary Wiejskie, t. 6, z. 1 (16), 2006, 207-220.

6 Zob. D. Riegert, Doraźne metody ochrony przed powodzia, dz. cyt.

7 Zob. tamże. 


\section{Doraźne metody ochrony przed powodzią}

Zapory z worków wypełnionych piaskiem są podstawową doraźną metodą ochrony przeciwpowodziowej. Podwyższanie korony wału przeciwpowodziowego lub ochrona zagrożonego terenu za pomocą zapór zbudowanych z worków z piaskiem są działaniami bardzo czasochłonnym. Aby były jak najbardziej efektywne, wymagają zaangażowania dużej grupy ludzi ${ }^{8}$. Dodatkowo do budowy tego typu zapór niezbędny jest piasek do napełnienia worków, który niejednokrotnie trzeba przywozić w miejsce prowadzenia akcji, co dodatkowo zwiększa jej koszty.

Na ryc. 2 przedstawiono sposób ułożenia worków z piaskiem. Worki po załadowaniu piaskiem do około 70\% objętości należy układać ściśle, jeden obok drugiego $\mathrm{z}$ wiązaniem uniesionym w górę. Każdy kolejny poziom ułożonych worków z piaskiem powinien być układany w sposób przypominający mur z cegieł9 .

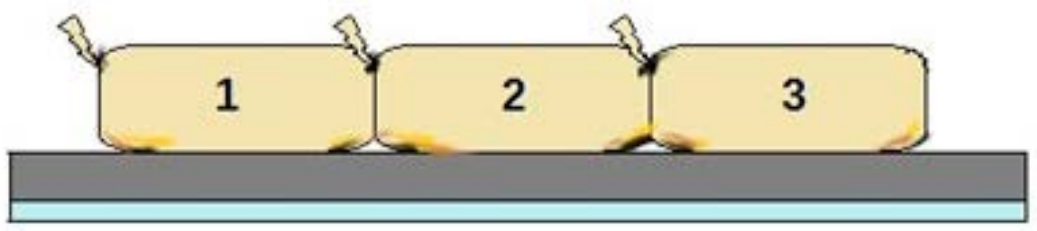

Ryc. 2. Sposób ułożenia worków z piaskiem $(1,2,3)$

Źródło: D. Riegert (red.), Doraźne metody ochrony stosowane podczas powodzi..., dz. cyt.

Alternatywnym sposobem doraźnego zabezpieczenia przed powodzią są rękawy przeciwpowodziowe, które w porównaniu do worków z piaskiem są stosunkowo tanie i nie wymagają dużej liczby sprzętu i ludzi do ich montażu ${ }^{10}$.

Głównym zastosowaniem rękawów przeciwpowodziowych jest wykorzystywanie ich do tworzenia zabezpieczeń przeciwpowodziowych. Oprócz tego materiały te można stosować jako ${ }^{11}$ :

- zabezpieczenie miejsc skażenia powierzchni wód substancjami ropopochodnymi (na płytkich wodach),

- tymczasowe zbiorniki:

- do przewożenia wody do akcji ratowniczej,

- na substancje niebezpieczne.

Rękawy przeciwpowodziowe najczęściej produkowane są z różnego rodzaju gumowanych tkanin polimerowych lub tkanin polimerowych zbrojonych stalowymi siatkami.

8 Zob. J. Szylar, Szkolenie Strażaków Ratowników OSP z zakresu działań przeciwpowodziowych oraz ratownictwa na wodach, CNBOP, Józefów 2009.

9 Zob. D. Riegert (red.), Doraźne metody ochrony stosowane podczas powodzi ze szczególnym uwzględnieniem rękawów przeciwpowodziowych, CNBOP-PIB, Józefów 2012.

10 Zob. tamże.

11 Zob. tamże. 
Materiały, z których wytwarzane są rękawy przeciwpowodziowe, powinny być odporne na promieniowanie UV, działanie substancji chemicznych oraz wykazywać wysoką wytrzymałość materiałową, tj. nie powinny szybko ulegać uszkodzeniu $\mathrm{w}$ trakcie użytkowania. W przypadku uszkodzenia, w celu przedłużenia funkcjonalności, rękaw należy obłożyć workiem z piaskiem ${ }^{12}$.

Rękawy przeciwpowodziowe można podzielić ze względu na rodzaj przekroju po ich napełnieniu (rękawy o przekroju kołowym lub trapezowym) oraz ze względu na liczbę komór (jednokomorowe, dwukomorowe, wielokomorowe) ${ }^{13}$.

Wyróżnia się rękawy przeciwpowodziowe jednokomorowe o przekroju kołowym lub trapezowym. Rękawy o przekroju kołowym mają różny rozmiar i można je podzielić na ${ }^{14}$ :

a) rękawy o przekroju kołowym $\mathrm{z}$ relingami i fartuchem,

b) rękawy o przekroju kołowym napełniane specjalnymi mieszankami (stałe lub tymczasowe),

c) rękawy o przekroju kołowym, pionowe.

Rękawy przeciwpowodziowe dwukomorowe można podzielić na rękawy o przekroju kołowym lub trapezowym (o różnym rozmiarze).

Wśród rękawów przeciwpowodziowych wielokomorowych wyróżnia się rękawy stałe lub tymczasowe o przekroju kołowym napełniane specjalnymi mieszankami.

W zależności od zapotrzebowania wytwarza się rękawy o różnej długości (od $1 \mathrm{~m}$ do $25 \mathrm{~m}$ ), odporności na temperaturę (od $-35^{\circ} \mathrm{C}$ do $+70^{\circ} \mathrm{C}$ ) oraz czasie użytkowania (do 15 lat). Konserwacja rękawów przeciwpowodziowych polega na każdorazowym wyczyszczeniu, osuszeniu i sprawdzeniu powierzchni w celu wykrycia ewentualnych zmian powierzchni użytkowej.

Zaletami rękawów przeciwpowodziowych są ich mobilność oraz możliwość ustawiania na różnorodnym podłożu nienarażającym swoją strukturą na uszkodzenie ich powierzchni. Przy napełnianiu rękawów przeciwpowodziowych należy zwrócić uwagę na nachylenie terenu oraz położenie kanału wlewowego. Powinien się on znajdować w najwyższym punkcie podłoża, na którym rozkładane są rękawy. Do napełnienia rękawów przeciwpowodziowych niezbędny jest sprzęt napełniający i pomocniczy m.in. łączniki, rozdzielacze, węże pożarnicze, motopompy. Należy zaznaczyć, że rękawy przeciwpowodziowe stosuje się w przypadku, gdy przewidywana głębokość wody nie będzie większa od wysokości wyrobu. Wał ułożony z rękawów przeciwpowodziowych można podwyższyć poprzez ułożenie piramidy 15 .

\footnotetext{
12 Zob. tamże.

13 Zob. tamże.

14 Zob. tamże.

15 Zob. tamże.
} 
Poniżej przedstawiono system układania rękawów przeciwpożarowych. Można wyróżnić piramidę o podstawie $\mathrm{z}$ dwóch lub trzech rękawów przeciwpowodziowych (ryc. 3).

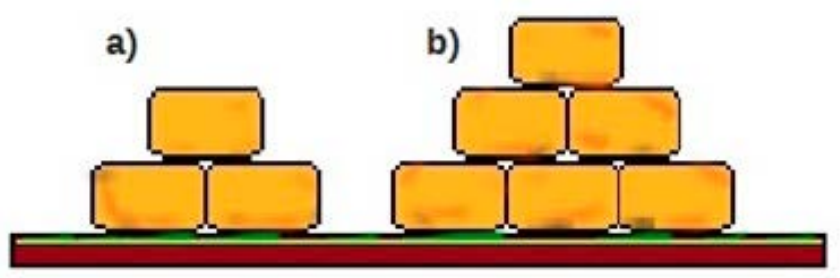

Ryc. 3. System układania rękawów przeciwpowodziowych w sposób piramidalny w celu zwiększenia wysokości zabezpieczenia a) na podstawie z dwóch rękawów przeciwpowodziowych b) na podstawie $\mathrm{z}$ trzech rękawów przeciwpowodziowych

Źródło: D. Riegert (red.), Doraźne metody ochrony stosowane podczas powodzi..., dz. cyt.

W celu zwiększenia stabilności niektóre typy rękawów przeciwpowodziowych podczas układania ich $\mathrm{w}$ sposób piramidalny należy spinać specjalnymi pasami lub relingami. Natomiast rękawy wytworzone w trakcie realizacji projektu „Optymalizacja procedur, dyslokacji baz i doskonalenie rozwiązań technicznych sprzętu stosowanego przez polskie służby ratownicze $\mathrm{w}$ zakresie przeciwdziałania zagrożeniom naturalnym ze szczególnym uwzględnieniem powodzi (rękawy przeciwpowodziowe)" do tego celu posiadają specjalny łącznik, a ich specyficzna budowa dodatkowo zapewnia stabilność konstrukcji16.

Poniżej zestawiono wady i zalety rękawów przeciwpowodziowych.

Zalety rękawów przeciwpowodziowych ${ }^{17}$ :

- nieskomplikowana budowa;

- łatwy i szybki montaż/demontaż (napełnianie i opróżnianie);

- kompatybilność elementów konstrukcyjnych ze sprzętem stosowanym przez służby ratownicze;

- niewielka liczba osób niezbędna do montażu/demontażu;

- możliwość budowania dowolnej długości wałów;

- możliwość zwiększenia wysokości zapór (odpowiedni system ułożenia rękawów);

- możliwość transportu rękawów;

- niska waga.

Wady rękawów przeciwpowodziowych ${ }^{18}$ :

- brak szkoleń służb ratowniczych w tym zakresie;

- trudność z czyszczeniem, suszeniem i dekontaminacją;

- problem z utylizacją; 
- uszkodzenie napełnionych rękawów na miejscu akcji praktycznie uniemożliwia ich dalsze stosowanie;

- nie można używać rękawów przeciwpowodziowych do podwyższania nasiąkniętych wodą wałów przeciwpowodziowych (zbyt duża masa).

\section{Sprawianie rękawów przeciwpowodziowych}

Rozstawianie rękawów przeciwpowodziowych zwane sprawianiem wymaga dużej precyzji i ostrożności. Należy pamiętać, że rękawy w głównej mierze wytwarzane są z materiałów o stosunkowo niskiej odporności na przebicia i uszkodzenia mechaniczne, dlatego przed ich sprawianiem należy dokładnie przygotować pod nie teren. Wyznaczony pod rozstaw rękawów teren należy oczyścić z patyków, gałęzi i ostrych przedmiotów. W przypadku zaistnienia konieczności sprawiania rękawów np. na świeżo skoszonych wałach przeciwpowodziowych lub rżysku należy rozważyć wcześniejsze rozłożenie dodatkowej folii ochronnej i na niej sprawiać rękawy.

Podczas sprawiania rękawów należy je uważnie układać, z zachowaniem zasad bezpiecznego postępowania napełnić rękawy medium - np. wodą. Należy pamiętać, że powinny być one układane w miarę możliwości na poziomej płaszczyźnie tak, by uniknąć ich staczania się - np. z korony wału (ryc. 4).
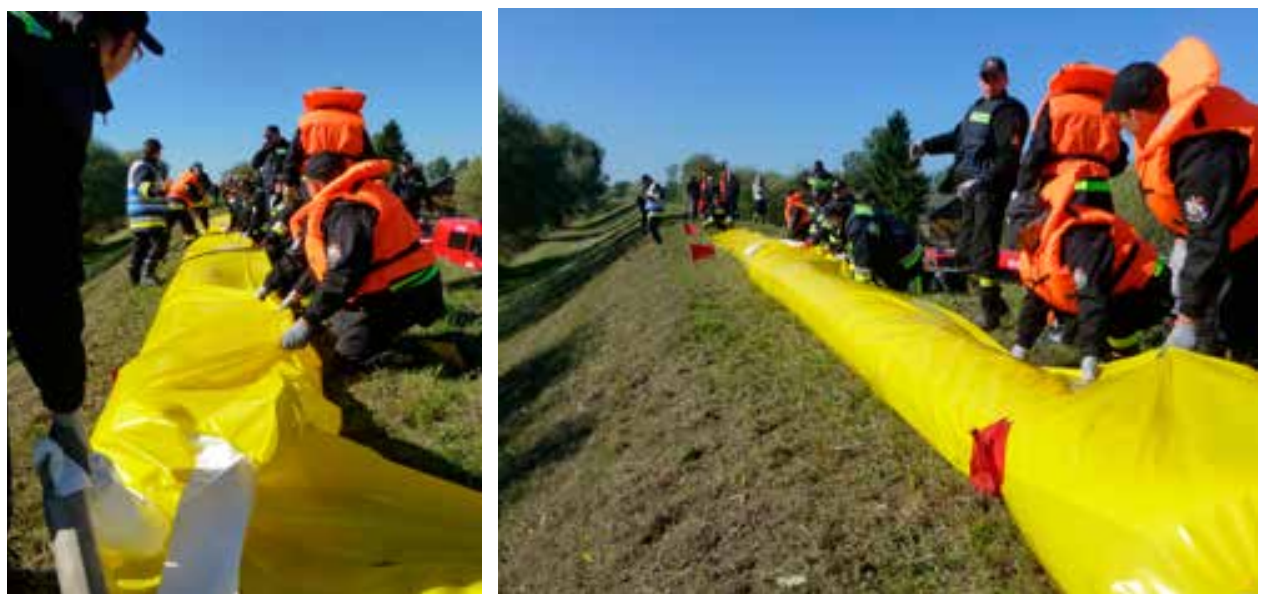

Ryc. 4. Staczanie się rękawa podczas nieprawidłowo prowadzonego procesu sprawiania Źródło: Wyk. D. Riegert.

Dodatkowo w rękawach przeciwpowodziowych wytworzonych w ramach realizacji projektu „Optymalizacja procedur, dyslokacji baz i doskonalenie rozwiązań technicznych sprzętu stosowanego przez polskie służby ratownicze w zakresie przeciwdziałania zagrożeniom naturalnym ze szczególnym uwzględnieniem powodzi (rękawy przeciwpowodziowe)" należy zwrócić szczególną uwagę na kanały wlewowe oraz rozkładać rękaw przed napełnianiem tak, by go nie skręcić, bowiem skręcenie wewnętrznego rękawa znacznie obniża stabilność zapory (ryc. 5). 


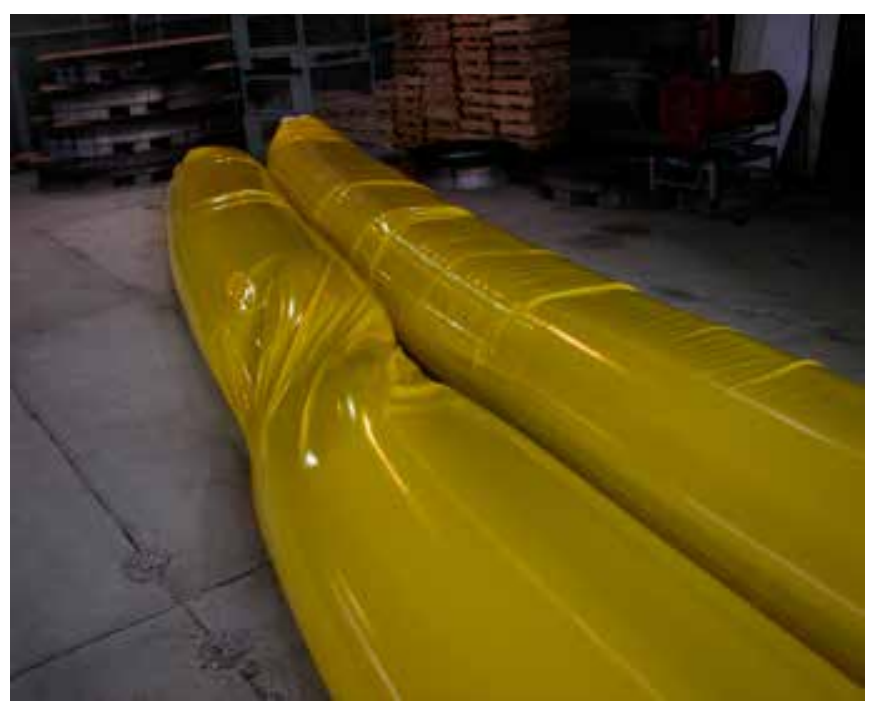

Ryc. 5. Nieprawidłowo sprawiony rękaw przeciwpowodziowy ze skręconym rękawem wewnętrznym

Źródło: Wyk. D. Riegert.

W przypadku konieczności piętrowania rękawów przeciwpowodziowych niezwykle ważne jest układanie ich blisko siebie. Po sprawieniu jednego rękawa drugi należy ułożyć bardzo blisko pierwszego tak, by po sprawieniu ściśle do siebie przylegały. Prawidłowe ścisłe ułożenie dwóch dolnych rękawów będzie stanowiło stabilną płaszczyznę dla trzeciego, który ma zostać na nich sprawiony. W przypadku pojawienia się przerwy między dwoma dolnymi rękawami (ryc. 6) w wyniku niespełnienia tego warunku, trzeci ułożony na nich „wciśnie się” pomiędzy nie (ryc. 7), co spowoduje, że nie zostanie osiągnięta odpowiednia wysokość zapory i zabezpieczany teren może ulec zalaniu.

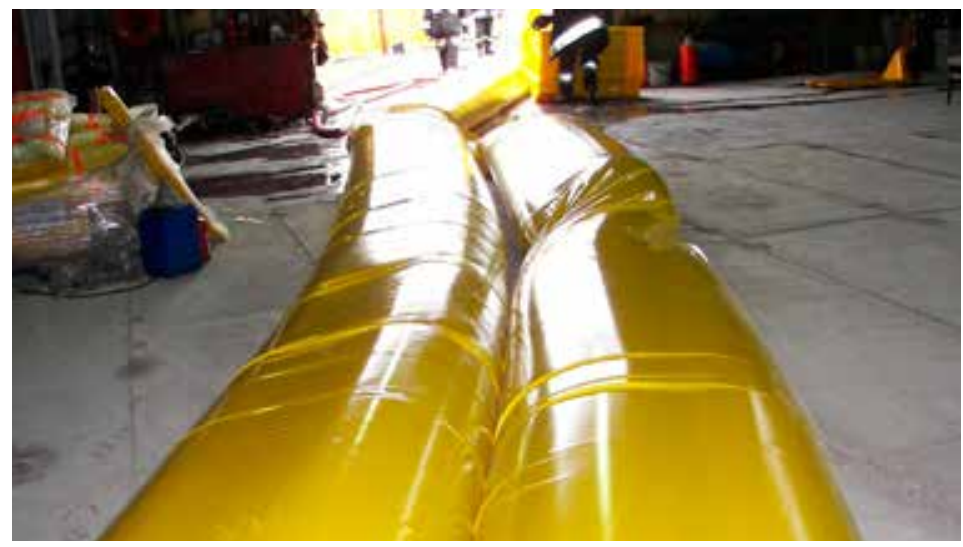

Ryc. 6. Za luźne ułożenie rękawów

Źródło: Wyk. D. Riegert. 


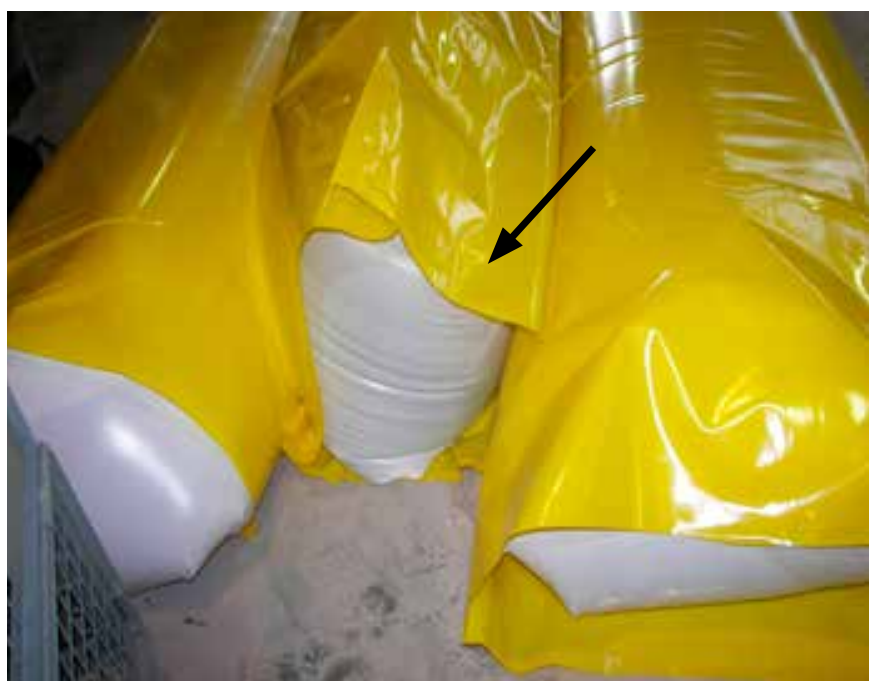

Ryc. 7. „Wciśnięcie się” górnego rękawa pomiędzy dolne

Źródło: Wyk. D. Riegert.

\section{Dekontaminacja rękawów przeciwpowodziowych}

Po zakończeniu prowadzenia akcji ratowniczej podczas powodzi cały sprzęt, w tym również rękawy przeciwpowodziowe, należy poddać dekontaminacji.

Dekontaminacja oznacza $z$ łaciny odkażanie ${ }^{19}$. Proces dekontaminacji polega na całkowitej dezaktywacji i usunięciu szkodliwych substancji zagrażających ludziom i środowisku naturalnemu. W sytuacji kryzysowej jest to niezmiernie ważny etap użytkowania wszelkiego rodzaju sprzętu. W trakcie powodzi mamy do czynienia z czynnikami skażającymi różnego pochodzenia, między innymi pochodzącymi $z^{20}$ :

- wysypisk odpadów komunalnych,

- dzikich składowisk,

- oczyszczalni ścieków,

- szamb,

- zbiorników technicznych,

19 Zob. G. Krause, ABC dekontaminacji, „Przegląd Pożarniczy”, 11 (2006), 22; Zob. D. Riegert, P. Suchorab, Istota dekontaminacji, materiały konferencyjne: IV Międzynarodowa Konferencja Naukowo-Techniczna nt. „Nowoczesne miasta. Infrastruktura i środowisko” INFRAEKO 2014.

${ }^{20}$ Zob. Z. Salomonowicz, I. Naworol, Zebranie literatury i sprecyzowanie założeń kierunku prowadzenia dekontaminacji wewnętrznej i zewnętrznej rękawów, Sprawozdanie z realizacji projektu „Optymalizacja procedur, dyslokacji baz i doskonalenie rozwiązań technicznych sprzętu stosowanego przez polskie służby ratownicze w zakresie przeciwdziałania zagrożeniom naturalnym ze szczególnym uwzględnieniem powodzi (rękawy przeciwpowodziowe)", Warszawa 2012. 
- piwnic,

- cmentarzy,

- ścieków miejskich i przemysłowych,

- składników z obiektów rolniczych (kiszonki, gnojowice, nawozy sztuczne),

- składów budowlanych.

Woda powodziowa zawiera trzy główne grupy zanieczyszczeń: chemiczne, biologiczne oraz inne zanieczyszczenia stałe. Wśród czynników skażających przede wszystkim należy wymienić 21 :

- bakterie,

- wirusy,

- cysty pasożytnicze,

- grzyby,

- glony,

- związki chemiczne,

- inne zanieczyszczenia stałe organiczne i nieorganiczne.

Podczas dekontaminacji stosuje się neutralizatory, które po dodaniu do szkodliwego związku zobojętniają go poprzez zmniejszenie jego toksyczności. Stopień neutralizacji związków toksycznych bywa różny, a neutralizator może znacznie ograniczyć agresywność takiej substancji. Strażacy stosują wiele uniwersalnych związków neutralizujących, które mają szerokie spektrum działania na różne substancje niebezpieczne (tabela 1 i 2 ).

TABELA 1

Skład podstawowych roztworów dekontaminacyjnych

\begin{tabular}{|c|c|}
\hline $\begin{array}{c}\text { Nazwa roztworu } \\
\text { dekontaminacyjnego }\end{array}$ & Skład roztworu dekontaminacyjnego \\
\hline RD 1 & $\begin{array}{r}\text { 5-proc. roztwór węglanu sodowego } \mathrm{Na}_{2} \mathrm{CO}_{3} \\
\text { i 5\% roztwór fosforanu sodowego } \mathrm{Na}_{3} \mathrm{PO}_{4}\end{array}$ \\
\hline RD 2 & 10-proc. roztwór podchlorynu wapniowego $\mathrm{Ca}(\mathrm{ClO})_{2}$ \\
\hline RD 3 & 5-proc. roztwór fosforanu sodowego $\mathrm{Na}_{3} \mathrm{PO}_{4}$ \\
\hline RD 4 & 1-proc. roztwór kwasu solnego $\mathrm{HCl}$ \\
\hline RD 5 & wodny roztwór detergentu najlepiej domowego użytku \\
(mydła, detergenty, proszki do prania lub ZPC)
\end{tabular}

Źródło: Materiały edukacyjne SGSP w Warszawie, https://www.sgsp.edu.pl/uczelnia/kdrg/ zrch/cw/dekon_sorb.pdf, [Dostęp: 31.07.2013]

${ }^{21}$ Zob. tamże. 
Zastosowanie roztworów dekontaminacyjnych

\begin{tabular}{|c|c|c|}
\hline Lp. & Rodzaj skażenia & $\begin{array}{c}\text { Nazwa roztworu } \\
\text { dekontaminacyjnego }\end{array}$ \\
\hline 1. & nieorganiczne kwasy, odpady powstałe wskutek przeróbki metali & $\mathrm{RD} 1$ \\
\hline 2. & metale ciężkie i ich sole & $\mathrm{RD} 2$ \\
\hline 3. & $\begin{array}{l}\text { pestycydy, chlorowane bifenyle, chlorowane fenole, środki } \\
\text { chwastobójcze }\end{array}$ & $\mathrm{RD} 2$ \\
\hline 4. & cyjanki, amoniaki i inne niekwaśne nieorganiczne odpady & RD 2 \\
\hline 5. & $\begin{array}{l}\text { rozpuszczalniki i zw. org. tj. trójchloroetan, toluen, } \\
\text { trójchloroform }\end{array}$ & RD 1 lub 3 \\
\hline 6. & dwufenyle polichlorowane i polibromowane & RD 1 lub 3 \\
\hline 7. & $\begin{array}{l}\text { oleje natłuszczone i inne niewymienione odpady nie skażone } \\
\text { pestycydami }\end{array}$ & $\mathrm{RD} 3$ \\
\hline 8. & $\begin{array}{l}\text { nieorganiczne zasady ( wodorotlenki ), alkaliczne i żrące } \\
\text { odpady }\end{array}$ & $\mathrm{RD} 4$ \\
\hline 9. & materiały radioaktywne & RD 5 \\
\hline 10. & materiały chorobotwórcze & RD 1 lub 2 \\
\hline
\end{tabular}

Źródło: Materiały edukacyjne SGSP w Warszawie, https://www.sgsp.edu.pl/uczelnia/kdrg/ zrch/cw/dekon_sorb.pdf, [Dostęp: 31.07.2013].

W przypadku dekontaminacji rękawów przeciwpowodziowych po ich demontażu - opróżnieniu z medium, należy ułożyć każdy z nich osobno w kuwecie dekontaminacyjnej i do jego wnętrza podać odpowiedni środek odkażający. Następnie należy opróżnić rękaw i wypłukać go czystą wodą. Czynność odkażania należy również przeprowadzić na powierzchni zewnętrznej rękawa - do czyszczenia można użyć szczotki lub urządzenia ciśnieniowego. Po dokładnym umyciu i opłukaniu rękawa należy go dokładnie wysuszyć, złożyć i przygotować do magazynowania.

Nie wszystkie rękawy przeciwpowodziowe można poddawać dekontaminacji całkowitej. W przypadku rękawów przeciwpowodziowych opracowanych w projekcie „Optymalizacja procedur, dyslokacji baz i doskonalenie rozwiązań technicznych sprzętu stosowanego przez polskie służby ratownicze w zakresie przeciwdziałania zagrożeniom naturalnym ze szczególnym uwzględnieniem powodzi (rękawy przeciwpowodziowe)" nie ma możliwości dekontaminacji całego rękawa. Spowodowane jest to jego unikalną budową. Rękaw ten składa się z dwóch rękawów wykonanych $\mathrm{z}$ folii polietylenowej PE, z czego jeden stanowi rękaw zewnętrzny o długości $11 \mathrm{~m}$, a drugi stanowi rękaw wewnętrzny i jest ułożony w zewnętrznym w kształt litery „U”. Rękaw wewnętrzny ma długość około 23 m i zwężone kanały wlewowe. Rozwiązanie takie powoduje, że niemożliwa jest dokładna dekontaminacja rękawa wewnętrznego. W związku $\mathrm{z}$ tym $\mathrm{w}$ ramach tego rozwiązania stosuje się jedynie dekontaminację rękawa zewnętrznego, a rękaw wewnętrzny wymienia się na nowy. Zewnętrzny rękaw należy ułożyć w kuwecie dekontaminacyjnej oraz przy użyciu 
szczotki i urządzenia ciśnieniowego oraz z wykorzystaniem odpowiedniego środka dekontaminacyjnego poddać go czyszczeniu (ryc. 8), a następnie osuszyć ścierką. Następnie należy uzupełnić rękaw zewnętrzny o nowy rękaw wewnętrzny, złożyć go i przechowywać w magazynie.

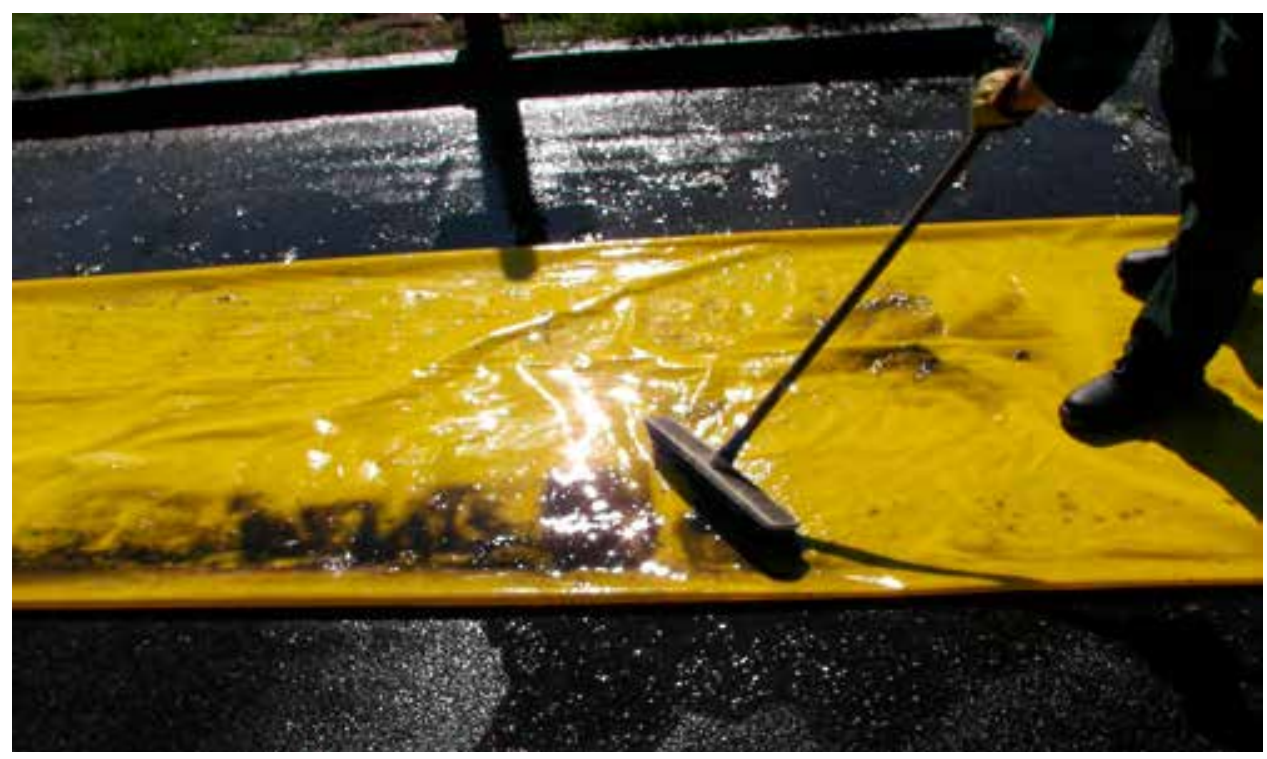

Ryc. 8. Czyszczenie rękawa przeciwpowodziowego

Źródło: Wyk. D. Riegert.

\section{Recykling rękawów przeciwpowodziowych}

Rękawy przeciwpowodziowe cieszą się coraz większą popularnością wśród strażaków i coraz chętniej są wykorzystywane podczas akcji przeciwpowodziowych. Między innymi dlatego niezmiernie ważnym zagadnieniem jest również ich recykling. Metody recyklingu rękawów w głównej mierze zależą od materiału, z którego rękaw został wykonany. W przypadku rękawów zbudowanych np. ze wzmocnionej, dwustronnie gumowanej tkaniny poliestrowej czy z tkanin zbrojonych siatkami recykling jest utrudniony. Natomiast w przypadku rękawów przeciwpowodziowych opracowanych w ramach realizacji projektu „Optymalizacja procedur, dyslokacji baz i doskonalenie rozwiązań technicznych sprzętu stosowanego przez polskie służby ratownicze w zakresie przeciwdziałania zagrożeniom naturalnym ze szczególnym uwzględnieniem powodzi (rękawy przeciwpowodziowe)" możliwy jest pełen recykling. Po uszkodzeniu rękawa lub wymianie rękawa wewnętrznego należy element ten odesłać do producenta, który po odpowiednim przygotowaniu podda go recyklingowi. Proces ten rozpoczyna się od podzielenia rękawa na rękaw zewnętrzny i rękaw wewnętrzny, ponieważ każdy z nich oddzielnie poddaje się procesowi recyklingu. Przygotowane rękawy należy 
poddać utylizacji w odpowiednim urządzeniu przeznaczonym do tego celu według poniższego schematu (ryc. 9).

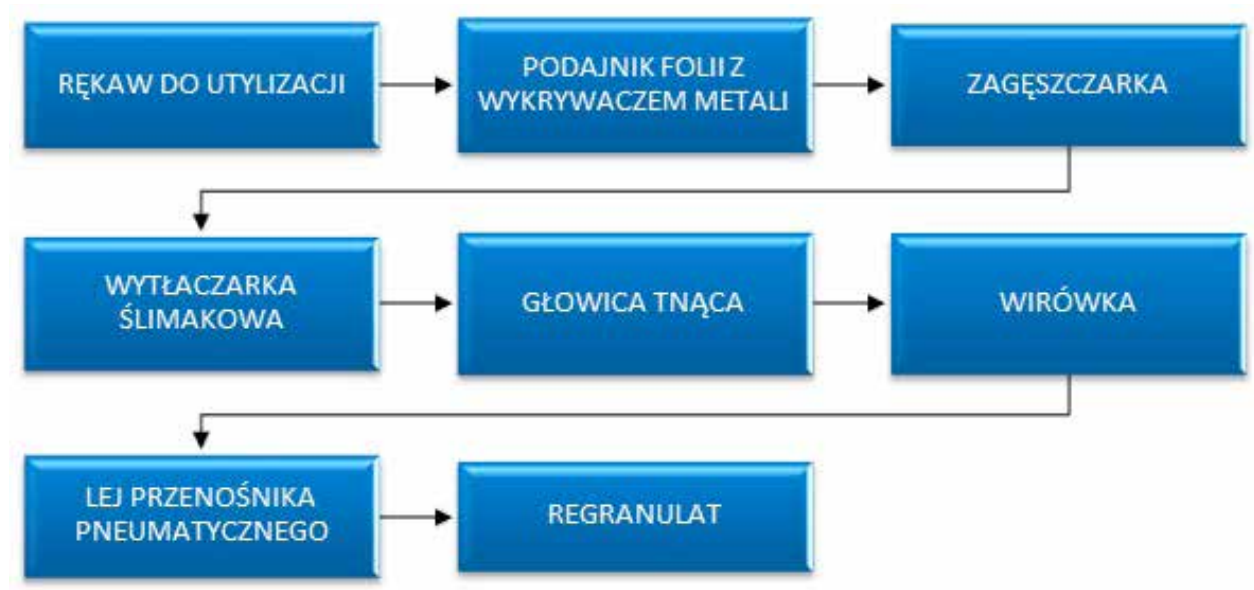

Ryc. 9. Schemat blokowy recyklingu rękawów wykonanych z folii PE Źródło: Opracowanie własne.

Rękaw poddawany recyklingowi pocięty na mniejsze kawałki (ok. $1 \mathrm{~m}$ długości) podajnikiem taśmowym trafia do tzw. zagęszczarki, gdzie folia jest cięta i rozdrabniana w temperaturze około $95^{\circ} \mathrm{C}$. Rozdrobniona folia w formie „płatków” (ryc. 10) trafia do wytłaczarki ślimakowej i poprzez działanie podwyższonej temperatury (w tym przypadku ok. $230^{\circ} \mathrm{C}$ ) ulega uplastycznieniu. Następnie plastyczna masa polietylenowa zostaje pocięta przez głowicę tnącą i wysuszona w wirówce, skąd poprzez lej przenośnika pneumatycznego w postaci regranulatu (ryc. 11) trafia np. do worków typu big-bag.

Regranulat otrzymany w procesie recyklingu tych rękawów następnie wykorzystywany jest do produkcji innych folii o mniejszym znaczeniu strategicznym takich jak np. worki na śmieci.

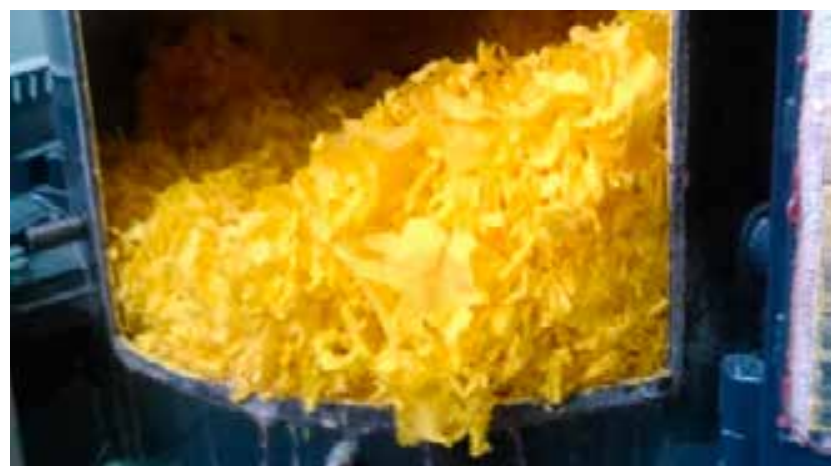

Ryc. 10. Rozdrobniona folia w formie "płatków”

Źrodło: Wyk. D. Riegert. 


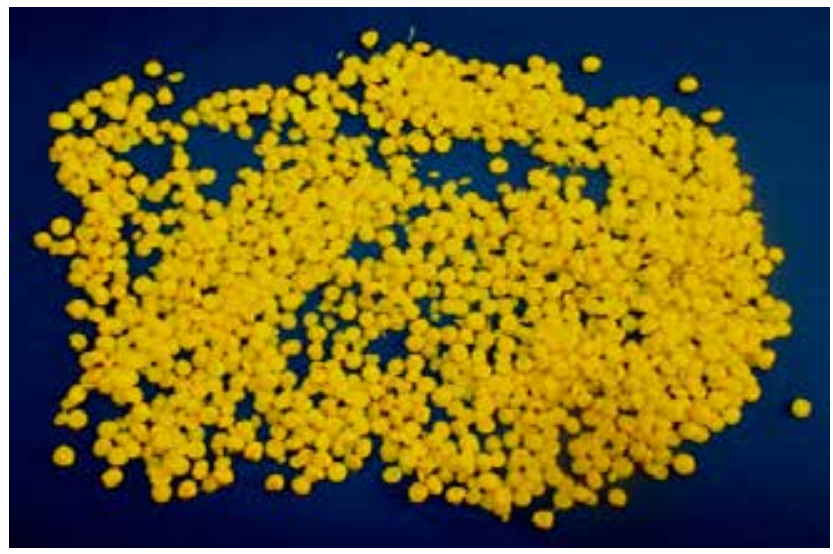

Ryc. 11. Regranulat polietylenowy

Źrodło: Wyk. D. Riegert.

\section{Wnioski}

Eksploatacja rękawów przeciwpowodziowych obejmuje wiele istotnych płaszczyzn takich jak: użytkowanie, dekontaminacja oraz recykling. Wszystkie te etapy nastręczają wiele problemów, a każdy z nich jest jednakowo ważny. Pierwszy etap - sprawianie rękawów przysparza strażakom wiele kłopotów. Spowodowane to jest mnogością występujących na rynku typów rękawów oraz niejednokrotnie brakiem szkoleń w tym zakresie. Podczas sprawiania rękawów należy postępować zgodnie $\mathrm{z}$ zaleceniami producenta w celu uniknięcia błędów, które mogą skutkować np. zalaniem chronionych terenów ze względu na nieotrzymanie wymaganej wysokości stawianej zapory.

Następnym trudnym etapem działań po zakończeniu prowadzenia akcji ratowniczej z użyciem rękawów przeciwpowodziowych jest ich dekontaminacja. Dobór odpowiednich środków odkażających oraz przeprowadzenie całego procesu oczyszczania i dezaktywacji substancji skażających jest istotne z punktu widzenia bezpieczeństwa ekologicznego oraz dalszej możliwości stosowania rękawów. Podczas tego etapu działań należy pamiętać o zbieraniu ścieków podekontaminacyjnych oraz ich utylizacji, co ma duże znaczenie dla środowiska.

Ważnym etapem, kończącym tak zwany „cykl życia”, jest recykling rękawów przeciwpowodziowych, który w zależności od materiałów stosowanych do wytwarzania powoduje konieczność stosowania różnych metod ich utylizacji.

W związku z tym, że rękawy przeciwpowodziowe coraz częściej wykorzystywane są $\mathrm{w}$ trakcie powodzi przez służby kryzysowe do ratowania terenów przed zalewaniem, niezmiernie ważne jest prowadzenie prac nad doskonaleniem poszczególnych etapów eksploatacji rękawów przeciwpowodziowych, ze szczególnym 
uwzględnieniem szkoleń obejmujących swym zakresem ich sprawianie oraz dekontaminację. Istotne jest również opracowywanie i doskonalenie technologii recyklingu i utylizacji rękawów przeciwpowodziowych po ich uszkodzeniu.

Projekt jest realizowany w konsorcjum, w skład którego wchodzą następujące instytucje: Instytut Technologii Bezpieczeństwa MORATEX (Lider projektu), Centrum Naukowo-Badawcze im. Józefa Tuliszkowskiego Państwowy Instytut Badawczy, Szkoła Główna Służby Pożarniczej, Wyższa Szkoła Zarządzania i Prawa im. Heleny Chodkowskiej w Warszawie, AMZ Kutno, Delta Rescue, Z.P.Chr. P.P.H.U. „Lester”. 


\section{Część II}

NOWOCZESNE ROZWIĄZANIA OCHRON OSOBISTYCH DLA SEUŻB RATOWNICZYCH KSRG

W OPARCIU O POTRZEBY UŻYTKOWNIKÓW KOŃCOWYCH 



\title{
PROBLEMY ZWIĄZANE Z OCENĄ OCHRON OSOBISTYCH PODDANYCH OBCIĄŻENIU CIEPLNEMU
}

\author{
Tomasz Wiśniewski \\ Piotr Furmański \\ Piotr Łapka
}

\section{Wprowadzenie}

Najistotniejszym zadaniem ochron osobistych, w tym odzieży ochronnej, jest zabezpieczenie strażaka przed oparzeniem $w$ wyniku oddziaływania otwartego płomienia, promieniowania cieplnego lub kontaktu z ciałami o podwyższonej temperaturze. Źródła ciepła i obciążenia cieplne od nich pochodzące mogą być zatem charakteryzowane wartościami gęstości strumienia ciepła i temperatury. Badania normowe przewidują określone procedury pomiarowe i współczynniki charakteryzujące badane materiały pod kątem ochrony przed poparzeniem. Wnikliwa analiza stosowanych metod wskazuje, że pozwalają one porównać badane materiały, lecz niekoniecznie wskazać np. czas wystąpienia oparzenia II stopnia w danych warunkach. Badania zawilgoconych pakietów odzieży ochronnej nie są powszechnie przyjętą normą. Obecność wody pogarsza ich efektywną izolacyjność cieplną, jak również powoduje ryzyko oparzeń parą wodną w przypadku kontaktu ubrania z ciałami o podwyższonej temperaturze. Wyniki symulacji numerycznych ${ }^{1}$ wskazują jednak, że obecność wilgoci w zależności od udziału masowego, rozkładu w warstwach odzieży i obciążenia cieplnego może zarówno pogarszać, jak i polepszać ochronę przed działaniem wysokich temperatur.

Polskie normy nie przewidują badań pojemności cieplnej odzieży ochronnej. Ciepło zmagazynowane w zewnętrznych warstwach ubrania może być w pewnych warunkach przyczyną oparzeń. Można również zauważyć, iż tylko sporadycznie prowadzone są badania używanej odzieży ochronnej. Należy zaznaczyć, iż przedmiotem zainteresowania autorów są metody badawcze zmierzające do oceny skuteczności zabezpieczenia ratownika przed oparzeniem. Nie są analizowane pozostałe normy i metody badawcze, które mają zastosowanie do oceny innych właściwości ochron osobistych.

1 K. Prasad, W. Twilley, J.R. Lawson, Thermal Performance of Fire Fighters' Protective Clothing. 1. Numerical Study of Transient Heat and Water Vapor Transfer, NISTIR 6881, August 2002. 


\section{Metody normowe stosowane do oceny odzieży ochronnej strażaków}

Poniżej scharakteryzowane zostaną wybrane normowe metody pomiarowe i wskaźniki stosowane w Polsce i w Stanach Zjednoczonych AP w badaniach odzieży ochronnej podlegającej obciążeniom cieplnym.

- Polska Norma PN-EN ISO 367 (styczeń 1996): Odzież ochronna. Ochrona przed ciepłem i promieniowaniem. Metoda wyznaczania przenikania ciepła przy działaniu płomienia. W normie tej stosowany jest wskaźnik przenikania ciepła HTI, definiowany jako średni czas w sekundach wzrostu temperatury o $(24,0 \pm 0,2)^{\circ} \mathrm{C}$ płyty miedzianej o masie $(18,00 \pm 0,05) \mathrm{g}$ i temperaturze początkowej $(25,0 \pm 5,0)^{\circ} \mathrm{C}$, przylegającej do próbki. Źródłem ciepła jest płomień o gęstości strumienia ciepła $80 \mathrm{~kW} / \mathrm{m}^{2} \mathrm{z}$ palnika gazowego umieszczonego pod próbką. Metoda ta pozwala na porównanie przenikania ciepła przez materiały lub warstwy materiałów stosowanych do produkcji odzieży ochronnej i ich klasyfikację w 5 klasach jakościowych. Wskaźnika przenikania ciepła HTI nie można jednak traktować jako czasu ochrony przed oparzeniem podczas rzeczywistego użytkowania.

- Polska Norma PN-EN 1486 (lipiec 2009): Odzież ochronna dla strażaków. Metody badania i wymagania dla odzieży odbijajacej promieniowanie cieplne przeznaczonej do specjalnej akcji przeciwpożarowej. W normie tej stosowany jest m.in. wskaźnik RHTI - współczynnik przenoszenia promieniowania cieplnego. Zgodnie z tą normą zestaw komponentów odzieży podczas badania prowadzonego zgodnie z EN ISO 6942, przy oddziaływaniu strumienia ciepła o gęstości $40 \mathrm{~kW} / \mathrm{m}^{2}$, powinien wykazać wartość RHTI $24 \geq 120$. Podczas badania zgodnie z PN-EN ISO 367 zestaw komponentów powinien wykazać wartość HTI $24 \geq 21$. Natomiast dla zestawu komponentów badanych zgodnie z EN $702^{2}$, w kontakcie $\mathrm{z}$ ciałem o temperaturze $300^{\circ} \mathrm{C}$, czas progowy powinien być $\geq 15 \mathrm{~s}$.

- Polska Norma PN-EN 15614 (lipiec 2009): Odzież ochronna dla strażaków. Metody badań laboratoryjnych oraz wymagania dla odzieży ochronnej używanej przy pożarach $w$ przestrzeni otwartej. Norma podaje, iż podczas badania zgodnie z EN ISO 6942:2002, metoda B, przy oddziaływaniu strumienia ciepła o gęstości $20 \mathrm{~kW} / \mathrm{m}^{2}$, warstwa pojedyncza, zestaw komponentów lub wielowarstwowy zestaw odzieżowy powinien spełniać następujące warunki: RHTI $24 \geq 11$ oraz RHTI 24 - RHTI $12 \geq 4$.

- Norma amerykańska NFPA 1971: Standard on Protective Ensembles for Structural Fire Fighting and Proximity Fire Fighting. Norma ta opisuje wszechstronne badania ochron osobistych. Wskazuje m.in. metodę opisaną

2 PN-EN 702: Odzież ochronna. Ochrona przed goracem i płomieniem. Metoda badania: Wyznaczanie przenikania ciepła kontaktowego przez odzież ochronna lub materiały na nia przeznaczone (marzec 2002). 
w normie ASTM F-1060 (Standard Test Method for Thermal Protective Performance of Materials for Protective Clothing for Hot Surface Contact) $\mathrm{w}$ odniesieniu do badań ochron w kontakcie z ciałami o podwyższonej temperaturze. Przebieg zmiany temperatury kalorymetru miedzianego jest podstawą do wyliczenia zaabsorbowanej energii i określenia możliwości wystąpienia oparzenia II stopnia. Wskaźnik TPP (Thermal Protective Performance) jest wyznaczany na stanowisku, gdzie próbki ochron są poddawane działaniu strumienia ciepła o gęstości $84 \mathrm{~W} / \mathrm{m}^{2}$, w połowie pochodzącemu z palnika gazowego i w połowie z promiennika kwarcowego. Ilość ciepła przekazywana przez badaną próbkę jest mierzona za pomocą kalorymetru miedzianego, a ryzyko wystąpienia oparzenia II stopnia wyznaczane na podstawie krzywej Stolli.

- Norma amerykańska ASTM F2731: Standard Test Method for Measuring the Transmitted and Stored Energy of Firefighter Protective Clothing Systems. Norma opisuje procedurę badań próbek suchych lub nawilżonych. Próbka poddawana jest działaniu radiacyjnego strumienia ciepła o gęstości $8,5 \pm 0,5 \mathrm{~W} / \mathrm{m}^{2} \mathrm{w}$ ciągu 60, 90 lub $120 \mathrm{~s}$. Następnie sensor dociskany jest do próbki, wywierając nacisk 13,8 kPa, przez $60 \mathrm{~s}$. Na podstawie zarejestrowanej w sensorze zmiany temperatury wyliczana jest całka Henriquesa i czas wystąpienia oparzenia II stopnia dla podanego w normie modelu fizycznego skóry oraz warunków początkowych i brzegowych.

\section{Problemy związane ze stosowanymi metodami pomiarowymi i propozycje ich modyfikacji}

Wnikliwa analiza polskich i amerykańskich norm dotyczących badań odzieży ochronnej i publikacji z nimi związanych pozwala na sformułowanie szeregu uwag dotyczących stosowanych metod i procedur pomiarowych.

- Metody badawcze

Badania odzieży ochronnej zgodnie z polskimi normami wykonuje się w obecności płomienia, źródła promieniowania cieplnego i w kontakcie z ciałem o podwyższonej temperaturze. Jedynie norma amerykańska ASTM F2731 przewiduje badanie próbek (suchych i nawilżonych) pod kątem zmagazynowanego w nich ciepła podczas określonego czasu działania źródła ciepła.

- Kryterium oceny ryzyka oparzenia

Rezultatem polskich badań normowych są wskaźniki wyznaczane na podstawie zaabsorbowanej przez kalorymetr miedziany energii, które pozwalają porównać i uszeregować odzież ochronną, ale nie wskazują rzeczywistego czasu ochrony przed poparzeniem. Większość norm amerykańskich wykorzystuje krzywą Stolli (ryc. 1) jako kryterium wystąpienia oparzenia II stopnia. W praktyce pomiar przyrostu temperatury czujnika TPP (kalorymetru 
miedzianego) w czasie pozwala na określenie efektów działania źródła ciepła (ryc. 2). Należy zwrócić uwagę, że krzywa Stolli została opracowana dla prostokątnego impulsu cieplnego o gęstości strumienia 4,2-16,8 kW/m², działającego na ciało ludzkie. W rzeczywistości gęstość strumienia ciepła przenikającego przez pakiet odzieży ochronnej nie ma takiego charakteru i krzywa Stolli nie odpowiada rzeczywistym warunkom badań. Podobnie nie powinna być wykorzystywana przy dużych gęstościach strumieni ciepła. Ponadto metoda ta pozwala na ocenę ryzyka oparzenia II stopnia, ale nie daje informacji o możliwych poważniejszych uszkodzeniach skóry. Niektóre z norm amerykańskich wskazują na całkę Henriquesa ${ }^{3}$ jako właściwe kryterium oceny skuteczności badanych ochron. Badania porównawcze ${ }^{4}$ wskazują, iż zastosowanie krzywej Stolli daje w wyniku dłuższe czasy ochrony przed oparzeniem niż w przypadku całki Henriquesa lub w ogóle nie wskazuje na ryzyko wystąpienia oparzenia. Wskazane jest zatem wykorzystanie całki Henriquesa jako narzędzia do pełnej oceny skutków działania ciepła na ciało ludzkie.

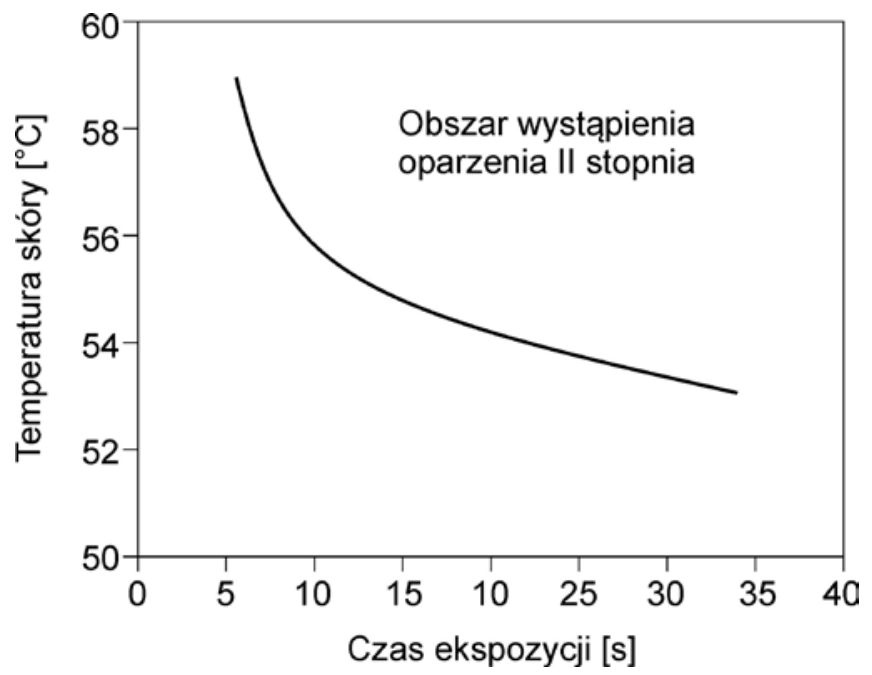

Ryc. 1. Krzywa Stolli

Źródło: A. Stoll, M.A. Chianta, Method and Rating System for Evaluation of Thermal Protection, "Aerospace Medicine", 1969; 40, 1232-8.

3 F.C. Henriques, Jr., Studies of Thermal Injury V. The Predictability and the Significance of Thermally Induced Rate Processes Leading to Irreversible Epidermal Injury, "Archives of Pathology", 1947, 43, 489-502.

4 N.R. Keltner, Evaluating Thermal Protective Performance Testing, "Journal of ASTM International", 5 (May 2005). 


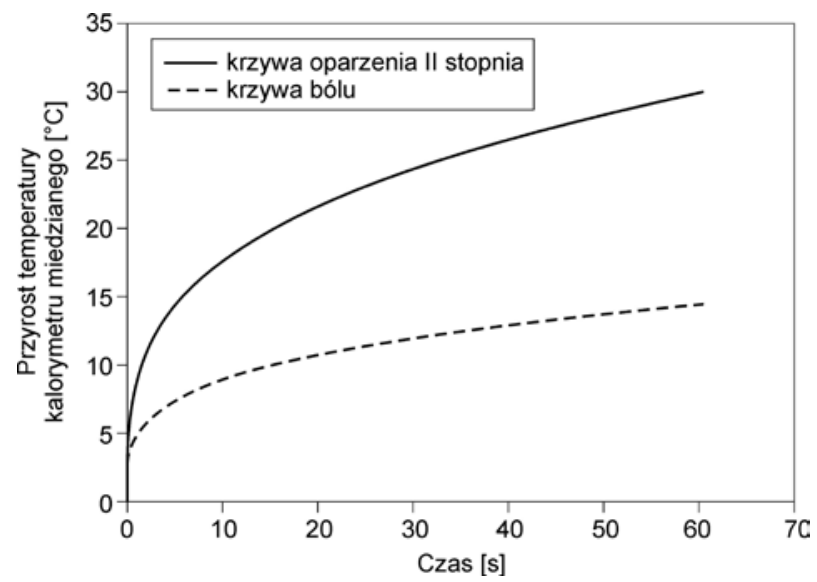

Ryc. 2. Interpretacja przyrostu temperatury czujnika TPP w czasie w oparciu o krzywą Stolli Źródło: G. Song, R. Barker, D.R. Grimes, D. Thompson, Comparison of Methods Used to Predict the Burn Injuries in Tests of Thermal Protective Fabrics "Journal of ASTM International", 2 (February 2005).

- Charakterystyka spektralna źródeł ciepła i wielkość strumienia ciepła Charakterystyki spektralne źródeł ciepła (promienniki podczerwieni, palniki gazowe) różnią się od charakterystyk spektralnych źródeł ognia w rzeczywistych warunkach. Prowadzi to do wyników pomiarów, które mogą odbiegać od warunków rzeczywistych, zwłaszcza przy znacznym zróżnicowaniu spektralnym właściwości radiacyjnych komponentów odzieży ochronnej. Badania normowe wykonywane są dla różnych gęstości strumieni ciepła, m.in. 20, 40 i $80 \mathrm{~kW} / \mathrm{m}^{2}$. Należy pamiętać, że ze względu na znaczny udział radiacyjnej wymiany ciepła nie ma liniowej zależności czasu wystąpienia oparzenia II stopnia od gęstości strumienia ciepła.

- Właściwości sensorów

W przypadku wykorzystania krzywej Stolli do przewidywania oparzenia II stopnia podstawą oceny jest porównanie ilości ciepła zaabsorbowanego przez ciało ludzkie i miedziany kalorymetr. Materiał sensora (kalorymetru) nie jest tu kluczowy, choć wskazana jest duża przewodność cieplna. W przypadku wykorzystania całki Henriquesa do oceny ryzyka oparzenia jest ona obliczana na podstawie przebiegu temperatury na powierzchni sensora. Jego właściwości (dyfuzyjność cieplna i aktywność cieplna) decydują o kształcie tej zależności i wyniku. Konieczne jest dobranie właściwości sensora zbliżonych do ciała ludzkiego (skóry) lub odpowiednie przeliczenie wyników (np. za pomocą metod zagadnień odwrotnych).

- Warunki aklimatyzacji

Według zaleceń podanych w Polskich Normach próbki należy kondycjonować (aklimatyzować) zgodnie z normą EN ISO 1395, czyli wilgotność względna próbek powinna wynosić $(65 \pm 5) \%$, natomiast ich temperatura $(20 \pm 2)^{\circ} \mathrm{C}$. W normach

5 EN ISO 139: Textiles - Standard atmospheres for conditioning and testing (ISO 139:2005). 
amerykańskich warunki aklimatyzacji (np. wg NFPA 1971) to wilgotność względna wynosząca $(65 \pm 5) \%$, a temperatura odpowiednio $(21 \pm 3)^{\circ} \mathrm{C}$. Są to zatem zbliżone warunki. Można jednak rozważać zwiększenie początkowej temperatury do rzeczywistej temperatury odzieży, tj. $25 \div 30^{\circ} \mathrm{C}$.

- Stan badanych ochron osobistych

Badania normowe wykonywane są powszechnie przy użyciu nowych, kondycjonowanych (praktycznie suchych) próbek pakietów odzieży ochronnej. Wskazane jest prowadzenie badań używanej odzieży ochronnej, w tym badań starzenia pod wpływem ciepła. Oczywiście badania te powinny uwzględniać wszystkie właściwości odzieży, w tym termiczne i mechaniczne. Konieczne jest wykonywanie badań odzieży ochronnej zawilgoconej.

\section{Modelowanie transportu ciepła i masy w ochronach osobistych}

Analiza cieplna ubrań ochronnych wymaga rozważania wszystkich podstawowych mechanizmów wymiany ciepła, tj. przewodzenia ciepła (przez warstwy tkanin oraz szczeliny powietrzne), konwekcji (od zewnątrz: bezpośredni kontakt z płomieniem lub powietrzem otaczającym, od wewnątrz: wymuszony ruchem ciała przepływ powietrza) oraz promieniowania cieplnego (emitowanego przez płomień lub gorący obiekt i oddziaływującego z ubraniem ochronnym). Dodatkowo wymianie ciepła towarzyszy ruch wilgoci, która jest obecna w ubraniach ochronnych $\mathrm{z}$ powodu procesów fizjologicznych zachodzących $\mathrm{w}$ organizmie ratownika, jak również przenika $\mathrm{z}$ otoczenia. $\mathrm{W}$ warstwach tkaniny traktowanych jako ośrodki porowate i szczelinach powietrznych dochodzi do konwekcyjnego oraz dyfuzyjnego transportu pary wodnej. Z kolei na skutek procesów kapilarnych woda w postaci ciekłej jest wiązana we włóknach tworzących warstwy tkaniny.

Wszystkie mechanizmy transportu ciepła i masy są ze sobą bezpośrednio lub pośrednio silnie sprzężone, co powoduje, że modelowanie tych zjawisk jest bardzo kłopotliwe i wymaga zaangażowania współczesnych metod numerycznych. Niekiedy konieczne jest wprowadzanie szeregu założeń upraszczających. Dodatkowo kompletne symulatory cieplne powinny również zawierać modele płomienia oraz skóry, aby w prawidłowy sposób przewidzieć zachowanie ubrań ochronnych oraz ocenić stopień zagrożenia oparzeniami.

Opis transportu ciepła i masy w wielowarstwowych ochronach osobistych wymaga podania szeregu właściwości termofizycznych i optycznych dla różnych materiałów wchodzących w skład ubrania ochronnego oraz zdefiniowania efektywnych właściwości cieplnych dla mieszanin powietrzno-parowych oraz ośrodków porowatych (tkaniny). Nie zawsze tego typu dane są dostępne. Wobec ich braku parametry termofizyczne oraz optyczne są przybliżane przy pomocy różnego rodzaju wzorów analitycznych. 


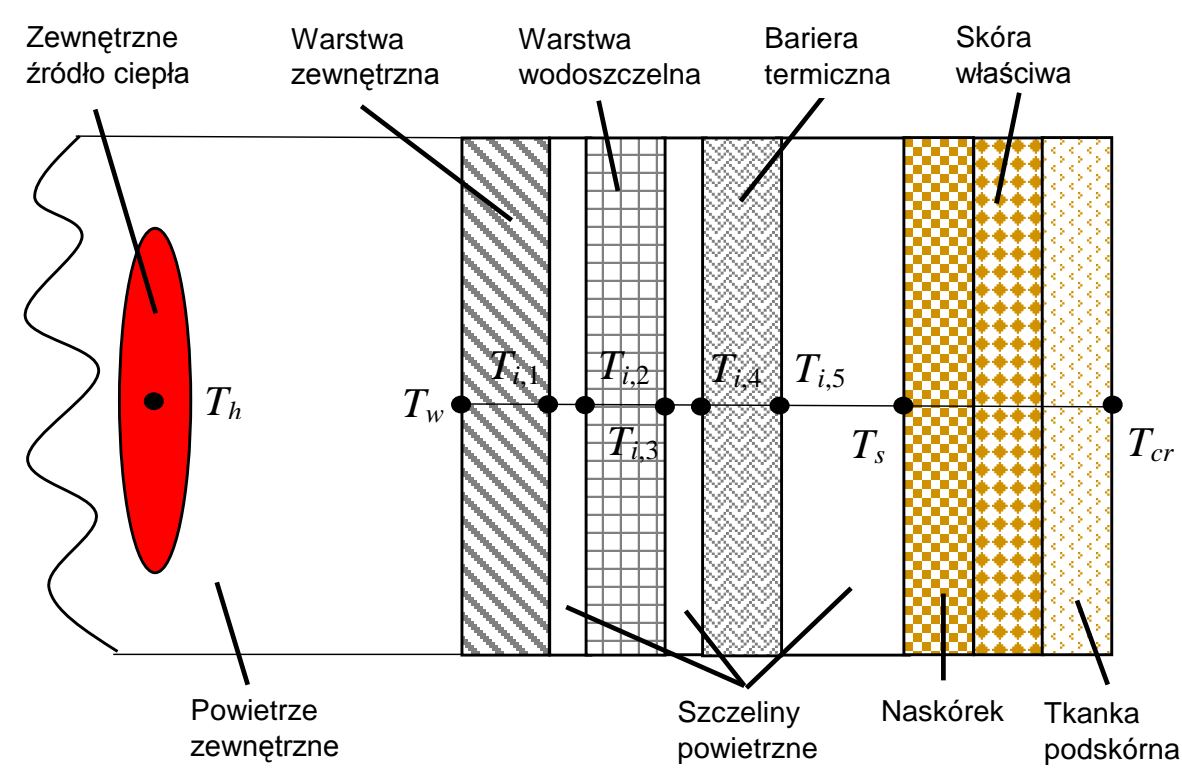

Ryc. 3. Schemat analizowanego układu

Źródło: Opracowanie własne.

\section{Definicja analizowanego układu}

Model cieplny został opracowany dla przykładowego ubioru ochronnego, który jest przedstawione na ryc. 3. Składał się on z trzech warstw tkaniny: warstwy zewnętrznej, warstwy wodoszczelnej oraz bariery termicznej. Pomiędzy porowatymi warstwami tkaniny umieszczono wąskie szczeliny powietrzne. Źródło ciepła było zlokalizowane po stronie lewej, natomiast po prawej znajdowała się duża szczelina powietrzna i trzy warstwy skóry: naskórek, skóra właściwa i tkanka podskórna. W ubiorze ochronnym i skórze rozważano sprzężone przewodzenie ciepła oraz promieniowanie cieplne. Warstwy tkaniny oraz skóry mogły absorbować, emitować (przy podwyższonej temperaturze) oraz rozpraszać promieniowanie cieplne. Założono, że ośrodek może mieć spektralne właściwości optyczne. $Z$ kolei powietrze było traktowane jako medium transparentne. Wilgoć dyfundowała przez warstwy ubioru ochronnego oraz szczeliny powietrzne. Dodatkowo w porowatych warstwach tkanin zachodziły procesy sorpcji i desorpcji. Pominięto konwekcyjny przepływ ciepła i masy przez warstwy ubrania ochronnego i szczeliny powietrzne. $Z$ powodu małej grubości ubioru ochronnego w porównaniu z pozostałymi wymiarami przyjęto jednowymiarowy model transportu ciepła i masy. 


\section{Model transportu ciepła w skórze}

Opracowany model transportu ciepła w skórze to modyfikacja modelu zaproponowanego przez Pennesa ${ }^{6}$. Model ten uwzględniał przewodzenie ciepła, wymianę ciepła pomiędzy przepływającą krwią i tkankami, generację ciepła metabolicznego oraz promieniowanie cieplne ${ }^{7}$. Równania modelowe były następujące:

$$
\begin{aligned}
& (\rho c)_{e p} \frac{\partial T}{\partial t}=\frac{\partial}{\partial x}\left(k_{e p} \frac{\partial T}{\partial x}\right)-\nabla \cdot \mathbf{q}_{r, e p} \\
& (\rho c)_{d} \frac{\partial T}{\partial t}=\frac{\partial}{\partial x}\left(k_{d} \frac{\partial T}{\partial x}\right)+(\rho c)_{b} \omega_{b}\left(T_{c r}-T\right)+q_{m}-\nabla \cdot \mathbf{q}_{r, d} \\
& (\rho c)_{s c} \frac{\partial T}{\partial t}=\frac{\partial}{\partial x}\left(k_{s c} \frac{\partial T}{\partial x}\right)+(\rho c)_{b} \omega_{b}\left(T_{c r}-T\right)+q_{m}-\nabla \cdot \mathbf{q}_{r, s c}
\end{aligned}
$$

gdzie: symbole $e p, d, s c$ oraz $b$ oznaczają odpowiednio: naskórek, skórę właściwą, tkankę podskórną oraz krew. Symbol $\rho$ to gęstość, $c$ to ciepło właściwe, $k$ to przewodność cieplna, $\omega_{b}$ to perfuzja krwi, $q_{m}$ to objętościowa gęstość metabolicznego strumienia ciepła, $T_{c r}=37^{\circ} \mathrm{C}$ to temperatura wnętrza ciała, $\nabla \times \mathbf{q}_{r}$ to dywergencja wektora gęstości radiacyjnego strumienia ciepła. Warunki na brzegach warstw skóry były następujące:

- Na granicach naskórka i skóry właściwej oraz skóry właściwej i tkanki podskórnej (ryc. 3) przyjęto ciągłość temperatury i strumienia ciepła.

- Na prawym brzegu (wnętrze ciała, ryc. 3) przyjęto stałą temperaturę $T_{c r}$.

- Na lewym brzegu (powierzchnia skóry, ryc. 3) temperaturę wyznaczono z poniższego bilansu energii:

$$
\begin{gathered}
-\left.k_{a} \frac{\partial T}{\partial x}\right|_{a}+\int_{0}^{\infty}\left(q_{r, \lambda, i n, a}-\varepsilon_{\lambda, s} E_{b, \lambda}\left(T_{s}\right)-r_{\lambda, s} q_{r, \lambda, i n, a}-\frac{n_{\lambda, a}^{2}}{n_{\lambda, e p}^{2}} t_{\lambda, s} q_{r, \lambda, i n, e p}\right) d \lambda+ \\
-\left.k_{e p} \frac{\partial T}{\partial x}\right|_{s}+\int_{0}^{\infty}\left(q_{r, \lambda, i n, e p}-\varepsilon_{\lambda, s} E_{b, \lambda}\left(T_{s}\right)-r_{\lambda, s} q_{r, \lambda, i n, e p}-\frac{n_{\lambda, e p}^{2}}{n_{\lambda, a}^{2}} t_{\lambda, s} q_{r, \lambda, i n, a}\right) d \lambda=0
\end{gathered}
$$

gdzie: indeksy dolne $s$ i $a$ oznaczają skórę i powietrze, $q_{r, \lambda, \text { in }}$ to monochromatyczna gęstość radiacyjnego strumienia ciepła padająca na powierzchnię, $E_{b, \lambda}$ to monochromatyczne natężenie emisji ciała doskonale czarnego, $\varepsilon, r$ i $t$ oznaczają odpowiednio emisyjność, refleksyjność i transmisyjność powierzchni, $\lambda$ to długość fali promieniowania cieplnego.

6 H.H. Pennes, Analysis of tissue and arterial blood temperatures in the resting human forearm, "Journal of Applied Physiology" 2 (1948), 93-122.

7 A.N. Bashkatov, E.A. Genina, V.V. Tuchin, Optical properties of skin, subcutaneous, and muscle tissue: a review, "Journal of Innovative Optical Health Sciences" 1 (2011), 9-38. 
Do oceny stopnia oparzenia została zastosowana całka Henriquesa ${ }^{8}$. Zgodnie z teorią zaproponowaną przez Henriquesa ${ }^{9}$ oparzenia występują wówczas, gdy temperatura na granicy pomiędzy naskórkiem i skórą właściwą przekracza $T_{e p / d}=44^{\circ} \mathrm{C}$. Wtedy stopień oparzenia można oszacować na podstawie wartości poniższej całki (całka Henriquesa):

$$
\Omega_{i}=\int_{0}^{t} P e^{-\Delta E / B T_{i}} d t \quad \text { dla } \quad T_{e p / d} \geq 44^{\circ} \mathrm{C}
$$

gdzie: $t$ to czas, $P$ to czynnik częstotliwościowy, $B$ to uniwersalna stała gazowa, $\Delta E$ to energia aktywacji dla skóry, $T_{i}$ to temperatura na granicy naskórka i skóry właściwej $(e p / d)$ w przypadku oceny oparzeń I i II stopnia lub na granicy skóry właściwej i tkanki podskórnej $(d / s c)$ w przypadku oceny oparzeń III stopnia. Oparzenia I, II i III stopnia mogą wystąpić, gdy odpowiednio: $\Omega_{e p / d}>0,53, \Omega_{e p / d}>1,0$ i $\Omega_{d / s c}>1,0$.

\section{Model transportu ciepła w tkaninach oraz szczelinach powietrznych}

Równanie energii dla porowatych warstw tkaniny lub szczelin powietrznych, które uwzględniało przewodzenie ciepła, przepływ ciepła związany $\mathrm{z}$ dyfuzją pary wodnej, promieniowanie cieplne oraz ciepło wydzielane lub absorbowane w procesach sorpcji lub desorpcji, było w następującej postaci ${ }^{10}$ :

$$
(\rho c)_{e f} \frac{\partial T}{\partial t}=\frac{\partial}{\partial x}\left(k_{e f} \frac{\partial T}{\partial x}+D_{v-a, e f} \frac{\partial \rho_{v}}{\partial x} c_{p, v} T\right)+\dot{m}_{v b w}\left(\Delta h_{v a p}+\Delta h_{a b s}\right)-\nabla \cdot \mathbf{q}_{r}
$$

Powyższe równanie zostało uzupełnione o następujące zależności domykające:

- Efektywna pojemność cieplna:

$$
(\rho c)_{e f}=\varepsilon_{b w} \rho_{w} c_{w}+\varepsilon_{f} \rho_{f} c_{f}+\varepsilon_{g}\left(\rho_{v} c_{p, v}+\rho_{a} c_{p, a}\right)
$$

gdzie: gęstości suchego gazu oraz pary wodnej wyznaczono z równań:

$$
\begin{aligned}
& \rho_{a}=p_{a} M_{a} / B T=\varepsilon_{a} p M_{a} / B T \\
& \rho_{v}=p_{v} M_{v} / B T=\varepsilon_{v} p M_{v} / B T
\end{aligned}
$$

W powyższych zależnościach $B$ to uniwersalna stała gazowa, $p, p_{a}$ i $p_{v}$ to odpowiednio ciśnienie całkowite, ciśnienie cząstkowe suchego powietrza i ciśnienie cząstkowe pary wodnej, $M_{a}$ i $M_{v}$ to masy cząsteczkowe suchego powietrza i pary wodnej.

8 F.C. Henriques, Jr., Studies of Thermal Injury V. The Predictability and the Significance of Thermally Induced Rate Processes Leading to Irreversible Epidermal Injury, "Archives of Pathology", 1947, 43, 489-502.

9 Tamże.

10 P. Chitrphiromsri, A.V. Kuznetsov, Modeling heat and moisture transport in firefighter protective clothing during flash fire exposure, "Heat and Mass Transfer", 2005, 41, 206-215. 
- Efektywny współczynnik przewodzenia ciepła:

$$
k_{e f}=k_{g}\left\{\left[1+\left(\varepsilon_{b w}+\varepsilon_{f}\right)\right] k_{\sigma}+\varepsilon_{g} k_{g}\right\} /\left\{\varepsilon_{g} k_{\sigma}+\left[1+\left(\varepsilon_{b w}+\varepsilon_{f}\right)\right] k_{g}\right\}
$$

gdzie: współczynniki przewodzenia ciepła powietrza wilgotnego, tkaniny i powietrza suchego dane są zależnościami:

$$
\begin{aligned}
& k_{g}=\left(k_{v} \rho_{v}+k_{a} \rho_{a}\right) /\left(\rho_{v}+\rho_{a}\right) \\
& k_{\sigma}=\left(k_{w} \rho_{w} \varepsilon_{b w}+k_{f} \rho_{f} \varepsilon_{f}\right) /\left(\rho_{w} \varepsilon_{b w}+\rho_{f} \varepsilon_{f}\right) \\
& k_{a}(T)= \begin{cases}0.026+0.000068(T[\mathrm{~K}]-300) & \text { for } T \leq 700 \mathrm{~K} \\
0.053+0.000054(T[\mathrm{~K}]-700) & \text { for } T>700 \mathrm{~K}\end{cases}
\end{aligned}
$$

- Efektywna dyfuzyjność pary wodnej w powietrzu:

$$
D_{v-a, e f}=\left\{\begin{array}{cc}
D_{a} \varepsilon_{g} / \tau & \text { dla tkaniny } \\
D_{a} & \text { dla szczeliny powietrznej }
\end{array}\right.
$$

gdzie: $t$ to krętość. Dyfuzyjność pary wodnej w powietrzu wynosi:

$$
D_{a}=2.23 \cdot 10^{-5}(T / 273.13)^{1.75}
$$

W powyższych równaniach: $\varepsilon_{b w}, \varepsilon_{f}, \varepsilon_{g}, \varepsilon_{a}$ i $\varepsilon_{v}$ to odpowiednio objętościowe udziały wody związanej we włóknach tkaniny, suchej tkaniny, powietrza wilgotnego, powietrza suchego i pary wodnej. Ciepła właściwe oraz współczynniki przewodzenia ciepła dla wody, suchej tkaniny, powietrza suchego i pary wodnej są oznaczone odpowiednio przez symbole $c_{w}, c_{f}, c_{p, a} \mathrm{i} c_{p, v}$ oraz $k_{w}, k_{f}, k_{a} \mathrm{i} k_{v}$. Symbole $\rho_{w}$ i $\rho_{f}$ oznaczają gęstości wody i suchej tkaniny. Ciepło desorpcji wody związanej we włóknach tkaniny do stanu ciekłego oraz ze stanu ciekłego do stanu gazowego były dane następującymi wyrażeniami:

$$
\begin{aligned}
\Delta h_{\text {abs }} & =1.95 \cdot 10^{5}(1-\phi)\left[(0.2+\phi)^{-1}+(1.05-\phi)^{-1}\right] \\
\Delta h_{\text {vap }} & =2.792 \cdot 10^{6}-160 T[\mathrm{~K}]-3.43 T[\mathrm{~K}]^{2}
\end{aligned}
$$

gdzie: wilgotność względna w mieszaninie parowo-powietrznej oraz ciśnienie nasycenia pary wodnej mogą być obliczone ze wzorów:

$$
\begin{aligned}
& \phi=p_{v} / p_{s} \\
& p_{s}=614.3 \exp [17.06(T[\mathrm{~K}]-273.15 / T[\mathrm{~K}]-40.25)]
\end{aligned}
$$

Objętościowy strumień powiązany z przejściem wody związanej we włóknach tkaniny do fazy gazowej dany jest równaniem: 


$$
\dot{m}_{v b w}=D_{f} \rho_{f} / d_{f}^{2}\left(R_{f, e q}-R_{f}\right)
$$

gdzie: stopień nasycenia włókien wodą oraz równowagowy stopień nasycenia włókien wodą dane są zależnościami:

$$
\begin{aligned}
& R_{f}=\varepsilon_{b w} \rho_{w} / \varepsilon_{f} \rho_{f} \\
& R_{f, e q}=0.578 R_{f, \phi=0.65} \phi\left[(0.321+\phi)^{-1}+(1.262-\phi)^{-1}\right]
\end{aligned}
$$

W powyższych równaniach $D_{f}$ to efektywna dyfuzyjność wody związanej w fazie stałej (włóknach tkaniny), $d_{f}$ to średni promień włókien, $R_{f, \phi=0.65}$ to zawartość wilgoci we włóknie przy 65\% wilgotności względnej w otaczającym powietrzu.

Suma wszystkich udziałów objętościowych w porowatych warstwach tkaniny spełnia warunek:

$$
\varepsilon_{b w}+\varepsilon_{f}+\varepsilon_{g}=1
$$

gdzie: $\varepsilon_{g}=\varepsilon_{a}+\varepsilon_{v}$.

W szczelinach powietrznych człony opisujące przemianę fazową wody związanej we włóknach tkaniny w równaniu (6) znikają, a efektywne właściwości są wyznaczane dla powietrza wilgotnego, dla którego zachodzi związek: $\varepsilon_{g}=\varepsilon_{a}+\varepsilon_{v}=1.0$.

$\mathrm{Z}$ prawej strony warunek brzegowy dla równania (6) to temperatura na powierzchni skóry $T_{s}$ (ryc. 3), którą wyznaczono z równania (4). Z kolei po lewej stronie temperaturę powierzchni zewnętrznej ubrania ochronnego $T_{w}$ obliczono z następującego bilansu energii:

$$
\begin{gathered}
-\left.k_{e f} \frac{\partial T}{\partial x}\right|_{w, f}-\left.D_{v-a, e f} \frac{\partial \rho_{v}}{\partial x}\right|_{w, f} c_{p, v} T_{w, f}+q_{a m b} \\
+\int_{0}^{\infty}\left\{q_{r, \lambda, f, i n}-\varepsilon_{\lambda, w} E_{b, \lambda}\left(T_{w}\right)-r_{\lambda, w} q_{r, \lambda, f, i n}-\frac{n_{\lambda, f}^{2}}{n_{\lambda, a m b}^{2}} t_{\lambda, w} q_{r, \lambda, a m b, i n}\right\} d \lambda \\
+\int_{0}^{\infty}\left\{q_{r, \lambda, a m b, i n}-\varepsilon_{\lambda, w} E_{b, \lambda}\left(T_{w}\right)-r_{\lambda, w} q_{r, \lambda, a m b, i n}-\frac{n_{\lambda, a m b}^{2}}{n_{\lambda, f}^{2}} t_{\lambda, w} q_{r, \lambda, f, i n}\right\} d \lambda=0
\end{gathered}
$$

W powyższym równaniu strumień ciepła wymieniany z powietrzem zewnętrznym na drodze konwekcji oraz radiacyjny strumień ciepła padający na powierzchnię zewnętrzną ubioru ochronnego wyrażono następująco:

$$
\begin{aligned}
& q_{a m b}=h_{a m b}\left(T_{a m b}-T_{w}\right)+h_{h}\left(T_{h}-T_{w}\right)+h_{m}\left(\rho_{v, a m b}-\rho_{v, w}\right) c_{p, v} T_{a m b} \\
& q_{r, \lambda, a m b, i n}=\varepsilon_{\lambda, h} E_{b, \lambda}\left(T_{h}\right)+\varepsilon_{\lambda, a m b} E_{b, \lambda}\left(T_{a m b}\right)
\end{aligned}
$$


gdzie: $h_{a m b}$ i $h_{h}$ oraz $T_{a m b}$ i $T_{h}$ to odpowiednio współczynniki przejmowania ciepła oraz temperatury powietrza zewnętrznego i gorących gazów. Symbol $h_{m}$ oznacza współczynnik przejmowania masy, $\varepsilon_{\lambda, a m b}$ i $\varepsilon_{\lambda, h}$ to monochromatyczne emisyjności powietrza zewnętrznego i gorących gazów.

Temperatury $T_{i}$ na granicach (interfejsach) pomiędzy warstwami a szczelinami powietrznymi wyznaczono $\mathrm{z}$ następującego bilansu energii:

$$
\begin{aligned}
&-k_{L}\left.\frac{\partial T}{\partial x}\right|_{i, L}-\left.D_{v-a, e f, L} \frac{\partial \rho_{v}}{\partial x}\right|_{i, L} c_{p, v} T_{i}-\left.k_{R} \frac{\partial T}{\partial x}\right|_{i, R}-\left.D_{v-a, e f, R} \frac{\partial \rho_{v}}{\partial x}\right|_{i, R} c_{p, v} T_{i} \\
&+\int_{0}^{\infty}\left[q_{r, \lambda, L, i n}-\varepsilon_{\lambda, i} E_{b, \lambda}\left(T_{i}\right)-r_{\lambda, i} q_{r, \lambda, L, i n}-\frac{n_{\lambda, L}^{2}}{n_{\lambda, R}^{2}} t_{\lambda, i} q_{r, \lambda, R, i n}\right] d \lambda \\
&+\int_{0}^{\infty}\left[q_{r, \lambda, R, i n}-\varepsilon_{\lambda, i} E_{b, \lambda}\left(T_{i}\right)-r_{\lambda, i} q_{r, \lambda, R, i n}-\frac{n_{\lambda, R}^{2}}{n_{\lambda, L}^{2}} t_{\lambda, i} q_{r, \lambda, L, i n}\right] d \lambda=0
\end{aligned}
$$

gdzie: indeksy dolne $L$ i $R$ oznaczają lewą i prawą stronę interfejsu.

Warunki początkowe dla równania (6) wyznaczono jako równowagowy rozkład temperatury w układzie (ubranie ochronne-skóra), który kontaktuje się tylko z powietrzem zewnętrznym o temperaturze $T_{a m b}$.

\section{Modelowanie transportu masy w warstwach tkaniny oraz w szczelinach powietrznych}

Bilans masowy wody związanej we włóknach tkaniny z uwzględnieniem procesów sorpcji i desorpcji był opisany za pomocą równania ${ }^{11}$ :

$$
\frac{\partial \rho_{w} \varepsilon_{b w}}{\partial t}=\dot{m}_{v b w}
$$

Stężenie objętościowe pary wodnej w powietrzu wypełniającym pory tkaniny oraz szczeliny powietrzne było opisane następującym równaniem, które uwzględniało dyfuzję pary wodnej oraz procesy sorpcji i desorpcji12:

$$
\frac{\partial \rho_{v} \varepsilon_{g}}{\partial t}=\frac{\partial}{\partial x} D_{v-a, e f} \frac{\partial \rho_{v}}{\partial x}-\dot{m}_{v b w}
$$

Warunki brzegowe dla równania (29) były następujące:

- Powierzchnia skóry była nieprzepuszczalna.

- Na lewej ściance (powierzchnia zewnętrzna ubrania ochronnego) gęstość pary wodnej $\rho_{v, w}$ była wyznaczona z poniższego bilansu masy:

$$
h_{m}\left(\rho_{v, a m b}-\rho_{v, w}\right)=-\left.D_{v-a, e f} \frac{\partial \rho_{v}}{\partial x}\right|_{w}
$$

12 Tamże. 
- Na wewnętrznych granicach gęstość pary wodnej $\rho_{v, i}$ obliczono z bilansu masy, który był w postaci:

$$
-\left.D_{v-a, e f, L} \frac{\partial \rho_{v}}{\partial x}\right|_{i, L}=-\left.D_{v-a, e f, R} \frac{\partial \rho_{v}}{\partial x}\right|_{i, R}
$$

Po rozwiązaniu równania (29) udziały objętościowe powietrza suchego oraz pary wodnej otrzymano za pomocą następujących wzorów:

$$
\varepsilon_{a}=\frac{p_{a}}{p} \varepsilon_{g} \quad \text { i } \quad \varepsilon_{v}=\frac{p_{v}}{p} \varepsilon_{g}
$$

gdzie: ciśnienia cząstkowe obliczono z równania stanu gazu doskonałego oraz z prawa Daltona: $p_{v}=r_{v} B T / M_{v}$ i $p_{a}=p-p_{v}$.

Warunek początkowy dla równań (28) i (29) wyznaczono jako równowagowy rozkład udziału objętościowego wody związanej we włóknach tkaniny i udziału objętościowego pary wodnej w powietrzu w układzie (ubranie ochronne-skóra), który kontaktuje się tylko z powietrzem zewnętrznym o temperaturze $T_{a m b}$ i wilgotności względnej $\phi_{a m b}$.

\section{Modelowanie radiacyjnej wymiany ciepła w warstwach tkaniny, szczelinach powietrznych i w skórze}

Rozkład monochromatycznej intensywności promieniowania cieplnego wzdłuż drogi $s$ w układzie gorące gazy-ubranie ochronne-szczelina powietrzna-skóra opisywało poniższe równanie transport promieniowania:

$$
\frac{d I_{\lambda}}{d s}=-\left(K_{a, \lambda}+K_{s, \lambda}\right) I_{\lambda}+K_{a, \lambda} I_{b, \lambda}+\frac{K_{s, \lambda}}{4 \pi} \int_{4 \pi} I_{\lambda} \Phi_{\lambda}\left(\mathbf{s}^{\prime} \rightarrow \mathbf{s}\right) \mathrm{d} \Omega
$$

gdzie: $I_{\lambda}$ to monochromatyczna intensywność promieniowania cieplnego, $I_{b, \lambda}$ to monochromatyczna intensywność emitowana przez ciało doskonale czarne, $K_{a, \lambda}$ i $K_{s, \lambda}$ oznaczają monochromatyczne objętościowe współczynniki absorpcji i rozpraszania, $\Phi_{\lambda}$ to monochromatyczna funkcja fazowa rozpraszania, $\Omega$ to kąt bryłowy. W warstwach tkaniny uwzględniono wszystkie mechanizmy transportu promieniowania cieplnego (absorpcja, rozpraszanie i emisja). Ze względu na niską temperaturę emisja własna promieniowania cieplnego w skórze została pominięta. Powietrze w szczelinach było transparentne. Monochromatyczna intensywność promieniowania ciała doskonale czarnego została wyznaczona z wykorzystaniem prawa Plancka:

$$
I_{b, \lambda}=\frac{1}{\pi} E_{b, \lambda}(T)=\frac{1}{\pi} \frac{2 h c_{0}}{n_{\lambda} \lambda^{5}}\left(e^{h c_{0} / \lambda k T n_{\lambda}}-1\right)^{-1}
$$

gdzie: $c_{0}$ to prędkość światła w próżni, $h$ to stała Plancka, $k$ to stała Boltzmanna, $n_{\lambda}$ to monochromatyczny współczynnik załamania światła. 
Granice pomiędzy ubiorem ochronnym i powietrzem zewnętrznym, warstwami tkaniny oraz szczelinami powietrznymi oraz szczeliną powietrzną i skórą przyjęto jako spektralne półprzeźroczyste (absorbujące, emitujące, odbijające i przepuszczające promieniowanie cieplne) o charakterze dyfuzyjnym. Z kolei granice pomiędzy warstwami skóry były transparentne. Natomiast granicę pomiędzy tkanką podskórną a wnętrzem ciała przyjęto jako doskonale czarną. Warunki na monochromatyczne intensywności promieniowania cieplnego na tych granicach były następujące:

- Ścianka zewnętrzna (powierzchnia zewnętrzna ubioru ochronnego):

$$
I_{\lambda, w}=\varepsilon_{\lambda, w} I_{b, \lambda}\left(T_{w}\right)+r_{\lambda, w} \frac{q_{r, \lambda, f, \text { in }}}{\pi}+t_{\lambda, w} \frac{n_{\lambda, f}^{2}}{n_{\lambda, a m b}^{2}} \frac{q_{r, \lambda, a m b, i n}}{\pi} \text { dla } \quad \mathbf{s} \cdot \mathbf{n}_{w}>0
$$

gdzie: $\mathbf{n}_{w}$ to wektor normalny skierowany do wnętrza ubioru ochronnego.

- Ścianka wewnętrzna pomiędzy warstwami tkaniny i szczelinami powietrznymi:

$$
\begin{aligned}
& I_{\lambda, i, L}=\varepsilon_{\lambda, i} I_{b, \lambda}\left(T_{i}\right)+r_{\lambda, i} \frac{q_{r, \lambda, L, i n}}{\pi}+t_{\lambda, i} \frac{n_{\lambda, L}^{2}}{n_{\lambda, R}^{2}} \frac{q_{r, \lambda, R, i n}}{\pi} \text { dla } \quad \mathbf{s} \cdot \mathbf{n}_{i, L}>0 \\
& I_{\lambda, i, R}=\varepsilon_{\lambda, i} I_{b, \lambda}\left(T_{i}\right)+r_{\lambda, i} \frac{q_{r, \lambda, R, i n}}{\pi}+t_{\lambda, i} \frac{n_{\lambda, R}^{2}}{n_{\lambda, L}^{2}} \frac{q_{r, \lambda, L, i n}}{\pi} \text { dla } \mathbf{s} \cdot \mathbf{n}_{i, R}>0
\end{aligned}
$$

gdzie: $\mathbf{n}_{i, L}$ i $\mathbf{n}_{i, R}$ to wektory normalne na granicy wewnętrznej skierowane w lewą i prawą stronę.

- Ścianka wewnętrzna pomiędzy szczeliną powietrzną a skórą:

$$
\begin{aligned}
& I_{\lambda, i, a}=\varepsilon_{\lambda, s} I_{b, \lambda}\left(T_{s}\right)+r_{\lambda, s} \frac{q_{r, \lambda, a, i n}}{\pi}+t_{\lambda, s} \frac{n_{\lambda, a}^{2}}{n_{\lambda, s}^{2}} \frac{q_{r, \lambda, e p, i n}}{\pi} \text { dla } \mathbf{s} \cdot \mathbf{n}_{i, a}>0 \\
& I_{\lambda, i, e p}=\varepsilon_{\lambda, s} I_{b, \lambda}\left(T_{s}\right)+r_{\lambda, s} \frac{q_{r, \lambda, e p, i n}}{\pi}+t_{\lambda, s} \frac{n_{\lambda, s}^{2}}{n_{\lambda, a}^{2}} \frac{q_{r, \lambda, a, i n}}{\pi} \text { dla } \quad \mathbf{s} \cdot \mathbf{n}_{i, s}>0
\end{aligned}
$$

- Granica pomiędzy tkanką podskórną a wnętrzem ciała:

$$
I_{\lambda, c r}=I_{b, \lambda}\left(T_{c r}\right) \text { dla } \mathbf{s} \cdot \mathbf{n}_{c r}>0
$$

gdzie: $\mathbf{n}_{c r}$ to wektor normalny do brzegu skierowany do wnętrza obszaru obliczeniowego.

Dodatkowe zależności były następujące:

- Monochromatyczna gęstość strumienia ciepła padająca na powierzchnię, która występuje w warunkach na granicach zewnętrznych i wewnętrznych dla równań (6) i (33): 


$$
q_{r, \lambda, i n}=\int_{\mathbf{s} \cdot \mathbf{n}<0} I_{\lambda} \mathbf{s} \cdot \mathbf{n} d \Omega \text { dla } \mathbf{s} \cdot \mathbf{n}<0
$$

- Dywergencja wektora gęstości radiacyjnego strumienia ciepła, która występuje w równaniach (1)-(3) oraz (6):

$$
\nabla \cdot \mathbf{q}_{r}=\frac{\partial q_{r}}{\partial x}=\int_{0}^{\infty} K_{a, \lambda}\left(4 \pi n_{\lambda}^{2} I_{b, \lambda}(T)-\int_{4 \pi} I d \Omega\right) d \lambda
$$

\section{Algorytm obliczeniowy}

Równania (1)-(3), (6), (28) oraz (29) zdyskretyzowano metodą objętości kontrolnych ${ }^{13}$. Nieznane temperatury na granicach wyznaczono $\mathrm{z}$ warunków bilansu energii - równania (4), (24) i (27) - przy pomocy procedury iteracyjnej opartej na metodzie Newtona-Raphsona. Równanie transportu promieniowania (33) zdyskretyzowano również z wykorzystaniem metody objętości kontrolnych dla promieniowania cieplnego ${ }^{14}$. W celu uwzględnienia spektralnych właściwości optycznych zastosowano model pasmowy. Wszystkie równania były sprzężone, dlatego otrzymany układ równań był silnie nieliniowy. Rozwiązanie znaleziono przy pomocy opracowanego autorskiego algorytmu obliczeniowego przedstawionego na ryc. 4 i zaimplementowanego w języku programowania C. Opracowany kod obliczeniowy wczytywał dane wejściowe do obliczeń: warunki brzegowe i początkowe, właściwości termofizyczne i spektralne właściwości optyczne, parametry geometryczne, konfigurację układu warstw tkaniny oraz szczelin powietrznych, poziomy dyskretyzacji z kilku plików zapisanych w formacie ${ }^{*}$.cvs. Obliczenia wykonywane były w pętli iteracyjnej. W pierwszej kolejności wyznaczano temperatury oraz gęstości pary wodnej i powietrza na granicach zewnętrznych i wewnętrznych. Następnie rozwiązywano równanie energii, obliczano udział wody związanej we włóknach oraz gęstości pary i powietrza. Na końcu rozwiązywano równanie transportu promieniowania dla każdego z pasma, wyznaczano całkowite gęstości radiacyjnego strumienia ciepła emitowane, odbijane i przepuszczane na granicach/interfejsach oraz obliczano dywergencję wektora gęstości radiacyjnego strumienia ciepła. Pętla iteracyjna była powtarzana do momentu uzyskania zbieżności wszystkich równań. Po uzyskaniu zbieżności obliczenia były powtarzane dla nowego kroku czasowego.

${ }^{13}$ H.K. Verseeg, W. Malalasekera, An introduction to computational fluid dynamics. The finite volume method, Pearson Education, Harlow 2007.

14 P. Łapka, P. Furmański, Fixed Cartesian grid based numerical model for solidification process of semi-transparent materials I: modelling and verification, "International Journal of Heat and Mass Transfer”, 19-20 (September 2012), 4941-4952; P. Łapka, P. Furmański, Fixed Cartesian grid based numerical model for solidification process of semi-transparent materials II: reflection and refraction or transmission of the thermal radiation at the solid-liquid interface, "International Journal of Heat and Mass Transfer", 19-20 (September 2012), 4953-4964. 


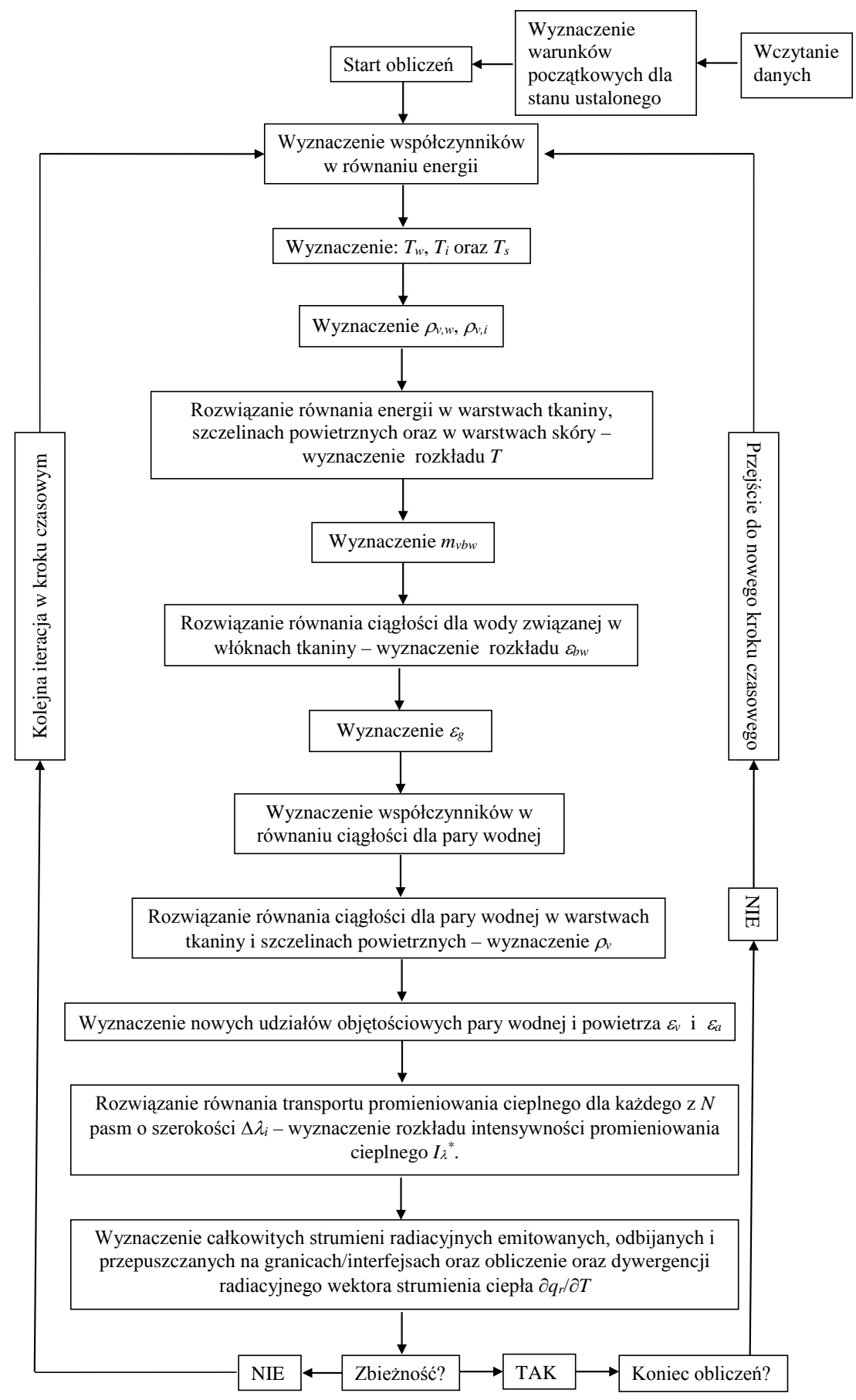

Ryc. 4. Schemat algorytmu obliczeniowego

Źródło: Opracowanie własne. 


\section{Wyniki obliczeń}

Symulacje wykonano dla danych zamieszczonych w tabelach 1-6. Wszystkie wielkości oszacowano na podstawie danych literaturowych ${ }^{15}$. Stałe występujące w całce Henriquesa przyjęto na podstawie danych zawartych w artykule G. Songa, P. Chitrphiromsriego, D. Dinga pt. Numerical simulations of heat and moisture transport in thermal protective clothing under flash fire conditions ${ }^{16}$. Dodatkowo ze względu na brak danych założono, że:

- ośrodki są szare,

- wszystkie warstwy mają taki sam współczynnik załamania światła $n=1$,

- udział rozpraszania wynosi 50\% (albedo $\omega=K_{a} /\left(K_{a}+K_{s}\right)=0,5$ ),

- funkcja fazowa rozpraszania jest izotropowa.

Dla skóry oszacowane średnie właściwości optyczne podane w tabeli 5 przyjęto na podstawie prac ${ }^{17}$. W przypadku skóry określenie właściwości optycznych jest bardzo trudne, ze względu na ich zależność od szeregu czynników anatomicznych i środowiskowych oraz długości fali. W cytowanych pracach nie podano informacji na temat współczynników emisyjności, odbicia i przepuszczenia promieniowania cieplnego powierzchni skóry, dlatego przyjęto je na podstawie oszacowań z wykorzystaniem zależności Fresnela przy założeniu, że 40\% przepuszczonego promieniowania jest absorbowane na powierzchni skóry.

Pozostałe parametry były następujące ${ }^{18}: \rho_{w}=998,2 \mathrm{~kg} / \mathrm{m}^{3}, c_{w}=4185 \mathrm{~J} / \mathrm{kg} / \mathrm{K}$, $k_{w}=0,5984 \mathrm{~W} / \mathrm{m} / \mathrm{K}, k_{v}=0,018 \mathrm{~W} / \mathrm{m} / \mathrm{K}, T_{a m b}=26^{\circ} \mathrm{C}, p=101325 \mathrm{~Pa}-$ stałe w całej warstwie, $\phi_{a m b}=0,68, \varepsilon_{a m b}=1,0, h_{a m b}=10 \mathrm{~W} / \mathrm{m}^{2} / \mathrm{K}, h_{m}=0,021 \mathrm{~m} / \mathrm{s}$. W symulacjach podczas grzania całkowita gęstość radiacyjnego strumienia ciepła dopływająca do powierzchni zewnętrznej ubioru ochronnego wynosiła $q_{\text {total }}=\varepsilon_{\lambda, h} E_{b, \lambda}\left(T_{h}\right)=20$, 40,80 i $160 \mathrm{~kW} / \mathrm{m}^{2}$.

15 P. Chitrphiromsri, A.V. Kuznetsov, Modeling heat and moisture transport in firefighter protective clothing during flash fire exposure, "Heat and Mass Transfer", 2005, 41, 206-215; P. Chitrphiromsri, A.V. Kuznetsov, G. Song, R.L. Barker, Investigation of feasibility of developing intelligent firefighter-protective garments based on the utilization of a water-injection system, "Numerical Heat Transfer Part A", 2006, 49, 427-450.

16 G. Song, P. Chitrphiromsri, D. Ding, Numerical simulations of heat and moisture transport in thermal protective clothing under flash fire conditions, "International Journal of Occupational Safety and Ergonomics" 1 (2008), 89-106.

17 A.N. Bashkatov, E.A. Genina, V.V. Tuchin, Optical properties of skin, subcutaneous, and muscle tissue: a review, "Journal of Innovative Optical Health Sciences" 1 (2011), 9-38; T. Lister, P.A. Wright, P.H. Chappell, Optical properties of human skin, "Journal of Biomedical Optics" 9 (2012), 090901-1-15.

18 P. Chitrphiromsri, A.V. Kuznetsov, Modeling heat and moisture transport in..., dz. cyt.; P. Chitrphiromsri, A.V. Kuznetsov, G. Song, R.L. Barker, Investigation of feasibility of..., dz. cyt. 
Konfiguracja warstw ubioru ochronnego oraz ich grubości

\begin{tabular}{|c|c|c|c|c|c|c|}
\hline $\begin{array}{c}\text { Warstwa } \\
\text { I }\end{array}$ & $\begin{array}{c}\text { Szczelina } \\
\text { I }\end{array}$ & $\begin{array}{c}\text { Warstwa } \\
\text { II }\end{array}$ & $\begin{array}{c}\text { Szczelina } \\
\text { II }\end{array}$ & $\begin{array}{c}\text { Warstwa } \\
\text { III }\end{array}$ & $\begin{array}{c}\text { Szczelina } \\
\text { III }\end{array}$ & \multirow{3}{*}{ Skóra } \\
\cline { 1 - 6 } $0,00056[\mathrm{~m}]$ & $0,0001[\mathrm{~m}]$ & $0,00073[\mathrm{~m}]$ & $0,0001[\mathrm{~m}]$ & $0,00166[\mathrm{~m}]$ & $0,00635[\mathrm{~m}]$ & \\
\hline
\end{tabular}

Źródło: P. Chitrphiromsri, A.V. Kuznetsov, Modeling heat and moisture..., dz. cyt.; P. Chitrphiromsri, A.V. Kuznetsov, G. Song, R.L. Barker, Investigation of feasibility..., dz. cyt.

TABELA 2

Właściwości termofizyczne warstw tkaniny

\begin{tabular}{|l|c|c|c|}
\hline & $\begin{array}{c}\text { Warstwa I: zewnętrzna } \\
\text { (Kombat 7,5 oz/yd }^{2} \text { ) }\end{array}$ & $\begin{array}{c}\text { Warstwa II: bariera } \\
\text { wilgoci (ComfortZone }\end{array}$ & $\begin{array}{c}\text { Warstwa III: bariera } \\
\text { termiczna (Aralite }^{\text {TM }} \text { ) }\end{array}$ \\
\hline$\rho f\left[\mathrm{~kg} / \mathrm{m}^{3}\right]$ & 1384 & 1295 & 1380 \\
\hline$c f[\mathrm{~J} / \mathrm{kg} / \mathrm{K}]$ & 1420 & 1325 & 1200 \\
\hline$k f[\mathrm{~W} / \mathrm{m} / \mathrm{K}]$ & 0,179 & 0,144 & 0,130 \\
\hline$\varepsilon f[-]$ & 0,334 & 0,186 & 0,115 \\
\hline$R_{f, \phi=0.65}$ & 0,084 & 0,038 & 0,045 \\
\hline$\tau$ & 1,50 & 1,25 & 1,00 \\
\hline$D_{f}\left[\mathrm{~m}^{2} / \mathrm{s}\right]$ & $6,0 \times 10^{-14}$ & $6,0 \times 10^{-14}$ & $6,0 \times 10^{-14}$ \\
\hline$d_{f}[\mathrm{~m}]$ & $1,6 \times 10^{-5}$ & $1,6 \times 10^{-5}$ & $1,6 \times 10^{-5}$ \\
\hline
\end{tabular}

Źródło: P. Chitrphiromsri, A.V. Kuznetsov, Modeling heat and moisture..., dz. cyt.; P. Chitrphiromsri, A.V. Kuznetsov, G. Song, R.L. Barker, Investigation offeasibility..., dz. cyt.

TABELA 3

Właściwości termofizyczne warstw skóry oraz krwi

\begin{tabular}{|l|c|c|c|c|}
\hline & Naskórek & Skóra właściwa & Tkanka podskórna & Krew \\
\hline$\rho\left[\mathrm{kg} / \mathrm{m}^{3}\right]$ & 1200 & 1200 & 1000 & 1060 \\
\hline$c[\mathrm{~J} / \mathrm{kg} / \mathrm{K}]$ & 3600 & 3400 & 3060 & 3770 \\
\hline$k[\mathrm{~W} / \mathrm{m} / \mathrm{K}]$ & 0,255 & 0,523 & 0,167 & - \\
\hline$L[\mathrm{~m}]$ & $8 \times 10^{-5}$ & $2 \times 10^{-3}$ & $1 \times 10^{-2}$ & - \\
\hline$q_{m}\left[\mathrm{~W} / \mathrm{m}^{3}\right]$ & 0 & 0 & 0 & \\
\hline$\omega_{b}[1 / \mathrm{s}]$ & - & - & - & $1,25 \times 10^{-3}$ \\
\hline$T_{a}\left[{ }^{\circ} \mathrm{C}\right]$ & - & - & - & 37,0 \\
\hline
\end{tabular}

Źródło: P. Chitrphiromsri, A.V. Kuznetsov, Modeling heat and moisture..., dz. cyt.; P. Chitrphiromsri, A.V. Kuznetsov, G. Song, R.L. Barker, Investigation offeasibility..., dz. cyt. 
TABELA 4

Właściwości optyczne warstw tkaniny i powietrza

\begin{tabular}{|c|c|c|c|c|c|c|c|}
\hline . & $K_{a}[1 / \mathrm{m}]$ & $K_{s}[\mathbf{1} / \mathbf{m}]$ & $n$ & $\Phi[-]$ & $\varepsilon[-]$ & $r[-]$ & $t[-]$ \\
\hline $\begin{array}{l}\text { Warstwa I: } \\
\text { zewnętrzna } \\
\left(\text { Kombat } 7.5 \mathrm{oz} / \mathrm{yd}^{2}\right)\end{array}$ & 4111,8 & 4111,8 & 1,0 & izotropowa & 0,0 & 0,1 & 0,9 \\
\hline $\begin{array}{l}\text { Warstwa II: bariera } \\
\text { wilgoci } \\
\text { (ComfortZone } \\
\text { (CM) }^{2}\end{array}$ & 3154,2 & 3154,2 & 1,0 & izotropowa & 0,0 & 0,1 & 0,9 \\
\hline $\begin{array}{l}\text { Warstwa III: } \\
\text { bariera termiczna } \\
\text { (Aralite } \\
\text { TM }) .\end{array}$ & 1387,1 & 1387,1 & 1,0 & izotropowa & 0,0 & 0,1 & 0,9 \\
\hline Powietrze & 0,0 & 0,0 & 1,0 & izotropowa & - & - & - \\
\hline
\end{tabular}

Źródło: P. Chitrphiromsri, A.V. Kuznetsov, Modeling heat and moisture..., dz. cyt.; P. Chitrphiromsri, A.V. Kuznetsov, G. Song, R.L. Barker, Investigation offeasibility..., dz. cyt.

TABELA 5

Stałe występujące w całce Henriquesa

\begin{tabular}{|l|c|c|c|c|}
\hline \multirow{2}{*}{} & \multicolumn{2}{|c|}{$\boldsymbol{P}\left(\mathbf{s}^{-\mathbf{1}}\right)$} & \multicolumn{2}{c|}{$\Delta \boldsymbol{E}\left(\mathbf{J k m o l}^{\mathbf{- 1}}\right)$} \\
\cline { 2 - 5 } & $\boldsymbol{T}_{\boldsymbol{i}}<\mathbf{5 0}^{\circ} \mathbf{C}$ & $\boldsymbol{T}_{\boldsymbol{i}} \geq \mathbf{5 0}^{\circ} \mathbf{C}$ & $\boldsymbol{T}_{\boldsymbol{i}}<\mathbf{5 0}^{\circ} \mathbf{C}$ & $\boldsymbol{T}_{\boldsymbol{i}} \geq \mathbf{5 0}^{\circ} \mathbf{C}$ \\
\hline Oparzenia I i II stopnia & $2,18 \times 10^{124}$ & $1,82 \times 10^{51}$ & $7,784 \times 10^{8}$ & $3,222 \times 10^{8}$ \\
\hline Oparzenia III stopnia & $4,32 \times 10^{64}$ & $9,39 \times 10^{104}$ & $4,143 \times 10^{8}$ & $6,654 \times 10^{8}$ \\
\hline
\end{tabular}

Źródło: P. Chitrphiromsri, A.V. Kuznetsov, Modeling heat and moisture..., dz. cyt.; P. Chitrphiromsri, A.V. Kuznetsov, G. Song, R.L. Barker, Investigation of feasibility..., dz. cyt.; G. Song, P. Chitrphiromsri, D. Ding, Numerical simulations of heat..., dz. cyt.

TABELA 6

Właściwości optyczne warstw skóry

\begin{tabular}{|l|c|c|c|c|c|c|c|}
\hline & $\boldsymbol{K}_{\boldsymbol{a}}[\mathbf{1} / \mathbf{m}]$ & $\boldsymbol{K}_{\boldsymbol{s}}[\mathbf{1} / \mathbf{m}]$ & $\boldsymbol{n}$ & $\Phi[-]$ & $\varepsilon[-]$ & $\boldsymbol{r}[-]$ & $\boldsymbol{t}[-]$ \\
\hline Naskórek & 200,0 & 2800,0 & 1,36 & izotropowa & 0,20 & 0,50 & 0,30 \\
\hline Skóra właściwa & 700,0 & 2000,0 & 1,36 & izotropowa & - & - & - \\
\hline Tkanka podskórna & 100,0 & 1000,0 & 1,36 & izotropowa & - & - & - \\
\hline
\end{tabular}

Źródło: P. Chitrphiromsri, A.V. Kuznetsov, Modeling heat and moisture..., dz. cyt.; P. Chitrphiromsri, A.V. Kuznetsov, G. Song, R.L. Barker, Investigation of feasibility..., dz. cyt.

Symulacje przeprowadzono w następujący sposób: przez $t_{\text {exp }}$ ubiór ochronny był ogrzewany ze źródła ciepła o całkowitej gęstości strumienia ciepła $q_{\text {total }}$, a następnie chłodzony w otaczającym powietrzu przez $210 \mathrm{~s}$.

Na ryc. 5 przedstawiono rozkłady temperatury w ubraniu ochronnym po czasie równym czasowi ekspozycji $t_{\text {exp }}=60 \mathrm{~s}$ dla różnych gęstości strumienia ciepła. Kolejny wykres (ryc. 6) przedstawia czasowe zmiany temperatury na powierzchni skóry dla czasu eskpozycji $t_{\text {exp }}=60 \mathrm{~s}$ i różnych gęstości strumienia ciepła. Wartości 
całek Henriquesa w zależności od czasu eskpozycji oraz gęstości strumienia ciepła przedstawiono na ryc. 7A oraz 7B odpowiednio na granicy pomiędzy naskórkiem a skórą właściwą (oparzenia I i II stopnia) oraz na granicy skóry właściwej i tkanki podskórnej (oparzenia III stopnia).

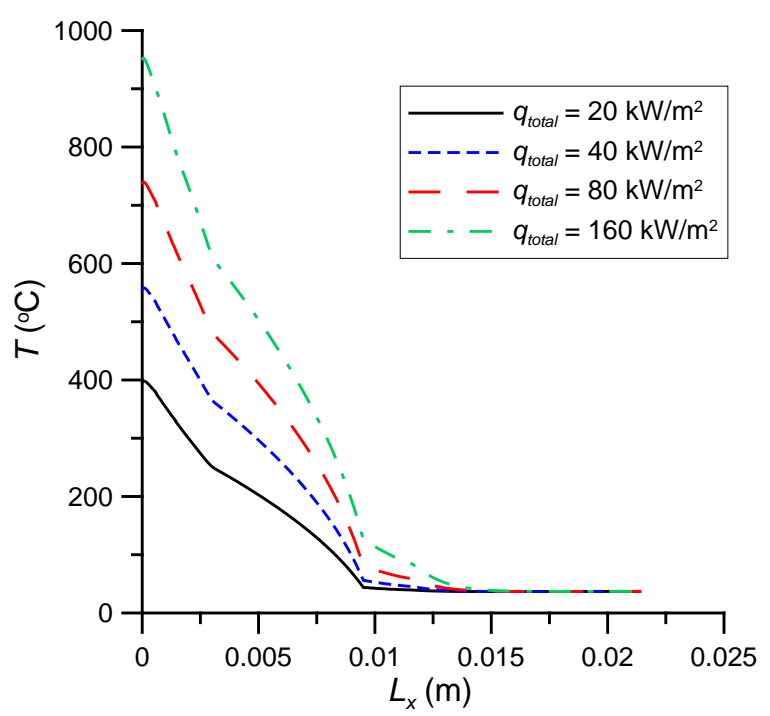

Ryc. 5. Rozkład temperatury w warstwie dla $t_{\text {exp }}=60 \mathrm{~s}$ oraz dla różnych gęstości strumienia ciepła

Źródło: Opracowanie własne.

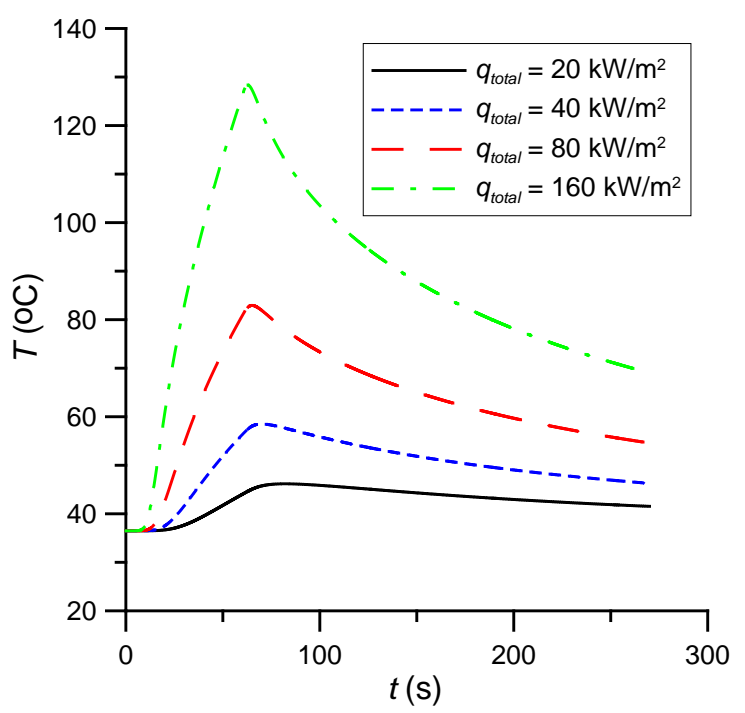

Ryc. 6. Czasowe zmiany temperatury na powierzchni skóry dla $t_{\text {exp }}=60 \mathrm{~s}$ oraz dla różnych gęstości strumienia ciepła

Źródło: Opracowanie własne. 

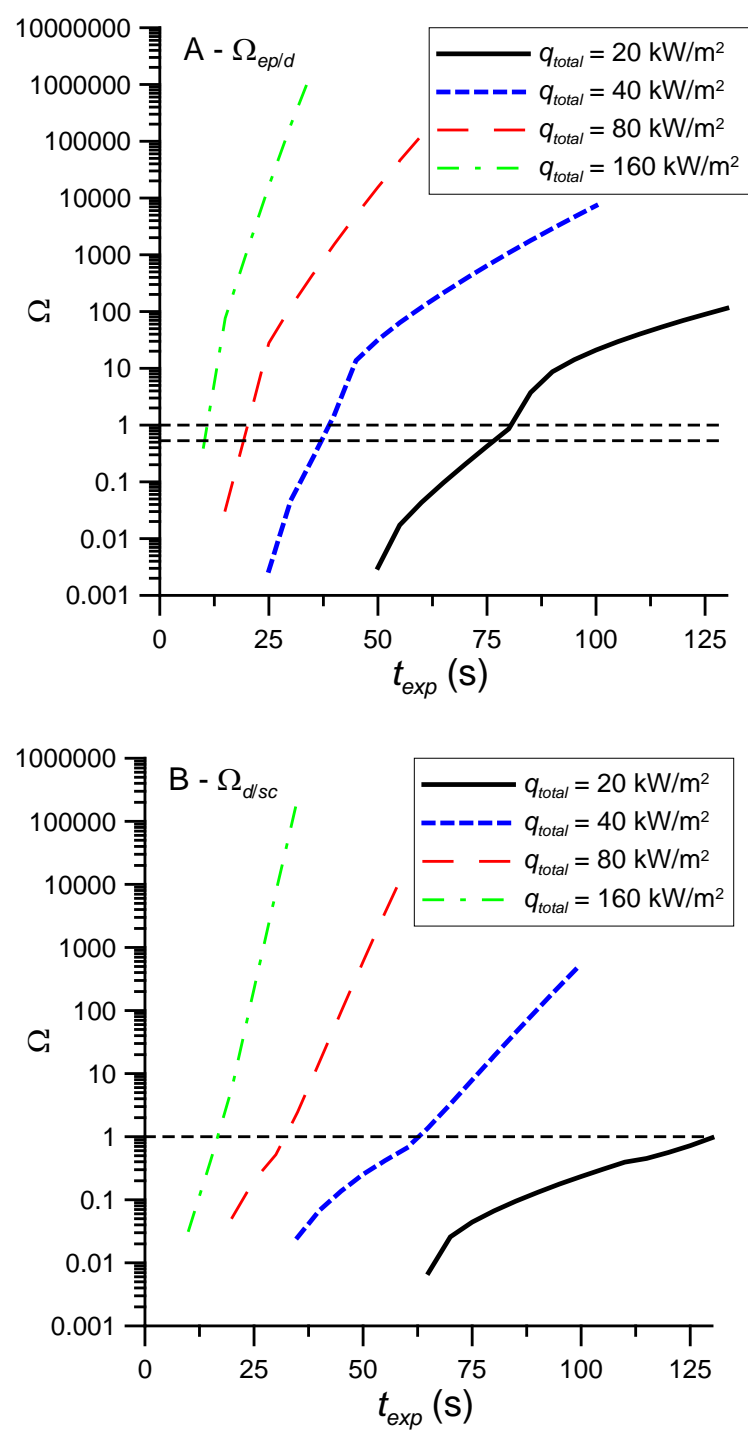

Ryc. 7. Zmiany całki Henriquesa na granicy: A) naskórka i skóry właściwej, B) skóry właściwej i tkanki podskórnej w funkcji czasu ekspozycji - dla różnych gęstości strumienia ciepła Źródło: Opracowanie własne.

\section{Wnioski}

Analiza stosowanych w Polsce i za granicą badań normowych wskazuje, że najwłaściwsze jest zastosowanie całki Henriquesa do oceny odzieży pod względem ochrony przed poparzeniami jako dającej bardziej wiarygodne wyniki i pełniejszą 
informację o skutkach działania strumienia ciepła. Celowa jest modyfikacja sensorów lub przeliczenie wyników odpowiednio do właściwości ciała ludzkiego. Konieczne jest wykonywanie badań dla różnych gęstości strumieni ciepła, zarówno próbek suchych, jak i zawilgoconych. Należy dążyć do stosowania źródeł ciepła o charakterystykach spektralnych możliwie zbliżonych do realnego pożaru. Ponadto do badań normowych należy włączyć pomiary skutków zmagazynowania ciepła w pakietach odzieży ochronnej. Należy rozważyć modyfikację warunków początkowych (warunków aklimatyzacji) dla badanych pakietów odzieży ochronnej. Ze względu na występowanie wszystkich mechanizmów wymiany ciepła oraz obecność wilgoci w postaci gazowej i ciekłej analiza procesów wymiany ciepła i masy w ubraniach ochronnych jest bardzo złożona. Przedstawiony w pracy model matematyczny i numeryczny zawiera szereg równań oraz zależności domykających. Przy jego pomocy wyznaczono rozkłady temperatury w warstwach ubioru ochronnego oraz w skórze, a także wartości całki Henriquesa dla różnych czasów ekspozycji i różnych gęstości strumienia ciepła.

Praca powstała w ramach projektu nr O ROB/0011/03/001 „Opracowanie innowacyjnego systemu stanowisk do badań ochron osobistych". 


\title{
BADANIA ERGONOMICZNE ODZIEŻY OCHRONNEJ Z ZASTOSOWANIEM MANEKINA TYPU NEWTON
}

\author{
Izabella Krucińska \\ Ewa Skrzetuska
}

\section{Wprowadzenie}

Zgodnie z Rozporządzeniem Ministra Pracy i Polityki Socjalnej z dnia 26.09.1997 r. w sprawie ogólnych przepisów bezpieczeństwa i higieny pracy wraz z późniejszymi zmianami Dz. U. z 2011 r. Nr 173, poz. 1034 pracodawca zobowiązany jest do zapewnienia pracownikom w miejscu pracy bezpieczeństwa i higieny pracy. Bezpieczeństwo to w dużym stopniu zależy od stosowanych środków ochrony indywidualnej. Załącznik drugi tego rozporządzenia określa szczegółowe zasady stosowania środków ochrony indywidualnej. W paragrafie drugim tego załącznika czytamy między innymi „Dostarczone pracownikom do stosowania środki ochrony indywidualnej powinny: [...] uwzględniać wymagania ergonomii oraz stan zdrowia pracownika”. Akty prawne wydawane w Polsce i związane z zagadnieniami odnoszącymi się do środków ochrony indywidualnej (ŚOI) muszą być zgodne z Dyrektywą Europejską 89/686/EWG z dnia 21 grudnia 1989 r. w sprawie zbliżenia ustawodawstw Państw Członkowskich odnoszących się do wyposażenia ochrony osobistej. W jednym z zapisów Dyrektywy czytamy, iż środki ochrony indywidualnej powinny spełniać wymagania związane z zapewnieniem komfortu użytkownikowi. To lakoniczne stwierdzenie niesie za sobą potrzebę określenia, co rozumie się pod tym pojęciem. Definicję komfortu znajdujemy w książce pt. Metrologia włókiennicza tom IV, która jest dziełem zbiorowym przygotowanym pod redakcją prof. Wojciecha Szmeltera. Pojęcie komfortu użytkowego odzieży można określić jako „stan przyjemnej fizjologicznej, psychologicznej i fizycznej harmonii między istotą człowieka a otoczeniem". Z tej definicji wynikają trzy składowe komfortu użytkowego odzieży:

- komfort fizjologiczny,

- komfort sensoryczny,

- komfort psychiczny ${ }^{1}$.

Komfort fizjologiczny jest określany właściwościami odzieży, które decydują o zachowaniu równowagi bilansu cieplnego, a więc o regulacji temperatury i transportu wilgoci pomiędzy organizmem człowieka a otoczeniem. Komfort

1 Zob. W. Szmelter (red.), Metrologia włókiennicza, t. IV, WNT, 1972. 
sensoryczny jest związany z mechanicznymi właściwościami wyrobu i opisuje się go za pomocą kompletnego wskaźnika zwanego chwytem. Związany jest on $\mathrm{z}$ pobudzeniem sensorów dotyku rozmieszczonych na naszym ciele $\mathrm{w}$ wyniku zaistnienia kontaktu pomiędzy skórą człowieka a materiałem, z którego wykonano odzież ${ }^{2}$. Komfort psychiczny to niejako wypadkowa komfortu sensorycznego i fizjologicznego, ale też wiąże się on z pojęciem estetyki i gustu użytkownika. Brak poczucia komfortu fizjologicznego i sensorycznego powoduje obniżenie poczucia komfortu psychicznego.

Równanie bilansu cieplnego ujmuje szereg czynników wpływających na zachowanie równowagi cieplnej pomiędzy człowiekiem a otoczeniem, czyli między ciepłem endogennym (powstającym w organizmie w wyniku przemian komórkowych) a ciepłem egzogennym (uzyskiwanym z zewnątrz). Do czynników tych należą:

- wydatek energetyczny związany z intensywnością wykonywanej pracy,

- opór przewodzenia ciepła przez odzież,

- parametry powietrza (temperatura powietrza, średnia temperatura promieniowania, ciśnienie cząstkowe pary wodnej i prędkość powietrza).

Mają one wpływ na ilość ciepła odbieraną z organizmu przez otoczenie w celu zachowania homeotermii (utrzymania temperatury wewnętrznej organizmu na poziomie $\left.37 \pm 0,3^{\circ} \mathrm{C}\right)^{3}$.

Bilans ciepła użytkownika nieokrytego ubiorem w odniesieniu do powierzchni jednostkowej jego ciała można określić następująco.

Ciepło dostarczane $=$ Ciepło tracone;

$M=W+K+C+R+E+C_{\text {res }}+E_{\text {res }}+S$

Wszystkie składniki w głównym równaniu bilansu są wyrażone $\mathrm{w} W \cdot m^{-2}$; $M$ to wydatek metabolizmu, $W$ - efektywna praca mechaniczna, $S$ - nadwyżka ciepła w organizmie; gęstości strumienia utraty ciepła przez $K$ - przewodzenie ciepła z powierzchni skóry, $C$ - konwekcję ciepła z powierzchni skóry, $R$ - promieniowanie ciepła z powierzchni skóry, $E$ - parowanie z powierzchni skóry, $C_{\text {res }}$ - konwekcję w układzie oddechowym, $E_{\text {res }}$ - promieniowanie w układzie oddechowym.

W przypadku, gdy człowiek nosi ubiór, na jego bilans cieplny decydujący wpływ ma izolacyjność cieplna całkowita ubioru traktowanego jako układ zamknięty składający się z warstwy przyskórnej powietrza, materiału, z którego jest wykonany ubiór, i brzegowej warstwy powietrza przylegającej bezpośrednio do zewnętrznej warstwy ubioru.

2 Zob. I. Krucińska, W. Konecki, M. Michalak, Systemy pomiarowe we włókiennictwie, Wyd. Politechniki Łódzkiej, Łódź 2006.

3 Zob. J. Malchaire, A. Piette, B. Kampmann, P. Mehnert, H. Gebhardt, G. Havenith, E. den Hartog, I. Holmer, K. Parsons, G. Alfano, B. Griefahn, Development and validation of the predicted heat strain model, "The Annals of Occupational Hygiene" 2 (2001), 123-135.. 
Odczucie komfortu fizjologicznego jest zagadnieniem skomplikowanym ze względu na mnogość czynników go kształtujących, a także subiektywność odczucia ciepła 4 . Podjęto działania zmierzające do określenia obiektywnych wskaźników związanych z właściwościami biofizycznymi odzieży. Najbardziej kompleksowym rozwiązaniem wydaje się być zastosowanie do oceny komfortu fizjologicznego manekinów termicznych. W Polsce jednym z najnowocześniejszych manekinów termicznych, który służy między innymi do pomiaru komfortu fizjologicznego, dysponuje Katedra Materiałoznawstwa, Towaroznawstwa i Metrologii Włókienniczej na Wydziale Technologii Materiałowych i Wzornictwa Tekstyliów Politechniki Łódzkiej. Manekin ten został wykonany przez Measurement Technology Northwest w Seattle, w Stanach Zjednoczonych i nosi nazwę Newton ${ }^{5}$. Celem pracy było dokonanie oceny wybranych właściwości biofizycznych decydujących o ergonomii odzieży ochronnej dla służb ratowniczych KSRG opracowanej w wyniku realizacji projektu „Nowoczesne ochrony osobiste służb ratowniczych KSRG w oparciu o potrzeby użytkowników końcowych” o akronimie FIREGUARD 2015. Przeprowadzono analizę zmian izolacyjności cieplnej odzieży ochronnej dedykowanej służbom ratowniczym KSRG w różnych warunkach pomiarowych odnoszących się do temperatury, wilgotności i rodzaju noszonej bielizny w zależności od pór roku.

\section{Charakterystyka materiału badawczego}

Do badań zastosowano dwa komplety odzieży ochronnej dla służb ratowniczych KSRG. Wyrób pierwszy to ubranie specjalne do działań ratowniczo-gaśniczych w przestrzeni otwartej. Jest to lekkie ubranie jednowarstwowe zapewniające swobodne wykonywanie czynności przewidzianych podczas akcji gaśniczych w przestrzeni otwartej. Składa się z kurtki i spodni w kolorze ciemnogranatowym. Masa powierzchniowa tkaniny zasadniczej wynosi $230 \pm 10 \% \mathrm{~g} / \mathrm{m}^{2}$, zaś masa kompletnego ubrania wynosi $2,3 \pm 10 \% \mathrm{~kg}$ (ryc. 1). Wyrób drugi jest to ubranie specjalne nowej generacji o maksymalnie ograniczonej masie. Wyrób ten jest dwuczęściowym ubraniem wielowarstwowym w kolorze żółtym, w skład którego wchodzą: kurtka i spodnie. Ubranie składa się z następujących warstw: warstwy zewnętrznej w postaci tkaniny, wkładu wodoszczelno-paroprzepuszczalnego $\mathrm{z}$ warstwą termoizolacyjną oraz z podszewki. Masa powierzchniowa ww. układu materiałów wynosi $450 \pm 10 \% \mathrm{~g} / \mathrm{m}^{2}$, zaś masa kompletnego ubrania wynosi $3,6 \pm 10 \% \mathrm{~kg}$ (ryc. 2).

4 J. Fan, H.W.K. Tsang, Effect of clothing thermal properties on the thermal comfort sensation during active sports, “Textile Research Journal”, 78(2), 2008, 111-118.

5 F. Wang, A Comparative Introduction on Sweating Thermal Manikin "Newton" and "Walter", 7th International Thermal Manikin and Modelling Meeting - University of Coimbra, September 2008; Thermal Manikin Newton, Manual, 2010. 
Jednym z celów pracy było określenie przydatności badanych ubrań do ochrony pracowników przed zimnem, dlatego też zgodnie z normą PN-EN 3422006 Odzież ochronna - Zestawy odzieży i wyroby odzieżowe chroniace przed zimnem dodatkowo do badań zastosowano bieliznę referencyjną w postaci podkoszulka $\mathrm{z}$ długimi rękawami i kalesonów długich charakteryzujących się odpowiednim oporem cieplnym na poziomie $0,060 \pm 10 \% \mathrm{~m}^{2} \mathrm{~K} / \mathrm{W}$ (ryc. 3). Ponadto badania przeprowadzono również z wykorzystaniem bielizny letniej w postaci podkoszulka z krótkimi rękawami i bokserek (ryc. 4).

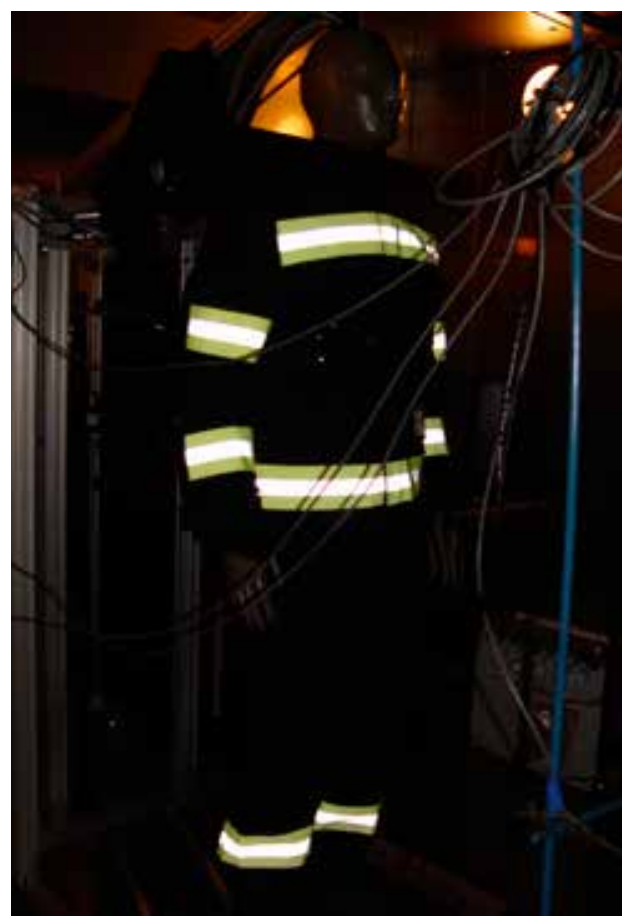

Ryc. 1. Ubranie specjalne do działań ratowniczo-gaśniczych w przestrzeni otwartej

Źródło: I. Krucińska, E. Skrzetuska, Dokumentacja projektowa dotycząca badań ergonomiczności ubrania specjalnego nowej generacji o maksymalnie ograniczonej masie oraz ubrania specjalnego do działań ratowniczo-gaśniczych na przestrzeniach otwartych, niepublikowany, 2014.

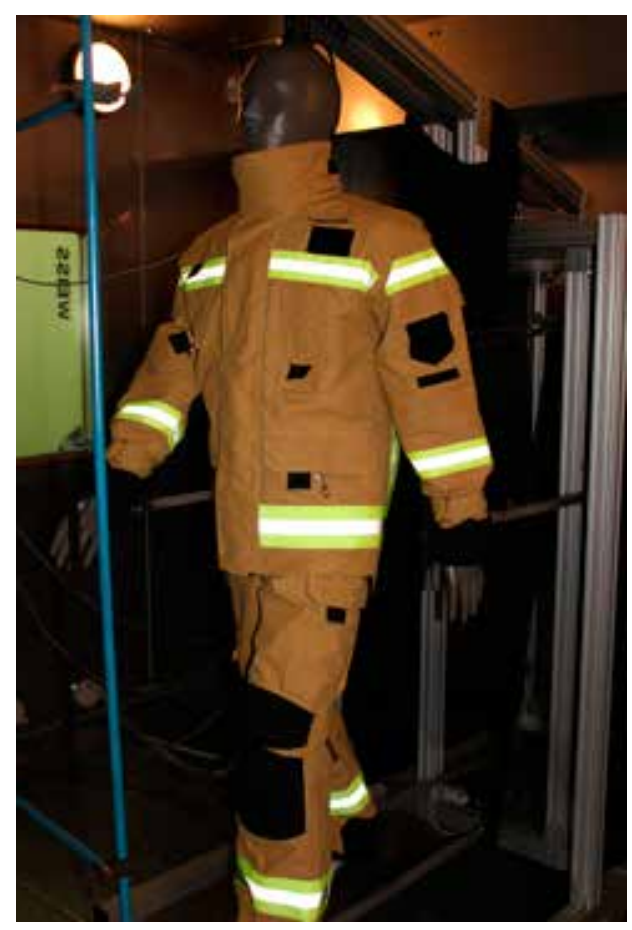

Ryc. 2. Ubranie specjalne nowej generacji o maksymalnie ograniczonej masie Źródło: I. Krucińska, E. Skrzetuska, dz. cyt. 


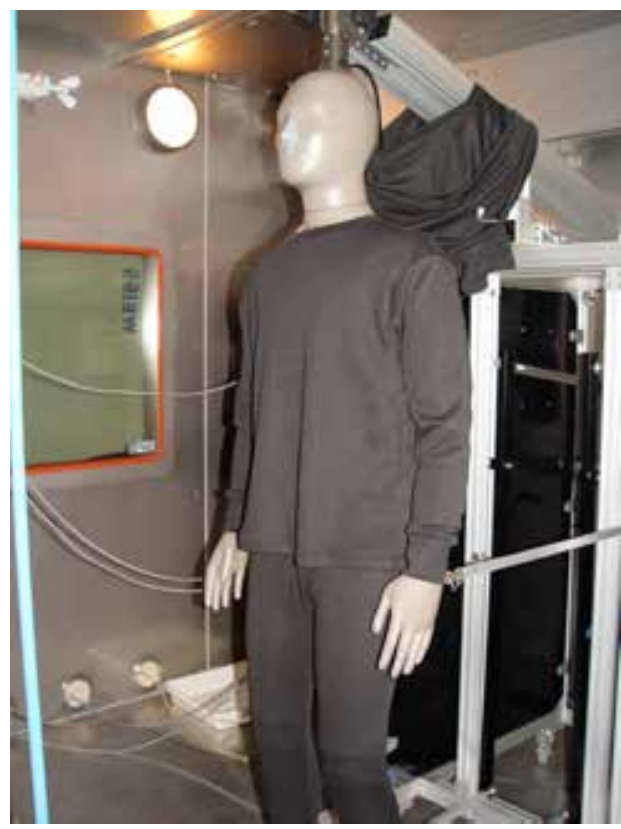

Ryc. 3. Bielizna trudnopalna zimowa składająca się z koszulki z długim rękawem i długich spodni

Źródło: I. Krucińska, E. Skrzetuska, dz. cyt.

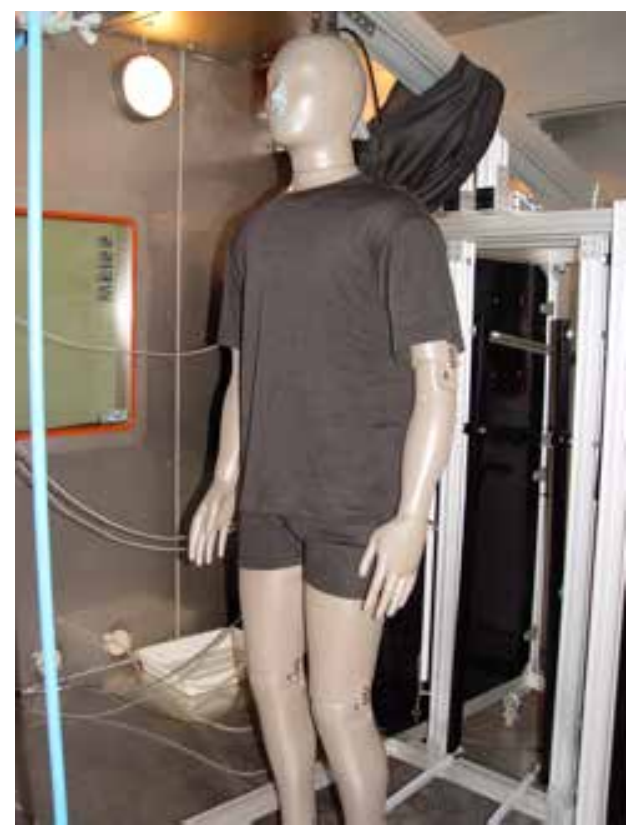

Ryc. 4. Bielizna trudnopalna letnia składająca się z koszulki z krótkim rękawem i krótkich spodenek

Źródło: I. Krucińska, E. Skrzetuska, dz. cyt.

\section{Metodyka badań}

Badania podstawowych właściwości biofizycznych odzieży przeprowadzono zgodnie z normą PN-EN ISO 15831:2006 Odzież - Właściwości fizjologiczne - Pomiar izolacyjności cieplnej z zastosowaniem manekina termicznego. W celu oceny ergonomicznej skuteczności ochronnej w warunkach zimna zastosowano metodykę opisaną w normie PN-EN 342:2006 polegającą na pomiarze izolacyjności cieplnej odzieży razem z bielizną referencyjną. Manekin, którego użyto, posiada ruchome stawy, co umożliwia wyznaczenie wynikowej izolacyjności cieplnej bez konieczności stosowania współczynników korygujących. Jest on manekinem męskim o rozmiarze M i wzroście $170 \mathrm{~cm}$. Sylwetka manekina została wykonana z kompozytu na bazie włókna węglowego wzmocnionego żywicą epoksydową (Carbon Fibre-Epoxy). Sylwetka manekina została podzielona na 34 strefy, z których każda wyposażona jest w niezależny zestaw czujników poboru mocy prądu i regulatorów kontrolujących temperaturę strefy z dokładnością do $+/-0,1^{\circ} \mathrm{C}$. Temperatura powierzchni manekina jest utrzymywana na stałym, założonym poziomie wynoszącym $34^{\circ} \mathrm{C}$, aczkolwiek istnieje możliwość indywidualnego 
ustalenia temperatury dla każdej ze stref tak, aby odzwierciedlały rozkład temperatur dla ciała człowieka. Manekin ma możliwość poruszania się, przy czym regulowana jest liczba kroków w zakresie od 0 do 100 kroków/min (prędkość $4,8 \mathrm{~km} / \mathrm{h}$ ). Manekin posiada funkcję „oddychania”, która pozwala na symulację utraty ciepła w wyniku wymiany gazowej. Liczba wdechów jest regulowana w zakresie 5-20 wdechów/min (bpm), objętość każdego wdechu może mieścić się w zakresie 0,1-2 litrów. Manekin oddycha mieszaniną powietrza i pary wodnej, a temperatura mieszaniny jest równa temperaturze manekina. Manekin posiada opcję „pocenia się”, która polega na doprowadzeniu na powierzchnię manekina wilgoci. Temperatura „potu” jest taka sama jak temperatura powierzchni manekina. Intensywność pocenia się jest regulowana.

W prowadzonych badaniach wyznaczono efektywną izolacyjność cieplną odzieży $I_{c l}$ dla przepływu suchego strumienia ciepła w stanie spoczynku manekina i wynikową efektywną izolacyjność cieplną odzieży $I_{c l r}$ podczas ruchu manekina. W tym celu w pierwszej kolejności na podstawie parametrów dla każdej ze stref wyznaczono wartość całkowitej izolacyjności cieplnej $\mathrm{I}_{\mathrm{ti}}$ ze wzoru:

$$
I_{t i}=\frac{\left(T_{s i}-T_{a}\right)}{H_{c i}}
$$

A następnie obliczono wartość średnią całkowitej izolacyjności cieplnej $I_{t}$ odzieży, stosując model równoległy w oparciu o następujące równanie:

$$
I_{t}=\frac{\left[\left(\sum_{i} f_{i} \times T_{s i}\right)-T_{a}\right] \times A}{\sum_{i} H_{c i}}
$$

gdzie:

$$
f_{i}=\frac{a_{i}}{A}
$$

We wzorach tych $f_{i}$ jest częścią całkowitego pola powierzchni manekina $A$, jaką stanowi pole powierzchni i-tego segmentu $a_{\mathrm{i}}, T_{s i}$ jest temperaturą powierzchni powłoki i-tego segmentu manekina, a $T_{a}$ jest temperaturą powietrza wewnątrz komory klimatycznej. $H_{c i}$ jest mocą grzejną dostarczoną do i-tego segmentu manekina.

W celu wyznaczenia efektywnej izolacyjności cieplnej odzieży należy dodatkowo przeprowadzić badania przy użyciu „nagiego” manekina w spoczynku. Dla takiego pomiaru wyznacza się wartość izolacyjności cieplnej między warstwą otaczającego powietrza a powłoką manekina oznaczoną w normie jako $I_{\mathrm{a}}$, stosując do obliczeń również model równoległy. Efektywną izolacyjność cieplną obliczono ze wzoru przyjmującego postać:

$$
I_{c l}=I_{t}-I_{a}
$$


Wartość $I_{c l r}$ wyznaczono, stosując analogiczne wzory w oparciu o wielkości podstawowe określone dla manekina będącego w ruchu. Celem przeprowadzenia badań manekin został umieszczony w komorze wielkogabarytowej, która umożliwia kontrolę warunków klimatycznych w odniesieniu do: temperatury od $-20^{\circ} \mathrm{C}$ do $+50^{\circ} \mathrm{C}$, wilgotności względnej powietrza w zakresie $10 \%-90 \%$ (dla temperatur punktu rosy od +4 do $+50^{\circ} \mathrm{C}$ ), przepływu powietrza od 0,15 do $1,0 \mathrm{~m} / \mathrm{s}$. Badania prowadzono w warunkach określonych przez normę PN-EN ISO 15831:2006, czyli przy temperaturze każdej strefy wynoszącej $34^{\circ} \mathrm{C} \pm 0,2^{\circ} \mathrm{C}$. Warunki otoczenia dobrano zgodnie z zakresem warunków termicznych, w których najczęściej pracują strażacy na przestrzeniach otwartych. Badania prowadzone były zarówno $\mathrm{w}$ warunkach zimowych $\mathrm{w}$ temperaturze $-20^{\circ} \mathrm{C}$, w warunkach jesienno-wiosennych $\mathrm{w}$ temperaturze $0^{\circ} \mathrm{C}$ oraz w warunkach letnich w temperaturze $+20^{\circ} \mathrm{C}$. $\mathrm{W}$ przypadku prowadzenia badań w warunkach termicznych $+20^{\circ} \mathrm{C}$ możliwe było również utrzymanie wilgotności względnej powietrza na poziomie $50 \%$. W każdym przypadku prędkość przepływającego powietrza wynosiła $0,4 \mathrm{~m} / \mathrm{s}$. Badania prowadzono na manekinie w bezruchu oraz poruszającym się z prędkością 45 kroków/minutę.

\section{Wyniki pomiarów}

W wyniku przeprowadzonych badań wyznaczono następujące wielkości:

- całkowitą izolacyjność cieplną obu zestawów odzieży dla trzech temperatur,

- wynikową całkowitą izolacyjność cieplną obu zestawów odzieży dla trzech temperatur z zastosowaniem poruszającego się manekina,

- całkowitą izolacyjność cieplną granicznej warstwy powietrza, z zastosowaniem nagiego nieruchomego manekina,

- wynikową całkowitą izolacyjność granicznej warstwy powietrza, z zastosowaniem nagiego ruchomego manekina,

- całkowitą izolacyjność cieplną obu zestawów odzieży dla trzech temperatur z udziałem dwóch typów bielizny,

- wynikową całkowitą izolacyjność cieplną obu zestawów odzieży dla trzech temperatur z udziałem dwóch typów bielizny,

- efektywną izolacyjność cieplną obu zestawów odzieży dla trzech temperatur z udziałem dwóch typów bielizny,

- wynikową efektywną izolacyjność cieplną obu zestawów odzieży dla trzech temperatur $z$ udziałem dwóch typów bielizny.

Wyniki pomiarów zestawiono w tabelach 1 i 2 . 
Charakterystyka izolacyjności cieplnej bielizny i nagiego manekina

\begin{tabular}{|l|c|c|c|c|}
\hline \multirow{2}{*}{ Rodzaj obiektu } & $\begin{array}{c}\text { Temperatura otoczenia } \\
\text { / Wilgotność względna } \\
\text { powietrza }\end{array}$ & $\begin{array}{c}\text { Prędkość } \\
\text { powietrza }\end{array}$ & $\begin{array}{c}\text { Całkowita } \\
\text { izolacyjność } \\
\text { cieplna }\end{array}$ & $\begin{array}{c}\text { Wynikowa } \\
\text { calkowita } \\
\text { izolacyjność cieplna }\end{array}$ \\
\cline { 2 - 5 } & ${ }^{\circ} \mathbf{C} / \%$ & $\mathbf{m} / \mathbf{s}$ & $\mathbf{m}^{\mathbf{2}} \cdot \mathbf{K} \cdot \mathbf{W}^{-\mathbf{1}}$ & $\mathbf{m}^{\mathbf{2}} \cdot \mathbf{K} \cdot \mathbf{W}^{-\mathbf{1}}$ \\
\hline \multirow{3}{*}{ Bielizna letnia } & $+20 / 50$ & 0,4 & 0,119 & 0,093 \\
\cline { 2 - 5 } & 0 & 0,4 & 0,114 & 0,092 \\
\hline \multirow{3}{*}{ Bielizna zimowa } & -20 & 0,4 & 0,113 & 0,092 \\
\cline { 2 - 5 } & $+20 / 50$ & 0,4 & 0,161 & 0,157 \\
\hline \multirow{2}{*}{$\begin{array}{l}\text { Graniczna warstwa } \\
\text { powietrza określona } \\
\text { w oparciu o pomiar } \\
\text { gołego manekina }\end{array}$} & 0 & 0,4 & 0,159 & 0,137 \\
\cline { 2 - 5 } & -20 & 0,4 & 0,157 & 0,136 \\
\cline { 2 - 5 } & $+20 / 50$ & 0,4 & 0,087 & 0,071 \\
\hline
\end{tabular}

Źródło: Opracowanie własne

TABELA 2

Wartości izolacyjności cieplnej dla odzieży ochronnej dla służb ratowniczych KSRG, badanej $w$ założonych warunkach klimatycznych

\begin{tabular}{|c|c|c|c|c|c|}
\hline \multirow[t]{2}{*}{$\begin{array}{c}\text { Rodzaj badanego } \\
\text { obiektu }\end{array}$} & $\begin{array}{c}\text { Temperatura } \\
\text { otoczenia / } \\
\text { Wilgotność } \\
\text { względna } \\
\text { powietrza }\end{array}$ & $\begin{array}{c}\text { Efektywna } \\
\text { izolacyjność } \\
\text { cieplna odzie- } \\
\text { ży i bielizny }\end{array}$ & $\begin{array}{c}\text { Efektywna } \\
\text { izolacyjność } \\
\text { cieplna samej } \\
\text { odzieży }\end{array}$ & \begin{tabular}{|c|} 
Wynikowa \\
efektywna \\
izolacyjność \\
cieplna odzie- \\
ży i bielizny \\
\end{tabular} & $\begin{array}{l}\text { Wynikowa } \\
\text { efektywna } \\
\text { izolacyjność } \\
\text { cieplna sa- } \\
\text { mej odzieży }\end{array}$ \\
\hline & ${ }^{\circ} \mathrm{C} / \%$ & $\mathrm{~m}^{2} \cdot \mathrm{K} \cdot \mathrm{W}^{-1}$ & $\mathrm{~m}^{2} \cdot \mathrm{K} \cdot \mathrm{W}^{-1}$ & $\mathrm{~m}^{2} \cdot \mathrm{K} \cdot \mathrm{W}^{-1}$ & $\mathrm{~m}^{2} \cdot \mathrm{K} \cdot \mathrm{W}^{-1}$ \\
\hline \multirow{3}{*}{$\begin{array}{l}\text { Ubranie specjalne no- } \\
\text { wej generacji o max. } \\
\text { ograniczonej masie + } \\
\text { bielizna trudnopalna } \\
\text { letnia }\end{array}$} & $+20 / 50$ & 0,318 & 0,286 & 0,210 & 0,188 \\
\hline & $0 /-$ & 0,289 & 0,257 & 0,194 & 0,174 \\
\hline & $-20 /-$ & 0,254 & 0,234 & 0,192 & 0,170 \\
\hline \multirow{3}{*}{$\begin{array}{l}\text { Ubranie specjalne no- } \\
\text { wej generacji o max. } \\
\text { ograniczonej masie + } \\
\text { bielizna trudnopalna } \\
\text { zimowa }\end{array}$} & $+20 / 50$ & 0,349 & 0,275 & 0,249 & 0,163 \\
\hline & $0 /-$ & 0,322 & 0,245 & 0,225 & 0,160 \\
\hline & -20 & 0,281 & 0,217 & 0,221 & 0,155 \\
\hline \multirow{3}{*}{$\begin{array}{l}\text { Ubranie specjalne do } \\
\text { działań ratowniczo- } \\
\text { gaśniczych w prze- } \\
\text { strzeni otwartej + } \\
\text { bielizna trudnopalna } \\
\text { letnia }\end{array}$} & $+20 / 50$ & 0,191 & 0,159 & 0,144 & 0,122 \\
\hline & 0 & 0,180 & 0,148 & 0,134 & 0,114 \\
\hline & -20 & 0,167 & 0,147 & 0,123 & 0,101 \\
\hline
\end{tabular}




\begin{tabular}{|l|c|c|c|c|c|}
\hline \multirow{2}{*}{$\begin{array}{c}\text { Rodzaj badanego } \\
\text { obiektu }\end{array}$} & $\begin{array}{c}\text { Temperatura } \\
\text { otoczenia / } \\
\text { Wilgotność } \\
\text { względna } \\
\text { powietrza }\end{array}$ & $\begin{array}{c}\text { Efektywna } \\
\text { izolacyjność } \\
\text { cieplna odzie- } \\
\text { ży i bielizny }\end{array}$ & $\begin{array}{c}\text { Efektywna } \\
\text { izolacyjność } \\
\text { cieplna samej } \\
\text { odzieży }\end{array}$ & $\begin{array}{c}\text { Wynikowa } \\
\text { efektywna } \\
\text { izolacyjność } \\
\text { cieplna odzie- } \\
\text { ży i bielizny }\end{array}$ & $\begin{array}{c}\text { Wynikowa } \\
\text { efektywna } \\
\text { izolacyjność } \\
\text { cieplna sa- } \\
\text { mej odzieży }\end{array}$ \\
\cline { 2 - 6 } & ${ }^{\circ} \mathbf{C} / \%$ & $\mathbf{m}^{\mathbf{2}} \cdot \mathbf{K} \cdot \mathbf{W}^{-1}$ & $\mathbf{m}^{\mathbf{2}} \cdot \mathbf{K} \cdot \mathbf{W}^{-1}$ & $\mathbf{m}^{\mathbf{2}} \cdot \mathbf{K} \cdot \mathbf{W}^{-1}$ & $\mathbf{m}^{\mathbf{2}} \cdot \mathbf{K} \cdot \mathbf{W}^{-1}$ \\
\hline $\begin{array}{l}\text { Ubranie specjalne do } \\
\text { działań ratowniczo- } \\
\text { gaśniczych w prze- } \\
\text { strzeni otwartej + } \\
\text { bielizna trudnopalna } \\
\text { zimowa }\end{array}$ & $+20 / 50$ & 0,220 & 0,146 & 0,184 & 0,098 \\
\cline { 2 - 6 } & -20 & 0,180 & 0,116 & 0,155 & 0,091 \\
\hline
\end{tabular}

Źródło: I. Krucińska, E. Skrzetuska, dz. cyt.

\section{Dyskusja nad wynikami}

Przedstawione wyniki badań wskazują, iż pomiar izolacyjności cieplnej jest badaniem złożonym i istotny wpływ na wartości mierzonej wielkości fizycznej ma temperatura i płynąca z niej zmiana wilgotności powietrza oraz postać warstwy między powierzchnią manekina i odzieżą. Właściwości wyrobów włókienniczych zależą od parametrów powietrza, w jakim są prowadzone badania. Wiąże się to zarówno ze zmianą właściwości przewodnictwa samej materii, jak i ze zmianą struktury wyrobu wynikającą ze zmiany parametrów morfologicznych włókien. $Z$ danych zawartych w tabeli 1 i 2 wynika, iż dla wyrobów włókienniczych w każdym badanym wariancie, zarówno dla bielizny, jak i odzieży ochronnej badanej wraz z bielizną, wartości efektywnej izolacyjności cieplnej, jak również wynikowej efektywnej izolacyjności cieplnej zmniejszają się wraz ze spadkiem temperatury otoczenia. Różnice te sięgają nawet wartości rzędu 20\%. Poza tym zauważono, iż wartość efektywnej izolacyjności cieplnej samej odzieży wyznaczona jako różnica pomiędzy całkowitą izolacyjnością cieplną odzieży wraz z bielizną i całkowitą izolacyjnością cieplną bielizny zależy od rodzaju zastosowanej bielizny. We wszystkich badanych przypadkach efektywna izolacyjność cieplna oraz wynikowa efektywna izolacyjność cieplna dla samej odzieży są większe w przypadku badań z użyciem jako referencyjnej bielizny letniej, niż to miało miejsce w przypadku bielizny zimowej. Przeprowadzone pomiary potwierdzają założenie, iż wyznaczana w trakcie pomiaru przy użyciu manekina wartość izolacyjności cieplnej nie odnosi się tylko i wyłącznie do samego wyrobu odzieżowego, ale również do postaci i właściwości warstwy pośredniej między manekinem a odzieżą, mimo uwzględnienia zgodnie z normą izolacyjności cieplnej zmierzonej przy użyciu gołego manekina - który to pomiar przyjęto uważać za charakteryzujący właściwości warstwy pośredniej. Dlatego też wydaje się, iż istnieje dalsza konieczność uszczegółowienia warunków pomiarów izolacyjności cieplnej wyznaczanej przy użyciu normy PN-EN 342:2006. Norma ta nie podaje jednoznacznie temperatury, 
w jakiej należy prowadzić badania celem określenia wynikowej efektywnej izolacyjności cieplnej odzieży w celu określenia jej właściwości ergonomicznych zapewniających utrzymanie komfortu fizjologicznego użytkownika w warunkach pracy (tabele B1 i B2 załącznika B). Zgodnie z normą wytworzona odzież wielowarstwowa nowej generacji o maksymalnie ograniczonej masie posiadająca w swojej strukturze warstwę izolacyjną zabezpiecza użytkownika przed zaburzeniem bilansu cieplnego $\mathrm{w}$ warunkach pracy stojącej o niskim wydatku energetycznym wynoszącym 75W/ $\mathrm{m}^{2}$. Z kolei nie zabezpiecza komfortu fizjologicznego w warunkach ruchu. Zgodnie z normą PN-EN 342:2006 wartość efektywnej izolacyjności cieplnej odzieży wraz $\mathrm{z}$ bielizną referencyjną powinna wynosić przynajmniej $0,310 \mathrm{~m}^{2} \mathrm{~K} \cdot \mathrm{W}^{-1}$. Dla omawianego przypadku wartości te mieszczą się w zakresie $0,318-0,349 \mathrm{~m}^{2} \mathrm{~K} \cdot \mathrm{W}^{-1}$, dla efektywnej izolacyjności cieplnej wyznaczonej w temperaturze $20^{\circ} \mathrm{C}$, przy wilgotności powietrza $50 \%$, prędkości przepływu powietrza $0,4 \mathrm{~m} / \mathrm{s}$.

\section{Wnioski}

Na podstawie otrzymanych wyników można stwierdzić, że na wartość efektywnej izolacyjności cieplnej ma wpływ konstrukcja odzieży. Odzież specjalna nowej generacji o maksymalnie obniżonej masie posiada wkład wodoszczelno-paroprzepuszczający z warstwą termoizolacyjną, dzięki czemu efektywna izolacyjność cieplna jest dużo wyższa niż układu jednowarstwowego zastosowanego w ubraniu specjalnym do działań ratowniczo-gaśniczych. Ubranie to nie spełnia kryteriów zawartych w normie PN-EN 342:2006 i nie może stanowić ochrony przed zimnem. Kryteria takie do pracy stojącej spełnia jedynie ubranie specjalne nowej generacji o maksymalnie ograniczonej masie. Pracownik noszący takie ubranie może pracować, stojąc przez osiem godzin w temperaturze $11^{\circ} \mathrm{C}$ lub 1 godzinę $\mathrm{w}$ temperaturze $-2^{\circ} \mathrm{C}$. Jest on zabezpieczony przed nadmierną utratą ciepła zarówno przy noszeniu bielizny „letniej, jak i „zimowej”.

Analizując wyniki badań, można również zauważyć, że na izolacyjność cieplną ma wpływ rodzaj zastosowanej odzieży spodniej. Zastosowana bielizna zimowa spełnia warunki stawiane odzieży referencyjnej przez normę EN 342:2004. Jednak ze względu na fakt, że strażacy pracują zarówno latem, jak i zimą, należało wykonać badania na bieliźnie letniej i zimowej. Zaobserwowano również, że wraz z obniżaniem temperatury otoczenia obniża się efektywna izolacyjność cieplna obu rodzajów ubrań. 


\title{
BADANIA EKSPLOATACYJNE W POLU OPERACYJNYM
}

\author{
Łukasz Pastuszka \\ Karolina Dwórska \\ Łukasz Rowicki \\ Maciej Gloger
}

\section{Wprowadzenie}

Założeniem projektu rozwojowego nr 0014/R/ID1/2011/01 „Nowoczesne ochrony osobiste służb ratowniczych KSRG w oparciu o potrzeby użytkowników końcowych" finansowanego przez NCBR jest zastosowanie najnowszych osiągnięć technologii tekstylnych umożliwiających spełnienie rosnących wymagań stawianych kompleksowym ochronom osobistym. Założono położenie szczególnego akcentu na wymagania odporności i optymalizowanej skuteczności ochrony przed zagrożeniami podczas działań ratowniczo-gaśniczych przy zachowaniu pełnego komfortu pracy ratownika. $\mathrm{W}$ ramach projektu wypracowano strukturę produktów obejmującą między innymi istotne we współczesnych uwarunkowaniach elementy:

- ubranie strażackie o maksymalnie ograniczonej masie,

- ubranie strażackie do działań ratowniczo-gaśniczych na przestrzeniach otwartych.

$\mathrm{W}$ projekcie stworzono narzędzie umożliwiające $\mathrm{w}$ warunkach rzeczywistych weryfikację ergonomiczności odzieży strażackiej oraz przeprowadzenie badań psychomotorycznych ratowników, którego działanie opiera się na elektronicznym systemie złożonym z jednostki centralnej, przekaźników radiowych oraz tzw. ubrania „inteligentnego" (typu „smart”), wyposażonego w urządzenia elektroniczne umożliwiające zdalne pomiary parametrów środowiskowych oraz fizjologicznych. Ćwiczebny system zintegrowany został opracowany do realizacji funkcji automatycznej: oceny poziomu zmęczenia strażaka (wykrywanie stanu zagrożenia dla zdrowia), analizy wydolności organizmu (test wysiłkowy), lokalizacji strażaka na poligonie i w komorze testowej, analizy parametrów odzieży, oceny komfortu odzieży ochronnej.

Ćwiczebny system niezależny posiada analogiczne funkcje monitorowania parametrów ratowników do systemu zintegrowanego. Różnica polega na umieszczeniu układów pomiarowych w specjalnie zaprojektowanym podkoszulku zamiast w kurtce. Dzięki temu system umożliwia prowadzenie pomiarów parametrów fizjologicznych ratowników wykorzystujących podczas ćwiczeń różne ubrania wierzchnie. Rozwiązanie to pozwala na porównywanie komfortu zapewnianego przez ubrania strażackie 
różnych konstrukcji. System niezależny może być stosowany wraz z dowolnym ubraniem wierzchnim, do którego od zewnątrz dołączony zostanie moduł osobisty.

Uczestnictwo w akcjach ratowniczo-gaśniczych wiąże się ze znacznym ryzykiem zdrowotnym. $Z$ tego powodu, aby wyeliminować niekorzystne warunki pracy strażaków, bardzo istotne staje się zastosowanie innowacyjnych technologii, których przydatność, funkcjonalność i efektywność należy zweryfikować na etapie projektu. Umożliwi to stworzenie i wprowadzenie na rynek krajowy, a następnie międzynarodowy nowoczesnych ochron osobistych przeznaczonych dla służb ratowniczych KSRG o ulepszonych parametrach w stosunku do wyrobów dostępnych na rynku. Nowe modele ubrań ochronnych zapewnią nie tylko lepszą ochronę, ale również podniosą komfort i bezpieczeństwo pracy ratownika.

$\mathrm{W}$ ramach zadań badawczych sformułowanych w projekcie wykonano szereg pomiarów ergonomicznych i eksploatacyjnych ubrań strażackich. Ponieważ rzeczywiste warunki działań ratowniczo-gaśniczych z uwagi na specyfikę są trudne do odtworzenia, zastąpiono je testami w polu operacyjnym w warunkach symulowanych. Przyjęta metodyka zawiera wszystkie elementy proste, które można spotkać przy działaniach w warunkach rzeczywistych, a jednocześnie umożliwia ich wykonanie w warunkach powtarzalnych.

Badaniom w polu operacyjnym poddano dwa produkty projektu:

- ubranie do działań ratowniczo-gaśniczych na przestrzeniach otwartych (ryc. 1),

- ubranie specjalne nowej generacji o maksymalnie ograniczonej masie (ryc. 2).

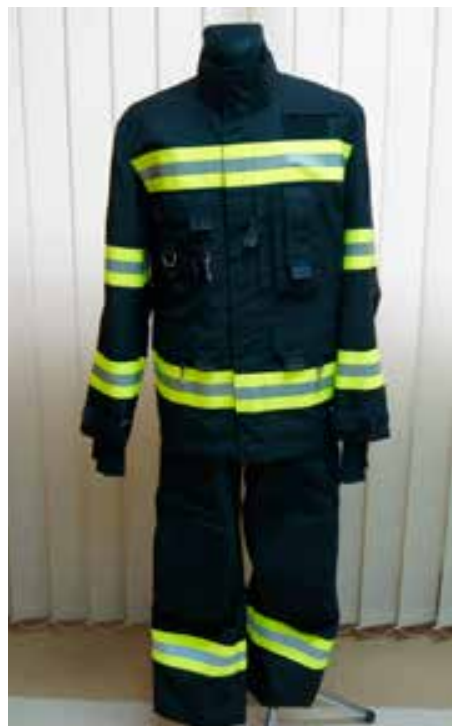

Ryc. 1. Widok ubrania do działań ratowniczo-gaśniczych na przestrzeniach otwartych Źródło: Archiwum CNBOP-PIB.

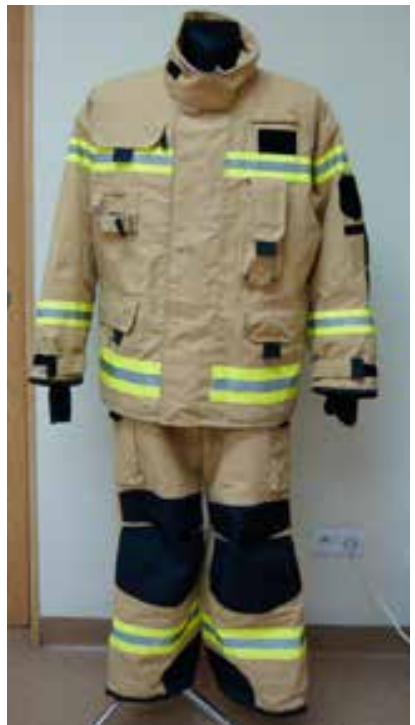

Ryc. 2. Widok ubrania specjalnego nowej generacji o maksymalnie ograniczonej masie Źródło: Archiwum CNBOP-PIB. 
Badania eksploatacyjne zostały wykonane w polu operacyjnym w Kościelcu na poligonie Szkoły Aspirantów Państwowej Straży Pożarnej w Krakowie. Uczestnicy testów byli poddani próbom na poszczególnych stanowiskach. Istotnym elementem realizacji każdego projektu są badania poligonowe demonstratora technologii. Testy poligonowe i w różnego rodzaju komorach czy też stanowiskach ćwiczebnych uzupełnione o badania ankietowe $\mathrm{w}$ pełni pozwalają odzwierciedlić wady i zalety wyrobu oraz dają wskazówki do jego dalszego doskonalenia.

Podczas badań eksploatacyjnych użytkownicy ubrań wykonywali następujące czynności:

- poruszanie się po nierównym terenie o różnych wysokościach,

- pokonywanie strefy zadymionej,

- przenoszenie gruzu,

- pokonywanie strefy cieplnej,

- klękanie na różnorodnym podłożu, np. ostre krawędzie kamieni,

- wykonywanie czynności wymagających użycia siły,

- wykonywanie czynności związanych z obsługą i użyciem narzędzi hydraulicznych,

- przenoszenie elementów pojazdu po odcięciu, posiadających ostre krawędzie o nieregularnych kształtach, np. dach i drzwi samochodu,

- rozwijanie węży pożarniczych,

- wykonywanie czynności, gdzie ruchy nie mogą być krępowane,

- wykonywanie czynności na czas,

- udzielanie pierwszej pomocy.

\section{I etap testów eksperckich}

\section{Stanowisko 1: Komora dymowa}

Wykonujący zadania zostali poddani najpierw próbie wysiłkowej, a następnie przeszli ścieżkę treningową ${ }^{1}$. Przed rozpoczęciem testu dokonano pomiaru ciśnienia krwi i saturacji każdego z uczestników.

Próba wysiłkowa przebiega w następującej kolejności:

- ergometr taśmowy - test trwa 6 minut i polega na przebiegnięciu w tym czasie z prędkością zadaną zależną od wieku uczestnika,

- przerwa - 2 minuty,

- młot podciągowy - ćwiczenie nie dotyczy kobiet - test polega na podciągnięciu i opuszczeniu ciężaru (zadana liczba) w określonym czasie, w zależności od wieku uczestnika,

- przerwa - 2 minuty,

1 Zasady wyposażania i wykorzystania komór dymowych w państwowej straży pożarnej, Komenda Główna Państwowej Straży Pożarnej, Warszawa 2013. 
- ergometr rowerowy - test trwa 1 minutę i polega na jeździe na rowerze stacjonarnym w pozycji siedzącej przy zadanym obciążeniu zależnym od wieku uczestnika,

- jeżeli uczestnik testu znajduje się w przedziale wiekowym powyżej 41 lat, to wykonuje test na tzw. drabinie bez końca - test polega na wchodzeniu po ruchomej drabinie w określonym czasie, w zależności od wieku uczestnika,

W kolejnym etapie testów uczestnicy pokonywali ścieżkę treningową komory dymowej, która podzielona jest na dwie zasadnicze strefy: zadymioną i termiczną.

W czasie przechodzenia przez ścieżkę komory dymowej ćwiczący realizowali następujące zadania:

- pokonywanie różnych poziomów,

- otwieranie przegród pionowych, poziomych i diagonalnych,

- przejście przez zbiornik,

- przechodzenie przez otwory,

- przejście przez odcinki rurowe,

- poruszanie się w pomieszczeniach o różnych wysokościach,

- pokonywanie strefy zadymionej,

- pokonywanie strefy cieplnej,

- wykonywanie innych czynności.

Po przejściu ścieżki dokonywano pomiaru ciśnienia krwi i saturacji.

TABela 1

Zestawienie wyników z użyciem ubrania o ograniczonej masie

Temperatura $w$ górnej części komory $-43,50^{\circ} \mathrm{C}$

Temperatura $w$ dolnej części komory $-16,70^{\circ} \mathrm{C}$

\begin{tabular}{|c|c|c|c|c|c|c|c|}
\hline Ćwiczący & Wiek & $\begin{array}{l}\text { Staż } \\
\text { służby }\end{array}$ & $\begin{array}{c}\text { Ciśnienie / } \\
\text { tętno / } \mathrm{SPO}_{2} \\
\text { przed wejściem }\end{array}$ & $\begin{array}{c}\text { Zużycia } \\
\text { powietrza } \\
\text { [bar] }\end{array}$ & $\begin{array}{c}\text { Ciśnienie / } \\
\text { tętno } / \mathrm{SPO}_{2} \\
\text { po przejściu } \\
\text { komory }\end{array}$ & $\begin{array}{c}\text { Czas } \\
\text { przejścia } \\
{[\mathrm{min}]}\end{array}$ & $\begin{array}{c}\text { Waga/ } \\
\text { wzrost } \\
{[\mathrm{kg} / \mathrm{cm}]}\end{array}$ \\
\hline $\mathrm{Nr} 1$ & 27 & 6 & $\begin{array}{c}140 / 90 \\
77 \\
99\end{array}$ & 140 & $\begin{array}{c}150 / 90 \\
135 \\
98\end{array}$ & 8,51 & $88 / 185$ \\
\hline Nr 2 & 28 & 5 & $\begin{array}{c}115 / 90 \\
82 \\
99\end{array}$ & 140 & $\begin{array}{c}155 / 95 \\
135 \\
98\end{array}$ & 6,25 & $71 / 169$ \\
\hline $\mathrm{Nr} 3$ & 26 & 5 & $\begin{array}{c}120 / 80 \\
54 \\
97 \\
\end{array}$ & 120 & $\begin{array}{c}155 / 95 \\
125 \\
97\end{array}$ & 6,12 & $70 / 179$ \\
\hline $\mathrm{Nr} 4$ & 37 & 13 & $\begin{array}{c}130 / 75 \\
82 \\
99\end{array}$ & 190 & $\begin{array}{c}130 / 85 \\
134 \\
97\end{array}$ & 8,41 & $95 / 186$ \\
\hline
\end{tabular}




\begin{tabular}{|c|c|c|c|c|c|c|c|}
\hline Ćwiczący & Wiek & $\begin{array}{c}\text { Staż } \\
\text { służby }\end{array}$ & $\begin{array}{c}\text { Ciśnienie / } \\
\text { tętno / SP0 } \\
\text { przed wejściem }\end{array}$ & $\begin{array}{c}\text { Zużycia } \\
\text { powietrza } \\
{[\text { bar] }}\end{array}$ & $\begin{array}{c}\text { Ciśnienie / } \\
\text { tętno /SPO } \\
\text { po przejściu } \\
\text { komory }\end{array}$ & $\begin{array}{c}\text { Czas } \\
\text { przejścia } \\
{[\mathbf{m i n}]}\end{array}$ & $\begin{array}{c}\text { Waga/ } \\
\text { wzrost } \\
{[\mathbf{k g} / \mathbf{c m}]}\end{array}$ \\
\hline Nr 5 & 30 & 4 & $\begin{array}{c}135 / 85 \\
59\end{array}$ & 150 & $\begin{array}{c}150 / 90 \\
137\end{array}$ & 9,47 & $82 / 184$ \\
\hline Nr 6 & 30 & 3 & $\begin{array}{c}130 / 80 \\
61\end{array}$ & 130 & $\begin{array}{c}130 / 79 \\
141\end{array}$ & 9,36 & $87 / 187$ \\
\hline
\end{tabular}

Źródło: Opracowanie własne.

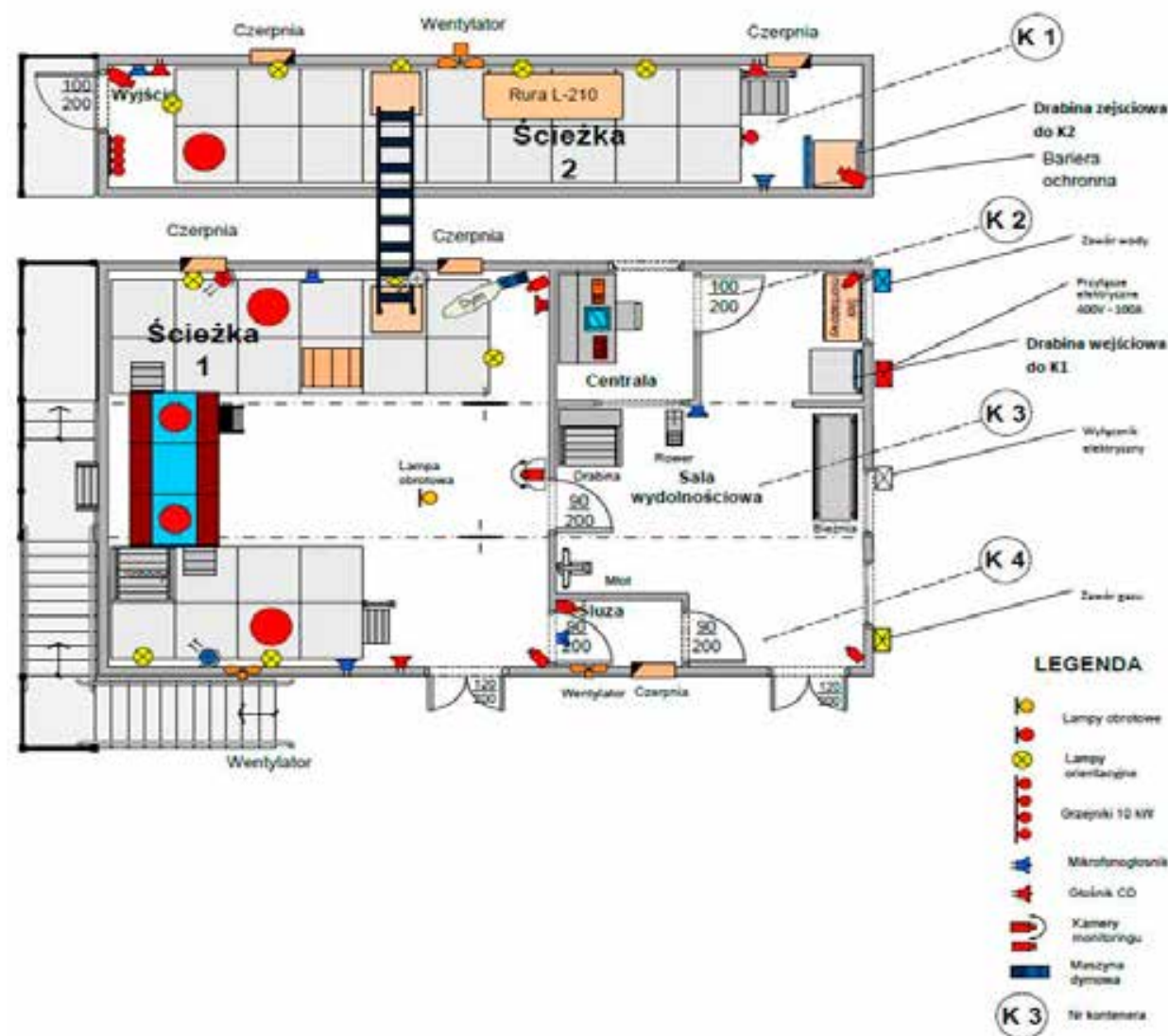

Ryc. 3. Schemat funkcjonalny komory dymowej: a - centrala operatora ścieżki treningowej - sterownia, b - sala wydolnościowa, c - śluza wejścia/wyjścia do/ze ścieżki treningowej, $\mathrm{d}$ - komora dymowa ze strefą zadymioną, e - komora dymowa ze strefą termiczną Źródło: SA PSP Kraków. 
Badanie II po 40 minutach przerwy:

Temperatura w górnej części komory $-45,5^{\circ} \mathrm{C}$

Temperatura w dolnej części komory $-20,8^{\circ} \mathrm{C}$

TABela 2

Zestawienie wyników z użyciem ubrania o ograniczonej masie

- badanie II po 40 minutach przerwy

\begin{tabular}{|c|c|c|c|c|c|c|c|}
\hline Ćwiczący & Wiek & $\begin{array}{c}\text { Staż } \\
\text { służby }\end{array}$ & $\begin{array}{c}\text { Ciśnienie/ } \\
\text { tętno/ } \mathrm{SPO}_{2} \\
\text { przed wejściem }\end{array}$ & $\begin{array}{c}\text { Zużycia } \\
\text { powietrza } \\
\text { [bar] }\end{array}$ & $\begin{array}{c}\text { Ciśnienie/ } \\
\text { tętno/SPO } \\
\text { po przejściu } \\
\text { komory } \\
\end{array}$ & $\begin{array}{c}\text { Czas } \\
\text { przejścia } \\
{[\mathrm{min}]}\end{array}$ & $\begin{array}{c}\text { Waga/ } \\
\text { wzrost } \\
{[\mathrm{kg} / \mathrm{cm}]}\end{array}$ \\
\hline $\mathrm{Nr} 1$ & 27 & 6 & $\begin{array}{c}140 / 85 \\
102 \\
99\end{array}$ & 170 & $\begin{array}{c}125 / 80 \\
112 \\
98\end{array}$ & 7,02 & $88 / 185$ \\
\hline $\mathrm{Nr} 2$ & 28 & 5 & $\begin{array}{c}115 / 70 \\
103 \\
99 \\
\end{array}$ & 100 & $\begin{array}{c}125 / 80 \\
143 \\
98 \\
\end{array}$ & 5,05 & $71 / 169$ \\
\hline Nr 3 & 26 & 5 & $\begin{array}{c}120 / 80 \\
80 \\
98\end{array}$ & 110 & $\begin{array}{c}160 / 90 \\
137 \\
98\end{array}$ & 4,14 & $70 / 179$ \\
\hline $\mathrm{Nr} 4$ & 37 & 13 & $\begin{array}{c}135 / 80 \\
89 \\
98 \\
\end{array}$ & 180 & $\begin{array}{c}130 / 80 \\
109 \\
70 \\
\end{array}$ & 8,53 & $95 / 186$ \\
\hline $\operatorname{Nr} 5$ & 30 & 4 & $\begin{array}{c}135 / 80 \\
78 \\
98 \\
\end{array}$ & 130 & $\begin{array}{c}130 / 79 \\
150 \\
99 \\
\end{array}$ & 8,24 & $82 / 184$ \\
\hline $\mathrm{Nr} 6$ & 30 & 3 & $\begin{array}{c}140 / 85 \\
73 \\
99\end{array}$ & 160 & $\begin{array}{c}150 / 85 \\
108 \\
99\end{array}$ & 10,46 & $87 / 187$ \\
\hline
\end{tabular}

Źródło: Opracowanie własne.

\section{Stanowisko 2: Katastrofy budowlane, gruzowisko}

Etapy testu:

- budowanie zestawu w strefie bezpiecznej, przy czym elementy zestawu to m.in. butla, reduktor, przewody, sterownik i poduszka,

- po złożeniu zestawu poduszkę umieszczono między betonowymi płytami,

- pompowanie poduszki w sposób jednostajny, powolny i precyzyjny, aż do uniesienia się betonowej płyty,

- po podniesieniu płyty przez poduszkę wyjęcie większego gruzu spod płyty (również przy pomocy drewnianych belek),

- wyżej wymienione czynności powtórzono dla mniejszej płyty, stosując mniejszą poduszkę,

- czynności końcowe polegające na zamknięciu zaworu, odłączeniu przewodów od poduszki, spuszczeniu powietrza z poduszki. 


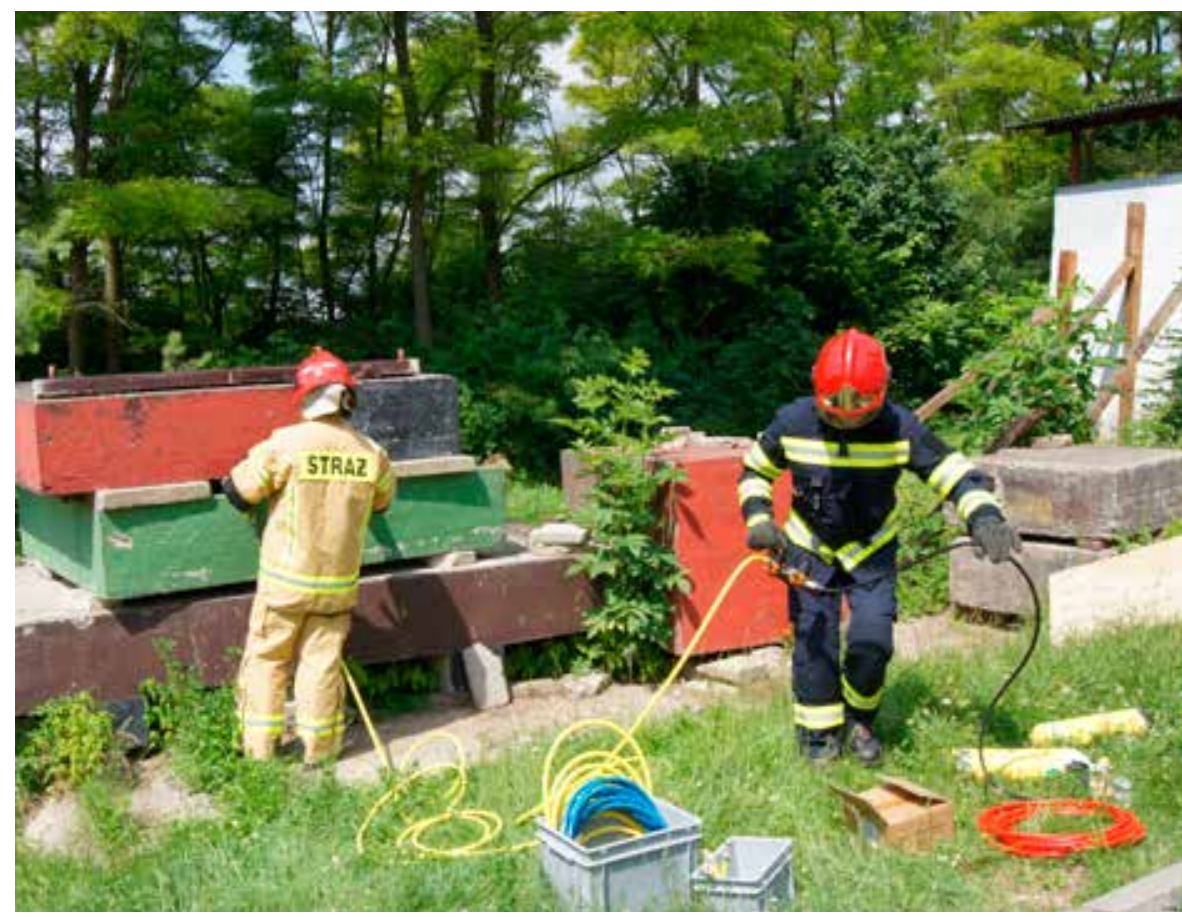

Ryc. 4. Testowanie ubrań podczas działań na stanowisku: Katastrofy budowlane Źródło: Opracowanie własne CNBOP-PIB.

\section{Stanowisko 3: Działania ratowniczo-gaśnicze}

Test składa się z dwóch etapów wykonywanych jednocześnie:

- Etap 1: stabilizacja płyty betonowej przy pomocy ratowniczego zestawu pneumatycznego rozpierającego, wykonanie przebicia za pomocą młota udarowego. W tej części uczestnik zadania testował ubranie do działań ratowniczogaśniczych na przestrzeniach otwartych;

- Etap 2: podanie środków gaśniczych poprzez wykonanie linii ssawnej z motopompy z dwóch odcinków węży ssawnych W110 zakończonej smokiem ssawnym, linia główna z jednego odcinka, linia gaśnicza z dwóch odcinków W75 zakończona prądownicą PW75. Podanie prądu gaśniczego w pozycji stojącej. W tej części uczestnik zadania testował ubranie specjalne nowej generacji o maksymalnie ograniczonej masie. 


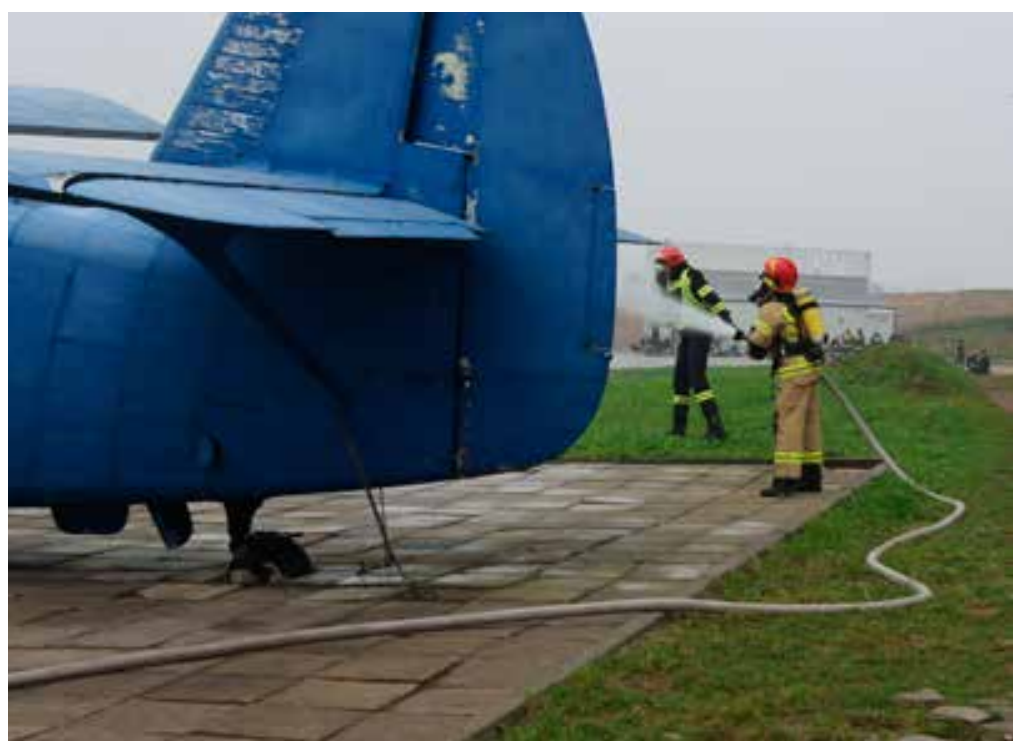

Ryc. 5. Testowanie ubrania podczas działań na stanowisku ratowniczo-gaśniczym Źródło: Opracowanie własne CNBOP-PIB.

\section{Stanowisko 4: Ratownictwo drogowe, cięcie pojazdu}

Zadanie polegało na odcięciu dachu oraz drzwi samochodu osobowego za pomocą narzędzi hydraulicznych. Uczestnicy testujący oba modele ubrań wykonywali główne czynności podczas zadania, obsługiwali narzędzia hydrauliczne, odciągali elementy pojazdu przy użyciu siły, przenosili odcięty dach i drzwi samochodu.

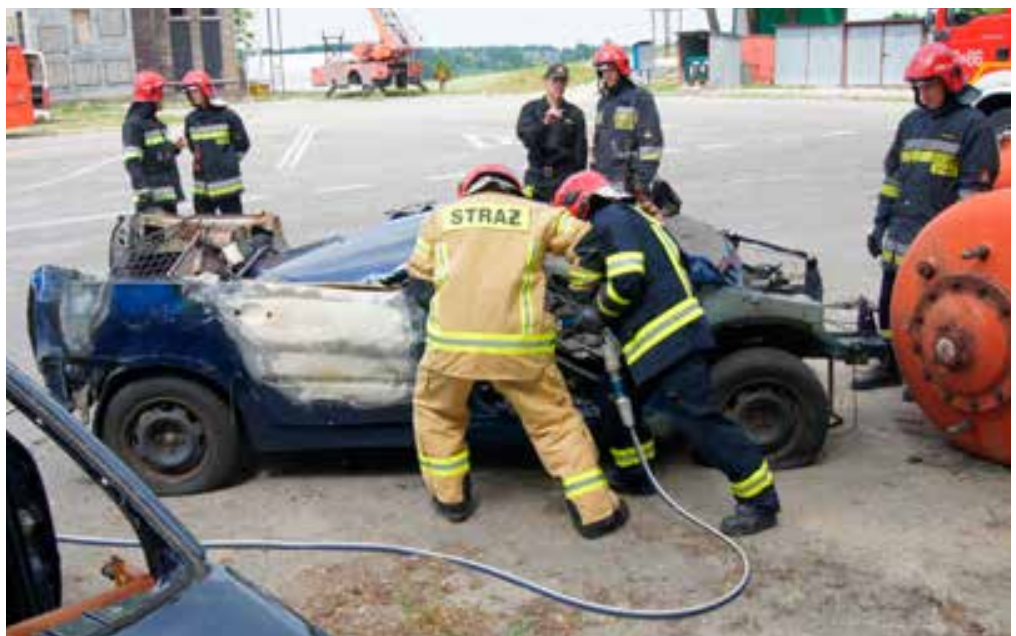

Ryc. 6. Testowanie ubrań podczas działań na stanowisku: Ratownictwo drogowe, cięcie pojazdu Źródło: Opracowanie własne CNBOP-PIB. 


\section{Stanowisko 5: Ratownictwo drogowe, podnoszenie pojazdu}

Test polegał na zbudowaniu zestawu składającego się m.in. z butli, reduktora, przewodów, sterownika i poduszki wysokiego podnoszenia, a następnie umieszczeniu poduszki pod samochodem. Kolejna czynnością było napompowanie poduszki tak, aby podnieść pojazd.

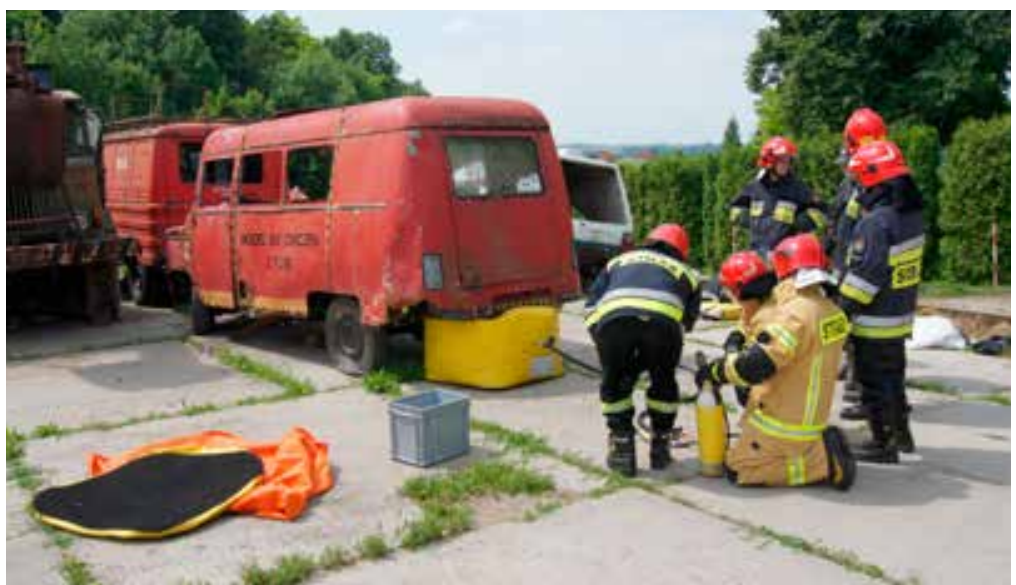

Ryc. 7. Testowanie ubrań podczas działań na stanowisku: Ratownictwo drogowe, podczas podnoszenia pojazdu

Źródło: Opracowanie własne CNBOP-PIB.

\section{Stanowisko 6: Pożar w budynku mieszkalnym}

Przebieg testu zależał od scenariusza akcji ratowniczo-gaśniczej, jednak występowały elementy powtarzające się:

- po uzyskaniu sygnału przyjazd na miejsce zdarzenia jednostek ratowniczogaśniczych,

- rozwinięcie węży pożarniczych, by zbudować linię gaśniczą,

- zabezpieczenie miejsca zdarzenia przez rozstawienie pachołków,

- sprawdzenie drzwi do budynku,

- w zależności od scenariusza akcji:

- otwarcie okna budynku i wejście za pomocą drabiny do środka, wraz ze sprzętem wypełnionym wodą, tzn. wężem pożarniczym zakończonym prądownicą,

- wyniesienie na noszach poszkodowanego znajdującego się przy drzwiach od zewnętrznej strony budynku, udzielenie mu pierwszej pomocy po wyniesieniu go ze strefy,

- otwarcie drzwi budynku i wejście do środka, wraz ze sprzętem wypełnionym wodą tzn. wężem pożarniczym zakończonym prądownicą,

- w zależności od scenariusza akcji:

- wejście do budynku drugiej grupy strażaków z linią gaśniczą, 
- ustawienie wentylatora przy wejściu do budynku (przed otworem),

- wyniesienie poszkodowanego, udzielenie pierwszej pomocy,

- wyjście z budynku, usunięcie gaśniczej linii wężowej.

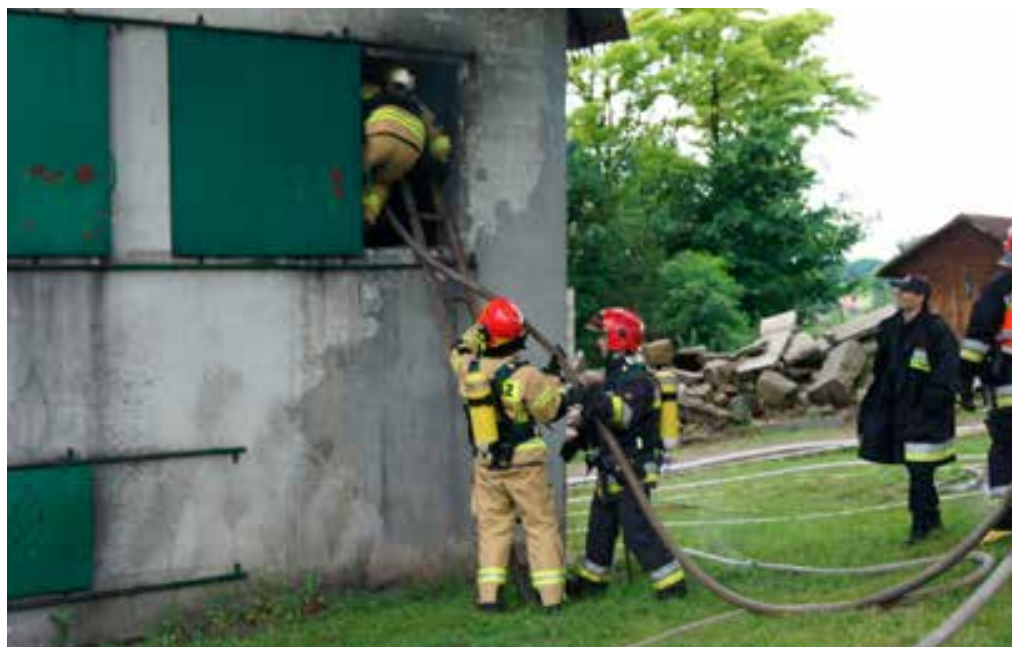

Ryc. 8. Testowanie ubrań podczas działań na stanowisku: Pożar w budynku mieszkalnym Źródło: Opracowanie własne CNBOP-PIB.

\section{Stanowisko 7: Komora rozgorzeniowa}

Testy w komorze rozgorzeniowej miały na celu sprawdzenie odporności termicznej ubrania oraz ocenę komfortu użytkowania $\mathrm{z}$ aparatami powietrznymi przy podwyższonej temperaturze i znacznym zadymieniu.

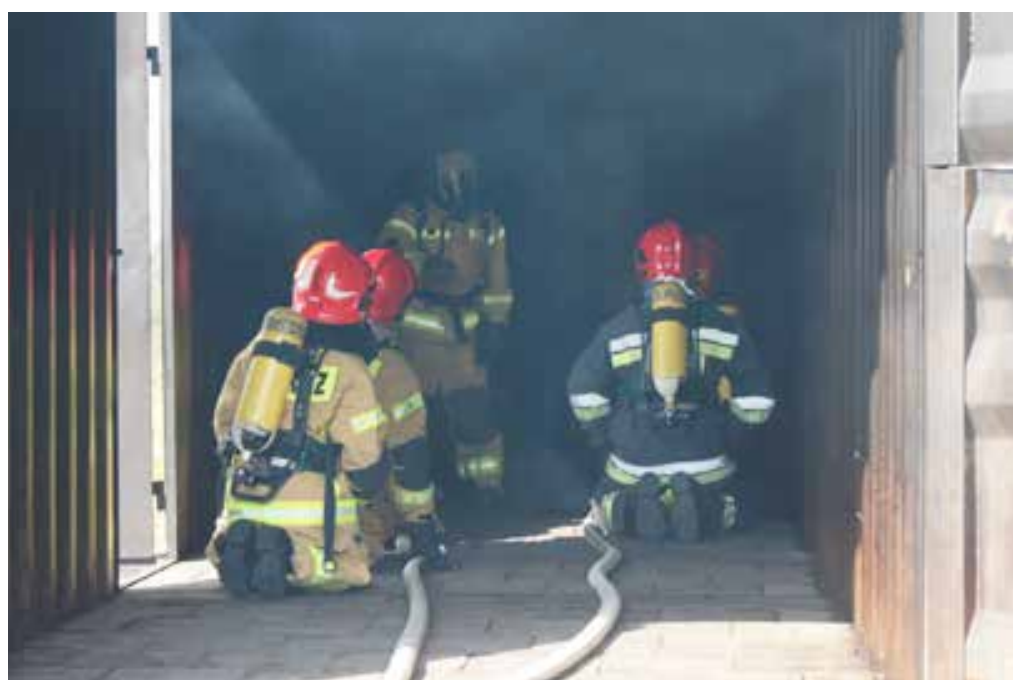

Ryc. 9. Testowanie ubrań podczas działań na stanowisku: komora rozgorzeniowa Źródło: Opracowanie własne CNBOP-PIB. 


\section{Stanowisko 8: Ewakuacja z samolotu}

Zadanie polegało na rozpoznaniu terenu zdarzenia, przygotowaniu terenu akcji (zabezpieczenie, wyznaczenie strefy bezpiecznej, podłączenie linii wężowych itd.), działaniu ekipy ratowniczej, ewakuacji poszkodowanych oraz udzieleniu pierwszej pomocy osobom poszkodowanym.

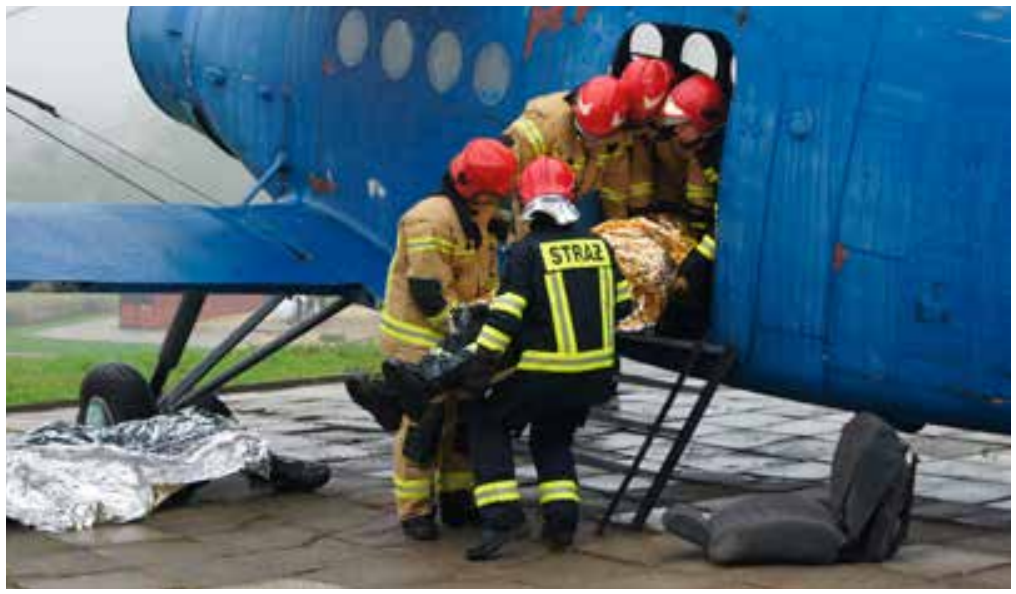

Ryc. 10. Testowanie ubrania podczas działań na stanowisku: Ewakuacja z samolotu - pomoc rannym Źródło: Opracowanie własne CNBOP-PIB.

\section{Stanowisko 9: Ewakuacja z autobusu}

Zadanie polegało na rozpoznaniu terenu zdarzenia, przygotowaniu terenu akcji (zabezpieczenie, wyznaczenie strefy bezpiecznej, podłączenie linii wężowych itd.), działaniu ekipy ratowniczej, ewakuacji poszkodowanych oraz udzieleniu pierwszej pomocy osobom poszkodowanym.

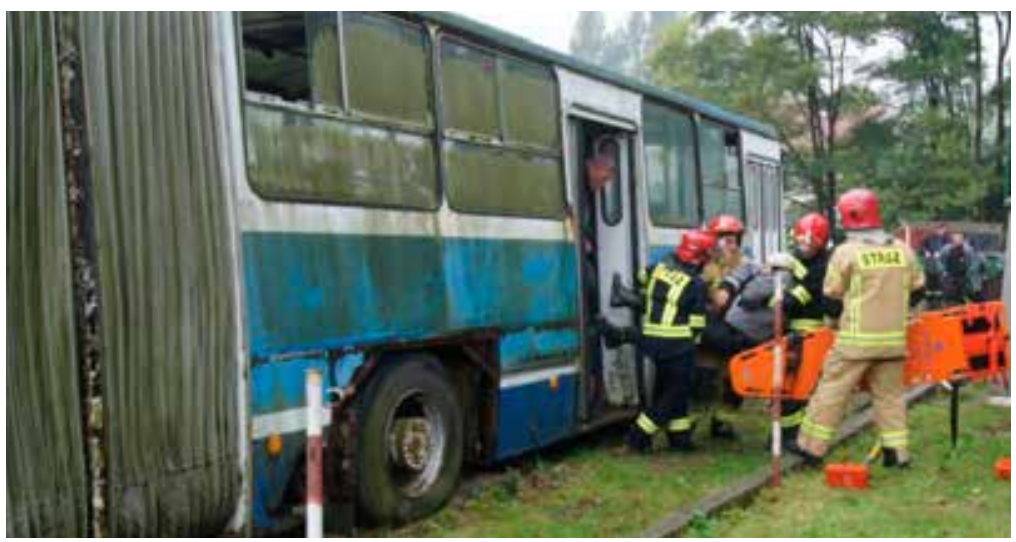

Ryc. 11. Testowanie ubrań podczas działań na stanowisku: Ewakuacja z autobusu - wynoszenie rannego

Źródło: Opracowanie własne CNBOP-PIB. 
Jako wskaźnik komfortu użytkowania nowych ochron osobistych przyjęto wyniki badań parametrów fizjologicznych. W trakcie badań dokonano pomiarów i poddano dalszej analizie parametry fizjologiczne: tętno, ciśnienie oraz saturację krwi. Do celów analitycznych/porównawczych wykonano te same badania na wybranej grupie ratowników podczas ćwiczeń w nowych i starych ochronach osobistych.

\section{Analiza przeprowadzonej ankiety dla ubrania specjalnego o ograniczonej masie i ubrania do działań ratowniczo-gaśniczych na przestrzeniach otwartych}

Analizę sporządzono na podstawie zawartych w ankietach spostrzeżeń użytkowników dwóch typów ubrań. Ankiety zostały wypełnione anonimowo po wykonaniu testów na stanowiskach poligonowych.

\section{Ubranie specjalne o ograniczonej masie}

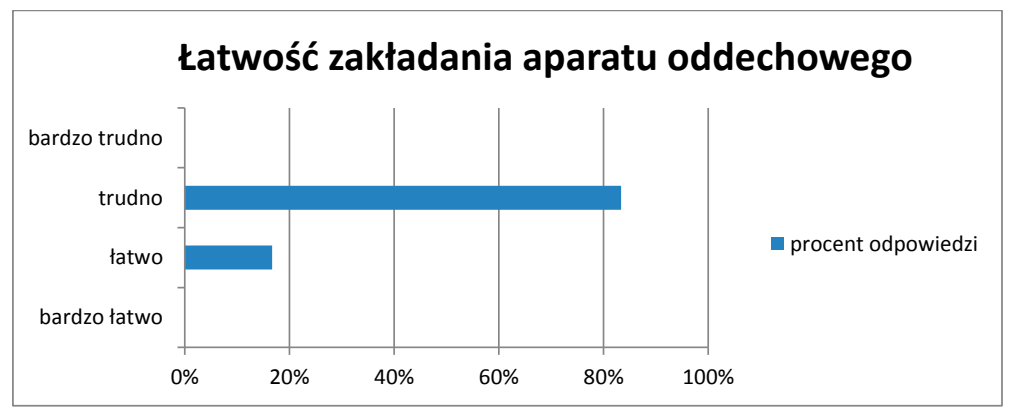

Ryc. 12. Zestawienie wyników analizy ankiety dla ubrania specjalnego o ograniczonej masie dotyczących łatwości zakładania aparatu oddechowego

Źródło: Opracowanie własne CNBOP-PIB.

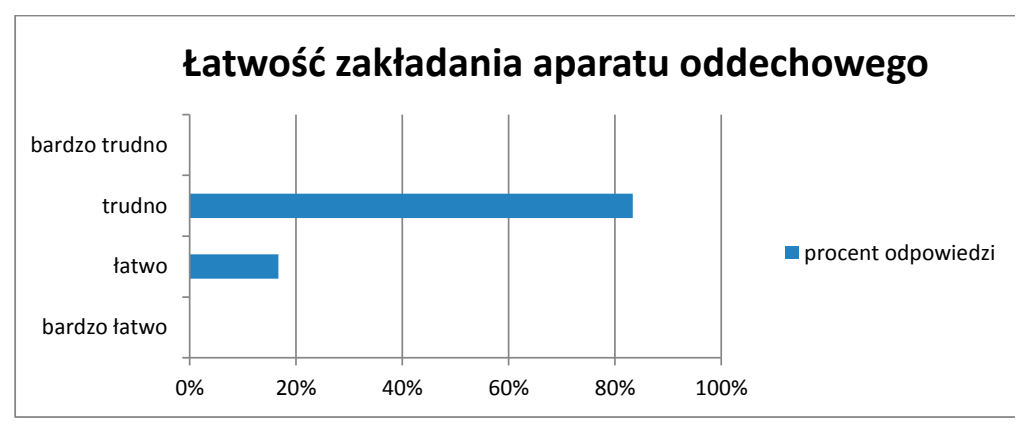

Ryc. 13. Zestawienie wyników analizy ankiety dla ubrania specjalnego o ograniczonej masie dotyczących odprowadzania ciepła z wnętrza ubrania

Źródło: Opracowanie własne CNBOP-PIB. 


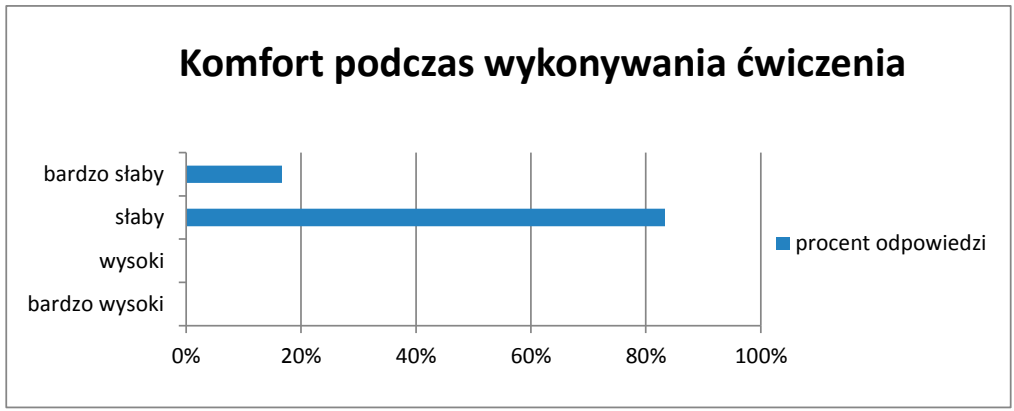

Ryc. 14. Zestawienie wyników analizy ankiety dla ubrania specjalnego o ograniczonej masie dotyczących komfortu podczas wykonywania ćwiczenia

Źródło: Opracowanie własne CNBOP-PIB.

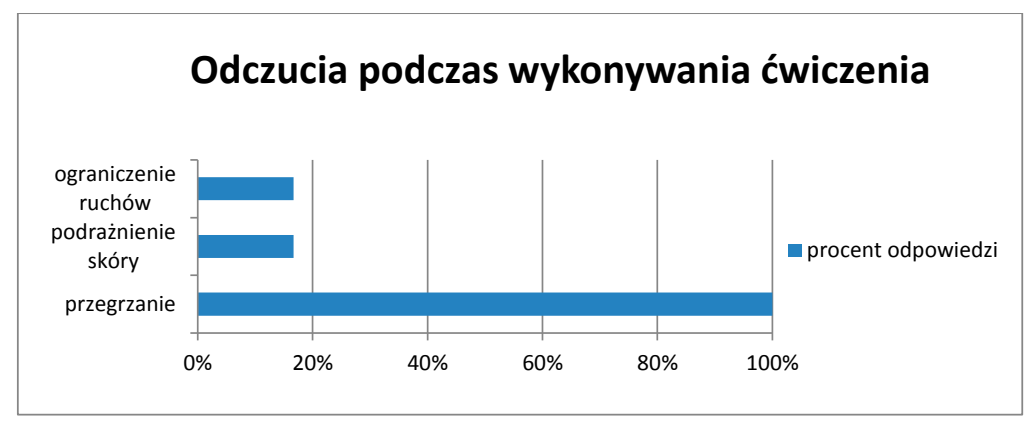

Ryc. 15. Zestawienie wyników analizy ankiety dla ubrania specjalnego o ograniczonej masie dotyczących odczuć podczas wykonywania ćwiczenia Źródło: Opracowanie własne CNBOP-PIB.

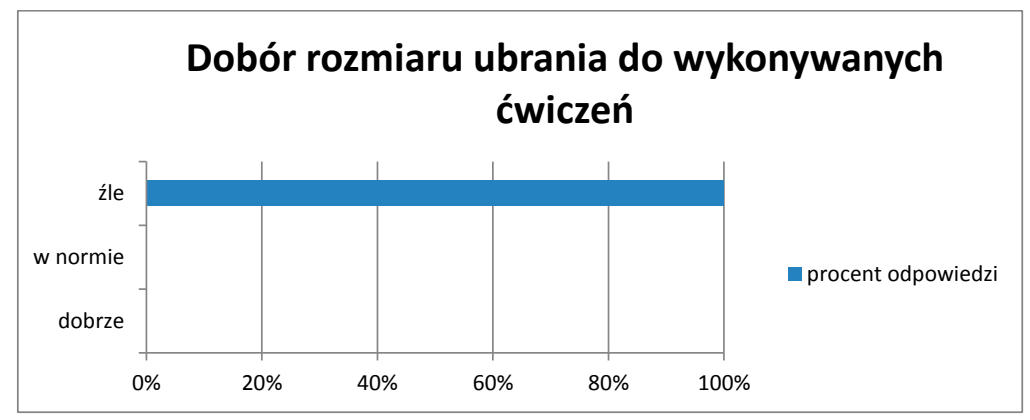

Ryc. 16. Zestawienie wyników analizy ankiety dla ubrania specjalnego o ograniczonej masie dotyczących doboru rozmiaru ubrania do wykonywanych ćwiczeń Źródło: Opracowanie własne CNBOP-PIB. 
Ubranie do działań ratowniczo-gaśniczych na przestrzeniach otwartych

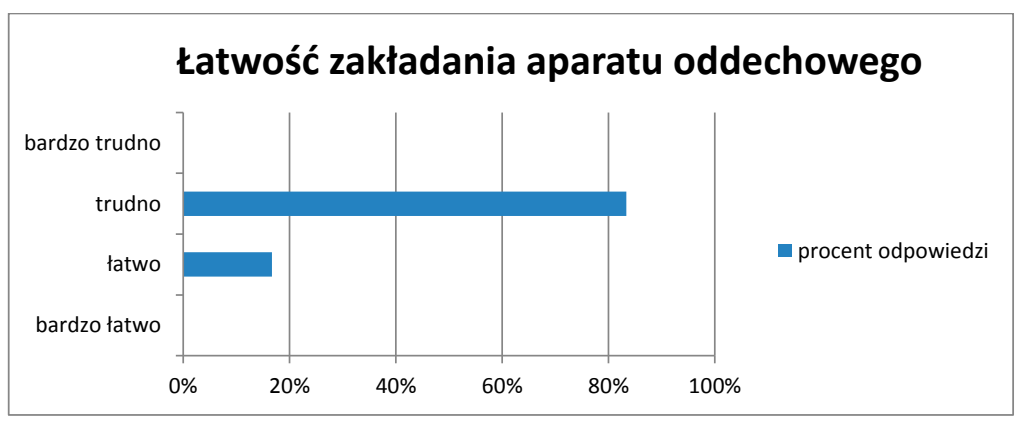

Ryc. 17. Zestawienie wyników analizy ankiety dotyczących łatwości zakładania aparatu oddechowego dla ubrania do działań ratowniczo-gaśniczych na przestrzeniach otwartych Źródło: Opracowanie własne CNBOP-PIB.

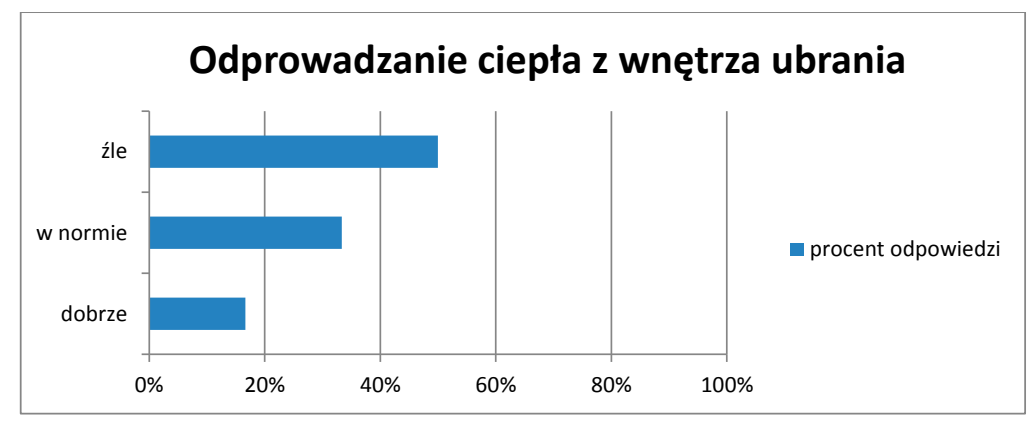

Ryc. 18. Zestawienie wyników analizy ankiety dotyczących odprowadzania ciepła z wnętrza ubrania dla ubrania do działań ratowniczo-gaśniczych na przestrzeniach otwartych Źródło: Opracowanie własne CNBOP-PIB.

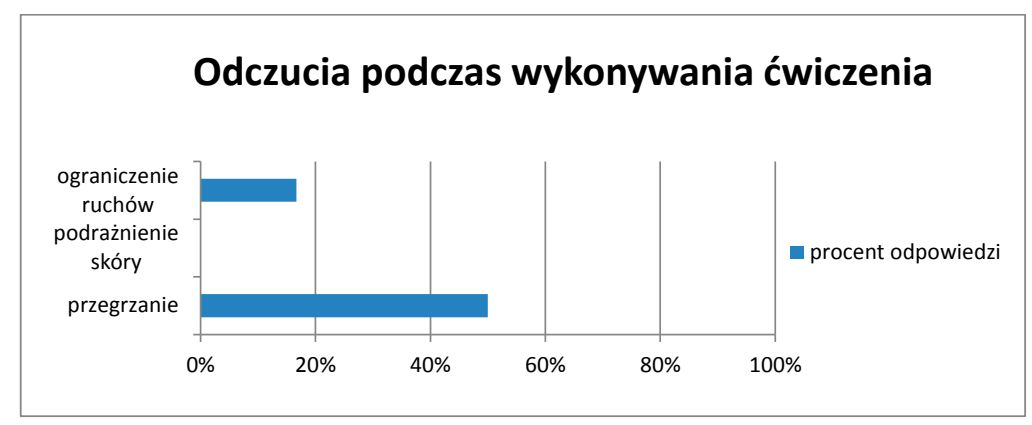

Ryc. 19. Zestawienie wyników analizy ankiety dotyczących odczuć podczas wykonywania ćwiczenia dla ubrania do działań ratowniczo-gaśniczych na przestrzeniach otwartych Źródło: Opracowanie własne CNBOP-PIB. 
Na podstawie wyników przeprowadzonych badań ankietowych po zrealizowanych testach w polu operacyjnym zostały uzyskane nw. wnioski dotyczące zaproponowanych rozwiązań konstrukcyjnych w poddanych badaniom ubraniach.

\section{Ubranie specjalne nowej generacji o maksymalnie ograniczonej masie}

Mocne strony ubrania:

- dobre rozwiązanie usztywnienia pleców,

- niewielka masa ubrania,

- dobre rozwiązanie wszytej półrękawiczki w rękawy,

- dobre rozwiązanie usztywnienia kolan,

- dobre rozmieszczenie kieszeni i uchwytów,

- dobra kolorystyka i elementy odblaskowe,

- wygodny krój krocza spodni - uczucie komfortu podczas poruszania się.

Zastrzeżenia i wątpliwości użytkowników:

- odczucie źle dobranych rozmiarów ubrań (rzeczywiste wymiary ubrań niezgodne $\mathrm{z}$ wymiarami podanymi na metce), kurtka powinna być węższa w pasie, natomiast szersza w barkach;

- odczucie dyskomfortu termicznego bezpośrednio po założeniu ubrania, nasilającego się podczas wykonywania ćwiczenia:

- po wykonaniu ćwiczenia wewnętrzna strona ubrania była zawilgocona,

- brak oddychalności oraz brak odprowadzania wilgoci i ciepła,

- nieodpowiednia konstrukcja kołnierza: zbyt wysoki, mało elastyczny, krępuje ruchy, obciera twarz (widoczne zaczerwienienie skóry po wykonaniu ćwiczenia),

- nieodpowiednia konstrukcja nogawek: za luźne, zbyt obszerne,

- nieodpowiednia konstrukcja rękawów: zbyt krótkie, za luźne, zbyt obszerne, użytkownicy mieli trudności z nałozeniem mankietu rękawic na rękaw kurtki,

- materiał zakładki chroniącej suwak bardzo utrudniał zasuwanie kurtki,

- nieodpowiednie działanie zapięcia z przodu kurtki, zamek trudno się zapinał - użytkownicy zaproponowali zastosowanie rzepa przez całą długość kurtki,

- nieodpowiednie rozwiązanie dotyczące podzielonego rzepa z zatrzaskami - użytkownik zbyt dużo czasu traci na zapinanie się,

- zbyt mała szerokość szelek spodni,

- ubranie podwija się i ogranicza ruchy w wąskich przejściach komory dymowej.

\section{Ubrania do działań ratowniczo-gaśniczych na przestrzeniach otwartych}

Mocne strony ubrania:

- ubranie wygodniejsze (bardziej przylega do ciała) niż ubranie specjalne o ograniczonej masie, 
- brak problemów przy zakładaniu,

- brak problemów z poruszaniem się w ubraniu,

- brak problemów z zakładaniem aparatu Ochrony Dróg Oddechowych (ODO).

Zastrzeżenia i wątpliwości użytkowników:

- nieodpowiednia konstrukcja kurtki: zbyt wąska w klatce piersiowej i części barkowej, obecna konstrukcja powoduje uczucie opinania na plecach,

- przy wyciągnięciu rąk do przodu, użytkownik odczuwał krępowanie ruchów oraz opinanie na plecach,

- za wąski rzep zapinający osłonę suwaka; w części dolnej kurtki sam się rozpina,

- propozycja użytkownika: zastosowanie jednego dłuższego rzepa w zapięciu kurtki,

- podczas ćwiczenia na młocie, ćwiczący odczuwał niekomfortowe napinanie się kurtki na szwach w górnej części,

- propozycja użytkownika: zastosowanie na kolanach wkładek z bardziej miękkiego materiału lub zastosować inną konstrukcję wkładek uzyskując ten efekt,

- za krótkie spodnie,

- ubranie nie wchłaniania potu,

- ubranie nie odprowadzania ciepła,

- zbyt wąskie szelki spodni,

- propozycja użytkownika: zastosowanie odblasków zamiast materiałów fluorescencyjnych,

- podczas zakładania kurtki przez użytkownika pękło szycie zakładki na plecach w górnej części,

- podczas przechodzenia przez komorę dymową urwał się zaczep, na którym był powieszony czujnik bezruchu.

Po zakończeniu pierwszej serii badań poligonowych uwagi potencjalnych użytkowników przekazano konsorcjantom, którzy w projekcie byli odpowiedzialni za przygotowanie wzorów do badań. W wyniku prac konstrukcyjnych prowadzonych w ścisłej współpracy z Biurem Logistyki KGPSP - przedstawicielem Gestora nadzorującego projekt, została wykonana kolejna partia próbna ubrań poddana ponownym badaniom wg wcześniej opracowanych metodyk .

\section{II etap testów eksperckich po poprawach konstrukcyjnych}

Obydwa typy ubrań sprawdzono pod względem komfortu użytkowania, oddychalności, wygody poruszania się, itp. Podczas testów ćwiczący realizowali następujące zadania:

- pokonywanie różnych poziomów,

- otwieranie przegród pionowych, poziomych i diagonalnych, 
- przejście przez zbiornik,

- przechodzenie przez otwory,

- przejście przez odcinki rurowe,

- poruszanie się w pomieszczeniach o różnych wysokościach,

- pokonywanie strefy zadymionej i cieplnej,

- poruszanie się po nierównym terenie o różnych wysokościach,

- przenoszenie gruzu,

- pokonywanie strefy cieplnej,

- klękanie na różnorodnym podłożu, np. ostrych krawędziach kamieni,

- wykonywanie czynności wymagających użycia siły,

- wykonywanie czynności związanych z obsługą i użyciem narzędzi hydraulicznych,

- przenoszenie elementów pojazdu po odcięciu, posiadających ostre krawędzie o nieregularnych kształtach, np. dach i drzwi samochodu,

- rozwijanie węży pożarniczych,

- wykonywanie czynności, podczas których ruchy nie mogą być krępowane,

- wykonywanie czynności na czas,

- udzielanie pierwszej pomocy.

\section{Analiza przeprowadzonej ankiety dla ubrania specjalnego o ograniczonej masie i ubrania do działań ratowniczo-gaśniczych na przestrzeniach otwartych}

Analizę sporządzono na podstawie zawartych w ankietach spostrzeżeń użytkowników dwóch typów ubrań. Ankiety zostały wypełnione anonimowo po wykonaniu testów na stanowiskach poligonowych.

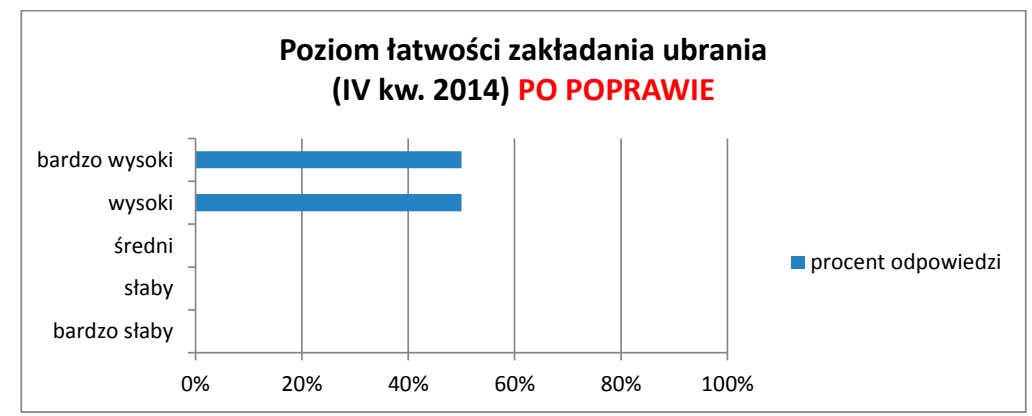

Ryc. 20. Zestawienie wyników analizy ankiety dotyczących poziomu łatwości zakładania ubrania Źródło: Opracowanie własne CNBOP-PIB. 


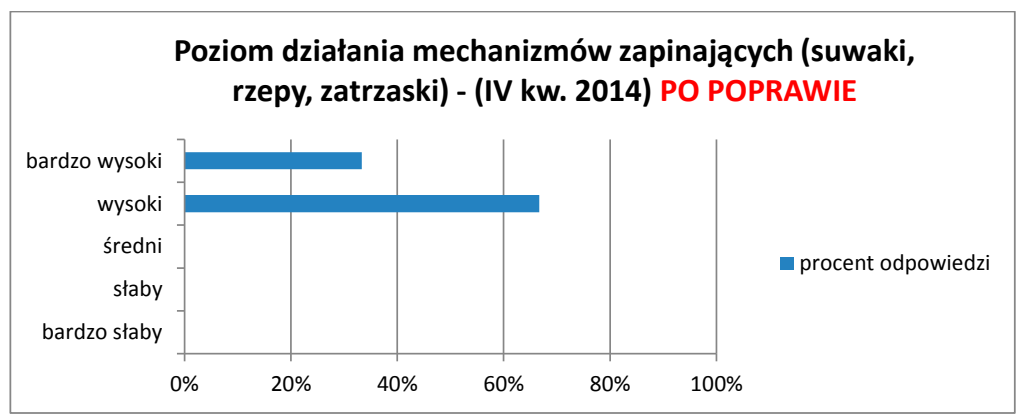

Ryc. 21. Zestawienie wyników analizy ankiety dotyczących poziomu działania mechanizmów zapinających

Źródło: Opracowanie własne CNBOP-PIB.

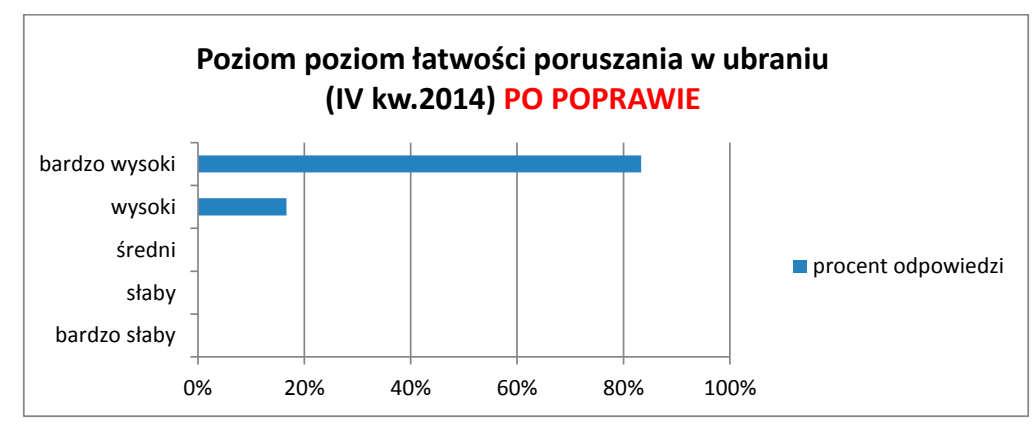

Ryc. 22. Zestawienie wyników analizy ankiety dotyczących poziomu łatwości poruszania w ubraniu

Źródło: Opracowanie własne CNBOP-PIB.

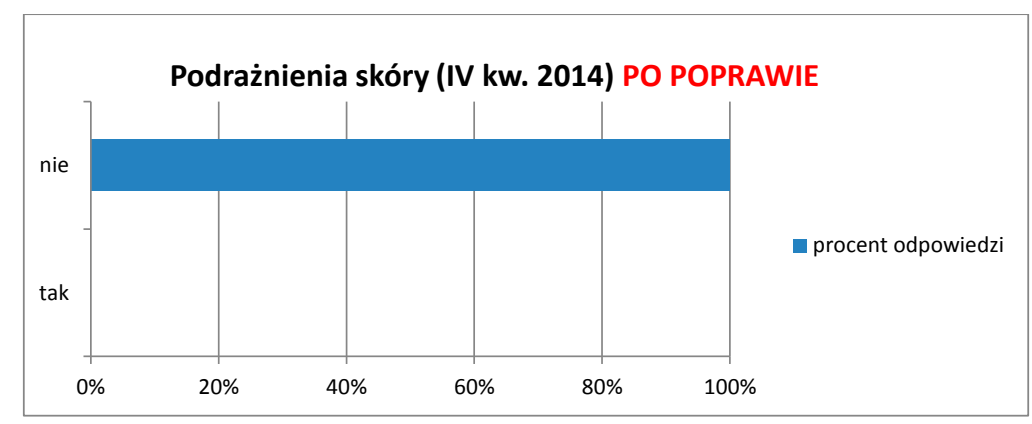

Ryc. 23. Zestawienie wyników analizy ankiety dotyczących odczuć podrażnienia skóry Źródło: Opracowanie własne CNBOP-PIB. 


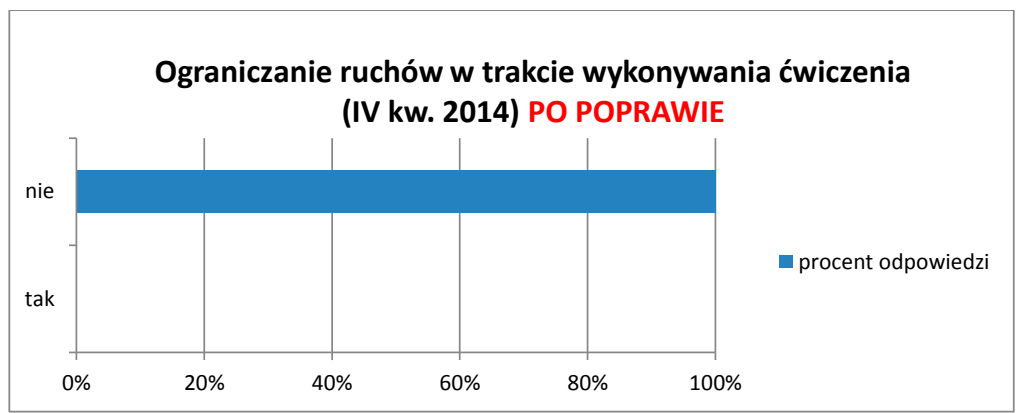

Ryc. 24. Zestawienie wyników analizy ankiety dotyczących ograniczania ruchów w trakcie wykonywania ćwiczenia

Źródło: Opracowanie własne CNBOP-PIB.

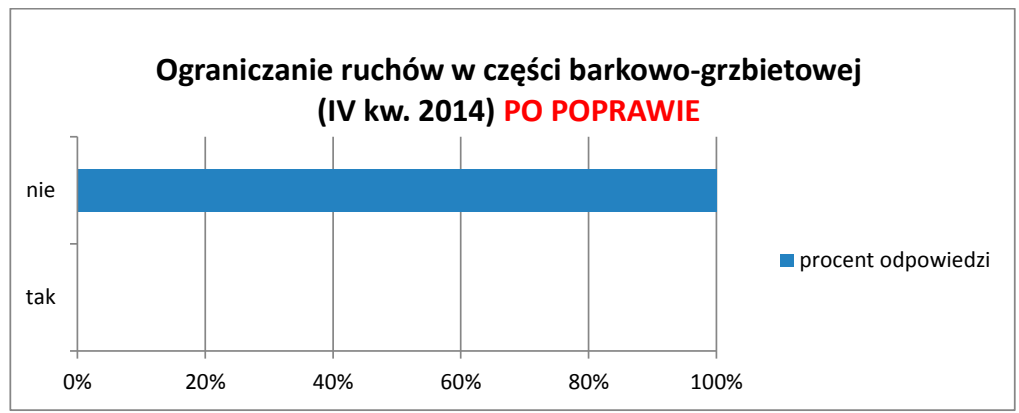

Ryc. 25. Zestawienie wyników analizy ankiety dotyczących ograniczania ruchów w części barkowo-grzbietowej

Źródło: Opracowanie własne CNBOP-PIB.

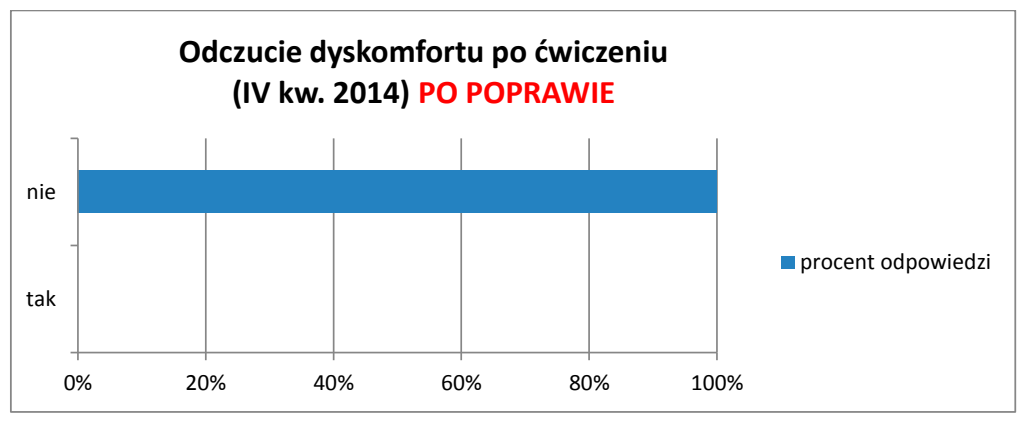

Ryc. 26. Zestawienie wyników analizy ankiety dotyczących odczucia dyskomfortu po ćwiczeniu

Źródło: Opracowanie własne CNBOP-PIB. 


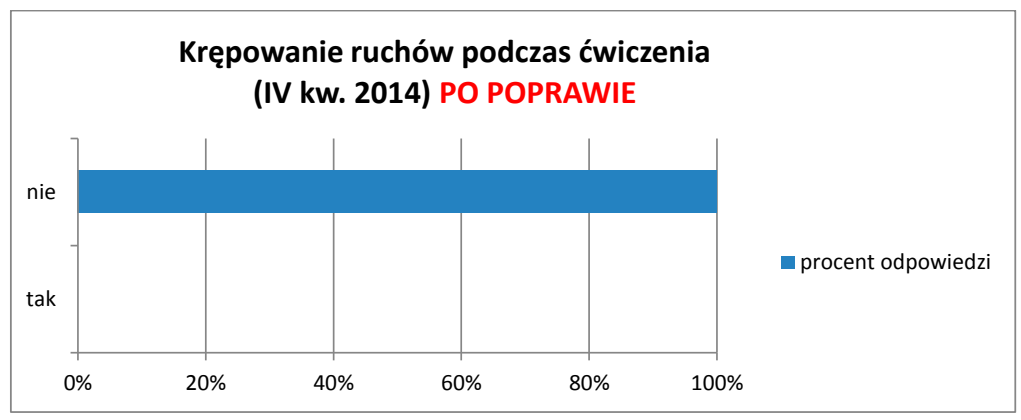

Ryc. 27. Zestawienie wyników analizy ankiety dotyczących krępowania ruchów podczas ćwiczenia

Źródło: Opracowanie własne CNBOP-PIB.

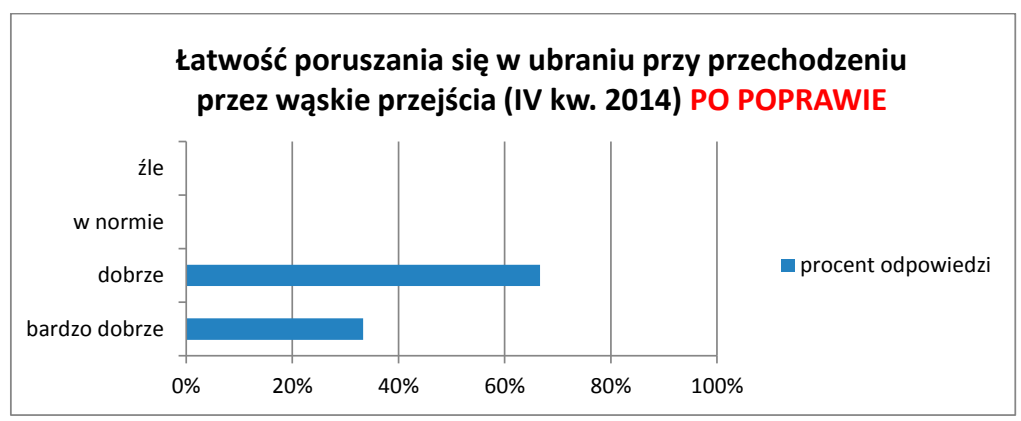

Ryc. 28. Zestawienie wyników analizy ankiety dotyczących łatwości poruszania się w ubraniu przy przechodzeniu przez wąskie przejścia

Źródło: Opracowanie własne CNBOP-PIB.

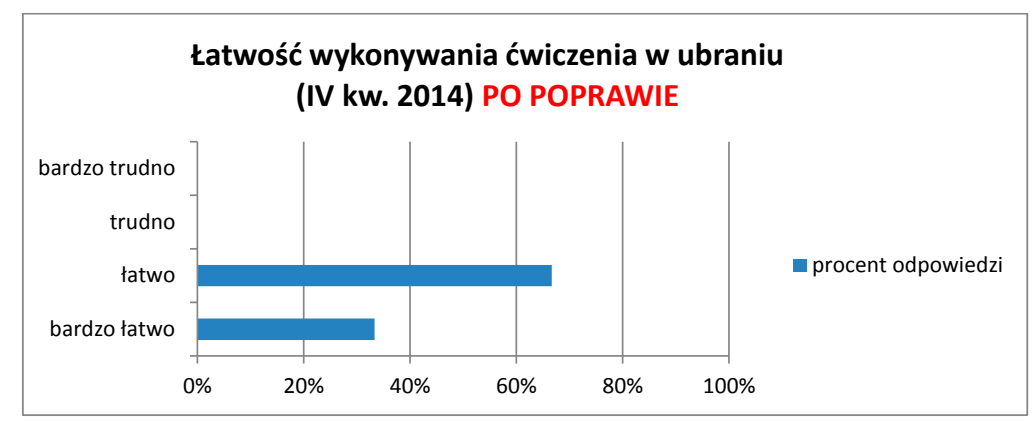

Ryc. 29. Zestawienie wyników analizy ankiety dotyczących łatwości wykonywania ćwiczenia w ubraniu

Źródło: Opracowanie własne CNBOP-PIB. 


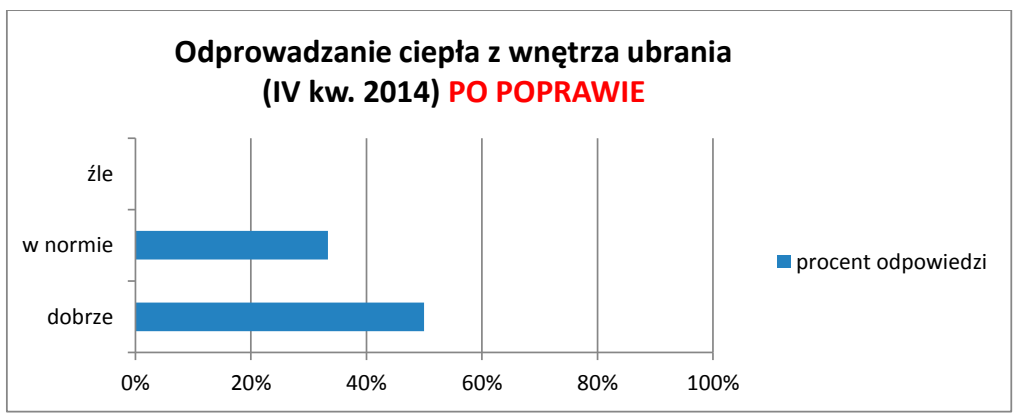

Ryc. 30. Zestawienie wyników analizy ankiety dotyczących odprowadzania ciepła z wnętrza ubrania

Źródło: Opracowanie własne CNBOP-PIB.

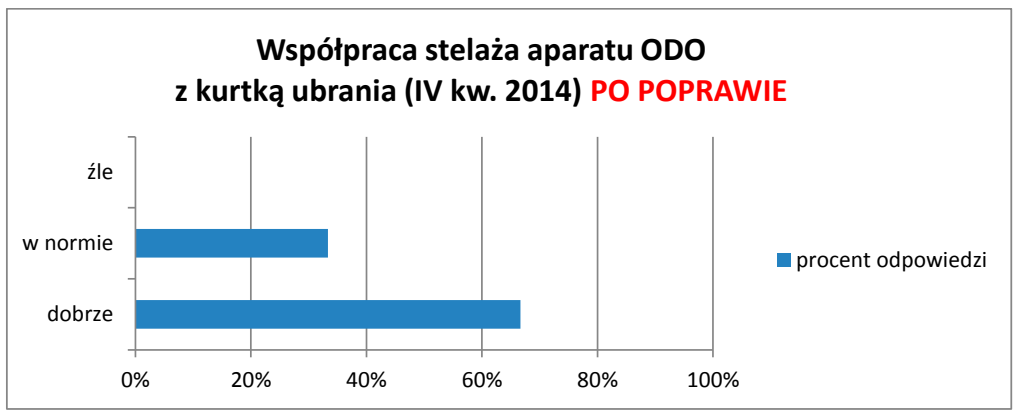

Ryc. 31. Zestawienie wyników analizy ankiety dotyczących współpracy stelaża aparatu ODO z kurtką ubrania

Źródło: Opracowanie własne CNBOP-PIB.

\section{Ubranie specjalne o ograniczonej masie}

W początkowej fazie testów użytkownicy skarżyli się na zbyt duże rozmiary ubrań, niezgodne $\mathrm{z}$ wymiarami podanymi na metce (według użytkowników kurtka powinna być węższa w pasie, natomiast szersza w barkach, spodnie powinny posiadać węższe nogawki). W związku $\mathrm{z}$ tym ubranie specjalne o ograniczonej masie w końcowej fazie testów zostało uszyte według podanych niżej rozmiarów:

- 166-170/98-102/86-90,

- 174-178/102-106/90-95,

- 178-182/106-110/95-100,

- 182-186/106-110/95-100,

- 194-198/114-118/105-110.

W końcowej fazie testów została poprawiona także konstrukcja zbyt wysokiego kołnierza, który teraz nie krępuje ruchów i nie podrażnia skóry twarzy. 
Ubranie zostało pozytywnie ocenione przez użytkowników, a najczęściej powtarzające się wypowiedzi to:

- dobre rozwiązanie usztywnienia pleców,

- niewielka masa ubrania,

- dobre rozwiązanie półrękawiczki wszytej w rękawy, kompatybilne z rękawicą,

- dobre rozwiązanie usztywnienia kolan,

- wygodny krój krocza spodni - uczucie komfortu podczas poruszania się,

- dobre rozmieszczenie kieszeni i uchwytów,

- dobra kolorystyka i elementy odblaskowe,

- dużo kieszeni,

- wygodne do zapinania rzepy,

- dobrze odprowadza ciepło $\mathrm{z}$ wnętrza ubrania,

- brak ograniczeń w części barkowo-grzbietowej podczas ruchów,

- odpowiednio dobrana kolorystyka,

- rozcięcie na wstawkach w kolanach, komfort podczas klękania,

- wzmocnienia na kciuk,

- kurtka odpowiedniej długości (krótsza w porównaniu do kurtek starego typu), zapewnia ochronę pleców,

- na spodniach odstająca, dość duża, dobrze otwierająca się kieszeń.

\section{Ubranie do działań ratowniczo-gaśniczych na przestrzeniach otwartych}

W początkowej fazie testów użytkownicy skarżyli się na nieodpowiednią konstrukcję kurtki, a mianowicie zbyt wąską w klatce piersiowej i części barkowej oraz, że konstrukcja powoduje uczucie opinania na plecach, a przy wyciągnięciu rąk do przodu, użytkownik odczuwał krępowanie ruchów. W związku z tym ubranie do działań ratowniczo-gaśniczych na przestrzeniach otwartych w końcowej fazie testów zostało uszyte według podanych niżej rozmiarów:

- 166-170/98-102/86-90,

- 174-178/102-106/90-95,

- 178-182/106-110/95-100,

- 182-186/106-110/95-100,

- 190-194/110-114/100-105,

W końcowej fazie testów została poprawiona także konstrukcja zbyt wysokiego kołnierza, który teraz nie krępuje ruchów i nie podrażnia skóry twarzy.

Ubranie zostało pozytywnie ocenione przez użytkowników, a najczęściej powtarzające się wypowiedzi to:

- wygodne wykończenie rękawa,

- ubranie wygodniejsze (bardziej przylega do ciała), niż ubranie specjalne o ograniczonej masie,

- brak problemów przy zakładaniu,

- brak problemów z poruszaniem się $\mathrm{w}$ ubraniu, 
- brak problemów z zakładaniem aparatu Ochrony Dróg Oddechowych,

- ubranie zapewnia swobodę ruchów oraz wygodę użytkowania,

- ubranie nie stwarzało problemów przy zakładaniu,

- według użytkownika jest to ubranie ,idealne do działań ratowniczo-gaśniczych".

\section{Wnioski}

Oba typy ubrań zostały przebadane zgodnie z procedurą testowania wyrobów innowacyjnych zatwierdzoną przez Komendę Główną Państwowej Straży Pożarnej. Otrzymane wyniki oraz analiza parametrów pracy ratownika jest podstawą do stworzenia systemu diagnostycznego. Powstałe Lokalne Środowisko Badawcze umożliwi badania ergonomiczne, a dzięki budowie odpowiedniego oprogramowania umożliwi ocenę stanu zdrowia funkcjonariuszy.

Przeprowadzenie badań wg opracowanych procedur i programów pozwoli na:

- wdrożenie do produkcji nowego produktu, którym będą ubranie strażackie o maksymalnie ograniczonej masie oraz ubranie strażackie do działań ratowniczo-gaśniczych na przestrzeniach otwartych,

- wypracowanie rekomendacji do nowelizacji wymagań techniczno-użytkowych wyposażenia straży pożarnej oraz wytycznych dla producentów ubrań strażackich w zakresie poprawy ich funkcjonalności. 



\title{
WPEYW KONSTRUKCJI UBRAŃ SPECJALNYCH NA PARAMETRY WYDOLNOŚCIOWE RATOWNIKA
}

\author{
Tomasz Węsierski \\ Przemysław Kowalczyk
}

Praca ratownika $\mathrm{w}$ strefie zagrożenia wiąże się $\mathrm{z}$ dużym temperaturowym dyskomfortem fizycznym ${ }^{1}$. Wpływa to na wydajność jego pracy, obniża szybkość i dokładność wykonywanych zadań oraz zdolność do podejmowania decyzji. Nie jest to bez znaczenia podczas długotrwałych działań ratowniczo-gaśniczych, zwłaszcza w warunkach dużych obciążeń termicznych. W warunkach działań ratowniczych zapewnienie komfortu psychofizycznego ratownikowi jest trudne, ale możliwe przy pomocy profesjonalnego wyposażenia, które pozwala na prowadzenie działań z dystansu, czy też dzięki jego automatyzacji, lub choćby przez dobór właściwych parametrów wydajności armatury pożarniczej. Nie wszystkie działania da się jednak wykonać zdalnie i konieczne jest wejście ratownika w rejon wysokiego poziomu zagrożenia. Stąd też konstrukcja ubrań specjalnych przechodzi ciągłą ewolucję celem poprawy bezpieczeństwa oraz komfortu pracy ratownika w czasie działań ratowniczo-gaśniczych. Realizacja tego zadania odbywa się choćby poprzez zmniejszenie wagi ubrania specjalnego, stosowanie coraz bardziej odpornych materiałów zapobiegających wnikaniu płomienia do środka oraz o coraz większej odporności mechanicznej. Nie bez znaczenia jest także dobór odpowiednich membran paroprzepuszczalnych oraz zastosowanie odpowiedniej bielizny podbarierowej gwarantującej lepszy odbiór potu. Stąd też w ramach projektu rozwojowego nr O ROB 001401 pt. „Nowoczesne ochrony służb ratowniczych KSRG w oparciu o potrzeby użytkowników końcowych" skupiono się na stworzeniu dwóch nowych typów ubrań specjalnych, wychodzących naprzeciw oczekiwaniom użytkowników końcowych:

1 A. Dmochowska, M. Majder-Łopatka, W. Jarosz, Praca strażaka ratownika $w$ chemoodpornym ubraniu gazoszczelnym $w$ aspekcie fizycznego obciązenia organizmu, „Zeszyty Naukowe SGSP”, 46 (2013) 31-39; P. Guzewski, R. Pawłowski, J. Ranecki, Ubrania ochrony przeciwchemicznej, SA PSP, wyd. I, Poznań 1997; A. Czarnecka, C. Dobrodziej, Psychologiczne aspekty działań ratowniczych, ZWiS, Warszawa 2001; A. Świderski, Źródła stresu zawodowego, jego objawy i skutki ekonomiczne dla przedsiębiorstwa, Seminarium Okręgowego Inspektoratu Pracy w Łodzi „Stres w pracy”, 15 listopada 2006; T.L. Guidotti, Human factors in firefighting: ergonomic-, cardiopulmonary-, and psychogenic stressrelated issues, International Archive of Occupational and Environmental Health, 64 (1992), 1-12; S.N. Kales, E.S.Soteriades, C.A.Christophi, D.C.Christiani, Emergency duties and deaths from heart disease among firefighters in the United States, The New England Journal of Medicine, 356 (2007), 1207-1215; M.S. Sothmann, K. Saupe, D. Jasenof, J. Blaney, Heart rate response of firefighters to actual emergencies; implications for cardiorespiratory fitness, "Journal of Occupational Medicine", 34 (1992), 797-800. 
a) ubranie specjalne nowej generacji o maksymalnie obniżonej masie spełniające wymogi rozporządzenia MSWiA z dnia 27 kwietnia 2010 r. w sprawie wykazu wyrobów służących zapewnieniu bezpieczeństwa publicznego lub ochronie zdrowia i życia oraz mienia, a także zasad wydawania dopuszczenia tych wyrobów do użytkowania. Ubranie to oznaczono jako USNG i taka nazwa będzie stosowana w niniejszej publikacji;

b) ubranie specjalne nowej generacji przeznaczone do działań w przestrzeni otwartej. Wymogi dla tego typu ubrań nie są określone w rozporządzeniu MSWiA z dnia 27 kwietnia 2010 r. Ubranie to oznaczono jako USPO i taka nazwa będzie stosowana w niniejszej publikacji.

Ze względu na specyfikę pracy ratownika precyzyjne określenie poziomu wysiłku nie jest łatwe i wymaga zastosowania technik pomiarowych opartych na badaniu różnych parametrów organizmu człowieka takich jak zmiany częstości skurczów serca (HR), wentylacja minutowa płuc (VE), zużycie tlenu $\left(\mathrm{VM}_{\mathrm{O} 2}\right)$ czy też częstość oddechu (BF) w warunkach symulowanego obciążenia. Pewne $\mathrm{z}$ wymienionych parametrów organizmu takie jak HR oraz VE udało się zbadać w warunkach rzeczywistych działań ratowniczo-gaśniczych, co pozwoliło na określenie reakcji organizmu w zależności od rodzaju działającego bodźca psychofizycznego ${ }^{2}$. Okazuje się bowiem, że przyczyną aż $44 \%$ wypadków śmiertelnych wśród strażaków w USA w okresie pomiędzy 1995-2007 była nagła niewydolność serca ${ }^{3}$. Poznanie zatem wpływu poszczególnych stresorów jest konieczne celem poprawy bezpieczeństwa pracy.

\section{Metodyka badań}

Badania przedstawione w niniejszej publikacji wykonano na ergospirometrze Start 2000M. Jest to urządzenie przenośne służące do prowadzenia testów wydolnościowych w warunkach laboratoryjnych lub w warunkach naturalnego wysiłku (bieg, jazda na rowerze itp.) z możliwością bezpośredniego podglądu mierzonych wielkości. Dzięki zastosowaniu niskooporowej głowicy pneumotachograficznej istnieje możliwość wielogodzinnego pomiaru wentylacji minutowej płuc, a zamontowane analizatory $\mathrm{CO}_{2}, \mathrm{O}_{2}$ oraz system do bezprzewodowej rejestracji pulsu dają możliwość pełnego zapisu najważniejszych parametrów ergospirometrycznych podczas pracy. Urządzenie zostało połączone przewodowo z komputerem, na którym zainstalowano oprogramowanie Ergo2k służące

2 Zob. Physiological Stress Associated with Structural Firefighting Observed in Professional Firefighters, Indiana University Firefighter Health \& Safety Research School of Health, Physical Education \& Recreation Department of Kinesiology Bloomington, Indiana 2011.

3 Zob. R.F. Fahy, U.S. firefighter fatalities due to sudden cardiac death, 1995-2004, Quincy, MA: National Fire Protection Association, 2005; U.S. Fire Administration, Firefighter fatalities in the United States in 2006, Emmitsburg, MD, 2006. 
do obróbki danych pochodzących z ergospirometru Start 2000M. W toku badań istnieje możliwość pomiaru takich parametrów jak tętno (HR), wentylacja minutowa płuc (VE), zużycie tlenu $\left(\mathrm{VM}_{\mathrm{O} 2}\right)$, częstość oddechu (BF). Szczegółowej analizie w niniejszej publikacji zostanie poddany jednakże najbardziej wiarygodny parametr, jakim jest zużycie tlenu $\mathrm{VM}_{\mathrm{O} 2}$ wyrażający objętość skonsumowanego tlenu w jednostce czasu w przeliczeniu na kilogram masy ratownika ( $\left.\mathrm{dm}^{3} \mathrm{~kg}^{-1} \mathrm{~min}^{-1}\right)$. W związku z odniesieniem się w części wnioskowej do publikacji Physiological Stress Associated with Structural Firefighting Observed in Professional Firefighters przeprowadzono także badania porównawcze wentylacji minutowej płuc $(\mathrm{VE})^{4}$. W toku badań przeanalizowano dwa tryby obciążenia:

a) pracę w postaci szybkiego marszu na bieżni ( $\mathrm{v}=7 \mathrm{~km} / \mathrm{h})$, której poddano ratownika w wieku średnim, o przeciętnej budowie ciała $(179 \mathrm{~cm}, 92 \mathrm{~kg}, 36 \mathrm{lat})$. Wysiłek poprzedzono czterominutowym okresem spoczynkowym;

b) pracę na dwóch stanowiskach (drabina bez końca oraz cykloergometr) trwającą po sześć minut w każdym przypadku i oddzieloną od siebie czasem koniecznym na przejście od jednego do drugiego stanowiska pomiarowego (1 minuta). Osoba badana: wzrost $178 \mathrm{~cm}$, masa $75 \mathrm{~kg}$, wiek 22 lata. Wysiłek poprzedzono czterominutowym okresem spoczynkowym.

Badania każdego typu ubrania dla każdej osoby powtarzano pięciokrotnie, odnosząc je do wyników badań w stroju sportowym, które stanowiły pomiar odniesienia obrazujący stan idealnego komfortu pracy (brak krępacji ruchu, swobodna wymiana termiczna oraz brak ograniczeń przy doprowadzaniu potu). Każde badanie było wykonane na czczo, w różnych dniach, w pomieszczeniu zamkniętym o stabilnych warunkach temperaturowych oraz wilgotności $\left(21-22^{\circ} \mathrm{C}\right.$, wilgotność względna 33-41\%).

Użyte w badaniach „tradycyjne” ubranie specjalne spełniało wymagania normy PN-EN 469:2008. Ubranie składało się z kurtki 3/4 oraz spodni z szelkami. Obie części posiadały budowę warstwową, na którą składały się:

- warstwa zewnętrzna - chroniąca przede wszystkim przed wnikaniem płomieni i urazami mechanicznymi,

- membrana wodoszczelna i paroprzepuszczalna - chroniąca przed wnikaniem wilgoci do wewnątrz ubrania i przepuszczająca parę wodną $\mathrm{z}$ wnętrza ubrania,

- warstwa termoizolacyjna - chroniąca przed wnikaniem ciepła do wnętrza ubrania,

- podszewka - zabezpieczająca pozostałe warstwy od wewnątrz.

4 Zob. Physiological Stress Associated, dz. cyt. 
„Tradycyjne” ubranie specjalne wykorzystane w badaniach zgodnie z wymaganiami posiadało masę mniejszą o $3,8 \mathrm{~kg}^{5}$. Jego masa w przeliczeniu na jednostkę powierzchni była standardowa i wynosiła $620 \mathrm{~g} / \mathrm{m}^{2}$.

Trójwarstwowe ubranie USNG stworzone w ramach projektu rozwojowego $\mathrm{nr}$ O ROB 001401 pt. „Nowoczesne ochrony służb ratowniczych KSRG w oparciu o potrzeby użytkowników końcowych" posiadało konstrukcję warstwową różniącą się od „tradycyjnego" ubrania specjalnego jednolitą warstwą obejmującą membranę wodoszczelną i warstwę termoizolacyjną. Miało także mniejszą masę w przeliczeniu na jednostkę powierzchni $-450 \mathrm{~g} / \mathrm{m}^{2}$.

Natomiast ubranie USPO (także stworzone $w$ ramach projektu rozwojowego nr O ROB 001401 pt. „Nowoczesne ochrony służb ratowniczych KSRG w oparciu o potrzeby użytkowników końcowych") było ubraniem dwuwarstwowym składającym się z warstwy zewnętrznej oraz termoizolacyjnej. Jego masa w przeliczeniu na jednostkę powierzchni wynosiła $210 \mathrm{~g} / \mathrm{m}^{2}$.

Nie licząc masy ubrania, powstałe demonstratory systemu USNG oraz USPO posiadały także pewne polepszające komfort pracy modyfikacje konstrukcyjne, których nie miały dotychczas stosowane ubrania specjalne, między innymi:

- zamek antypaniczny,

- rodzaj użytego materiału,

- wstawki dystansowe na plecach,

- manszety rękawów celem nieobsuwania się rękawa ubrania,

- układ kieszeni,

- rozmiar i położenie kieszeni o regulowanej głębokości przeznaczonej na radiostację,

- mocowanie słuchawki radiostacji na kołnierzu ubrania,

- zabezpieczenie antywilgociowe kieszeni.

Jako obszary analityczne krzywych $\mathrm{VM}_{\mathrm{O} 2}=(\mathrm{t})$ przyjęto czterominutowy okres spoczynkowy oraz dwuminutowy okres obciążenia w jego fazie końcowej (oprócz częstości oddechowej BF, dla której przyjęto cały zakres obciążeniowy). Wynika to $\mathrm{z}$ faktu ustabilizowania się pracy organizmu w czasie wysiłku. Niepewności pomiarowe podano w formie iloczynu odchylenia standardowego od wartości średniej i współczynnika dystrybuanty rozkładu normalnego $\mathrm{N}(0,1)$ przyjętego na poziomie istotności $\alpha=0,1$. Jako najbardziej reprezentatywne analitycznie przyjęto badania, które stanowią wartość medialną ze wszystkich pięciu prób i przedstawiono je w części wynikowej w postaci wykresów.

5 Rozporządzenie MSWiA z dnia 27 kwietnia 2010 r. w sprawie wykazu wyrobów służących zapewnieniu bezpieczeństwa publicznego lub ochronie zdrowia i życia oraz mienia, a także zasad wydawania dopuszczenia tych wyrobów do użytkowania (Dz. U. Nr 85, poz. 553). 


\section{Wyniki i dyskusja}

Tak jak wspomniano w części dotyczącej metodyki badań, analizie w niniejszej publikacji został poddany najbardziej wiarygodny parametr, którym jest zużycie tlenu $\mathrm{VM}_{\mathrm{O} 2}$, wyrażający objętość skonsumowanego tlenu w jednostce czasu w przeliczeniu na kilogram masy ratownika $\left(\mathrm{dm}^{3} \mathrm{~kg}^{-1} \mathrm{~min}^{-1}\right)$.

\section{Porównanie zużycia tlenu $\mathrm{VM}_{\mathrm{O} 2}$ dla ratownika będącego w stroju sportowym oraz będącego w tradycyjnym ubraniu specjalnym}

Przeciętna wartość zużycia tlenu dla osoby będącej w stanie spoczynku wynosiła odpowiednio $\mathrm{VM}_{\mathrm{O} 2 \mathrm{sr} 1}+/-\Delta \mathrm{VM}_{\mathrm{O} 2 \mathrm{sr} 1}=3,4+/-0,1 \mathrm{dm}^{3} \mathrm{~kg}^{-1} \mathrm{~min}^{-1}$ zarówno dla osoby będącej w stroju sportowym, jak i w „tradycyjnym” ubraniu specjalnym (ryc. 1,2). Końcowy okres obciążenia charakteryzował się parametrami $\mathrm{VM}_{\mathrm{O} 2 \mathrm{sr} 2}+/-\Delta \mathrm{VM}_{\mathrm{O} 2 \mathrm{sr} 2}=17,8+/-0,1 \mathrm{dm}^{3} \mathrm{~kg}^{-1} \mathrm{~min}^{-1}$ (strój sportowy) oraz 20,2 $+/-0,1 \mathrm{dm}^{3} \mathrm{~kg}^{-1} \mathrm{~min}^{-1}$ (ubranie specjalne). Zatem różnica $\mathrm{VM}_{\mathrm{O} 2 \mathrm{sr} 2}-\mathrm{VM}_{\mathrm{O} 2 \mathrm{sr} 1}$ wynosi odpowiednio: $14,4+/-0,2 \mathrm{dm}^{3} \mathrm{~kg}^{-1} \mathrm{~min}^{-1}$ (strój sportowy) oraz 16,8+/- 0,2 $\mathrm{dm}^{3} \mathrm{~kg}^{-1} \mathrm{~min}^{-1}$ (ubranie specjalne). Otrzymany wynik wskazuje zatem, iż przeciętny przyrost zużycia tlenu w fazie końcowej obciążenia jest o 16,7\% wyższy dla ubrania specjalnego. Różnica wartości przyrostu $\mathrm{dVM}_{\mathrm{O} 2}$ zaczyna być obserwowana już przed drugą minutą cyklu pomiarowego odbywającego się pod obciążeniem (ryc. 3).

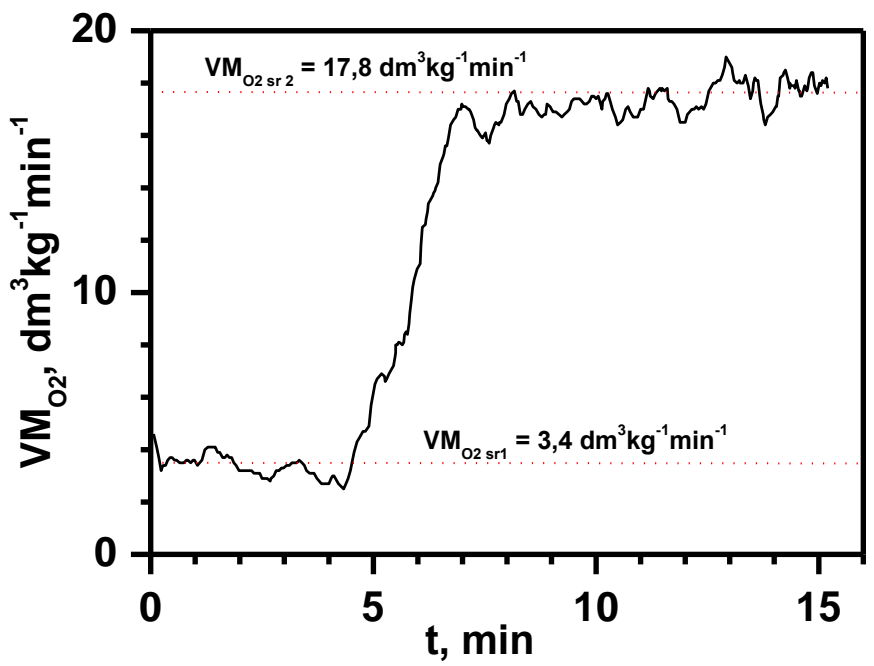

Ryc. 1. Zużycie tlenu $\mathrm{VM}_{\mathrm{O} 2}$ dla badań przeprowadzonych w stroju sportowym. Parametry badanego ratownika: wiek 36 lat, waga $92 \mathrm{~kg}$, wzrost $179 \mathrm{~cm}$. Obciążenie: szybki marsz $\mathrm{v}=7 \mathrm{~km} / \mathrm{h}$ poprzedzony okresem spoczynkowym $(4 \mathrm{~min})$

Źródło: Opracowanie własne. 


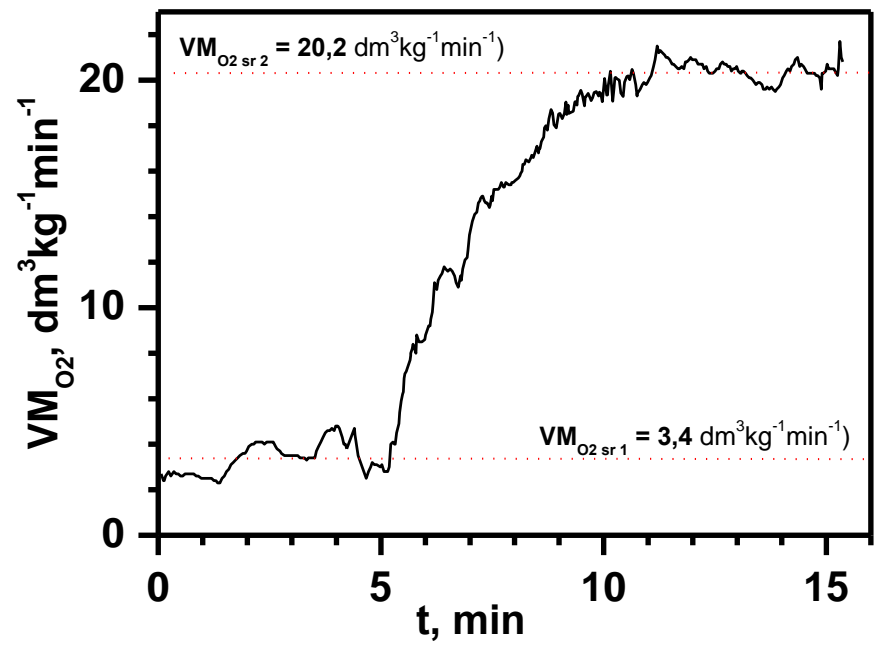

Ryc. 2. Zużycie tlenu $\mathrm{VM}_{\mathrm{O} 2}$ dla badań przeprowadzonych w ubraniu specjalnym. Parametry badanego ratownika: wiek 36 lat, waga $92 \mathrm{~kg}$, wzrost $179 \mathrm{~cm}$. Obciążenie: szybki marsz $\mathrm{v}=7 \mathrm{~km} / \mathrm{h}$ poprzedzony okresem spoczynkowym $(4 \mathrm{~min})$

Źródło: Opracowanie własne.

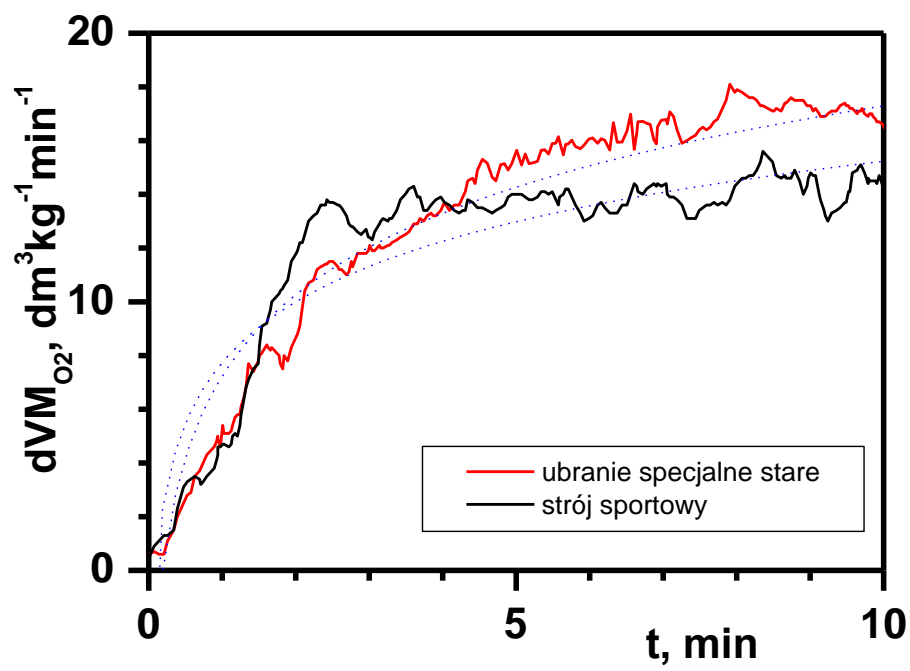

Ryc. 3. Przyrost wartości zużycia tlenu $\mathrm{dVM}_{\mathrm{O} 2}$ podczas pracy pod obciążeniem w ubraniu sportowym i specjalnym względem wartości przeciętnej stanu spoczynkowego. Parametry badanego ratownika: wiek 36 lat, waga $92 \mathrm{~kg}$, wzrost $179 \mathrm{~cm}$. Obciążenie: szybki marsz v =7 km/h. Źródło: Opracowanie własne. 


\section{Porównanie zużycia tlenu $\mathrm{VM}_{\mathrm{O} 2}$ dla ratownika będącego} $w$,tradycyjnym" ubraniu specjalnym oraz będącego w ubraniu specjalnym nowej generacji o maksymalnie obniżonej masie (USNG)

Przeciętna wartość zużycia tlenu dla osoby będącej w stanie spoczynku wynosiła odpowiednio $\mathrm{VM}_{\mathrm{O} 2 \mathrm{sr}}+/-\Delta \mathrm{VM}_{\mathrm{O} 2 \mathrm{sr} 1}=3,4+/-0,1 \mathrm{dm}^{3} \mathrm{~kg}^{-1} \mathrm{~min}^{-1}$ oraz $4,8+/-0,1 \mathrm{dm}^{3} \mathrm{~kg}^{-1} \mathrm{~min}^{-1}$ odpowiednio dla badań $\mathrm{w}$ „tradycyjnym” ubraniu specjalnym oraz USNG (ryc. 4, 6). Końcowy okres obciążenia charakteryzował się parametrami $\mathrm{VM}_{\mathrm{O} 2 \mathrm{sr} 2}+/-\Delta \mathrm{VM}_{\mathrm{O} 2 \mathrm{sr} 2}=20,8+/-0,3 \mathrm{dm}^{3} \mathrm{~kg}^{-1} \mathrm{~min}^{-1}$ (ubranie USNG) oraz $20,2+/-0,1 \mathrm{dm}^{3} \mathrm{~kg}^{-1} \mathrm{~min}^{-1}$ („tradycyjne” ubranie specjalne). Zatem różnica $\mathrm{VM}_{\mathrm{O} 2 \mathrm{sr} 2}-\mathrm{VM}_{\mathrm{O} 2 \text { sr1 }}$ wynosi odpowiednio: $16,0+/-0,4 \mathrm{dm}^{3} \mathrm{~kg}^{-1} \mathrm{~min}^{-1}$ (USNG) oraz $16,8+/-0,2 \mathrm{dm}^{3} \mathrm{~kg}^{-1} \mathrm{~min}^{-1}$ (ubranie specjalne). Otrzymany wynik wskazuje zatem, iż przeciętny przyrost zużycia tlenu w fazie końcowej obciążenia jest o 5\% wyższy dla „tradycyjnego ubrania” specjalnego.

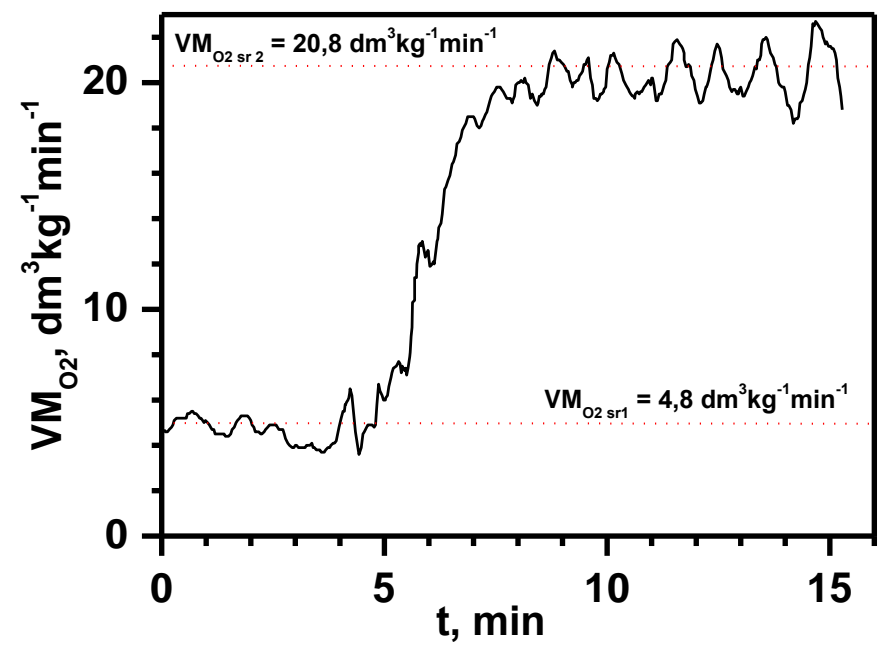

Ryc. 4. Zużycie tlenu $\mathrm{VM}_{\mathrm{O} 2}$ dla badań przeprowadzonych w ubraniu specjalnym nowej generacji o maksymalnie obniżonej masie (USNG). Parametry badanego ratownika: wiek lat 36, waga $92 \mathrm{~kg}$, wzrost $179 \mathrm{~cm}$. Obciążenie: szybki marsz v $=7 \mathrm{~km} / \mathrm{h}$.

Źródło: Opracowanie własne.

\section{Porównanie zużycia tlenu $\mathrm{VM}_{\mathrm{O} 2}$ dla ratownika będącego $w$,tradycyjnym" ubraniu specjalnym oraz będącego w ubraniu specjalnym przeznaczonym do działań w przestrzeni otwartej (USPO)}

Badania porównawcze pracy wykonywanej przez ratownika w „tradycyjnym” ubraniu specjalnym w stosunku do pracy w ubraniu USPO przeprowadzono według zmodyfikowanej metody obejmującej pomiar obciążenia na dwóch stanowiskach badawczych (drabina bez końca oraz cykloergometr) przy czasie obciążenia trwającym sześć minut w każdym przypadku. Celem dalszej dywersyfikacji danych 
doświadczalnych badaniu poddano młodego ratownika o następujących parametrach: wzrost $178 \mathrm{~cm}$, masa $75 \mathrm{~kg}$, wiek 22 lata.

Przeciętna wartość zużycia tlenu dla osoby będącej w stanie spoczynku wynosiła odpowiednio $\mathrm{VM}_{\mathrm{O} 2 \mathrm{sr} 1}+/-\Delta \mathrm{VM}_{\mathrm{O} 2 \mathrm{sr} 1}=5,0+/-0,1$ oraz $5,5+/-0,4 \mathrm{dm}^{3} \mathrm{~kg}^{-1} \mathrm{~min}^{-1}$ $\mathrm{dm}^{3} \mathrm{~kg}^{-1} \mathrm{~min}^{-1}$ odpowiednio dla badań $\mathrm{w}$ „tradycyjnym” ubraniu specjalnym oraz USPO (ryc. 5, 6). Końcowy okres obciążenia pierwszego etapu obciążenia (drabina bez końca) charakteryzował się parametrami $\mathrm{VM}_{\mathrm{O} 2 \mathrm{sr} 2}+/-\Delta \mathrm{VM}_{\mathrm{O} 2 \mathrm{sr} 2}=30,8+/-0,6$ $\mathrm{dm}^{3} \mathrm{~kg}^{-1} \mathrm{~min}^{-1}$ (USPO) oraz 33,8 +/- 0,6 $\mathrm{dm}^{3} \mathrm{~kg}^{-1} \mathrm{~min}^{-1}$ (ubranie specjalne tradycyjne). Końcowy okres obciążenia drugiego etapu obciążenia (cykloergometr) charakteryzował się parametrami $\mathrm{VM}_{\mathrm{O} 2 \mathrm{sr} 3}+/-\Delta \mathrm{VM}_{\mathrm{O} 2 \mathrm{sr} 3}=27,0+/-0,6 \mathrm{dm}^{3} \mathrm{~kg}$ ${ }^{-1} \mathrm{~min}^{-1}$ (USPO) oraz $28,2+/-0,2 \mathrm{dm}^{3} \mathrm{~kg}^{-1} \mathrm{~min}^{-1}$ (ubranie specjalne tradycyjne). Zatem różnica $\mathrm{VM}_{\mathrm{O} 2 \mathrm{sr} 2}-\mathrm{VM}_{\mathrm{O} 2 \mathrm{sr} 1}$ wynosi odpowiednio: $25,3+/-1,0 \mathrm{dm}^{3} \mathrm{~min}^{-1}$ (USPO) oraz $28,8+/-0,7 \mathrm{dm}^{3} \mathrm{~kg}^{-1} \mathrm{~min}^{-1}$ (tradycyjne ubranie specjalne) dla pierwszego etapu oraz $21,5+/-1,0 \mathrm{dm}^{3} \mathrm{~kg}^{-1} \mathrm{~min}^{-1}$ (USPO) i $23,2+/-0,3 \mathrm{dm}^{3} \mathrm{~kg}^{-1} \mathrm{~min}^{-1}$ (tradycyjne ubranie specjalne) dla drugiego etapu. Otrzymany wynik wskazuje zatem, iż przeciętny przyrost zużycia tlenu w fazie końcowej obciążenia jest o 12,2\% oraz $7,3 \%$ wyższy dla ubrania specjalnego tradycyjnego odpowiednio w pierwszej i drugiej fazie obciążenia pracą.

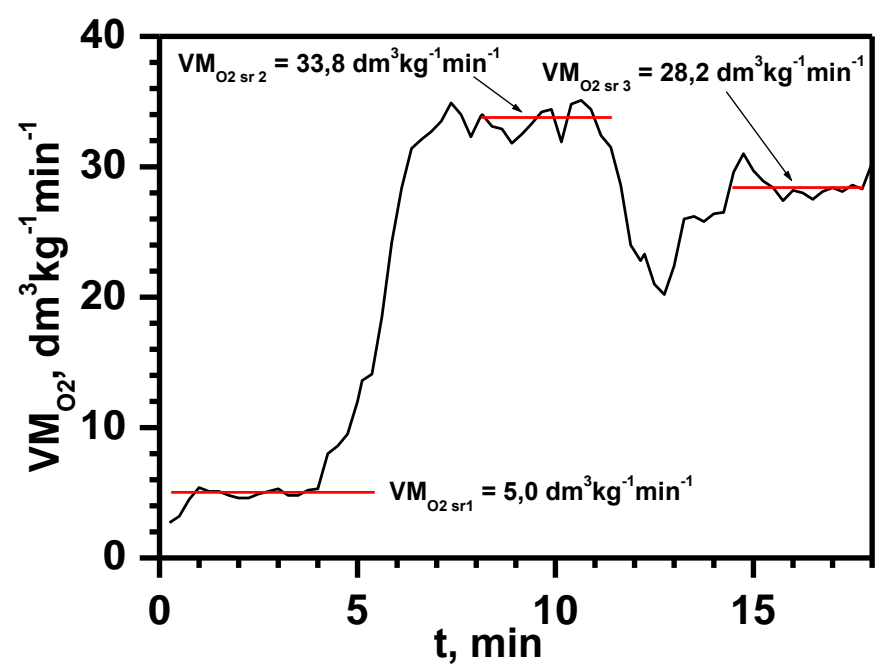

Ryc. 5. Zużycie tlenu $\mathrm{VM}_{\mathrm{O} 2}$ dla badań przeprowadzonych $\mathrm{w}$ „tradycyjnym” ubraniu specjalnym. Osoba badana: wiek 22 lata, masa $75 \mathrm{~kg}$, wzrost $178 \mathrm{~cm}$. Obciążenie: pierwszy etap obciążenia - drabina bez końca, drugi etap obciążenia - cykloergometr

Źródło: Opracowanie własne. 


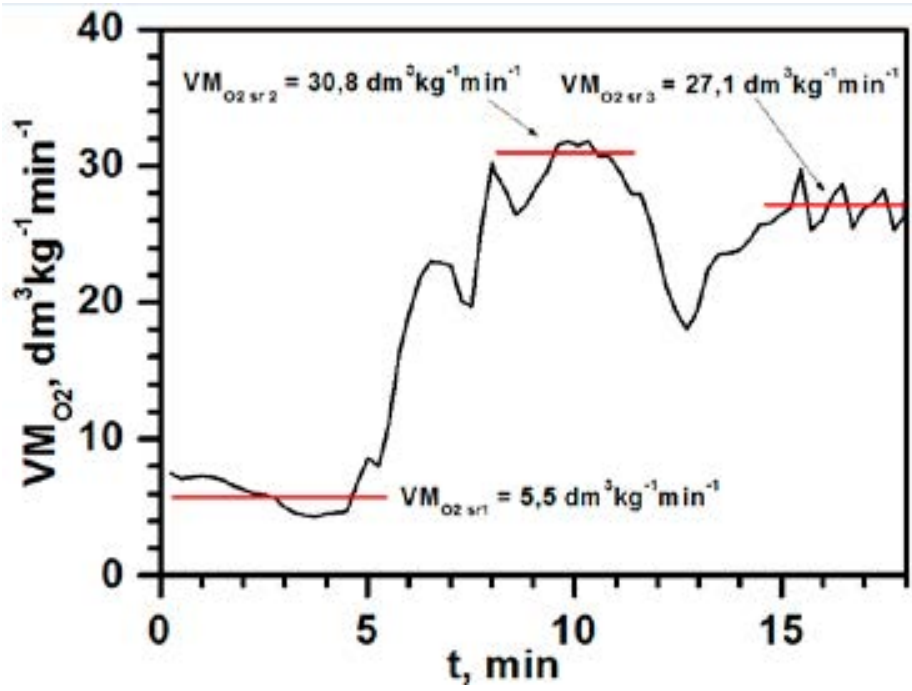

Ryc. 6. Zużycie tlenu $\mathrm{VM}_{\mathrm{O} 2}$ dla badań przeprowadzonych w ubraniu specjalnym nowej generacji przeznaczonego do działań w przestrzeni otwartej (USPO). Osoba badana: wiek 22 lata, masa $75 \mathrm{~kg}$, wzrost $178 \mathrm{~cm}$. Obciążenie: pierwszy etap obciążenia - drabina bez końca, drugi etap obciążenia - cykloergometr.

Źródło: Opracowanie własne.

\section{Wnioski}

Niezależnie od liczby przyjętych etapów oraz charakteru obciążenia (bieżnia, cykloergometr, drabina bez końca) we wszystkich przypadkach zaobserwowano, iż najwyższe zużycie tlenu $\mathrm{w}$ jednostce czasu $\mathrm{w}$ przeliczeniu na kilogram masy ciała obserwuje się dla "tradycyjnego" ubrania specjalnego. Najmniejsze różnice wynoszące 5\% wykazano dla badań porównawczych "tradycyjnego" ubrania specjalnego z USNG podczas badań obciążeniowych na bieżni $(\mathrm{v}=7 \mathrm{~km} / \mathrm{h})$. W przypadku badań porównawczych USPO zaobserwowano, iż przeciętny przyrost zużycia tlenu w fazie końcowej obciążenia jest o $12,2 \%$ oraz 7,3\% mniejszy niż dla „tradycyjnego” ubrania specjalnego odpowiednio w pierwszej (drabina bez końca) i drugiej fazie obciążenia pracą (cykloergometr).

Różnica zużycia tlenu przez ratownika będącego pod obciążeniem w tradycyjnym ubraniu specjalnym, a będącego w stroju sportowym (charakteryzującym przyjęty stan idealnego komfortu) wynosi $16,7 \%$. Zatem różnica pomiędzy zużyciem tlenu pod obciążeniem pomiędzy strojem sportowym a USNG wynosi 11,7\%. Obserwowane różnice dla ubrań spełniających rozporządzenie MSWiA z dnia 27 kwietnia 2010 r. wydają się być znaczne zwłaszcza, iż żaden z przedziałów ufności nie zazębiał się, a kryterium porównawcze w każdym z przypadków wykazało $\left|\mathrm{X}_{2}-\mathrm{X}_{1}\right|>\Delta \mathrm{X}_{1}+\Delta \mathrm{X}_{2}$. Tak więc wartości parametrów w „tradycyjnym” ubraniu 
specjalnym można uznać za istotnie wyższe od parametrów w stroju sportowym oraz w ubraniu USNG i USPO z prawdopodobieństwem równym $\mathrm{P}=90 \%$.

Wartość różnicy $\mathrm{VM}_{\mathrm{O} 2}$ pomiędzy strojem sportowym a nowoczesnym typem ubrania specjalnego (USNG) wskazuje na pewne pole manewru dla jeszcze nowszych technologii możliwych do zastosowania w przyszłości. Jest to bardzo istotne z punktu widzenia konieczności minimalizacji poziomu negatywnych bodźców związanych z obciążeniem pracą w ubraniu specjalnym przy jednoczesnym zachowaniu bezpieczeństwa prowadzenia działań ratowniczo-gaśniczych

Naukowcy z Indiana University Firefighter Health wskazują, iż zaledwie sam aspekt psychologiczny prowadzenia działań (np. przystąpienie do ataku na pożar) powoduje wzrost częstości skurczów serca (HR) do $71 \%$ osobniczego $\mathrm{HR}_{\max }$ oraz wzrost wentylacji minutowej płuc (VE) aż do $\sim 56 \mathrm{dm}^{3} / \mathrm{min}^{6}$. W badaniach porównawczych przy obciążeniu ratownika pracą, ale bez obciążenia stresorem niefizycznym tak wysokiej wartości nie otrzymano na żadnym z badanych przyrządów (bieżnia, cykloergometr, drabina bez końca) niezależnie od typu badanych ubrań. Przykładowy wykres prezentujący wentylację minutową płuc ratownika w ubraniu USNG podczas obciążenia pracą na drabinie bez końca oraz cykloergometrze przedstawiono na ryc. 7.

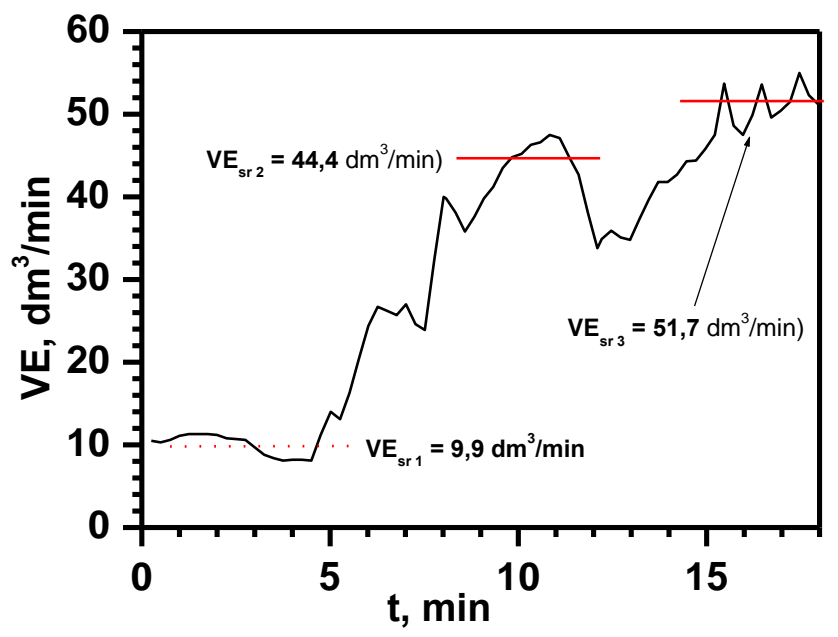

Ryc. 7. Wentylacja (VE) dla badań przeprowadzonych w tradycyjnym ubraniu specjalnym. Osoba badana: wiek 22 lata, masa $75 \mathrm{~kg}$, wzrost $178 \mathrm{~cm}$. Obciążenie: pierwszy etap obciążenia - drabina bez końca, drugi etap obciążenia - cykloergometr

Źródło: Opracowanie własne.

Zatem jakikolwiek dalszy wzrost dyskomfortu może doprowadzić do wzrostu zagrożenia związanego $\mathrm{z}$ niewydolnością pracy serca co potwierdziły badania naukowe przeprowadzone na ratownikach w USA z których wynikło, że niewydolność pracy serca jest przyczyną aż 44\% wypadków śmiertelnych?

6 Zob. Physiological Stress Associated, dz. cyt.

7 R.F. Fahy, dz. cyt.; U.S. Fire Administration, Firefighter fatalities in the United States in 2006, dz. cyt. 


\section{ZAKOŃCZENIE}

Publikacja jest próbą syntezy zagadnień z różnych dziedzin nauki, a także wiedzy praktycznej z obszaru zarządzania eksploatacją. Zawiera wnioski z dyskusji nad problemami użytkowania sprzętu i wyposażenia, w której wzięli udział reprezentanci różnych środowisk naukowych, organizacji i instytucji podczas konferencji pt. „Problemy monitoringu eksploatacji sprzętu i wyposażenia w straży pożarnej”, która odbyła się w dniach 26-27 marca 2015 r. Organizatorem konferencji było Centrum Naukowo-Badawcze Ochrony Przeciwpożarowej im. Józefa Tuliszkowskiego - Państwowy Instytut Badawczy w Józefowie.

Zjawiska eksploatacyjne są elementem każdego działania, a sprawna eksploatacja urządzeń wymaga od użytkowników przestrzegania pewnych reguł. Posiadanie właściwych kompetencji eksploatacyjnych jest szczególnie istotne w procesie tworzenia koncepcji, projektowania i produkcji wyrobów, gdy tworzy się ich własności eksploatacyjne na cały okres użytkowania, które można doskonalić tylko w ograniczonym zakresie w procesach innowacyjnych.

Badania problemów eksploatacji dotyczą rozwiązań teoretycznych i praktycznych, jak również źródeł oraz przyczyn powstawania zagrożeń, także tych nie zawsze pozostających w bezpośrednich związkach z efektywnością działań ratowniczo-gaśniczych. Konieczność prowadzenia badań w tym obszarze oraz edukacji środowiska zawodowego jest konsekwencją zmian zachodzących w obszarze wiedzy z zakresu bezpieczeństwa publicznego, szczególnie dla teoretyków i praktyków zajmujących się problematyką ratownictwa i ochrony ludności. 



\section{Bibliografia}

\section{Artykuły, opracowania zwarte:}

Apiecionek Ł., Czerniak J., Zarzycki H., Protection Tool for Distributed Denial of Services Attack, Beyond Databases, Architectures, and Structures Communications, "Computer and Information Science" 2014, 424, 405-414.

Apiecionek Ł., Romantowski M., Secure IP Network Model, "Computational Method in Science and Technology" 4 (2013), 209-213.

Apiecionek Ł., Romantowski M., Security solution for Cloud Computing, "Journal of Information, Control and Management Systems" 2 (2013), 51-61.

Apiecionek Ł., Romantowski M., Śliwa J., Jasiul B., Goniacz R., Safe Exchange of Information for Civil-Military Operations, MCC 2011: Military Communications and Information Systems Conference, Amsterdam, 17-18.10.2011, w: Military Communications and Information Technology: A Comprehensive Approach Enabler, M. Amanowicz (red.), Redakcja Wydawnictw Wojskowej Akademii Technicznej, Warszawa 2011, 39-50 (MK-312).

Bashkatov A.N., Genina E.A., Tuchin V.V., Optical properties of skin, subcutaneous, and muscle tissue: a review, "Journal of Innovative Optical Health Sciences" 1 (2011), 9-38.

Chitrphiromsri P., Kuznetsov A.V., Modeling heat and moisture transport in firefighter protective clothing during flash fire exposure, "Heat and Mass Transfer", 2005, 41, 206-215.

Chitrphiromsri P., Kuznetsov A.V., Song G., Barker R.L., Investigation offeasibility of developing intelligent firefighter-protective garments based on the utilization of a water-injection system, "Numerical Heat Transfer Part A", 2006, 49, 427-450.

Comer D., Sieci komputerowe: intersieci, WNT, Warszawa 2000.

Comer D.E., Sieci komputerowe TCP/IP. Zasady, protokoły i architektura, WNT, Warszawa 1997.

Czarnecka A., Dobrodziej C., Psychologiczne aspekty działań ratowniczych, ZWiS, Warszawa 2001.

Czerwienko D., Wykonanie sprawozdania z testów poligonowych w komorze rozgorzeniowej na SA PSP Kraków, Opracowanie wykonane w ramach projektu pt. „Nowoczesne ochrony osobiste służb ratowniczych KSRG w oparciu o potrzeby użytkowników końcowych”, finansowany przez NCBR, nr umowy projektu: 0014/R/ID1/2011/01, 27.03.2014 r.

Dmochowska A., Majder-Łopatka M., Jarosz W., Praca strażaka ratownika $w$ chemoodpornym ubraniu gazoszczelnym $w$ aspekcie fizycznego obciązenia organizmu, "Zeszyty Naukowe SGSP”, 46 (2013), 31-39.

Fahy R.F., U.S. firefighter fatalities due to sudden cardiac death, 1995-2004, Quincy, MA: National Fire Protection Association, 2005.

Fan J., Tsang H.W.K., Effect of clothing thermal properties on the thermal comfort sensation during active sports, “Textile Research Journal”, 78 (2), 2008, 111-118. 
Guidotti T.L., Human factors in firefighting: ergonomic, cardiopulmonary-, and psychogenic stress-related issues, "International Archive of Occupational and Environmental Health", 64 (1992), 1-12.

Guzewski P., Pawłowski R., Ranecki J., Ubrania ochrony przeciwchemicznej, SA PSP, wyd. I, Poznań 1997.

Hallberg B., Sieci komputerowe, kurs podstawowy, Edition2000, Kraków 2001.

Henriques F.C. Jr., Studies of Thermal Injury V. The Predictability and the Significance of Thermally Induced Rate Processes Leading to Irreversible Epidermal Injury, "Archives of Pathology", 1947, 43, s. 489-502.

Hunt C., TCP/IP - administracja sieci, Oficyna Wydawnicza Read Me, Warszawa 1996.

Kales S.N., Soteriades E.S., Christophi C.A., Christiani D.C., Emergency duties and deaths from heart disease among firefighters in the United States, "The New England Journal of Medicine”, 356 (2007), 1207-1215.

Keltner N.R., Evaluating Thermal Protective Performance Testing, "Journal of ASTM International", 5 (May 2005).

Kopaliński W., Słownik wyrazów obcych i zwrotów obcojęzycznych, Oficyna Wydawnicza Rytm, Warszawa 2014.

Kowalewski Z., Powodzie w Polsce - rodzaje, występowanie oraz system ochrony przed ich skutkami, Woda-Środowisko-Obszary Wiejskie, t. 6, z. 1 (16), 2006, s. 207-220.

Krause G., ABC dekontaminacji, „Przegląd Pożarniczy”, 11 (2006), 22.

Krucińska I., Konecki W., Michalak M., Systemy pomiarowe we włókiennictwie, Wyd. Politechniki Łódzkiej, Łódź 2006.

Kupicz W., Ogrodnik P., Moment obrotowy, godzinowe zużycie paliwa, oraz temperatura spalin jako parametry diagnostyczne silnika spalinowego o zapłonie samoczynnym pracujacego w warunkach stacjonarnych, „Zeszyty naukowe SGSP”, 44 (2012), 55-66.

Kupicz W., Ogrodnik P., Problemy eksploatacji pojazdów i sprzętu ratowniczo-gaśniczego w Państwowej Straży Pożarnej, „Logistyka”, 6 (2014).

Łapka P., Furmański P., Fixed Cartesian grid based numerical model for solidification process of semi-transparent materials I: modelling and verification, "International Journal of Heat and Mass Transfer”, 19-20 (September 2012), 4941-4952.

Łapka P., Furmański P., Fixed Cartesian grid based numerical model for solidification process of semi-transparent materials II: reflection and refraction or transmission of the thermal radiation at the solid-liquid interface, "International Journal of Heat and Mass Transfer", 19-20 (September 2012), 4953-4964.

Łazarkiewicz S., Troskolański A.T., Pompy wirowe, PWT, Warszawa 1959.

Legutko S., Eksploatacja maszyn, Wydawnictwo Politechniki Poznańskiej, Poznań 2007.

Lister T., Wright P.A., Chappell P.H., Optical properties of human skin, "Journal of Biomedical Optics" 9 (2012), s. 090901-1-15.

Malchaire J., Piette A., Kampmann B., Mehnert P., Gebhardt H., Havenith G., Den Hartog E., Holmer I., Parsons K., Alfano G., Griefahn B., Development and validation of the predicted heat strain model, "The Annals of Occupational Hygiene" 2 (2001), 123-135. 
Niziński S., Żurek J. Logistyka ogólna, Warszawa 2011.

Nowicki K., Woźniak J., Sieci LAN, MAN, WAN - protokoły komunikacyjne, Wydawnictwo Postępu Technicznego, Kraków 1998.

Pennes H.H., Analysis of tissue and arterial blood temperatures in the resting human forearm, "Journal of Applied Physiology" 2 (1948), 93-122.

Physiological Stress Associated with Structural Firefighting Observed in Professional Firefighters, Indiana University Firefighter Health \& Safety Research School of Health, Physical Education \& Recreation Department of Kinesiology Bloomington, Indiana, 2011.

Prasad K., Twilley W., Lawson J.R., Thermal Performance of Fire Fighters' Protective Clothing. 1. Numerical Study of Transient Heat and Water Vapor Transfer, NISTIR 6881, August 2002.

Riegert D., Doraźne metody ochrony przed powodzia, BiTP Vol. 35 Issue 3, 2014, pp. 139-147, DOI:10.12845/bitp.35.3.2014.13.

Riegert D. (red.), Doraźne metody ochrony stosowane podczas powodzi ze szczególnym uwzględnieniem rękawów przeciwpowodziowych, CNBOP-PIB, Józefów 2012.

Riegert D., Suchorab P., Istota dekontaminacji, materiały konferencyjne: IV Międzynarodowa Konferencja Naukowo-Techniczna nt. „Nowoczesne miasta. Infrastruktura i środowisko" INFRAEKO 2014.

Roguski J., Wróblewski D. i inni, Opracowanie metodologii stałego nadzoru eksploatacji wybranych obszarów wyposażenia Straży Pożarnej w zakresie niezawodności i skuteczności działania, [w:] Aktualne problemy bezpieczeństwa pożarowego, VNIIPO, Moskwa 2014, 501-504.

Roguski J., Wróblewski D., Majka A., Разработка современных учебных стендов для повышения эфбективности работ выполняемых работниками Национальной Системь Спасания и Тушения (KSRG), referat na XXIV międzynarodowej konferencji, Moskwa, 03-04.07.2012 r. (niepublikowany).

Song G., Barker R., Grimes D.R., Thompson D., Comparison of Methods Used to Predict the Burn Injuries in Tests of Thermal Protective Fabrics "Journal of ASTM International", 2 (February 2005).

Song G., Chitrphiromsri P., Ding D., Numerical simulations of heat and moisture transport in thermal protective clothing under flash fire conditions, "International Journal of Occupational Safety and Ergonomics" 1 (2008), 89-106.

Sothmann M.S., Saupe K., Jasenof D., Blaney J., Heart rate response of firefighters to actualemergencies; implications for cardiorespiratory fitness, "Journal of Occupational Medicine", 34 (1992), 797-800.

Stevens W.R., UNIX: programowanie ustug sieciowych, WNT, Warszawa 2002.

Stoll A., Chianta M.A., Method and Rating System for Evaluation of Thermal Protection, "Aerospace Medicine", 1969; 40, s. 1232-8.

Świderski A., Źródła stresu zawodowego, jego objawy i skutki ekonomiczne dla przedsiębiorstwa, Seminarium Okręgowego Inspektoratu Pracy w Łodzi „Stres w pracy”, 15 listopada 2006.

Szmelter W. (red.), Metrologia włókiennicza, t. IV, WNT, Warszawa 1972. 
Szylar J., Szkolenie Strażaków Ratowników OSP z zakresu działań przeciwpowodziowych oraz ratownictwa na wodach, CNBOP, Józefów 2009.

Verseeg H.K., Malalasekera W., An introduction to computational fluid dynamics. The finite volume method, Pearson Education, Harlow 2007.

Wang F., A Comparative Introduction on Sweating Thermal Manikin "Newton" and "Walter", 7th International Thermal Manikin and Modelling Meeting - University of Coimbra, September 2008.

Wawręty R., Żelaziński J., Zapory a powodzie, Wydawnictwo Towarzystwo na rzecz Ziemi, Polska Zielona Sieć, Oświęcim - Kraków 2006.

Zboina J., Pastuszka K., Znaczenie oceny zgodności dla ochrony przeciwpożarowej i ochrony ludności, BiTP Issue 4, 2012, pp. 87-95.

\section{Akty prawne:}

Rozporządzenie Ministra Spraw Wewnętrznych i Administracji z dnia 27 kwietnia 2010 r. zmieniającego rozporządzenie w sprawie wykazu wyrobów służących zapewnieniu bezpieczeństwa publicznego lub ochronie zdrowia i życia oraz mienia, a także zasad wydawania dopuszczenia tych wyrobów do użytkowania.

Rozporządzenie MSWiA z dnia 27 kwietnia 2010 r. w sprawie wykazu wyrobów służących zapewnieniu bezpieczeństwa publicznego lub ochronie zdrowia i życia oraz mienia, a także zasad wydawania dopuszczenia tych wyrobów do użytkowania (Dz. U. Nr 85, poz. 553).

Ustawa o ochronie przeciwpożarowej z dn. 24 sierpnia 1991 roku, Dz. U. z 1991 r. Nr 81, poz. 351.

Ustawa o Państwowej Straży Pożarnej z dn. 24 sierpnia 1991 roku, Dz. U. z 1991 r. Nr 88, poz. 400.

Ustawa o Zarządzaniu Kryzysowym z 8 kwietnia 2007 roku, Dz. U. z 2007 r. Nr 89, poz. 590.

Ustawa z dn. 8 listopada 1996 roku o zmianie ustawy o Państwowej Straży Pożarnej, Dz. U. z 1996 r. Nr 152, poz. 723.

\section{Inne dokumenty:}

ASTM F-1060, Standard Test Method for Thermal Protective Performance of Materials for Protective Clothing for Hot Surface Contact.

ASTM F-2731, Standard Test Method for Measuring the Transmitted and Stored Energy in Fire Fighter Protective Clothing Systems.

Baza danych KCKRiOL.

EN ISO 139: Textiles - Standard atmospheres for conditioning and testing (ISO 139:2005).

Gloger M., Rowicki Ł., Dwórska K., Badania ergonomiczności ubrań w testach poligonowych w SA PSP Kraków - po poprawkach konstrukcyjnych ubrań, wykonanie dokumentacji zdjecciowej i filmowej, Opracowanie wykonane w ramach projektu pt. „Nowoczesne ochrony osobiste służb ratowniczych KSRG w oparciu o potrzeby użytkowników końcowych", finansowanego przez NCBR, nr umowy projektu: 0014/R/ID1/2011/01, 08.12.2014 r. 
Gloger M., Rowicki Ł., Dwórska K., Przeprowadzenie testów poligonowych w SA PSP Kraków-część 2, wykonanie dokumentacji zdjęciowej i filmowej, Opracowanie wykonane w ramach projektu pt. „Nowoczesne ochrony osobiste służb ratowniczych KSRG w oparciu o potrzeby użytkowników końcowych", finansowanego przez NCBR, nr umowy projektu: 0014/R/ID1/2011/01, 27.09.2014 r.

Gloger M., Rowicki Ł., Dwórska K., Przeprowadzenie testów poligonowych w SA PSP Kraków - po poprawkach konstrukcyjnych ubrań, wykonanie dokumentacji zdjęciowej i filmowej na SA PSP Kraków, Opracowanie wykonane w ramach projektu pt. „Nowoczesne ochrony osobiste służb ratowniczych KSRG w oparciu o potrzeby użytkowników końcowych”, finansowanego przez NCBR, nr umowy projektu: 0014/R/ID1/2011/01, 08.12.2014 r.

Gloger M., Rowicki Ł., Lemańska K., Jurecki L., Przeprowadzenie testów poligonowych w komorze rozgorzeniowej na SA PSP Kraków, Opracowanie wykonane w ramach projektu pt. „Nowoczesne ochrony osobiste służb ratowniczych KSRG w oparciu o potrzeby użytkowników końcowych", finansowanego przez NCBR, nr umowy projektu: 0014/R/ ID1/2011/01, 27.03.2014 r.

Gloger M., Rowicki Ł., Lemańska K., Jurecki L., Wykonanie programu badań poligonowych na SA PSP Kraków, Opracowanie w ramach projektu pt. „Nowoczesne ochrony osobiste służb ratowniczych KSRG w oparciu o potrzeby użytkowników końcowych”, finansowanego przez NCBR, nr umowy projektu: 0014/R/ID1/2011/01, 27.12.2013 r.

Gloger M., Rowicki Ł., Lemańska K., Przeprowadzenie testów poligonowych w SA PSP Kraków - część 1, wykonanie dokumentacji zdjęciowej i filmowej, Opracowanie wykonane w ramach projektu pt. „Nowoczesne ochrony osobiste służb ratowniczych KSRG w oparciu o potrzeby użytkowników końcowych", finansowanego przez NCBR, nr umowy projektu: 0014/R/ID1/2011/01, 27.06.2014 r.

Instrukcja obsługi SVAN 979 „Miernik poziomu dźwięku, miernik drgań, analizator” SVANTEK Sp. z o.o., Warszawa, czerwiec 2013.

Instrukcja: „Stanowisko pomiarowe do badania i diagnozowania motopompy pożarniczej” ThermoLab S.C. Warszawa, sierpień 2014 r.

Karta katalogowa zbiornika zapasu wody produkcji firmy Dywit Sp. z o.o., Warszawa 2014.

Krucińska I., Skrzetuska E., Dokumentacja projektowa dotycząca badań ergonomiczności ubrania specjalnego nowej generacji o maksymalnie ograniczonej masie oraz ubrania specjalnego do działań ratowniczo-gaśniczych na przestrzeniach otwartych, niepublikowany, 2014.

Materiały projektu DOBR-BIO4/051/13087/2013 „Opracowanie metodologii stałego nadzoru eksploatacji wybranych obszarów wyposażenia straży pożarnej w zakresie niezawodności i skuteczności działania” finansowanego przez Narodowe Centrum Badań i Rozwoju.

NFPA 1971, Standard on Protective Ensembles for Structural Fire Fighting and Proximity Fire Fighting.

PN-EN 1486: Odzież ochronna dla strażaków. Metody badania i wymagania dla odzieży odbijajacej promieniowanie cieplne przeznaczonej do specjalnej akcji przeciwpożarowej (lipiec 2009). 
PN-EN 15614: Odzież ochronna dla strażaków. Metody badań laboratoryjnych oraz wymagania dla odzieży ochronnej używanej przy pożarach w przestrzeni otwartej (lipiec 2009).

PN-EN 367: Odzież ochronna. Ochrona przed ciepłem i płomieniem. Metoda wyznaczania przenikania ciepła przy działaniu płomienia (styczeń 1996).

PN-EN 702: Odzież ochronna. Ochrona przed goracem i płomieniem. Metoda badania: Wyznaczanie przenikania ciepła kontaktowego przez odzież ochronna lub materiały na nia przeznaczone (marzec 2002).

Salomonowicz Z., Naworol I., Zebranie literatury i sprecyzowanie założeń kierunku prowadzenia dekontaminacji wewnętrznej i zewnętrznej rękawów, Sprawozdanie z realizacji projektu „Optymalizacja procedur, dyslokacji baz i doskonalenie rozwiązań technicznych sprzętu stosowanego przez polskie służby ratownicze w zakresie przeciwdziałania zagrożeniom naturalnym ze szczególnym uwzględnieniem powodzi (rękawy przeciwpowodziowe)", Warszawa 2012.

Sprawozdanie częściowe z zadania badawczego 15011210 projektu „Monitoring” - Identyfikacja i rozpoznanie możliwych do wykorzystania środków transmisyjnych.

Sprawozdanie częściowe z zadania badawczego 15011210 projektu „Monitoring” - Eksperymenty badawcze nowych technologii.

Sprawozdanie częściowe z zadania badawczego 15011210 projektu „Monitoring” - Analiza protokołów wymiany danych na łączach radiowych.

Sprawozdanie z warsztatów łączności i informatyki ASTER’08, TELDAT.

Thermal Manikin Newton, Manual, 2010.

U.S. Fire Administration, Firefighter fatalities in the United States in 2005, Emmitsburg, MD, 2006.

U.S. Fire Administration, Firefighter fatalities in the United States in 2006, Emmitsburg, $\mathrm{MD}, 2006$.

Wniosek DOBR-BIO4/051/13087/2013.

Wniosek nr 13087 „Monitoring”.

Zasady wyposażania $i$ wykorzystania komór dymowych w Państwowej Straży Pożarnej, Komenda Główna Państwowej Straży Pożarnej, Warszawa 2013

\section{Strony internetowe:}

http://www.analog.com/en/design-center/reference-designs/hardware-reference-design/ circuits-from-the-lab/CN0287.html.

www.kgpsp.gov.pl

http://elinux.org/Beagleboard:BeagleBoneBlack.

http://www.a123systems.com/Cycle-Life-Testing-The-Lithium-Ion-Battery-Ultramarathon. htm.

http://www.analog.com/en/design-center/reference-designs/hardware-reference-design/ circuits-from-the-lab/CN0209.htm.

http://motofocus.pl/technika/10389/pompy-wody-w-napedach-rozrzadu-problemy-czesc-1 http://rejestrowanie-multimediow.eprace.edu.pl/135,Protokol_TCP.html 
http://swiatlan.pl/protokoly/protokol-ip.html

http://technet.microsoft.com/pl-pl/library/cc785220(v=ws.10).aspx

http://www.straz.gov.pl/data/newsFiles/skulich.pdf

http://www.straz.gov.pl/data/other/biuletyn2012.pdf

http://www.straz.gov.pl/data/other/nowy_2.pdf

https://www.msw.gov.pl/pl/bezpieczenstwo/ochrona-ludnosci/8758,Ochotnicze-Straze-Pozarne.html

https://www.sgsp.edu.pl/uczelnia/kdrg/zrch/cw/dekon_sorb.pdf 



\title{
Abstrakty
}

\section{Część I \\ Nadzór nad eksploatacją wybranych obszarów wyposażenia straży pożarnej w zakresie niezawodności i skuteczności działania}

\section{Metodyka i kryteria wyboru obiektów do badań}

\author{
Dariusz Czerwienko, Leszek Jurecki, Jacek Roguski
}

„Opracowanie metodologii stałego nadzoru eksploatacji wybranych obszarów wyposażenia straży pożarnej w zakresie niezawodności i skuteczności działania” zakłada osiągnięcie efektu końcowego, którym będzie system informatyczny pozwalający określić istotne z punktu widzenia eksploatacji parametry wyposażenia, opracować metody doskonalenia tych parametrów w celu poprawy bezpieczeństwa ratownika i skuteczności prowadzonych działań oraz monitorowanie bieżącego zużycia sprzętu. Dla uzyskania zamierzonego efektu należy przeprowadzić szereg działań badawczych, które pozwolą na przyjęcie uzasadnionego kierunku działań realizowanych przez konsorcjantów realizujących projekt. Konsorcjum ma za zadanie stworzyć jako wynik projektu demonstrator technologii, unikalny na skalę europejską system nadzoru i kontroli nad wyposażeniem technicznym stosowanym w straży pożarnej.

Zadania badawcze realizowane przez CNBOP-PIB dotyczą pozyskania danych statystycznych $z$ wykorzystaniem istniejących baz danych oraz własnych opracowań. Przeprowadzono analizę stosowanych rozwiązań technicznych w zakresie sprzętu stosowanego w ochronie przeciwpożarowej na podstawie istniejących baz danych ze szczególnym uwzględnieniem pojazdów, motopomp, autopomp i armatury wodno-pianowej i narzędzi hydraulicznych. Na podstawie opracowanej identyfikacji działań przeprowadzone zostaną ustalenia dotyczące: 1. najbardziej zawodnego sprzętu; 2 . występujących rodzajów uszkodzeń; 3. średniego czasu pomiędzy uszkodzeniami; 4. intensywności użytkowania wybranego sprzętu; 5. współczynnika gotowości wytypowanego sprzętu.

Powyższe dane oraz analiza parametrów pracy jest podstawą do wytypowania istotnych parametrów diagnostycznych wybranego sprzętu pożarniczego. Tworzone Lokalne Środowisko Badawcze umożliwi badania przyśpieszonego starzenia, a dzięki budowie odpowiedniego oprogramowania do zbierania i przetwarzania danych będzie możliwe ich dalsze przekazywanie do systemu.

Przeprowadzenie badań według opracowanych procedur i programów na stanowiskach wykonanych zgodnie z wytworzoną dokumentacją pozwoli na:

1. Opracowanie algorytmów diagnozowania, prognozowania i generowania (oceny) stanu technicznego wybranego sprzętu pożarniczego;

2. Wypracowanie rekomendacji do nowelizacji wymagań techniczno-użytkowych wyposażenia straży pożarnej oraz wytycznych dla producentów w zakresie poprawy funkcjonalności i niezawodności wybranych grup sprzętowych. 


\title{
Wymagania funkcjonalne dla systemu monitorowania i analiza niezawodności eksploatacji wybranych środków wyposażenia Państwowej Straży Pożarnej
}

\author{
Janusz Kręcikij, Dawid Rzemek
}

Informatyzacja i automatyzacja procesów w XXI wieku występuje w każdej dziedzinie nauki. Obecnie mamy do czynienia z ciągłym dążeniem do zwiększania efektywności pracy jednostek ludzkich. Państwowa Straż Pożarna jako jeden z podmiotów, który stanowi element zapewnienia bezpieczeństwa obywatelowi w sytuacjach nagłych i kryzysowych, musi szybko reagować na zgłoszenia i być w pełnej gotowości do działania. W czynnościach ratowniczo-gaśniczych nie wszystko zależy tylko i wyłącznie od efektywności czynnika ludzkiego. W codziennej pracy ogół niezawodności i gotowości do działania stanowią narzędzia i odpowiednio przygotowany sprzęt. Z myślą o zapewnieniu ciągłości pracy, automatyzacji przy dostarczaniu i analizie danych operacyjno-logistycznych, przekazywaniu w czasie rzeczywistym niezbędnych informacji o jednostkach sprzętowych dla każdego z poziomów struktury PSP powstała koncepcja Systemu Monitorowania Stanu Technicznego. Na potrzeby stworzenia zarysu SMST zostały przeanalizowane regulaminy, instrukcje, rozporządzenia, decyzje i efekty prac naukowo-badawczych związanych z monitorowaniem stanu ilościowego i technicznego sprzętu. System ma zostać wdrożony i będzie eksploatowany na różnych poziomach Państwowej Straży Pożarnej takich jak: Komenda Główna PSP, komendy wojewódzkie PSP, komendy powiatowe i miejskie PSP, jednostki ratowniczo-gaśnicze (w tym JRG ośrodków szkoleniowych). Na każdym z wymienionych szczebli system będzie posiadał możliwość opisowego i graficznego dostarczania zinterpretowanych danych przez sensory z jednostek sprzętowych (JS) dla osób logistycznych (OL) i osób operacyjnych (OO). Do kluczowych zagadnień ma należeć możliwość prowadzenia analiz i uogólnień co do potrzeb i stopnia wykorzystywania poszczególnych jednostek sprzętowych w czasie i przestrzeni. System ma dostarczać także dowódcy akcji ratowniczo-gaśniczej informacje niezbędne do podejmowania decyzji o jednostkach sprzętowych w czasie rzeczywistym, w miejscu prowadzenia działań ratowniczych, za pośrednictwem urządzenia mobilnego. Głównym założeniem tego rozwiązania jest dostarczanie jedynie syntetycznych danych do dowódcy akcji ratowniczo-gaśniczych. Dowódca będzie otrzymywał informacje o położeniu jednostek sprzętowych na mapie $2 \mathrm{D}$ oraz o ich stanie technicznym. Innowacyjna koncepcja SMST jest niezwykle cenna dla całokształtu funkcjonowania PSP - pozwala ona na wykorzystanie całego potencjału każdej jednostki ratowniczo-gaśniczej. Przewagą koncepcji systemu monitorowania nad dotychczasowymi rozwiązaniami systemowymi jest brak konieczności angażowania pracowników do ręcznego analizowania danych na temat parametrów wykorzystywanego sprzętu. Informacje te są automatycznie eksportowane przez sensory i importowane do bazy danych systemu monitoringu z możliwością dostarczenia zinterpretowanych raportów w czasie rzeczywistym do osób uprawnionych. 


\title{
Bezpieczeństwo transmisji danych w systemach monitorowania wyposażenia straży pożarnej
}

\author{
Łukasz Apiecionek, Rafał Motylewski, Paweł Stosik
}

Celem niniejszego artykułu jest znalezienie odpowiedzi na pytanie, jak powinien wyglądać system łączności pod względem bezpieczeństwa samego medium transmisyjnego, które może zostać poddane różnorakim atakom przez osoby nieuprawnione do dostępu do danych przechowywanych przez system.

Każdy system monitorowania wymaga systemu łączności. W zależności od jego architektury, może się on jednak stać słabym ogniwem pod względem bezpieczeństwa. Ataki typu Distributed Denial of Service mogą unieruchomić cały system i zablokować działania serwerów na wiele godzin. Efektem tego może być zmniejszenie możliwości skutecznego działania straży pożarnej, co istotnie zwiększa prawdopodobieństwo wzrostu strat spowodowanych przez zdarzenia niepożądane. Wprowadzenie mechanizmów bezpieczeństwa jest więc konieczne i korzystne. Z tego też względu wskazane jest: bezwzględne stosowanie kontroli użytkowników, którzy mają dostęp do systemu; wyposażanie serwerów w odpowiednie mechanizmy logowania zdarzeń, tak aby administrator miał możliwość odtworzenia działania systemu i zadań wykonywanych przez użytkowników w momencie ataku; - poddawanie przesyłanych danych kodowaniu; uwierzytelnianie nie tylko użytkowników, ale również elementów systemu, co jest spowodowane koniecznością wyeliminowania sytuacji umożliwiającej hakerowi dokonanie podmiany urządzenia/ urządzeń na swoje. W celu prawidłowej realizacji powyższego jako zasadę powinno się przyjąć, aby zagadnienia bezpieczeństwa poddawać analizie w trakcie projektowania systemu. Odpowiednie cechy jego działania kształtuje się bowiem już na etapie realizacji tego procesu. Przydatne w tym przedmiocie mogą być wytyczne dla systemów przetwarzających informacje niejawne, publikowane przez Agencję Bezpieczeństwa Wewnętrznego. Stanowią one bowiem dobre praktyki budowania bezpiecznych architektur w tym zakresie. Nawet w systemach, które nie przetwarzają informacji niejawnych, warto zachować odpowiednie poziomy bezpieczeństwa i pamiętać również o odpowiednich zasadach przechowywania danych.

W artykule wykorzystano metodę analizy krytycznej, aby rozważyć zagadnienia zabezpieczenia systemu przy jednoczesnym umożliwieniu jego szybkiego i skutecznego działania.

Wykonana analiza wykazała, że czasem należy zrezygnować z największych możliwych zabezpieczeń na rzecz użyteczności systemu. Wprowadzone mechanizmy bezpieczeństwa nie mogą spowalniać pracy, czy jej wręcz uniemożliwiać lub czynić projekt nieopłacalnym. Dlatego zawsze należy rozważyć możliwość osiągnięcia celu w aspekcie poniesionych kosztów, zwłaszcza niezasadnego ich zawyżania. Wprowadzenie możliwie trudnych do złamania mechanizmów może rozbudować system pod względem: wymiarów urządzeń, kosztów wykonania, czy poboru energii. Dlatego w projektowanym systemie zaleca się zastosowanie racjonalnego techniczno-ekonomicznego podejścia do zagadnienia bezpieczeństwa. 


\title{
Sieć sensorowa systemu pomiaru i diagnozowania pomp stosowanych w jednostkach ratowniczo-gaśniczych
}

\author{
Mikołaj Sobczak, Michał Pasieka, Bartosz Kukawka \\ Celem artykułu jest prezentacja części tworzonego projektu demonstratora systemu \\ umożliwiającego stały nadzór eksploatacyjny wybranego wyposażenia straży pożarnej \\ w zakresie niezawodności i skuteczności działania. \\ Projekt „Opracowanie metodologii stałego nadzoru eksploatacji wybranych obszarów \\ wyposażenia straży pożarnej w zakresie niezawodności i skuteczności działania” jest re- \\ alizowany w ramach projektu rozwojowego nr DOBR-BIO4/051/13087/2013. Na podsta- \\ wie wymagań dotyczących metodologii diagnostyki wybranego sprzętu straży pożarnej, \\ wykonanej w ramach projektu przez konsorcjum, został opracowany system spełniający \\ wymagane parametry i funkcje. Wszystkie rozwiązania zostały zaprojektowane i wybrane \\ przez specjalistów praktyków tak, by uzyskać nowoczesny i trwały system umożliwiający \\ dalszy rozwój.
}

Technologią, która została opracowana, jest modułowy bezprzewodowy system monitoringu sprzętu straży pożarnej dedykowany dla autopomp, motopomp, pomp sprzętu hydraulicznego. W artykule przedstawiono dotychczasowe prace nad projektem. Opisane zostały elementy składowe systemu i oprogramowania, a w szczególności projektowane elementy stanowiące część sprzętową. Określona została architektura systemu oraz konkretne rozwiązania sprzętowe realizujące wymagane zadania takie jak dokonywanie pomiarów z czujników zainstalowanych na pompie, akwizycja i interpretacja zebranych danych, sygnalizacja stanu pracy, przekazywanie informacji o pracy urządzenia do pozostałych elementów systemu oraz dostarczanie i zarządzanie energią dla poszczególnych modułów systemu.

Dzięki prezentowanemu systemowi możliwe będzie wykrywanie lub zapobieganie awarii sprzętu, od którego niezawodności zależy powodzenie akcji ratowniczej. System projektowany jest pod kątem modułowości i uniwersalności, dzięki czemu możliwy jest dalszy rozwój projektu i wykorzystanie go do diagnozowania innego wyposażenia straży np. układu napędowego samochodów strażackich. Całość będzie nadzorowana przez oprogramowanie umożliwiające wizualizacje wybranych danych oraz zarządzanie systemem. Dostęp do systemu możliwy będzie na różnych poziomach dowodzenia zarówno z konsol stacjonarnych, jak i urządzeń mobilnych stosowanych na miejscu akcji.

\section{Badanie wpływu wybranych uszkodzeń na parametry pracy motopompy pożarniczej - wyznaczenie wartości parametrów dla stanu zdatności}

Włodzimierz Kupicz, Paweł Ogrodnik

Celem artykułu było zaprezentowanie wyników badań doświadczalnych wpływu wybranych symulowanych uszkodzeń na wartość parametrów diagnostycznych motopompy pożarniczej OTTER 6/6. Uzyskane wyniki badań będą podstawą do wytypowania istotnych parametrów diagnostycznych wybranego sprzętu pożarniczego. Badania zostały przeprowadzone $\mathrm{w}$ ramach projektu rozwojowego w obszarze obronności nr 
DOBR-BIO4/051/13087/2013 „Opracowanie metodologii stałego nadzoru eksploatacji wybranych obszarów wyposażenia straży pożarnej w zakresie niezawodności i skuteczności działania".

W ramach zadania opracowano wstępną koncepcję metody badań na podstawie, której określono parametry diagnostyczne, dane dotyczące niezbędnych czujników oraz algorytmy diagnozowania. Kolejnym etapem było opracowanie koncepcji stanowiska badawczego gwarantującego wykonanie badań w zakresie utworzonej metody. Niezbędne było również wykonanie projektu technicznego stanowiska i dobór odpowiedniej aparatury kontrolno-pomiarowej. Jednym z podstawowych elementów stanowiska pomiarowego jest zbiornik wraz z instalacja wodną. Konstrukcję zbiornika wykonano z blach stalowych ocynkowanych, ze stali S350GD, a sam zbiornik ma objętość $V=4,5 \mathrm{~m}^{3}$. Stanowisko pomiarowe wyposażono w motopompę OTTER, która została wyposażona w czujniki pomiarowe. W sumie stanowisko zostało wyposażone w 13 kanałów pomiarowych (z możliwością ich zwiększenia). Układ rejestracji sygnałów został wyposażony w dwa rejestratory sygnałów wolno- i szybkozmiennych. Specjalnie do celów projektowych zostało opracowane oprogramowanie pozwalające na monitoring mierzonych parametrów. Stanowisko wyposażone zostało również w miernik poziomu dźwięku SVAN 979 firmy SVANTEK. Po wykonaniu stanowiska opracowano końcową metodykę badań. Badania zostały podzielone na dwie części - na badania wstępne oraz zasadnicze.

W czasie badań wyznaczono zbiór parametrów diagnostycznych agregatu, którym jest motopompa pożarnicza. Dla części silnikowej jest to prędkość obrotowa wału korbowego, temperatury spalin na poszczególnych cylindrach, zużycia paliwa, temperatura oleju silnikowego. W przypadku części pompy: ciśnienie ssania, ciśnienie tłoczenia intensywność przepływu wody, temperatury wody po stronie ssawnej i tłocznej, temperatura wody w kadłubie pompy. Dodatkowo podczas badań monitorowane były warunki otoczenia: temperatura powietrza i ciśnienie atmosferyczne.

Podczas prac trwających w ramach pierwszego etapu badań wyznaczono charakterystyki parametrów diagnostycznych pompy dla stanu zdatnego w warunkach atmosferycznych zbliżonych do normalnych. Dla wyznaczenia powtarzalności sygnałów przeprowadzono 85 pomiarów w 8 seriach, przy parametrach odpowiadających nominalnym warunkom pracy pompy (6 bar, 500 l/min). Zaproponowane parametry diagnostyczne w stałych warunkach badań charakteryzują się dużą powtarzalnością. Na podstawie zarejestrowanych pomiarów wytypowano warunki, w których powinny odbywać się pomiary służące jako podstawa diagnozowania motopompy.

\section{Eksploatacja rękawów przeciwpowodziowych}

\section{Dorota Riegert, Zuzanna Ślosorz, Adam Majka}

Zmiany klimatu powodują coraz częstsze występowanie klęsk żywiołowych w postaci powodzi, które stwarzają dużo strat materialnych i niematerialnych. Służby ratownicze podczas prowadzonych akcji używają różnego rodzaju sprzętu, w tym między innymi rękawów przeciwpowodziowych, które służą do zabezpieczania terenów zagrożonych przed zalaniem. W artykule została przedstawiona problematyka związana z eksploatacją rękawów przeciwpowodziowych, to jest z ich użytkowaniem, dekontaminacją oraz recyklingiem. 


\title{
Część II
}

\section{Nowoczesne rozwiązania ochron osobistych dla służb ratowniczych KSRG w oparciu o potrzeby użytkowników końcowych}

\section{Problemy związane z oceną ochron osobistych poddanych obciążeniu cieplnemu}

\author{
Tomasz Wiśniewski, Piotr Furmański, Piotr Łapka
}

W artykule dokonano przeglądu polskich i wybranych zagranicznych norm dotyczących metod badania odzieży ochronnej strażaków poddanej oddziaływaniu płomienia, promieniowania cieplnego i ciepła kontaktowego. Scharakteryzowano metody pomiarowe i wskaźniki użyte do oceny odzieży pod względem ochrony przed poparzeniem. Omówiono wady stosowanych metod i procedur pomiarowych. Zaproponowano modyfikacje metod pomiarowych.

Scharakteryzowano procesy wymiany ciepła i wilgoci w ubraniach strażackich i podano równania, które je opisują. Omówiono model matematyczny zastosowany do modelowania numerycznego transportu ciepła i wilgoci w ochronach osobistych strażaków. Podano przykładowe dane dotyczące odzieży i skóry człowieka, niezbędne do przeprowadzenia obliczeń.

Zaprezentowano przykładowe wyniki symulacji numerycznej transportu ciepła i wilgoci w odzieży ochronnej oraz oceniono skalę oparzeń. Jako kryterium oceny zastosowano całkę Henriquesa.

Zamieszczono wnioski odnoszące się do sposobu oceny ochron osobistych strażaków. Zaproponowano modyfikację metod pomiarowych, zwłaszcza wykorzystanie całki Henriquesa jako kryterium oceny. Wskazano na konieczność badań zawilgoconych próbek odzieży ochronnej oraz jej pojemności cieplnej. Wskazano na możliwość wykorzystania symulacji numerycznych do oceny skuteczności ochron osobistych. Wymaga ona m.in. znajomości właściwości radiacyjnych poszczególnych warstw odzieży.

\section{Badania ergonomiczne odzieży ochronnej z zastosowaniem manekina typu Newton}

Izabella Krucińska, Ewa Skrzetuska

Celem pracy było dokonanie oceny wybranych właściwości biofizycznych decydujących o ergonomii odzieży ochronnej dla służb ratowniczych KSRG opracowanej w wyniku realizacji projektu „Nowoczesne ochrony osobiste służb ratowniczych KSRG w oparciu o potrzeby użytkowników końcowych” o akronimie FIREGUARD. 2015.

Badania przeprowadzono na manekinie termicznym typu Newton firmy MTNW będącym w posiadaniu laboratorium akredytowanego Lab-Tex, mieszczącego się w Katedrze Materiałoznawstwa, Towaroznawstwa i Metrologii Włókienniczej Politechniki Łódzkiej zgodnie z normą PN-EN ISO 15831:2006 i PN-EN 342:2006.

W opracowaniu przedstawiono wyniki badań izolacyjności cieplnej dla zestawów odzieży strażackiej wytworzonej specjalnie na potrzeby projektu FIREGUARD 2015, 
w założonych warunkach klimatycznych (temp. $-20^{\circ} \mathrm{C} \div+20^{\circ} \mathrm{C}$ ) i dla dwóch różnych rodzajów bielizny.

Przeprowadzono analizę wyników badań izolacyjności cieplnej dwóch zestawów odzieży ochronnej dla służb ratowniczych KSRG w odniesieniu do normy PN-EN 342:2006 Odzież ochronna - Zestawy odzieży i wyroby odzieżowe chroniace przed zimnem. Zaobserwowano, że wraz z obniżaniem temperatury otoczenia obniża się efektywna izolacyjność cieplna. Jeden $\mathrm{z}$ wariantów wytworzonej odzieży posiadający w swoim składzie warstwę izolującą spełnia wymagania ochronne przed nadmierną utratą ciepła użytkowników w warunkach pracy zdefiniowanych w normie PN-EN 342:2006. Odzież ta zabezpiecza użytkownika przed zaburzeniem bilansu cieplnego w warunkach pracy stojącej o niskim wydatku energetycznym wynoszącym $75 \mathrm{~W} / \mathrm{m}^{2}$. Pracownik noszący taką odzież może pracować przez osiem godzin w temperaturze $11^{\circ} \mathrm{C}$ lub 1 godzinę $\mathrm{w}$ temperaturze $-2^{\circ} \mathrm{C}$ zarówno przy stosowaniu bielizny letniej, jak i zimowej.

\title{
Badania eksploatacyjne w polu operacyjnym
}

\author{
Łukasz Pastuszka, Karolina Dwórska, Łukasz Rowicki, Maciej Gloger
}

Założeniem projektu rozwojowego nr 0014/R/ID1/2011/01 „Nowoczesne ochrony osobiste służb ratowniczych KSRG w oparciu o potrzeby użytkowników końcowych" finansowanego przez NCBR jest zastosowanie najnowszych osiągnięć technologii tekstylnych umożliwiających spełnienie rosnących wymagań stawianych kompleksowym ochronom osobistym. Założono położenie szczególnego akcentu na wymagania odporności i optymalizowanej skuteczności ochrony przed zagrożeniami podczas działań ratowniczo-gaśniczych przy zachowaniu pełnego komfortu pracy ratownika. W ramach projektu wypracowano strukturę produktów obejmującą między innymi istotne we współczesnych uwarunkowaniach elementy: ubranie strażackie o maksymalnie ograniczonej masie oraz ubranie strażackie do działań ratowniczo-gaśniczych na przestrzeniach otwartych.

$\mathrm{W}$ projekcie stworzono narzędzie umożliwiające $\mathrm{w}$ warunkach rzeczywistych weryfikację ergonomiczności odzieży strażackiej oraz przeprowadzenie badań psychomotorycznych ratowników, którego działanie opiera się na elektronicznym systemie złożonym z jednostki centralnej, przekaźników radiowych oraz tzw. ubrania „inteligentnego” (typu „smart”), wyposażonego w urządzenia elektroniczne umożliwiające zdalne pomiary parametrów środowiskowych oraz fizjologicznych. Ćwiczebny system zintegrowany został opracowany do realizacji funkcji automatycznej: oceny poziomu zmęczenia strażaka (wykrywanie stanu zagrożenia dla zdrowia), analizy wydolności organizmu (test wysiłkowy), lokalizacji strażaka na poligonie i w komorze testowej, analizy parametrów odzieży, oceny komfortu odzieży ochronnej.

Ćwiczebny system niezależny posiada analogiczne funkcje monitorowania parametrów ratowników do systemu zintegrowanego. Różnica polega na umieszczeniu układów pomiarowych w specjalnie zaprojektowanym podkoszulku zamiast w kurtce. Dzięki temu system umożliwia prowadzenie pomiarów parametrów fizjologicznych ratowników wykorzystujących podczas ćwiczeń różne ubrania wierzchnie. Rozwiązanie to pozwala na porównywanie komfortu zapewnianego przez ubrania strażackie różnych konstrukcji. System niezależny może być stosowany wraz z dowolnym ubraniem wierzchnim, do którego od zewnątrz dołączony zostanie moduł osobisty. 
Otrzymane wyniki oraz analiza parametrów pracy ratownika jest podstawą do stworzenia systemu diagnostycznego. Powstałe Lokalne Środowisko Badawcze umożliwi badania ergonomiczne, a dzięki budowie odpowiedniego oprogramowania umożliwi ocenę stanu zdrowia funkcjonariuszy.

Przeprowadzenie badań według opracowanych procedur i programów pozwoli na:

1. Wdrożenie do produkcji nowych produktów: ubrania strażackiego o maksymalnie ograniczonej masie oraz ubrania strażackiego do działań ratowniczo-gaśniczych na przestrzeniach otwartych.

2. Wypracowanie rekomendacji do nowelizacji wymagań techniczno-użytkowych wyposażenia straży pożarnej oraz wytycznych dla producentów ubrań strażackich w zakresie poprawy ich funkcjonalności.

\section{Wpływ konstrukcji ubrań specjalnych na parametry wydolnościowe ratownika}

Tomasz Węsierski, Przemysław Kowalczyk

Praca ratownika w strefie zagrożenia wiąże się z dużym temperaturowym dyskomfortem fizycznym. Wpływa to na wydajność jego pracy, obniża szybkość i dokładność wykonywanych zadań oraz zdolność do podejmowania decyzji. Nie jest to bez znaczenia podczas długotrwałych działań ratowniczo-gaśniczych, zwłaszcza w warunkach dużych obciążeń termicznych. W warunkach działań ratowniczych zapewnienie komfortu psychofizycznego ratownikowi jest trudne, ale możliwe przy pomocy profesjonalnego wyposażenia, które pozwala na prowadzenie działań z dystansu, czy też dzięki jego automatyzacji, lub choćby przez dobór właściwych parametrów wydajności armatury pożarniczej. Nie wszystkie działania da się jednak wykonać zdalnie i konieczne jest wejście ratownika w rejon wysokiego poziomu zagrożenia. Stąd też konstrukcja ubrań specjalnych przechodzi ciągłą ewolucję celem poprawy bezpieczeństwa oraz komfortu pracy ratownika w czasie działań ratowniczo-gaśniczych. Realizacja tego zadania odbywa się choćby poprzez zmniejszenie wagi ubrania specjalnego, stosowanie coraz bardziej odpornych materiałów zapobiegających wnikaniu płomienia do środka oraz o coraz większej odporności mechanicznej. Nie bez znaczenia jest także dobór odpowiednich membran paroprzepuszczalnych oraz zastosowanie odpowiedniej bielizny podbarierowej gwarantującej lepszy odbiór potu. Stąd też w ramach projektu rozwojowego nr O ROB 001401 pt. „Nowoczesne ochrony służb ratowniczych KSRG w oparciu o potrzeby użytkowników końcowych" skupiono się na stworzeniu dwóch nowych typów ubrań specjalnych, wychodzących naprzeciw oczekiwaniom użytkowników końcowych:

- ubranie specjalne nowej generacji o maksymalnie obniżonej masie spełniające wymogi rozporządzenia MSWiA z dnia 27 kwietnia 2010 r. w sprawie wykazu wyrobów służących zapewnieniu bezpieczeństwa publicznego lub ochronie zdrowia i życia oraz mienia, a także zasad wydawania dopuszczenia tych wyrobów do użytkowania. Ubranie to oznaczono jako USNG i taka nazwa będzie stosowana w niniejszej publikacji;

- ubranie specjalne nowej generacji przeznaczone do działań w przestrzeni otwartej. Wymogi dla tego typu ubrań nie są określone w rozporządzeniu MSWiA z dnia 27 kwietnia 2010 r. Ubranie to oznaczono jako USPO i taka nazwa będzie stosowana w niniejszej publikacji. 
Ze względu na specyfikę pracy ratownika precyzyjne określenie poziomu wysiłku nie jest łatwe i wymaga zastosowania technik pomiarowych opartych na badaniu różnych parametrów organizmu człowieka takich jak zmiany częstości skurczów serca (HR), wentylacja minutowa płuc (VE), zużycie tlenu $\left(\mathrm{VM}_{\mathrm{O} 2}\right)$ czy też częstość oddechu (BF) w warunkach symulowanego obciążenia. Pewne z wymienionych parametrów organizmu takie jak HR oraz VE udało się zbadać w warunkach rzeczywistych działań ratowniczo-gaśniczych, co pozwoliło na określenie reakcji organizmu w zależności od rodzaju działającego bodźca psychofizycznego. Okazuje się bowiem, że przyczyną aż 44\% wypadków śmiertelnych wśród strażaków w USA w okresie pomiędzy 1995-2007 była nagła niewydolność serca. Poznanie zatem wpływu poszczególnych stresorów jest konieczne celem poprawy bezpieczeństwa pracy. 



\section{NotKi BIOgRAFICZNE}

dr Łukasz Apiecionek - stopień naukowy uzyskał w Instytucie Podstawowych Problemów Techniki Polskiej Akademii Nauk. Adiunkt na Uniwersytecie Kazimierza Wielkiego w Bydgoszczy w Zakładzie Informatyki Instytutu Techniki. Uczestniczył w realizacji wielu projektów B+R, które zostały w szerokim zakresie wdrożone u użytkowników.

st. bryg. mgr inż. Dariusz Czerwienko - kierownik Zespołu Laboratoriów Technicznego Wyposażenia Straży Pożarnej i Technicznych Zabezpieczeń Pożarowych CNBOP-PIB. Jest autorem i współautorem szeregu artykułów i monografii, wystąpień na konferencjach krajowych i zagranicznych.

mgr inż. Karolina Dwórska - absolwentka kierunku Technologia Chemiczna na Wydziale Chemicznym Politechniki Warszawskiej. Obecnie pracuje w Zespole Laboratoriów Technicznego Wyposażenia Straży Pożarnej i Technicznych Zabezpieczeń Przeciwpożarowych w Centrum Naukowo-Badawczym Ochrony Przeciwpożarowej - Państwowym Instytucie Badawczym.

prof. dr hab. inż. Piotr Furmański - dyrektor Instytutu Techniki Cieplnej Politechniki Warszawskiej. Jego specjalnością naukową jest radiacyjna wymiana ciepła oraz transport ciepła i masy w układach złożonych.

techn. Maciej Gloger - pracownik z 15-letnim stażem Zespołu Laboratoriów Technicznego Wyposażenia Straży Pożarnej i Technicznych Zabezpieczeń Przeciwpożarowych CNBOP-PIB, wykonawca projektów i współautor publikacji związanych z techniką pożarniczą.

mgr inż. Leszek Jurecki - pracuje w Zespole Laboratoriów Technicznego Wyposażenia Straży Pożarnej i Technicznych Zabezpieczeń Pożarowych CNBOP-PIB. Jest autorem i współautorem szeregu artykułów i monografii związanych z badaniami pojazdów pożarniczych.

st. kpt. mgr inż. Przemysław Kowalczyk - absolwent i pracownik Szkoły Głównej Służby Pożarniczej, kierownik Pracowni Bezpieczeństwa Działań Ratowniczych. Ukończył również studia podyplomowe BHP i ergonomia na Wydziale Inżynierii Produkcji Politechniki Warszawskiej. Od kilkunastu lat zajmuje się tematyką bezpieczeństwa i higieny służby. Uczestnik projektów badawczych z zakresu środków ochrony indywidualnej oraz fizjologii pracy. Aktualnie bierze udział w pracach komisji ds. zmian w umundurowaniu strażaków przy komendancie głównym PSP.

prof. dr hab. inż. Janusz Kręcikij - absolwent Wyższej Szkoły Oficerskiej Wojsk Pancernych im. Stefana Czarnieckiego w Poznaniu. Po awansie na stopień gen. bryg. w latach 2007-2009 - rektor-komendant Akademii Obrony Narodowej w Warszawie. Od roku 2010 zastępca dyrektora Instytutu Bezpieczeństwa Narodowego Wydziału Nauk o Bezpieczeństwie Krakowskiej Akademii im. A.F. Modrzewskiego. Dorobek naukowo-publicystyczny Autora liczy ponad 100 pozycji (monografii, prac naukowo-badawczych, podręczników, artykułów oraz komunikatów naukowych). W styczniu 2012 r. prezydent RP nadał mu tytuł naukowy profesora. 
prof. dr hab. inż. Izabella Krucińska - profesor nauk technicznych z dyscypliny włókiennictwo. Jej specjalizacja naukowa to struktura wyrobów włókienniczych, metrologia włókiennicza i technologia wyrobów nietkanych. Aktualnie pełni funkcję prodziekana ds. Nauki Wydziału Technologii Materiałowych i Wzornictwa Tekstyliów oraz kierownika Katedry Materiałoznawstwa, Towaroznawstwa i Metrologii Włókienniczej Politechniki Łódzkiej.

mgr inż. Bartosz Kukawka - absolwent kierunku informatyka na Politechnice Poznańskiej, specjalność inteligentne systemy wspomagania decyzji. Obecnie pracownik firmy MLabs sp. z o.o. oraz student studiów doktoranckich na Wydziale Informatyki Politechniki Poznańskiej.

dr inż. Włodzimierz Kupicz - w 2009 obronił doktorat na Wydziale Nauk Technicznych Uniwersytetu Warmińsko-Mazurskiego. Obecnie pełni funkcję kierownika Zakładu Pojazdów Kołowych Wojskowego Instytutu Techniki Pancernej i Samochodowej w Wojskowym Instytucie Techniki Pancernej i Samochodowej.

dr inż. Piotr Łapka - pracownik Zakładu Termodynamiki w Instytucie Techniki Cieplnej Politechniki Warszawskiej. Jego specjalnością naukową jest modelowanie matematyczne i numeryczne procesów cieplno-przepływowych.

dr inż. Adam Majka - adiunkt oraz kierownik Zespołu Laboratoriów Badań chemicznych i Pożarowych CNBOP-PIB. Zajmuje się prowadzeniem badań sprzętu podręcznego oraz środków gaśniczych wykorzystywanych w ochronie przeciwpożarowej. Jest autorem lub współautorem wielu artykułów, monografii i referatów prezentowanych na konferencjach krajowych i zagranicznych. Kierownik licznych projektów naukowo-badawczych.

mgr inż. Rafał Motylewski - absolwent Akademii Techniczno-Rolniczej (obecnie Uniwersytet Technologiczno-Przyrodniczy). Pracuje od 13 lat w firmie TELDAT. Uczestniczył w badaniach i testach oraz wdrażaniu kilkunastu projektów $\mathrm{B}+\mathrm{R}, \mathrm{w}$ tym finansowanych przez NCBR. Specjalista w zakresie bezpieczeństwa systemów IT.

st. kpt. dr inż. Paweł Ogrodnik - absolwent Wydziału Inżynierii Budowlanej i Sanitarnej Politechniki Lubelskiej (kierunek: budownictwo). W 2001 roku rozpoczął pracę w Zakładzie Mechaniki Stosowanej Szkoły Głównej Służby Pożarniczej. W 2006 roku obronił rozprawę doktorską na temat Wpływu temperatur występujących w czasie pożaru na przyczepność pomiędzy stalą a betonem. Autor/współautor kilkudziesięciu publikacji naukowych opublikowanych w czasopismach, a także prezentowanych na krajowych i międzynarodowych konferencjach naukowych.

mgr inż. Michał Pasieka - absolwent studiów dziennych Politechniki Poznańskiej na Wydziale Elektroniki i Telekomunikacji ukończonych w 2008 r. oraz automatyki i robotyki na wydziale elektrycznym ukończonych w 2010 r. na Politechnice Poznańskiej. Pracownik firmy MLabs sp. z o.o. oraz Politechniki Poznańskiej.

mgr inż. Łukasz Pastuszka - absolwent Wydziału Transportu Politechniki Radomskiej. Kilkuletni pracownik Zespołu Laboratoriów Technicznego Wyposażenia Straży Pożarnej 
i Technicznych Zabezpieczeń Przeciwpożarowych CNBOP-PIB, kierownik i wykonawca projektów związanych z techniką pożarniczą.

dr inż. Dorota Riegert - w roku 2012 ukończyła studia doktoranckie na Wydziale Inżynierii Materiałowej Politechniki Warszawskiej, uzyskując stopień doktora nauk technicznych. Jest autorem lub współautorem artykułów publikowanych w czasopismach naukowych i materiałach konferencyjnych, a także autorem referatów prezentowanych na konferencjach krajowych i zagranicznych. Od czerwca 2012 r. pracownik Zespołu Laboratoriów Badań Chemicznych i Pożarowych w CNBOP-PIB, gdzie zajmuje się tematyką związaną z ochroną przeciwpowodziową.

dr inż. Jacek Roguski - adiunkt w Zespole Laboratoriów Technicznego Wyposażenia Straży Pożarnej i Technicznych Zabezpieczeń Pożarowych CNBOP-PIB. Naukowo i praktycznie zajmuje się zagadnieniami ochron osobistych, instalacji gaśniczych oraz problemami eksploatacji urządzeń technicznych. Jest autorem i współautorem szeregu artykułów i monografii oraz wystąpień na konferencjach krajowych i zagranicznych.

mgr inż. Łukasz Rowicki - absolwent Wydziału Samochodów i Maszyn Roboczych Politechniki Warszawskiej. Od 2011 r. pracownik Zespołu Laboratoriów Technicznego Wyposażenia Straży Pożarnej i Technicznych Zabezpieczeń Przeciwpożarowych CNBOP-PIB.

Dawid Rzemek - student studiów inżynierskich Wyższej Szkoły Informatyki Stosowanej i Zarządzania pod auspicjami Polskiej Akademii Nauk w Warszawie na Wydziale Informatycznych Technik Zarządzania.

dr inż. Ewa Skrzetuska - pracownik Katedry Materiałoznawstwa, Towaroznawstwa i Metrologii Włókienniczej oraz laboratorium akredytowanego Lab-Tex. W 2013 r. obroniła rozprawę doktorską pt. Badania nad wytworzeniem funkcjonalnych nanomateriałów w postaci dyspersji wodnych i ich depozycja na podłoża tekstylne. Obszar jej zainteresowań związany jest $\mathrm{z}$ wytwarzaniem innowacyjnych materiałów włókienniczych oraz drukiem funkcjonalnym przy użyciu polimerów elektroprzewodzących, przeznaczonych zarówno do zastosowań technicznych, jak i ochrony zdrowia oraz życia.

dr inż. Mikołaj Sobczak - adiunkt na Wydziale Informatyki Politechniki Poznańskiej.

mgr inż. Paweł Stosik - absolwent Akademii Techniczno-Rolniczej (obecnie Uniwersytet Technologiczno-Przyrodniczy). Pracuje od 13 lat w firmie TELDAT. Uczestniczył w badaniach i testach oraz wdrażaniu kilkunastu projektów $B+R, w$ tym finansowanych przez NCBR. Specjalista w zakresie wdrażania rozwiązań dotyczących bezpieczeństwa systemów IT.

mgr inż. Zuzanna Ślosorz - w roku 2011 ukończyła studia na Wydziale Technologii Chemicznej Politechniki Poznańskiej. Pracuje w Centrum Naukowo-Badawczym Ochrony Przeciwpożarowej - PIB w Zespole Laboratoriów Badań Chemicznych i Pożarowych. Specjalność - oddziaływanie substancji gaśniczych na materiały oraz inne zjawiska elektrochemiczne. Jest autorem lub współautorem wielu artykułów, monografii i referatów prezentowanych na konferencjach krajowych i zagranicznych. 
mł. kpt. dr Tomasz Węsierski - adiunkt w Szkole Głównej Służby Pożarniczej. Jego specjalizacja to ratownictwo chemiczne oraz działania neutralizacyjne niekontrolowanych rozlewisk substancji niebezpiecznych.

dr hab. inż. Tomasz Wiśniewski, prof. nadzw. PW - kierownik Zakładu Termodynamiki w Instytucie Techniki Cieplnej Politechniki Warszawskiej. Jego specjalnością naukową jest wymiana ciepła. 
Publikacja jest efektem dyskusji nad problemami użytkowania sprzętu i wyposażenia straży pożarnej, w której wzięli udział reprezentanci różnych środowisk naukowych, organizacji i instytucji podczas konferencji pt. „Problemy monitoringu eksploatacji sprzętu i wyposażenia w straży pożarnej", która odbyła się w dniach 26-27 marca 2015 r.

w Centrum Naukowo-Badawczym Ochrony Przeciwpożarowej im. Józefa Tuliszkowskiego Państwowym Instytucie Badawczym.

Problemy eksploatacji dotyczą zarówno rozwiązań teoretycznych oraz praktycznych, jak i źródeł oraz przyczyn powstawania zagrożeń, także tych nie zawsze pozostających w bezpośrednich związkach z efektywnością działań ratowniczo-gaśniczych.

Przedstawiony materiał może być pomocny dla teoretyków i praktyków zajmujących się problematyką eksploatacji sprzętu w straży pożarnej.

ISBN 978-83-61520-22-1

DOI: $10.17381 / 2015.2$

Wydawnictwo CNBOP-PIB www.cnbop.pl

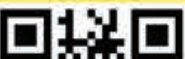

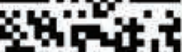

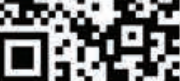

